\title{
COOPERAÇÃO JURÍDICA INTERNACIONAL EM MATÉRIA PENAL E AS MEDIDAS CAUTELARES PATRIMONIAIS
}

\author{
Mestrado EM DiReito
}

Dissertação apresentada à Banca Examinadora, no âmbito do Programa de Pós-Graduação da Faculdade de Direito da Universidade de São Paulo, como exigência parcial para a obtenção do título de Mestre em Direito, sob orientação do Professor Titular Antonio Scarance Fernandes

FACULDADE DE DIREITO DA UNIVERSIDADE DE SÃO PAULO

SÃO PAULO

2014 
Banca Examinadora 


\section{AGRADECIMENTOS}

Primeiramente, gostaria de manifestar minha profunda gratidão ao meu orientador, Professor Antonio Scarance Fernandes, que confiou no projeto de mestrado então apresentado e me deu a oportunidade de frequentar o curso de pós-graduação na Faculdade de Direito da Universidade de São Paulo. Agradeço-lhe pelos inestimáveis ensinos, sugestões e pelo constante estímulo, fundamentais para a realização do trabalho.

Da mesma forma, não poderia deixar de agradecer ao Professor Miguel Reale Júnior, de quem tenho a honra de ser colega de escritório e eterno aprendiz, pelo exemplo profissional e acadêmico, pelo imenso incentivo e pela leitura crítica da dissertação, o que me permitiu aprimorar as ideias defendidas.

Quero também agradecer à minha amada esposa, Kallana, que trilhou ao meu lado os três anos de estudos para o mestrado. Obrigado por compartilhar comigo escolhas, ideais e conquistas.

Agradeço, por fim, aos meus familiares e amigos, pelas acolhedoras palavras de apoio e pela compreensão em razão das inúmeras horas de convivência que lhes foram tiradas. 


\section{RESUMO}

No momento em que se mostrou difícil reprimir o crime no âmbito interno dos países, a comunidade internacional passou a perseguir, também, os efeitos e proventos do crime, através do cumprimento de medidas cautelares patrimoniais para bloqueio e confisco de bens do acusado existentes no exterior. Tal intento foi atingido por meio da cooperação jurídica internacional, cujos instrumentos estão sujeitos ao due process of law. Contudo, por haver distintos sistemas processuais, o estranhamento do tratamento dispensado pelo ordenamento jurídico de um Estado em determinada matéria de Direito Processual Penal pode deflagrar, perante outro Estado, argumentos contrários ao atendimento do pedido de assistência jurídica, inviabilizando o fluxo cooperacional. Por isso, várias questões surgem quando se desloca as medidas cautelares patrimoniais penais no contexto da cooperação jurídica. A presente dissertação abordará o tema da cooperação jurídica internacional em matéria penal sob a perspectiva do devido processo legal e, a partir desse enfoque, identificará conflitos que eventualmente surgem dos pedidos de assistência jurídica para cumprimento de medidas cautelares patrimoniais.

Palavras-chave: Cooperação Jurídica Internacional - Processo Penal - Processo Penal Internacional - Medidas Cautelares Patrimoniais. 


\begin{abstract}
Once it became difficult to restrain crime under domestic jurisdiction, international communities also started to go after the proceeds and instrumentalities of offenses, through enforcement of provisional measures, aiming at immobilization and forfeiture of defendant's assets existing abroad. Said target was achieved by legal international cooperation, whose instruments are subject to the due process of law. However, as there are different procedure systems, the strangeness caused by treatment offered by the legal system of a State in a certain matter of Criminal Procedure Law may deflagrate before another State, opposite arguments to fulfillment of legal assistance order, making unfeasible the cooperation flow. That is why several issues come up when criminal provisional measures are moved in the context of legal cooperation. The current dissertation will discuss the international legal cooperation in criminal matter under the light of due process of law and thereinafter, it will identify conflicts that may eventually appear from orders of legal assistance for the enforcement of provisional measures.
\end{abstract}

Keywords: International Legal Cooperation - Criminal Procedure - International Criminal Procedure - Provisional Measures. 


\section{SUMÁRIO}

INTRODUÇÃO

I. EFICIÊNCIA E GARANTISMO NA COOPERAÇÃo JURÍDICA

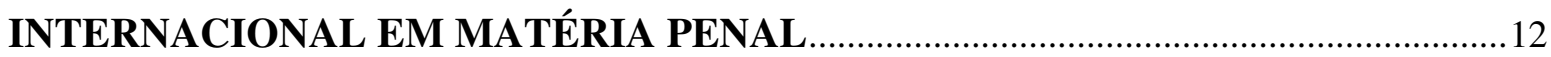

1.1. Introdução à cooperação jurídica internacional em matéria penal...................................................12

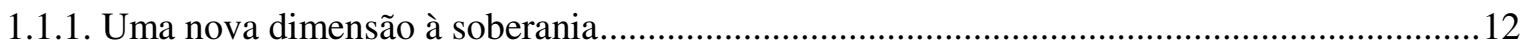

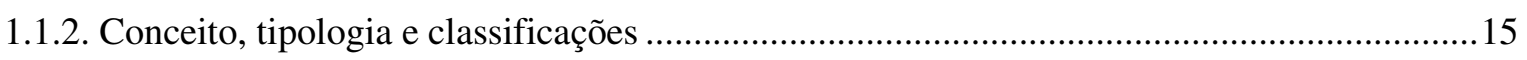

1.2. A cooperação jurídica internacional vista como processo ..............................................................19

1.3. A concepção trilateral da cooperação jurídica internacional ..........................................................22

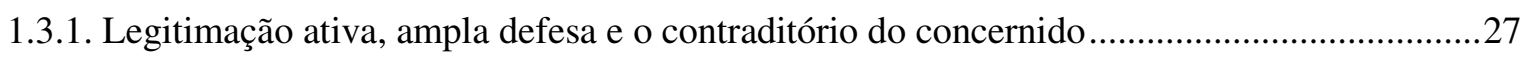

1.4. Cooperação jurídica e o Direito Processual Penal Internacional .....................................................29

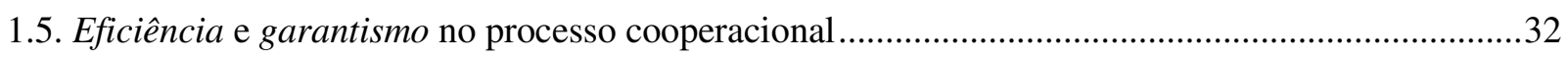

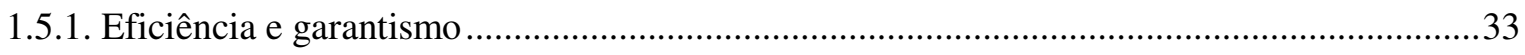

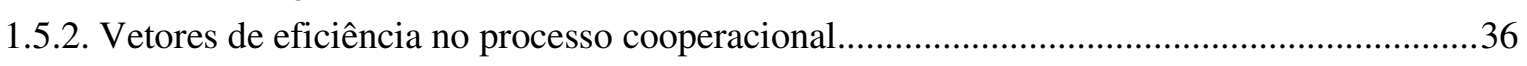

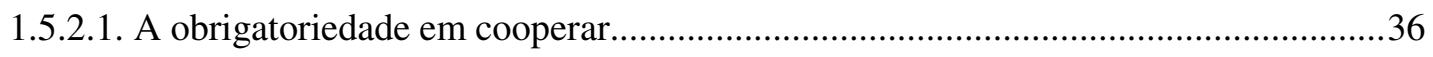

1.5.2.2. A evolução do paradigma do soberanismo ao da mútua confiança .............................38

1.5.3. Vetores de garantismo no processo cooperacional ..............................................................42

1.5.3.1. As normas processuais penais de garantia previstas em Tratados e Convenções

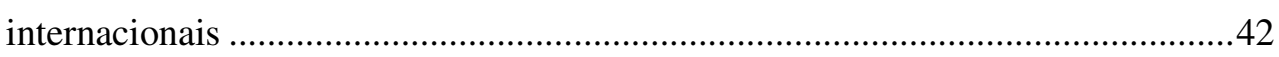

1.5.3.2. Ius cogens e a internacionalização dos direitos humanos ...........................................46

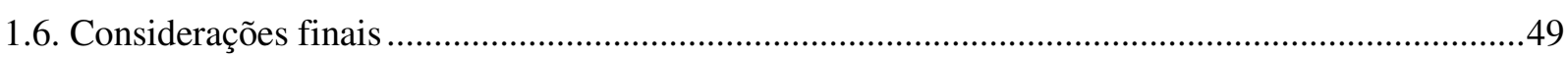

II. MEDIDAS CAUTELARES PATRIMONIAIS NO PROCESSO PENAL ..........................51

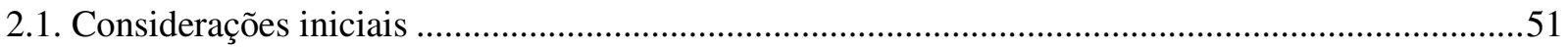

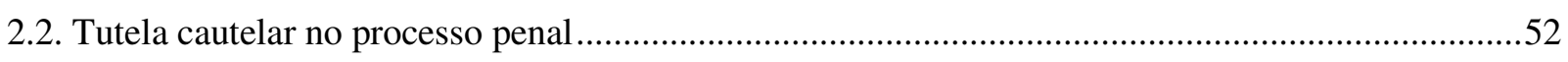

2.3. Medidas cautelares patrimoniais no processo penal ..................................................................55

2.3.1. Finalidades das medidas cautelares patrimoniais no processo penal ....................................57

2.3.1.1. Assegurar a reparação do dano causado pelo delito ................................................59

2.3.1.2. Assegurar a perda do produto ou provento do crime ...............................................62

2.3.2. Características das medidas cautelaras patrimoniais no processo penal ..................................64

2.3.3. Pressupostos das medidas cautelares patrimoniais no processo penal ....................................68

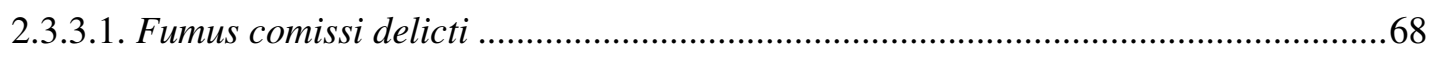

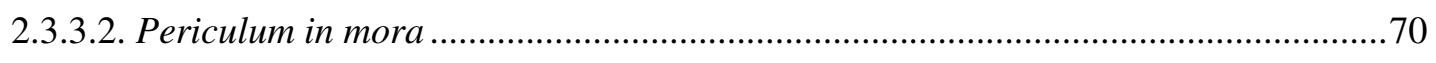

2.4. Medidas cautelares patrimoniais penais no direito brasileiro e comparado.....................................73

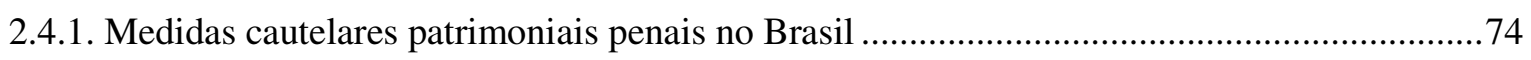

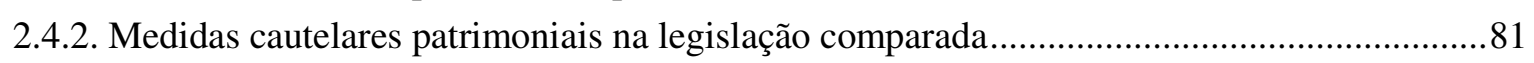

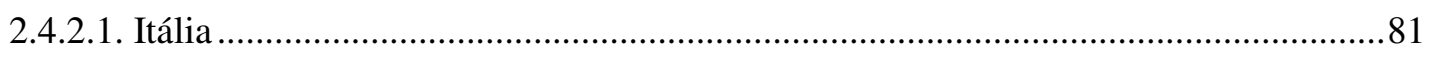

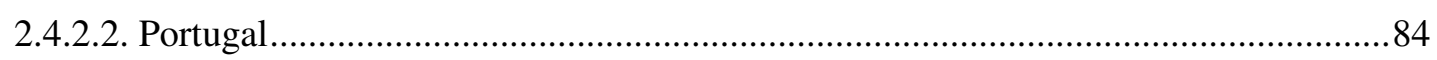

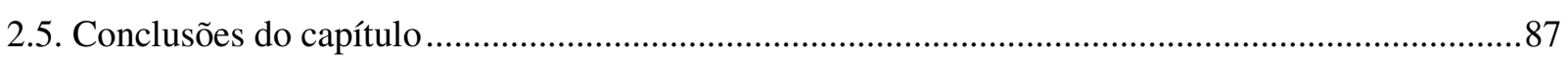


III. MEDIDAS CAUTELARES PATRIMONIAIS PENAIS NO CONTEXTO DA COOPERAÇÃO JURÍDICA INTERNACIONAL

3.1. A contextualização das medidas cautelares patrimoniais ao tema da cooperação jurídica

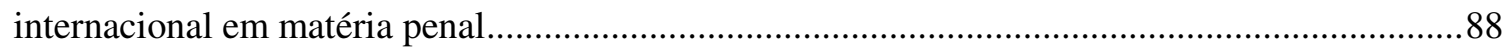

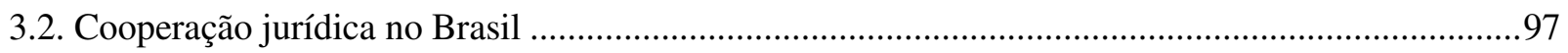

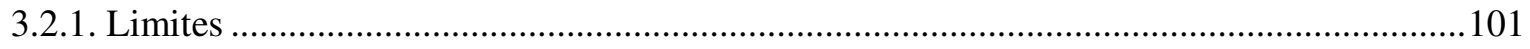

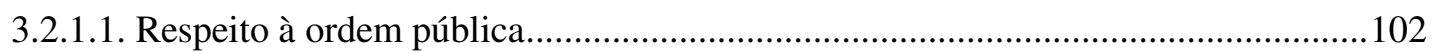

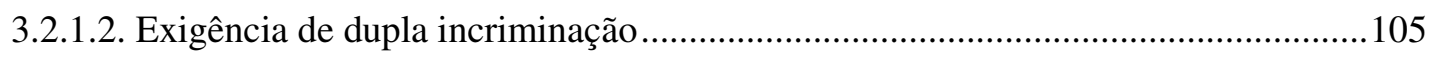

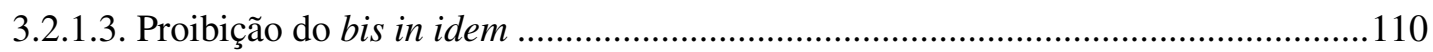

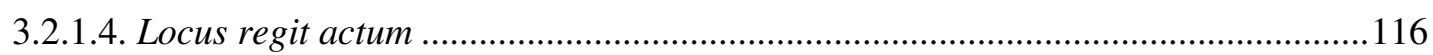

3.2.2. Instrumentos de cooperação jurídica internacional usados às medidas cautelares

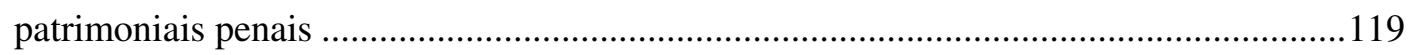

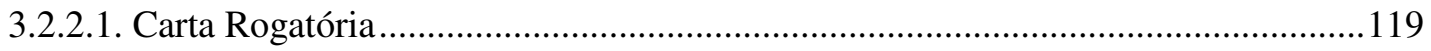

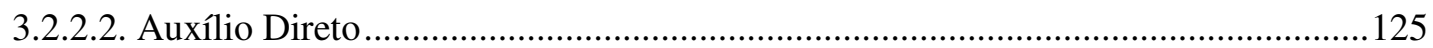

3.3. O conflito entre as opções de processo penal: dificuldade no atendimento de medidas cautelares patrimoniais em cooperação jurídica no Brasil ........................................................128

\section{MEDIDAS CAUTELARES PATRIMONIAIS EM COOPERAÇÃO JURÍDICA}

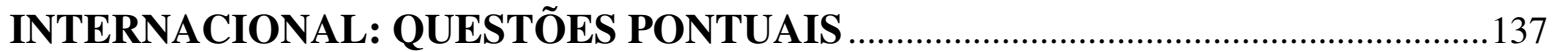

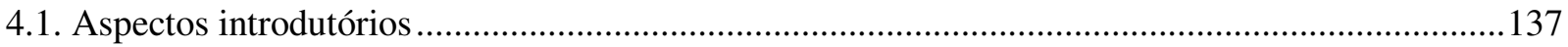

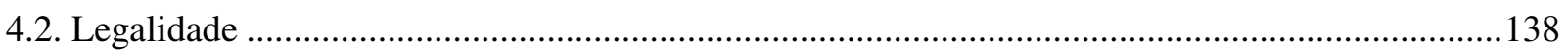

4.2.1. Autonomia do processo cautelar e o processo estrangeiro..................................................138

4.2.2. Referibilidade das medidas cautelares patrimoniais em cooperação jurídica internacional e o princípio da dupla incriminação ............................................................... 140

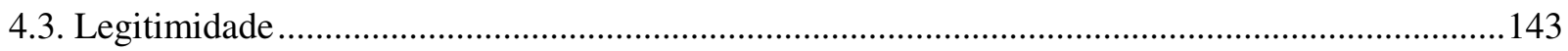

4.3.1. Legitimidade ativa para requerer assistência jurídica internacional ....................................144

4.3.2. Legitimidade ativa para requerer a tutela cautelar patrimonial solicitada em assistência

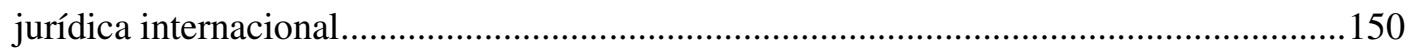

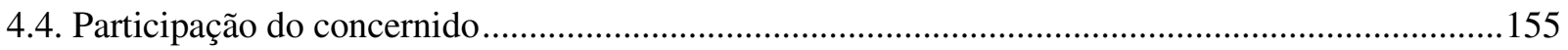

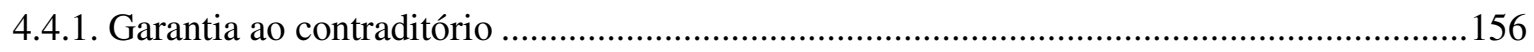

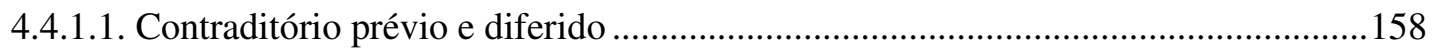

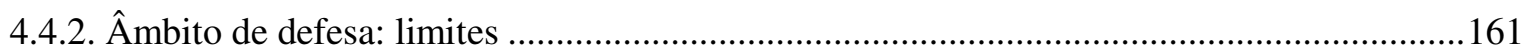

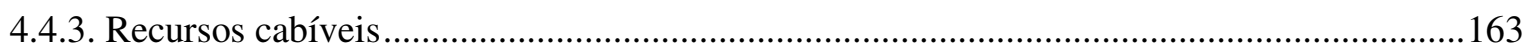

CONCLUSÕES

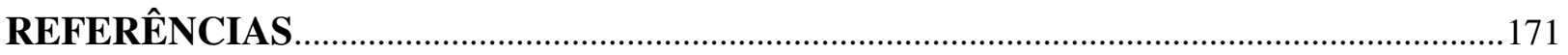




\section{INTRODUÇÃO}

A proposta da presente dissertação é abordar o tema da cooperação jurídica internacional em matéria penal sob a perspectiva do devido processo legal, e, a partir desse enfoque, estudar conflitos que eventualmente surgem a partir dos pedidos de assistência jurídica para o cumprimento de medidas cautelares patrimoniais penais.

A globalização trouxe a internacionalização do Direito e também do crime, pois os delitos passaram a ter efeitos em outros Estados. Uma vez que se mostrou difícil reprimir o crime no âmbito interno, o esforço da comunidade internacional voltou-se também à perseguição dos efeitos e proventos do crime, como forma de reprimir a criminalidade transnacional.

No intuito de estrangular essa criminalidade transnacional, tratados e convenções internacionais passaram a aproximar cada vez mais os Estados, com o objetivo de oferecer auxílio mútuo para identificação e bloqueio de bens.

Por essa razão, demandas de cooperação surgem hoje corriqueiramente, e o estreitamento das relações internacionais permite aos Estados identificar valores cada vez mais comuns. Frente à diversidade dos sistemas jurídicos, o processo de formação, desenvolvimento e consolidação dos direitos humanos estabeleceu standards mínimos de conduta, que podem servir como hábeis ferramentas de aproximação entre os sistemas, visando a tutelar bens jurídicos supranacionais e universais ${ }^{1}$.

Existem, contudo, situações nas quais desponta uma latente tensão na cooperação jurídica internacional em matéria penal. Isto decorre das diferentes opções de direito penal e de direito processual penal entre os Estados envolvidos na cooperação, o chamado Estado requerente (o país emissor do pedido de assistência) e o Estado requerido (o país que deve prestar a assistência demandada) ${ }^{2}$.

Existindo distintas opções, o estranhamento do tratamento dispensado pelo ordenamento jurídico do Estado requerente de determinada matéria de direito processual

\footnotetext{
${ }^{1}$ Cf. BECHARA, Fábio Ramazzini. Cooperação jurídica internacional em matéria penal: eficácia da prova produzida no exterior. São Paulo: Saraiva, 2011.

2 ABADE, Denise Neves. Direitos fundamentais na cooperação jurídica internacional: extradição, assistência jurídica, execução de sentença estrangeira e transferência de presos. São Paulo: Saraiva, 2013. p. 22.
} 
penal pode deflagrar, perante os órgãos do Poder Judiciário do Estado requerido, argumentos contrários ao atendimento do pedido de assistência jurídica penal, inviabilizando o fluxo cooperacional.

A tensão entre os diferentes sistemas jurídicos ainda hoje dificulta o cumprimento de medidas cautelares patrimoniais no âmbito da assistência jurídica em matéria penal. As demandas brasileiras cumpridas no exterior superam o número de demandas atendidas pelo país, segundo dados oficiais divulgados pelo Ministério da Justiça $^{3}$. A impermeabilidade dos Tribunais Superiores brasileiros frente aos pedidos de assistência jurídica é apontada pela doutrina como uma espécie de "xenofobia judiciária"4 .

Por outro lado, a cooperação jurídica internacional tem sido tratada nos últimos anos em nível meramente bilateral, no interesse restrito de Estados soberanos, rebaixando o acusado, processado ou condenado a mero espectador da medida constritiva que o atingirá. Na experiência dos Tribunais, muitos pedidos de assistência judiciária internacional são recebidos, processados e devolvidos ao Estado requerido sem notícia da participação da pessoa cujos direitos e garantias restaram atingidos com a diligência solicitada.

O cumprimento inaudita altera pars do pedido de assistência internacional é prática comum, principalmente em relação às medidas cautelares patrimoniais, dado pelo temor de que o conhecimento prévio pela pessoa atingida venha a frustrar a eficácia da diligência.

$\mathrm{Na}$ dissertação, adotaremos a premissa de que os pedidos de assistência jurídica em matéria penal se desenrolam através de verdadeiros processos, os chamados

\footnotetext{
${ }^{3}$ Cartilha divulgada pelo Departamento de Recuperação de Ativos e Cooperação Jurídica Internacional - DCI do Ministério da Justiça, que funciona como Autoridade Central brasileira, noticia que o Brasil é um país predominantemente requerente, ou seja, demandamos mais do que somos demandados. No período de 2004 ao primeiro semestre de 2011, os pedidos de cooperação ativa (em que o Brasil é demandante) corresponderam a $84 \%$ do fluxo cooperacional. Fonte: MINISTÉRIO DA JUSTIÇA. Disponível em: $<$ http://portal.mj.gov.br >. Acesso em: 05 jul. 2013.

${ }^{4}$ Por desconfiar-se do sistema jurídico estrangeiro, dificulta-se, sem motivo razoável, a cooperação jurídica internacional em matéria penal. Tal conduta só "estimula um ciclo vicioso de negação de cooperação, pois o Estado estrangeiro, em nome da reciprocidade diplomática, também provavelmente dificultaria a consecução de pedidos brasileiros. Ou seja, o temor ao 'estrangeiro' é um boomerang, e a 'xenofobia judiciária' é doença altamente contagiosa” (ABADE, Denise Neves. Direitos fundamentais na cooperação jurídica internacional: extradição, assistência jurídica, execução de sentença estrangeira e transferência de presos, cit., p. 333). O termo "xenofobia judiciária" também é mencionado por Antenor Madruga (O Brasil e a jurisprudência do STF na Idade Média da cooperação jurídica internacional. In: MACHADO, Maíra Rocha; REFINETTI, Domingos Fernando (Orgs.). Lavagem de dinheiro e recuperação de ativos: Brasil, Nigéria, Reino Unido e Suíça. São Paulo: Quartier Latin, 2006. p. 82).
} 
processos cooperacionais ${ }^{5}$. Nestes, devem ser reconhecidos como partes integrantes da relação processual, não somente os Estados requerente e requerido, mas também a pessoa atingida pela medida solicitada em assistência internacional. Assim, os direitos fundamentais da pessoa incidem - ou pelo menos deveriam incidir - no processo cooperacional, da mesma maneira como incidem nos processos internos dos países.

Adotada tal premissa e identificados os possíveis conflitos nos pedidos de medida cautelar patrimonial em cooperação jurídica penal, estudaremos se, através das garantias fundamentais internacionalmente reconhecidas, seria possível amenizar o choque entre os sistemas estrangeiros e estabelecer um padrão mínimo procedimental, garantindo eficiência aos pedidos de cooperação jurídica internacional, mas sem desprezo das garantias processuais da pessoa atingida.

Importante destacar desde já: o objetivo principal da dissertação é abordar o tema da cooperação jurídica internacional em matéria penal sob a perspectiva do devido processo legal - e, a partir desse foco, estudar possíveis conflitos. Para tal propósito, a fim de delimitar o tema, voltaremos as discussões ao contexto das medidas cautelares patrimoniais cumpridas em cooperação internacional, mas sem a pretensão de aprofundar o estudo das medidas cautelares no processo penal.

A dissertação está estruturada em cinco capítulos.

No primeiro capítulo, trataremos da cooperação jurídica internacional como processo no qual deve-se encontrar meios de atingir um equilíbrio entre as garantias fundamentais da pessoa atingida e o compromisso por maior efetividade no atendimento dos pedidos de assistência jurídica internacional. Para tanto, serão analisados os principais vetores que operam nos campos normativo e doutrinário no sentido de conduzir a cooperação jurídica, de um lado, a uma maior eficiência e, de outro lado, à satisfação das garantias fundamentais da pessoa humana ${ }^{6}$.

No segundo capítulo, trataremos das medidas cautelares patrimoniais no processo penal. O foco estará mais voltado ao sistema brasileiro de tutela cautelar penal, porque seria inviável expormos todas opções disponíveis na legislação comparada. Mas,

\footnotetext{
${ }^{5}$ ABADE, Denise Neves. Direitos fundamentais na cooperação jurídica internacional: extradição, assistência jurídica, execução de sentença estrangeira e transferência de presos, cit., p. 23.

${ }^{6}$ Importante ponderar que na presente dissertação adotaremos a premissa de que eficiência e garantismo são conceitos que não se contrapõe, mas, ao contrário, completam-se mutuamente, sendo certo que não há eficiência sem garantismo.
} 
restringir a pesquisa apenas ao contexto brasileiro também não se mostraria producente: remanescendo a gênese do problema - o choque ocorrido na cooperação entre diferentes sistemas jurídicos estrangeiros -, os conflitos tenderiam a ser os mesmos.

Daí surge a necessidade de estudarmos eventuais pontos de convergência e colidência do sistema jurídico brasileiro em relação a outros dois sistemas estrangeiros, selecionados a título exemplificativo entre os países dos quais o Brasil mais demanda em matéria de cooperação jurídica internacional: Itália e Portugal. A partir dessa análise, abriremos caminho para as discussões que serão desenvolvidas nos capítulos seguintes.

No terceiro capítulo, contextualizaremos as medidas cautelares patrimoniais no cenário da cooperação jurídica internacional. Serão trazidos aspectos que entendemos mais relevantes sobre cooperação jurídica internacional strictu sensu em matéria penal no Brasil: classificações, natureza jurídica, limites e instrumentos. Ademais, será demonstrado que grande parte dos entraves à maior eficiência no atendimento de pedidos de assistência pelo Brasil advém do contraponto entre as diferentes opções de direito processual penal.

Por fim, no quarto capítulo, cuidaremos das medidas cautelares patrimoniais cumpridas na cooperação strictu sensu, através dos instrumentos da carta rogatória e do auxílio direto. Nestes capítulos finais, de acordo com os temas legalidade, legitimidade e participação da pessoa atingida, serão selecionadas questões controversas para as quais, balizadas em eficiência e garantismo, buscar-se-á um padrão mínimo procedimental. 


\section{EFICIÊNCIA E GARANTISMO NA COOPERAÇÃO JURÍDICA INTERNACIONAL EM MATÉRIA PENAL}

\subsection{Introdução à cooperação jurídica internacional em matéria penal}

\subsubsection{Uma nova dimensão à soberania}

De acordo com a teoria clássica de soberania, caberia ao Estado perseguir, pelos meios necessários, a execução da política externa que lhe assegurasse a proteção de seus interesses e dos interesses de seus cidadãos, reafirmando-se perante os demais Estados.

Esse conceito westfaliano de soberania $^{7}$ colocava os Estados em constante estado de desconfiança e hostilidade entre si e estimulava políticas internas e externas, inclusive bélicas, para reafirmação de suas soberanias nacionais.

Como consequência, até a eclosão da Primeira Guerra Mundial, a segurança internacional era precária e dirigida pelos países mais poderosos ${ }^{8}$. O preceito de igualdade

\footnotetext{
${ }^{7} \mathrm{O}$ conceito que se guarda hoje de soberania foi formalmente instituído e reconhecido pela primeira vez em virtude da Paz de Westphalia, em outubro de 1648, sintetizada como o conjunto de acordos entre católicos e protestantes que colocaram fim à hegemonia do controle da igreja sobre a diplomacia medieval. Importante observação traz LEWANDOWSKI, no sentido de que "a noção de soberania, como um poder incontrastável dos governantes, não surgiu com a Paz de Westphalia, embora tenha ficado formalmente estabelecido nesta o princípio rex est imperator in regno suo, segundo o qual o rei em seu domínio não está sujeito à vontade política de quem quer que seja". (Globalização, regionalização e soberania. São Paulo: Juarez de Oliveira, 2003. p. 271). OsCAR VIlHENA VIEIRA e José Francisco SiEber LuZ FILhO, semelhantemente, defendem o estabelecimento institucional do Estado soberano com o acordo de Westphalia: "O estado soberano, no que se refere à sua compreensão pelas teorias das relações internacionais, surge em 1648, com a Paz de Westphalia..." (Soberania e direitos humanos: reflexos do caso Pinochet I. Revista do ILANUD, São Paulo, n. 17, p. 73, 2001). É a lição, ainda, de HEE MoON JO e MARCELO DA SilVA SOBRINHO: “...A Paz de Vestfália estabeleceu um sistema internacional baseado na pluralidade de Estados independentes e iguais". Segundo os autores, o marco de tal evento histórico para o direito internacional deu-se, sobretudo, porque "legitimou o poder externo que estava além do território soberano, reconhecendo-se, assim, o princípio de soberania territorial". (Soberania no direito internacional: evolução ou revolução? Revista de Estudos Jurídicos UNESP, Franca, v. 9, n. 13, p. 264, jan./dez. 2004).

${ }^{8}$ HeE Moon Jo e MARCElo dA Silva Sobrinho destacam que o sistema de Westphalia começou a ser criticado dentro e fora da Europa, em particular com o crescimento quantitativo e qualitativo dos países não-europeus. O sistema de Westphalia criou uma política de superioridade e dominação da soberania dos países europeus em detrimento dos países não-europeus, particularmente dos asiáticos, propiciando o desenvolvimento de um cenário propício à colonização no século XIX. Isso porque os países europeus fincaram suas relações internacionais com base em seu próprio interesse, ao passo que a maioria dos países orientais, por outro lado, segundo os autores, não havia consolidado uma noção de soberania. Além de que, a noção de soberania estava diretamente ligada à força de defesa, de sorte que eram considerados "não soberanos" ou "menos soberanos" os países que não possuíssem uma capacidade real de defesa. Tal quadro deu força ao surgimento de um "direito internacional europeu", que era escolhido e imposto, uma vez tido como "superior" a todos os outros. (Soberania no direito internacional: evolução ou revolução?, cit., p. 264).
} 
soberana entre os Estados somente se aplicava aos países que detinham uma efetiva força de autodefesa (levando-se em conta que o uso da força era legalizado ${ }^{9}$ ).

Assim, a busca, pelos Estados, da defesa de seus próprios interesses soberanos levou a humanidade às duas guerras mundiais, que dizimaram milhares de pessoas.

A sociedade do pós-guerra, atordoada pelas atrocidades perpetradas nos dois conflitos mundiais, chegou à convicção de que existiam direitos e garantias fundamentais inerentes a qualquer ser-humano, e que a tutela desses direitos deveria ser universal, pois os Estados, isolados em sua soberania, não seriam capazes, sozinhos, de garantir a paz e a segurança de seus cidadãos ${ }^{10}$.

Instaurou-se, dessa maneira, na sociedade do pós-guerra, o compromisso de desenvolver mecanismos eficientes de proteção, em nível global - e não apenas nos limites de cada Estado -, aos direitos humanos a todo o cidadão do mundo, como maneira de manter a paz e a ordem internacionais ${ }^{11}$.

A esse respeito, Flávia PIOvESAN ensina que, passadas as duas grandes guerras mundiais, no período em que se mostrou o limite inelástico da crueldade e do desrespeito ao valor da pessoa humana, os direitos humanos passaram a ser redesenhados “como paradigma e referencial ético a orientar a ordem internacional contemporânea" 12 . A própria ideia proclamada na Declaração Universal dos Diretos Humanos de 1948 - de ser aplicável a todas as pessoas de todos os países - disseminou a consciência em favor da internacionalização dos direitos humanos e do indivíduo como cidadão do mundo ${ }^{13}$.

É nesse sentido que explana PAUlo BARBosa CASElla: o processo de internacionalização dos direitos humanos “ocorreu na medida em que a humanidade se deu conta da necessidade desse arcabouço institucional e normativo, para regular problemas de dimensão mundial e de caráter vital, para a sobrevivência da humanidade" ${ }^{14}$.

\footnotetext{
${ }^{9}$ JO, Hee Moon; SILVA SOBRINHO, Marcelo da. Soberania no direito internacional: evolução ou revolução?, cit., p. 257.

${ }^{10}$ RITTA, Cristiano Ribeiro. Aspectos da competência jurisdicional penal internacional. Prismas: direito, políticas públicas e mundialização. Brasília, v. 3, n.1, p. 125-147, jan./jun. 2006.

${ }^{11}$ STEINER, Sylvia Helena de Figueiredo. A Convenção Americana sobre Direitos Humanos e sua integração ao processo penal brasileiro. São Paulo: Ed. Revista dos Tribunais, 2000. p. 33.

${ }^{12}$ PIOVESAN, Flavia. Direitos humanos e o direito constitucional internacional. 5. ed. São Paulo: Max Limonad, 2002. p. 131 - 132.

${ }^{13}$ PIOVESAN, Flavia. Direitos humanos e o direito constitucional internacional, cit., p. 146.

${ }^{14}$ CASELLA, Paulo Borba. Direito internacional pós-moderno. 2006. p. 75. Tese (Titular) - Faculdade de Direito da Universidade de São Paulo, São Paulo, 2006.
} 
O fortalecimento do sistema internacional de direitos humanos mostrou-se, portanto, como um marcante divisor de águas na política internacional, na medida em que se impôs em contraponto ao tradicional conceito de soberania ${ }^{15}$. A observância dos direitos humanos deixou de ser tratada como matéria de interesse particular do Estado e, portanto, vinculada à jurisdição doméstica.

Como consequência da internacionalização dos direitos humanos, o poder dos Estados entrou em processo de retraimento ${ }^{16}$.

Segundo MÁRIO LÚCIO QUINTÃo SOARES, a comunidade internacional vive em um processo de transição, em que se pressupõe um encontro harmônico entre o princípio da autodeterminação dos povos, baseado na soberania, e a nova ordem jurídica e econômica mundial ${ }^{17}$.

Trata-se da concepção compartilhada por RENATA RosSINI FASANO, quando analisa o fenômeno chamado por ela de "erosão da soberania". Tal fato é constatado na medida em que o cenário internacional vivencia um momento de transição entre a concepção westfaliana e a concepção que vislumbra o cenário internacional como uma comunidade que compartilha valores comuns, relacionados à proteção dos direitos humanos $^{18}$.

Consequentemente, embora ainda existam entraves a serem superados, a soberania tende a se tornar mais relacional que insular, representada pela capacidade do Estado soberano de participar dos regimes internacionais de cooperação, no interesse de

\footnotetext{
${ }^{15}$ VIEIRA, Oscar Vilhena; LUZ FILHO, José Francisco Sieber. Soberania e direitos humanos: reflexos do caso Pinochet I, cit., p. 77.

${ }^{16}$ Em relação à internacionalização dos direitos humanos e a crise do conceito de soberania, v. CRUZ, Paulo Márcio. Soberania, Estado, globalização e crise. Novos Estudos Jurídicos, São Paulo, ano 3, n. 15, p. 7-24, dez. 2002. Também nesse sentido, MiguEL REALE JÚNIOR afirma: "a globalização econômica e cultural deve trazer um benefício, qual seja a globalização dos direitos humanos, razão pela qual o conceito de soberania há de ser revisto, tal como formulado desde a Idade Moderna, pois a proteção dos direitos humanos por toda a comunidade internacional é uma forma de concretização do princípio do Estado Democrático, ou seja, a dignidade da pessoa humana" (Instituições de direito penal: parte geral. 3. ed. Rio de Janeiro: Forense, 2009. p. 119-120).

17 "Graças à internacionalização dos direitos humanos, a comunidade internacional vive processo de transição, apresentando o Direito Comunitário como instrumento de possível compatibilização entre o princípio de autodeterminação dos povos, enquanto princípio de independência política e de compromisso democrático, e a nova ordem jurídica e econômica internacional". (SOARES, Mário Lúcio Quintão. Mercosul, direitos humanos, globalização e soberania. 2. ed. Belo Horizonte: Del Rey, 1999. p. 95). No mesmo sentido, defendem JosÉ ANTONIO DiAS TOFFOLI e VIRGínIA CHARPINEI JUNGER CESTARI que a noção básica do direito internacional moderno é de um "direito intergovernamental, de coordenação" (Mecanismos da cooperação jurídica internacional no Brasil. In: MANUAL de cooperação jurídica internacional e recuperação de ativos: cooperação em matéria penal. Brasília: Ministério da Justiça, 2008. p. 22).

${ }^{18}$ FASANO, Renata Rossini. A competência repressiva universal no direito internacional penal. 2011. Dissertação (Mestrado) - Faculdade de Direito da Universidade de São Paulo, São Paulo, 2011.
} 
bem comum supranacional, universal ${ }^{19}$. Por meio da cooperação jurídica internacional é que os países passaram a exercer sua soberania e a portar-se como players globais.

Antes do processo de retraimento da soberania, o auxílio internacional ocorria esporadicamente, como fruto de mera cordialidade. Os pedidos de auxílio eram vistos como "intromissão" de um Estado estrangeiro em outro. A resistência que impedia maior fluxo de pleitos cooperacionais foi sendo superada conjuntamente com a crise da visão da soberania como um valor absoluto.

Portanto, a dimensão que hoje tem sido restabelecida à soberania nacional se mostrou relevante ao desenvolvimento da cooperação jurídica internacional.

Por reflexo da globalização, houve um processo de internacionalização dos delitos. Por isso, os países passaram a reconhecer a existência de uma justiça universal, que não estaria adstrita aos limites territoriais dos Estados, mas seria resultado do direito a uma segurança jurídica universal contra a criminalidade transnacional. Nesse contexto, não resiste mais a ideia do auxílio internacional como mera cortesia.

A flexibilização do conceito de soberania, associada ao crescimento dos crimes transnacionais trouxe a consciência sobre a necessidade de novas modalidades de cooperação, mais ágeis e eficientes. A tradicional desconfiança das decisões provenientes de autoridades estrangerias tem cedido frente a novas modalidades diretas e menos burocráticas de cooperação jurídica internacional.

\subsubsection{Conceito, tipologia e classificações}

Cooperação jurídica internacional em matéria penal pressupõe, grosso modo, compromisso de assistência mútua - colaboração - entre diferentes Estados soberanos ou entre Estados e organismos ou tribunais internacionais e supranacionais, para a consecução de medidas, atos ou providências de natureza processual, extraprocessual (administrativa)

\footnotetext{
${ }^{19}$ SLAUGHTER, Anne-Marie. Sovereighty and power in a networked world order. Stanford Journal of International Law, v. 40, p. 283-327, 2004. Semelhante posicionamento se extrai dos estudos de MIREILLE DELMAS-MARTY. Dispões a autora que a mundialização atual, caracterizada por novas tecnologias que tornam mais fácil a circulação de mercadorias, capital e de informações culturais, "reforça a interdependência e enfraquece os Estados e os seus sistemas de Direito" (O direito penal como ética da mundialização. Revista Portuguesa de Ciência Criminal, Coimbra, ano 14, n. 3, p. 287, jul./set. 2004).
} 
ou investigativa penal, a serem cumpridas por órgãos competentes no âmbito de uma jurisdição, no interesse de jurisdição estrangeira ${ }^{20}$.

Embora seja possível encontrar outros termos ${ }^{21}$, o mais consagrado na língua portuguesa é "cooperação jurídica internacional”, 22 que também adotaremos na presente dissertação.

\footnotetext{
${ }^{20}$ Para NÁDIA DE ARAÚJO, “Cooperação Jurídica Internacional, que é terminologia consagrada, significa, em sentido amplo, o intercâmbio internacional para o cumprimento extraterritorial de medidas processuais do Poder Judiciário de outro Estado". (ARAÚJO, Nádia de (Coord.). Cooperação jurídica internacional no Superior Tribunal de Justiça: comentários à Resolução $\mathrm{n}^{\circ}$ 9/2005. Rio de Janeiro: Renovar, 2010. p. 2). "Cooperação pressupõe trabalho conjunto, colaboração. É nesse sentido que toda e qualquer forma de colaboração entre Estados, para a consecução de um objetivo comum, que tenha reflexos jurídicos, denomina-se cooperação jurídica internacional" (TOFFOLI, José Antonio Dias; CESTARI, Virgínia Charpinei Junger. Mecanismos da cooperação jurídica internacional no Brasil, cit., p. 23). Preferindo a expressão "cooperação Judicial Internacional", RAúl CERVINI e JUAREZ TAVARES definem como o "conjunto de atividades processuais (cuja proteção não se esgota na simples forma), regulares (normais), concretas e de diverso nível, cumpridas por órgãos jurisdicionais (competentes) em matéria penal, pertencentes a distintos Estados soberanos, que convergem em nível internacional (funcional necessariamente), na realização de um mesmo fim, que não é senão o desenvolvimento (preparação e consecução) de um processo (principal) da mesma natureza (penal), dentro de um estrito marco de garantias, conforme o diverso grau e projeção intrínseco do auxílio requerido" (Princípios da cooperação judicial penal internacional no Protocolo do Mercosul. São Paulo: Ed. Revista dos Tribunais, 2000. p. 51). "A cooperação jurídica internacional em matéria penal consiste no conjunto de medidas e mecanismos pelos quais órgãos competentes dos Estados solicitam e prestam auxílio recíproco para realizar, em seu território, atos pré-processuais ou processuais que interessam à jurisdição estrangeira na esfera criminal" (ABADE, Denise Neves. Direitos fundamentais na cooperação jurídica internacional: extradição, assistência jurídica, execução de sentença estrangeira e transferência de presos, cit., p. 27).

${ }^{21}$ LUIZ FABRICIO THAUMATURGO VERGUEIRO cita outras expressões usadas pela doutrina, como "cooperação judicial internacional", "auxílio judicial internacional" e "cooperação interjurisdicional" (Implementação da cooperação jurídica internacional vertical. 2012. Tese (Doutorado) - Faculdade de Direito da Universidade de São Paulo, São Paulo, 2012. p. 354-355). DENISE NEVES ABADE acrescenta, ainda, os termos "cooperação jurisdicional internacional" e "cooperação judiciária internacional" (Direitos fundamentais na cooperação jurídica internacional: extradição, assistência jurídica, execução de sentença estrangeira e transferência de presos, cit., p. 28-29).

${ }^{22}$ Como se vê, v. g., ABADE, Denise Neves. Direitos fundamentais na cooperação jurídica internacional: extradição, assistência jurídica, execução de sentença estrangeira e transferência de presos, cit.; SOUZA, Carolina Yumi de. Cooperação jurídica internacional em matéria penal: considerações práticas. Revista Brasileira de Ciências Criminais, São Paulo, v. 16, n. 71, p. 300, mar./abr. 2008; ARAS, Vladmir. O papel da autoridade central nos acordos de cooperação penal internacional. In: BALTAZAR JÚNIOR, Paulo José; LIMA, Luciano Flores de (Orgs.). Cooperação jurídica internacional em matéria penal. Porto Alegre: Verbo Jurídico, 2010; MORO, Sérgio Fernando. Cooperação jurídica internacional em casos criminais: considerações gerais. In: BALTAZAR JÚNIOR, Paulo José; LIMA, Luciano Flores de (Orgs.). Cooperação jurídica internacional em matéria penal. Porto Alegre: Verbo Jurídico, 2010; CORDANI, Dora Cavalcanti. A cooperação jurídica Internacional em matéria penal no Brasil: as cartas rogatórias e o auxílio direto - controle dos atos pela parte atingida. In: VILARDI, Celso Sanchez; PEREIRA, Flávia Rahal Bresser; DIAS NETO, Theodomiro (Coords.). Direito penal econômico: crimes econômicos e processo penal. São Paulo: Saraiva, 2008; VERGUEIRO, Luiz Fabricio Thaumaturgo. Implementação da cooperação jurídica internacional vertical, cit.; VILARES, Fernanda Regina. Cooperação internacional em matéria penal e a recuperação de ativos. In: FERNANDES, Antonio Scarance; ZILLI, Marcos Alexandre Coelho (Coord.). Direito processual penal internacional. São Paulo: Atlas, 2013. p. 6; MADRUGA, Antenor. O Brasil e a jurisprudência do STF na Idade Média da cooperação jurídica internacional, cit., dentre outros. Também é a expressão usada no Anteprojeto de lei de cooperação jurídica internacional, convertido em Projeto de Lei n. 4.905/2005.
} 
Com efeito, cooperar significa "atuar, juntamente com outros, para um mesmo fim; contribuir com trabalho, esforços, auxílio; colaborar" ${ }^{\prime 23}$. Pode-se dizer, portanto, que “auxílio", "ajuda" e "assistência" podem ser usados como sinônimos de "cooperação".

Entretanto, como observa LUIZ FABricio ThaUmATURGo VergueIRo, muitas vezes a jurisdição nacional ou estrangeira pode depender do intercâmbio, não somente entre órgãos judiciais, mas também entre órgãos administrativos e policiais de Estados diversos, razão pela qual o termo "judicial" não atende todas as circunstâncias possíveis de auxílio internacional ${ }^{24}$. "Jurídica" seria, portanto, a expressão mais apropriada.

Assim, entendemos que o termo adotado, “cooperação jurídica internacional”, por genérico, seja o que mais abrange as diferentes modalidades de cooperação, quer para a realização de atos processuais, extraprocessuais penais, quer para a investigação policial.

É ativa a cooperação jurídica quando parte do Brasil a iniciativa do pedido de cooperação; passiva, quando o Brasil é o receptor do pedido de cooperação ${ }^{25}$.

Estado requerente é o nome dado ao país emissor do pedido de cooperação. $\mathrm{O}$ país onde será cumprido o ato solicitado é chamado de Estado requerido ${ }^{26}$.

A cooperação jurídica internacional pode ocorrer no plano horizontal estabelecida entre Estados igualmente soberanos - ou no plano vertical ${ }^{27}$ - firmada por

${ }^{23}$ HOUAISS, Antônio; VILLAR, Mauro Salles. Dicionário Houaiss da língua portuguesa. Rio de Janeiro: Objetiva, 2001. p. 829.

${ }^{24}$ VERGUEIRO, Luiz Fabricio Thaumaturgo. Implementação da cooperação jurídica internacional vertical, cit., p. 355.

${ }^{25}$ Nesse sentido, ABADE, Denise Neves. Direitos fundamentais na cooperação jurídica internacional: extradição, assistência jurídica, execução de sentença estrangeira e transferência de presos, cit., p. 41. "Ou seja, se estivermos falando de uma necessidade da jurisdição nacional, de obtenção de atos a serem praticados por agentes públicos estrangeiros, diz-se que a hipótese é de 'cooperação ativa'. No sentido contrário, tem-se a 'cooperação passiva' quando o direito nacional passa a regulamentar a realização de atos públicos nacionais - administrativos ou judiciais - que sejam instrumentos à função jurisdicional estrangeira" (VERGUEIRO, Luiz Fabricio Thaumaturgo. Apontamentos gerais sobre a cooperação jurídica internacional e suas modalidades. In: FERNANDES, Antonio Scarance; ZILLI, Marcos Alexandre Coelho (Coord.). Direito processual penal internacional. São Paulo: Atlas, 2013. p. 379.

${ }^{26}$ Os termos "Estado requerente" e "Estado requerido" são fruto da tradução ao vernáculo português de grande parte dos tratados multilaterais e bilaterais, além de ser o mais usual na doutrina.

${ }^{27}$ Segundo Antonio Cassese (Lineamenti di diritto internazionale penale: diritto processuale. Bologna: Il Mulino, 2006. v. 2, p. 46), a cooperação jurídica internacional pode se dar em dois planos: horizontal (ou interestadual) e vertical (ou supraestatal). A cooperação jurídica internacional em plano horizontal ou interestadual, em que os países postam-se em um mesmo plano, ocorre em geral através da celebração de tratado internacional entre as partes interessadas. Cooperação jurídica vertical é o auxílio judiciário prestado por um Estado soberano a algum Tribunal Internacional de caráter supranacional. No nível vertical ou supranacional, parte-se do pressuposto de que o órgão de justiça internacional (tribunais internacionais) possui atribuição não somente às pessoas sujeitas à sua soberania, mas também à soberania de outro Estado. Assim, as decisões em relação ao cumprimento de medidas em cooperação jurídica internacional têm natureza vinculante ao Estado requerido e, em caso de descumprimento, é possível socorrer-se de mecanismos de atuação coercitiva. No mesmo sentido, ZILLI, Marcos Alexandre Coelho. Cooperação e auxílio com o Tribunal Penal Internacional. Boletim IBCCRIM, São Paulo, v. 162, maio 2006. 
tribunais ou organizações internacionais e supranacionais, de um lado, e Estados, de outro. Destaque-se: o foco da dissertação está voltado à cooperação jurídica horizontal apenas.

As medidas processuais penais suscetíveis a cooperação jurídica internacional podem ser relativas ao direito estrangeiro ou a atos judiciais, que se dividem em atos judiciais não-decisórios (citação, notificação e intimação) e atos judiciais decisórios (medida cautelar patrimonial, busca e apreensão, quebra de sigilo, extradição). Os autos meramente administrativos podem operar direta e informalmente entre autoridades judiciais, policiais ou ministeriais.

Quanto aos procedimentos através dos quais o pedido de cooperação jurídica se instrumentaliza, indica-se a classificação proposta por FÁBIO RAMAZZINI BECHARA ${ }^{28}$ : a) procedimento com o objetivo de entregar pessoas processadas ou condenadas por um Estado a outro (extradição); b) procedimento que se destina à nacionalização de sentença estrangeira, dando-lhe eficácia executiva (homologação de sentença estrangeira); c) procedimento voltado à prática de atos diversos daqueles que constituem objeto da extradição e da homologação de sentença estrangeira, tais como a produção de provas, a execução de meios de obtenção de provas, a comunicação de atos processuais, o cumprimento de medidas cautelares patrimoniais, dentre outros (carta rogatória); d) procedimento do auxílio direto, que se confunde com o procedimento da carta rogatória, com a diferença de que é dotado de maior agilidade e menos burocracia ${ }^{29}$.

A esta última classificação, proposta por BECHARA, acrescentamos outros dois procedimentos: e) procedimento para a remoção de um indivíduo condenado por um Estado, para cumprir pena no território de seu Estado de origem ${ }^{30}$ (transferência de presos); f) procedimento para a transferência de processo-crime de um Estado a outro (transferência de processos), para assegurar a boa administração da justiça ${ }^{31}$.

\footnotetext{
${ }^{28}$ BECHARA, Fábio Ramazzini. Cooperação jurídica internacional em matéria penal: eficácia da prova produzida no exterior, cit., p. 34.

${ }^{29}$ BECHARA, Fábio Ramazzini. Cooperação jurídica internacional em matéria penal: eficácia da prova produzida no exterior, cit., p. 34.

${ }^{30}$ TOFFOLI, José Antonio Dias; CESTARI, Virgínia Charpinei Junger. Mecanismos da cooperação jurídica internacional no Brasil, cit., p. 26.

${ }^{31}$ Prevista no art. 21 da Convenção de Palermo (Decreto 5.015, de 12 de março de 2004) e também na Convenção de Viena Contra o Tráfico Ilícito de Entorpecente (Decreto n. 154, de 26 de junho de 1991). Trata-se de medida importante, quer para centralizar a instrução penal - caso várias jurisdições estejam envolvidas - quer como alternativa nos casos em que a extradição se mostre inviável, por exemplo, quando o acusado tem domicílio no Estado requerido, e este seja o país de sua nacionalidade.
} 
A doutrina distingue, ainda, três níveis de cooperação jurídica internacional quanto ao objeto: no primeiro nível, estão as citações, intimações e notificações, além das medidas de caráter investigativo e instrutório; no segundo, as medidas capazes de gerar gravames patrimoniais; no terceiro e último nível, estão envolvidas as medidas capazes de restringir direitos pessoais, em especial, o direito à liberdade ${ }^{32}$.

Por fim, as bases para a cooperação jurídica internacional são as leis internas e os tratados e convenções internacionais, que podem ser regionais, bilaterais ou multilaterais. Na ausência de tratado, evoca-se o princípio da reciprocidade ${ }^{33}$, também usado quando há ponto omisso no diploma.

\subsection{A cooperação jurídica internacional vista como processo}

No cenário da nova ordem mundial, em consequência da positivação das normas de direitos humanos, pode-se dizer que resta flexibilizada a concepção clássica de soberania, segundo a qual a cooperação jurídica internacional seria questão afeta apenas ao interesse entre dois Estados soberanos ${ }^{34}$ - e, por isso, a pessoa alcançada direta ou indiretamente pela medida deveria observar o desenrolar dos atos como simples espectador ${ }^{35}$.

\footnotetext{
${ }^{32}$ VERGUEIRO, Luiz Fabricio Thaumaturgo. Apontamentos gerais sobre a cooperação jurídica internacional e suas modalidades, cit., p. 379. No mesmo sentido, v. CERVINI, Raul; TAVARES, Juarez. Princípios da cooperação judicial penal internacional no Protocolo do Mercosul, cit.; GRINOVER, Ada Pellegrini. Processo penal transnacional: linhas evolutivas e garantias processuais. Revista Brasileira de Ciências Criminais, São Paulo, v. 3, n. 9, p. 44-45, jan./mar. 1995. Semelhantemente, SÉrgio Moro estabelece critério de coercitividade da cooperação em matéria penal quanto ao objeto: (i) atos de comunicação; (ii) produção de provas; (iii) efetivação de medidas de cunho assecuratório; (iv) efetivação de decretos de confisco criminal; (v) extradição. Estas três últimas têm caráter evidentemente mais coercitivo que as demais (Cooperação jurídica internacional em casos criminais: considerações gerais, cit., p. 18).

${ }^{33} \mathrm{Na}$ ausência de tratado, o Brasil e outros países concedem extradição, ou atendem a outro pedido de cooperação jurídica internacional, mediante declaração de reciprocidade, segundo a qual, ocorrendo crime análogo no país requerido, o país requerente se compromete a conceder a extradição ou a cumprir o pedido de assistência solicitado (ACCIOLY, Hildebrando; NASCIMENTO E SILVA, G. E.; CASELLA, Paulo Borba. Manual de direito internacional público. 18. ed. São Paulo: Saraiva, 2010. p. 519).

34،Já dissemos que existe uma concepção clássica da entre-ajuda judicial penal, originada no âmbito dos jusprivatistas, a qual reivindica a exclusividade dos Estados como sujeitos dessas instâncias, desconhecendo o valor das partes substanciais da cooperação, que são tanto estes mesmos Estados quanto seus cidadãos. Graças ao aporte da moderna doutrina italiana, entre outras, hoje se reconhece o fato de que, por suas características, grande parte dos casos de assistência judicial penal internacional atinge, direta ou indiretamente, a situação daquelas pessoas concretas alcançadas pelas medidas de cooperação, provocando inúmeras vezes danos irreversíveis em sua esfera de liberdade ou em seu patrimônio.” (CERVINI, Raul; TAVARES, Juarez. Princípios da cooperação judicial penal internacional no Protocolo do Mercosul, cit., p. 74).

${ }^{35}$ Observa DENISE NEVES ABADE que a negação da incidência dos direitos fundamentais nos pleitos cooperacionais decorre da teoria, ainda hoje reinante em alguns países, do "non-inquiry integral" ou "teoria da não indagação integral", surgida nos EUA no início do século XX. De acordo com essa teoria, "os tribunais do Estado requerido em uma extradição deveriam abster-se de investigar e se debruçar sobre matérias referentes à proteção de direitos fundamentais do Estado requerente. Bastaria que fossem
} 
RAÚL CERVINI reconhece a existência de três posicionamentos possíveis no que se refere à natureza jurídica da cooperação jurídica internacional: para uma primeira corrente, o juiz do Estado requerido tem jurisdição própria e original em relação aos atos procedimentais da assistência internacional. Assim, as decisões do juiz do Estado requerido incidem sobre o processo principal do Estado requerente por meio das diligências que concede ou denega; para uma segunda corrente, a jurisdição do Estado requerido atuaria por delegação do Estado requerente, a jurisdição principal, de sorte a haver uma mútua dependência entre ambas as jurisdições; uma terceira corrente defende existir uma interação processual-funcional internacional, o que significa dizer que a autoridade do Estado requerido só pode dar trâmite a medidas que não se encontrem proibidas por suas leis internas ${ }^{36}$.

As três correntes reconhecidas por CERVINI pressupõem a existência de real e dinâmica integração do processo que está sob a jurisdição do Estado requerente - o processo "principal”, destinatário da medida solicitada em assistência jurídica - com o procedimento a se desenrolar na jurisdição do Estado requerido, com vistas a consecução do pedido.

Esta interação ocorre na medida em que a eficácia e utilidade do processo que está sob a jurisdição do Estado requerente dependa do ato solicitado em assistência internacional. Por outro lado, o procedimento que se origina sob a jurisdição do Estado requerido (a partir do pedido de assistência) não tem um fim em si mesmo: justifica-se em razão do processo principal estrangeiro.

Segundo ANTENOR MADRUGA, numa perspectiva mais ampla da cooperação jurídica internacional, é possível constatar uma complementaridade entre jurisdições, tendo como essencial a constatação:

“... de que a característica global das sociedades atuais, ainda juridicamente vinculadas a Estados soberanos, produz fatos e ameaças sociais transjurisdicionais suficientes para comprometer a eficácia do poder jurisdicional e a própria justificação do Estado como a organização suprema e independente de pacificação social. O controle desses fatos e ameaças transjurisdicionais pelos próprios Estados,

cumpridas as regras previstas no tratado de extradição ou ainda que houvesse mera promessa de reciprocidade, para que a extradição fosse determinada". Modernamente, entretanto, tal teoria tem sido mitigada ou até mesmo afastada, a permitir a incidência dos direitos da pessoa atingida pela medida de cooperação (Direitos fundamentais na cooperação jurídica internacional: extradição, assistência jurídica, execução de sentença estrangeira e transferência de presos, cit., p. 86-107).

${ }^{36}$ CERVINI, Raul; TAVARES, Juarez. Princípios da cooperação judicial penal internacional no Protocolo do Mercosul, cit., p. 54-57. 
essencial para a efetividade de suas funções soberanas, não existirá no mundo de hoje sem que as jurisdições se complementem por estreita cooperação, ${ }^{, 37}$.

Haveria, por assim dizer, nas palavras de VLADMIR ARAS, uma acessoriedade do procedimento da cooperação em relação ao processo principal estrangeiro, "já que se destinam à produção de provas ou à 'produção' do sujeito passivo da relação processual, mediante sua apresentação a outro Estado seja para prestar declarações, defender-se de uma acusação ou para cumprir uma sentença penal condenatória" ${ }^{38}$.

Logo, o procedimento deflagrado no Estado requerido em decorrência do pedido de assistência jurídica, chamado por DENISE ABADE de "processo cooperacional", anela-se ao processo principal estrangeiro do Estado requerente, assessorando-o em relação a atos relativos à fase processual (citatória ou probatória) ${ }^{39}$, podendo conter também atos de cunho cautelar, como o arresto e o sequestro de bens ${ }^{40}$. Vinculados a jurisdições que se complementam mutuamente por laços de estreita cooperação judiciária, o processo cooperacional acaba sendo o longa manus, ou seja, o desmembramento ou prolongamento do processo principal estrangeiro. Neste sentido, frise-se que o Código de Processo Penal brasileiro, em seu artigo 780, confere à carta rogatória o mesmo status da carta precatória ${ }^{41}$.

Portanto, os instrumentos de cooperação jurídica internacional desenvolvem-se no âmbito interno através de verdadeiros processos, os processos cooperacionais, que estão sujeitos às balizas do due process of law. Pode-se falar, assim, no direito da pessoa atingida ao devido processo legal cooperacional, pois o processo cooperacional está sujeito aos mesmos princípios garantistas que regem, no território dos Estados cooperantes, o devido processo legal, com suporte na Constituição Federal, nos Códigos e demais leis, bem como nos tratados internacionais humanitários.

\footnotetext{
${ }^{37}$ MADRUGA, Antenor. O Brasil e a jurisprudência do STF na Idade Média da cooperação jurídica internacional, cit., p. 92.

${ }^{38}$ ARAS, Vladmir. O papel da autoridade central nos acordos de cooperação penal internacional, cit., p. 62-63.

${ }^{39}$ Frise-se que o tema da presente dissertação é tratar da cooperação jurídica internacional sob o foco das medidas cautelares patrimoniais. Portanto, embora o termo "cooperação jurídica internacional" seja genérico, integrando uma amplitude de atos, não cuidaremos da assistência meramente administrativa nem dos atos de cooperação pré-processual, tampouco estudaremos os instrumentos da extradição, homologação de sentença estrangeira, transferência de presos e de processos.

${ }^{40}$ ABADE, Denise Neves. Direitos fundamentais na cooperação jurídica internacional: extradição, assistência jurídica, execução de sentença estrangeira e transferência de presos, cit., p. 310.

41، Art. 780. Sem prejuízo de convenções ou tratados, aplicar-se-á o disposto neste Título à homologação de sentenças penais estrangeiras e à expedição e ao cumprimento de cartas rogatórias para citações, inquirições e outras diligências necessárias à instrução de processo penal".
} 
Destaca Marcos AleXANDre Coelho Zilli que a garantia do devido processo legal, embora possa assumir algumas variações "em face dos diferentes aspectos culturais encontrados nos sistemas jurídicos", contém um núcleo rígido que "permite revelar a diretriz de uma marcha processual ideal a ser implementada e obedecida". O respeito ao devido processo legal passou a ser previsto nos diplomas internacionais, tornando-se um direito humano internacionalmente afirmado. Trata-se de conjunto de garantias que atendem um standard mínimo do fair trial e prestam papel decisivo para a harmonização dos sistemas jurídicos nacionais ${ }^{42}$.

Por essa razão, a Jurisprudência do Tribunal Constitucional espanhol (TCE) consagra o direito do indivíduo a um processo cooperacional constitucionalmente adequado. Para o TCE, o Estado requerente, em seu pedido, não pode, quer pelos seus atos no passado, quer pela repercussão de seus atos no futuro, afetar a essência da garantia do devido processo legal definida nos tratados internacionais humanitários. Uma vez violado esse núcleo duro do devido processo legal pelo Estado requerente, a cooperação deve ser denegada, não importando o ditame dos tratados cooperacionais nem as leis gerais de cooperação ${ }^{43}$.

\subsection{A concepção trilateral da cooperação jurídica internacional}

Consoante demonstrado, existe efetiva relação processual penal nos pedidos de cooperação jurídica internacional. Trata-se do chamado processo cooperacional, que está sujeito aos limites e garantias do due process of law, da mesma maneira como está qualquer outro processo nacional.

A relação processual se trava, em um primeiro momento, perante o Estado requerente, no processo principal em função do qual se solicita a medida em assistência judiciária. Na sequência, desmembra-se essa mesma relação processual, para dar origem, no ordenamento do Estado requerido, em caráter de acessoriedade, ao procedimento através do qual se cumprirá a medida solicitada.

O processo principal e o processo cooperacional são inter-relacionados pelo objeto (o segundo visa a satisfazer o primeiro) e também pela parte atingida, que lhes

\footnotetext{
${ }^{42}$ ZILLI, Marcos Alexandre Coelho. Os caminhos da internacionalização do processo penal. In: In: FERNANDES, Antonio Scarance; ZILLI, Marcos Alexandre Coelho (Coord.). Direito processual penal internacional. São Paulo: Atlas, 2013, p. 37-39.

${ }^{43}$ ABADE, Denise Neves. Direitos fundamentais na cooperação jurídica internacional: extradição, assistência jurídica, execução de sentença estrangeira e transferência de presos, cit., p. 121-129.
} 
acaba sendo comum. Assim, no relacionamento entre os Estados requerente e requerido, desponta a presença de um terceiro sujeito que interpõe seus direitos e garantias na ajuda recíproca entre os países. Este terceiro sujeito, também chamado de "concernido" ou "pessoa atingida", é a pessoa a quem a questão processual objeto da cooperação concerne diretamente, atingindo seus direitos fundamentais ${ }^{44}$.

RAUL CERVINI ${ }^{45}$, citando a doutrina italiana, defende existir (no que prefere denominar cooperação judicial penal internacional ${ }^{46}$ ) uma "interação processual-funcional entre estruturas jurisdicionais de diferentes países". "Processual", porque há uma interação processual, um "fluido de trânsito jurisdicional entre Estados". A funcionalidade se percebe frente a uma necessária "continuidade jurídica que viabilize um fluido trânsito jurisdicional entre os Estados-partes formais - sem desconhecer os direitos das partes concernidas".

Segundo o autor, o equilíbrio entre a eficiência e os direitos da parte atingida seria a "funcionalidade legitimante da moderna cooperação internacional". Nessa linha de raciocínio, propõe CERVINI uma visão antropocêntrica sobre a cooperação, de forma que "o trato entre os Estados soberanos deve estar também acompanhado pelo imperioso reconhecimento dos direitos do concernido" ${ }^{47}$.

Trilhando essa linha de pensamento, defende ADA PELLEGRINI GRINOVER ${ }^{48}$ ter havido sensível mudança em matéria de cooperação jurídica internacional. Da tradicional visão bidimensional dos tratados de extradição, celebrados em benefício dos Estados envolvidos e sem o reconhecimento da pessoa atingida, passou-se ao esforço de construir a cooperação internacional numa dimensão trilateral.

A dimensão trilateral da cooperação jurídica internacional, no entender da autora, compreende relação processual na qual figuram como partes o Estado solicitante do pedido de cooperação, o Estado destinatário do pedido e, vinculado a ambos, em uma relação triangular, a pessoa destinatária do ato rogado, desta vez, figurando como sujeito de direitos.

\footnotetext{
${ }^{44}$ CERVINI, Raul; TAVARES, Juarez. Princípios da cooperação judicial penal internacional no Protocolo do Mercosul, cit., p. 76.

${ }^{45}$ CERVINI, Raul; TAVARES, Juarez. Princípios da cooperação judicial penal internacional no Protocolo do Mercosul, cit., p 50.

${ }^{46} \mathrm{O}$ autor prefere a expressão “cooperação judicial penal internacional” a "cooperação jurídica internacional em matéria penal", que é adotada no presente trabalho.

${ }^{47}$ CERVINI, Raul; TAVARES, Juarez. Princípios da cooperação judicial penal internacional no Protocolo do Mercosul, cit., p 50.

${ }^{48}$ GRINOVER, Ada Pellegrini. Processo penal transnacional: linhas evolutivas e garantias processuais, cit., p. 40-83.
} 
Difere a visão trilateral da antiga concepção bilateral (Estado-Estado) da cooperação, portanto, justamente o reconhecimento da pessoa atingida como efetivo sujeito de direitos e garantias tutelados pelas normas internacionais de direitos humanos e pelas normas constitucionais e legais de seu próprio país.

A concepção trilateral da cooperação jurídica internacional está assentada, portanto, sobre duas premissas fundamentais, segundo GRINOVER.

A primeira premissa afirma que a cooperação jurídica internacional em matéria penal envolve a existência de verdadeiros processos jurisdicionais, já demonstramos no item anterior.

A segunda premissa afirma que, como seria em qualquer processo jurisdicional e incidentes, a cooperação jurídica internacional só pode desenvolver-se em contraditório. O contraditório é estabelecido entre os sujeitos da relação jurídica cooperacional: o juiz do Estado requerente, o juiz do Estado requerido e a pessoa atingida. Assim, esta relação processual é tríplice e dela devem sempre participar as partes em contraditório.

Crítica que cumpre ser feita à teoria da trilateralidade da cooperação jurídica internacional proposta por GRINOVER, diz respeito ao fato de que ela exclui a participação do Ministério Público, que atua, seja na cooperação ativa - como parte no processo estrangeiro $^{49}$, tem interesse no ato a ser cumprido em auxílio mútuo - seja na cooperação passiva - porque, na maioria das vezes, manifesta-se pelo cumprimento ou não da medida; participa do ato solicitado; e pode até mesmo propor medida perante o judiciário do Estado requerido, em representação do Estado requerente ${ }^{50}$.

Com efeito, se o processo cooperacional, acessório ao processo estrangeiro, desenvolve-se em contraditório, de acordo com os preceitos do devido processo legal, é de se questionar como se travaria o contraditório no processo cooperacional sem que as partes do processo principal - incluindo o Ministério Público, e não apenas o concernido pudessem influir igualmente na realização do ato solicitado ao Estado requerido.

O Ministério Público, apesar de integrar os órgãos constitutivos do Estado, atua no processo principal e no processo cooperacional, em grande parte dos casos, como parte. A atuação do Ministério Público como parte, assim como a atuação do concernido, não se

\footnotetext{
${ }^{49}$ Partimos da premissa de que o Ministério Público figura como parte na ação penal pública.

${ }^{50} \mathrm{~A}$ depender do instrumento de cooperação que o pedido de medida cautelar assume perante o Estado requerido, carta rogatória e auxílio direto (v. capítulo III, relativo às medidas cautelares patrimoniais no contexto da cooperação jurídica internacional).
} 
confunde com a relação entre os Estados requerente e requerido na cooperação jurídica. Estados requerente e requerido são partes da relação de direito internacional que se concretiza no pedido de assistência jurídica, mas, paralelamente, concernido e Ministério Público também atuam como partes do processo cooperacional que se desenvolve no Estado requerido ${ }^{51}$.

De qualquer maneira, os instrumentos de assistência jurídica internacional desenrolam-se no ordenamento interno como verdadeiros processos jurisdicionais. A diferença é que envolvem diferentes países. Assim, não há como se vislumbrar a cooperação jurídica internacional em matéria penal como uma relação linear, que se estabeleceria apenas entre as autoridades dos Estados requerente e requerido. $\mathrm{Na}$ cooperação jurídica internacional em matéria penal, conclui GRINOVER, "a angulação da relação processual é a pedra de toque que transforma um mero procedimento administrativo num verdadeiro processo" ${ }^{152}$.

Destarte, a cooperação jurídica internacional não representa relação cujo interesse esteja circunscrito aos Estados. Trata-se de efetiva relação processual transnacional - porque opera entre sistemas jurídico-processuais de dois Estados -, que pressupõe o reconhecimento dos direitos da pessoa envolvida ${ }^{53}$.

Uma vez incidindo sobre direitos fundamentais do indivíduo, nos processos de cooperação jurídica internacional, assim como em qualquer processo em contraditório, devem ser asseguradas às partes envolvidas as garantias do due process of law, ou, como já dito anteriormente, ao devido processo legal cooperacional.

\footnotetext{
${ }^{51}$ Sobre o papel do Ministério Público na cooperação jurídica internacional, v. LESSA, Luiz Fernando Voss Chagas. Persecução penal e cooperação internacional direta pelo Ministério Público. Rio de Janeiro: Lumen Juris, 2013.

${ }^{52}$ GRINOVER, Ada Pellegrini. Processo penal transnacional: linhas evolutivas e garantias processuais, cit., p. 40-83.

${ }^{53}$ Nesse sentido: “como pano de fundo da Cooperação Jurídica Internacional, está presente a questão a respeito dos direitos humanos e dos direitos fundamentais do indivíduo, ponto axial de todo o ordenamento jurídico brasileiro, especialmente depois da proeminência que lhe foi conferida pela Constituição Federal de 1988. Por isso, não pode faltar à discussão do tema um olhar sobre dois prismas, que dizem respeito à perspectiva a ser adotada no momento de concretizar a cooperação: de um lado, uma perspectiva ex parte principis, ou seja, a lógica do Estado preocupado com a governabilidade e com a manutenção de suas relações internacionais; de outro, a perspectiva ex parte propuli, a dos que estão submetidos ao poder, e cujas preocupações são a liberdade, tendo como conquista os direitos humanos. O estado brasileiro não pode abdicar dessas duas perspectivas ao estabelecer os mecanismos de Cooperação Jurídica Internacional, seja quando celebra acordos internacionais, assumindo obrigações perante outros Estados soberanos, seja quando procura dar assistência a brasileiros que estão no exterior, ou que estão aqui, mas têm necessidades com reflexos internacionais" (ARAÚJO, Nádia de (Coord.). Cooperação jurídica internacional no Superior Tribunal de Justiça: comentários à Resolução nº 9/2005, cit., p. 1-2).
} 
Disto também decorre a obrigatoriedade do Estado demandado a um duplo dever de observância, principalmente das garantias da pessoa atingida: além de assegurar os direitos do concernido no processo que se trava perante seu território em consequência do pedido de cooperação, deve, ainda, observar se a pessoa atingida não teve os direitos violados no processo estrangeiro, segundo o ordenamento do Estado requerente.

Ainda que o ato objeto rogado não infrinja valores constitucionais do Estado requerido, não pode violar a ordem constitucional do Estado requerente ${ }^{54}$. A busca por eficiência na cooperação não pode servir de justificativa para os Estados desrespeitarem sua própria ordem pública.

Logicamente, essa visão da assistência jurídica internacional como a relação processual que envolve Estado requerente, Estado requerido e as partes em contraditório não se aplica a todas as modalidades de cooperação, mas somente à cooperação jurisdicional, ou seja, às autoridades incumbidas de atividade jurisdicional, para quem se dirigem os pedidos de assistência internacional cujo objeto é o cumprimento de medidas cautelares patrimoniais.

Conforme será tratado adiante, a cooperação jurídica internacional nem sempre está voltada à tomada de ato de cunho jurisdicional, nem está limitada à existência de um processo judicial. Existe também a chamada cooperação administrativa, como, por exemplo, a simples notificação de ato já praticado, a solicitação de dados cadastrais não recobertos por sigilo, ou o pedido de esclarecimentos ao Estado requerente acerca da vigência e alcance de determinada norma no país ${ }^{55}$. Tais atos de assistência meramente

\footnotetext{
54 “A incidência direta ou imediata dos direitos fundamentais nos pedidos cooperacionais consiste no reconhecimento de que as normas de direitos fundamentais vinculam todos os atos do Estado em seu território, inclusive aqueles que são realizados a pedido de outro Estado. Logo, os pleitos cooperacionais devem ser realizados pelo Estado requerente de acordo com os direitos fundamentais protegidos em sua Constituição ou nos tratados internacionais de direitos humanos celebrados, sem que seja necessário que tal incidência esteja prevista nos tratados cooperacionais ou nas leis gerais de cooperação. (...). A premissa básica da aplicação imediata é que os diretos fundamentais dos indivíduos sujeitos da cooperação devem ser protegidos pelo Estado requerido, inclusive contra os efeitos dos atos passados ou efeitos dos atos futuros, a serem praticados pelo Estado requerente. Na essência, a teoria da aplicação imediata sustenta que o Estado requerente não pode omitir-se a compactuar com violação passada de direitos fundamentais ou permitir que ocorra violação futura destes direitos pelo Estado requerente. Tal omissão acarretaria em verdadeira violação de direitos por parte do Estado requerido, da mesma maneira que ocorre em relação aos seus próprios atos. Para evitar essa 'lesão ou vulneração indireta de direitos fundamentais', os direitos fundamentais, tais quais delimitados no Estado Requerido, incidem sobre os pleitos cooperacionais" (ABADE, Denise Neves. Direitos fundamentais na cooperação jurídica internacional: extradição, assistência jurídica, execução de sentença estrangeira e transferência de presos, cit., p. 107-108).

${ }^{55}$ VERGUEIRO, Luiz Fabricio Thaumaturgo. Apontamentos gerais sobre a cooperação jurídica internacional e suas modalidades, cit., p. 384-385.
} 
administrativa costumam se realizar independentemente do desenvolvimento do processo cooperacional, não havendo, também, como se falar em "parte" atingida.

\subsubsection{Legitimação ativa, ampla defesa e o contraditório do concernido}

Como vimos, a cooperação jurídica internacional em matéria penal não é questão afeta a Estados circunscritos em suas próprias soberanias e interesses. Trata-se de processo jurisdicional a integrar: Estado requerente, Estado requerido e a pessoa cujos direitos e garantias possam ser afetados pela diligência solicitada, o concernido. Em decorrência dessa trilateralidade da cooperação internacional, ao concernido, como sujeito de direitos e parte do processo cooperacional, assiste o direito de fazer requerimentos à autoridade do Estado requerido, devendo-lhe ser assegurada, ainda, a ampla defesa e o contraditório.

Pode-se dizer, portanto, que o concernido tem legitimação para comparecer e defender plenamente seus interesses e direitos no processo cooperacional. Deve-lhe ser assegurada a ampla possibilidade - efetiva, fática e não puramente formal e teórica - de intervir no processo cooperacional, com vistas a prevenir eventual gravame a seu direito.

Para o exercício desta legitimação, defende RAÚL CERVINI ser necessária a notificação pessoal do concernido acerca do processo cooperacional e, preferencialmente, anteriormente ao cumprimento do ato, ressalvados os atos sigilosos (como acaba ocorrendo em medidas cautelares patrimoniais) em relação aos quais o prévio conhecimento, pelo concernido, pode frustrar a eficácia da medida solicitada ${ }^{56}$.

Ainda para CERVINI, a possibilidade de intervenção do concernido nos atos do processo cooperacional decorre de "mínima coerência teórica", intrinsecamente ligada à possibilidade de a pessoa vir a sofrer prejuízos resultantes da execução das medidas solicitadas, o que é ainda mais evidente nas medidas constritivas pessoais - extradição - e patrimoniais cautelares - assistência jurídica para bloqueio e sequestro de ativos ${ }^{57}$.

Como fontes legais, tratados internacionais de caráter humanitário, tal como o Pacto Internacional de Direitos Civis e Políticos, de 1966, e a Convenção Americana sobre

\footnotetext{
${ }^{56}$ CERVINI, Raul; TAVARES, Juarez. Princípios da cooperação judicial penal internacional no Protocolo do Mercosul, cit., p. 82.

${ }^{57}$ CERVINI, Raul; TAVARES, Juarez. Princípios da cooperação judicial penal internacional no Protocolo do Mercosul, cit., p. 75.
} 
Direitos Humanos, de 1969, preveem, respectivamente, nos artigos 14, 3, e 8', 2, "b", que o acusado tem o direito de ser informado, prévia e minuciosamente, a respeito da acusação. Tais tratados reconhecem, portanto, direitos e garantias fundamentais que devem ser respeitados pelos países signatários. Ademais, grande parte das constituições dos Estados democráticos reconhece a garantia da ampla defesa e do contraditório (inclusive a Constituição Federal brasileira de 1988, em seu artigo $5^{\circ}$, inciso LV).

A praxe dos países, contudo, é diversa. Em geral, medidas são solicitadas em assistência internacional, tramitam e depois são devolvidas ao Estado requerente já com o gravame irreparável deflagrado, sem que haja notícia da participação da pessoa atingida.

A possibilidade de o concernido participar direta e ativamente do processo cooperacional, sendo mais comum na extradição, dificilmente se cumpre nos demais instrumentos de cooperação internacional, perpetuando a tradicional ideia da cooperação como questão entre Estados, que despreza os direitos e garantias da pessoa atingida.

Esta visão, que sacrifica as garantias da pessoa atingida em prol de pretendida eficácia da assistência ${ }^{58}$, está impressa nos tratados bilaterais de assistência em matéria penal firmados pelo Brasil. Referidos tratados, em grande parte, vedam expressamente a intervenção e até mesmo o acesso do concernido ao processo cooperacional ${ }^{59}$.

No Brasil, questiona-se a validade do cumprimento de diligências solicitadas em assistência internacional sem a oitiva inicial do interessado. O Supremo Tribunal Federal, em alguns precedentes, reconheceu a necessidade de proteção do contraditório e da ampla defesa nos processos cooperacionais. Porém, nas medidas

\footnotetext{
${ }^{58}$ CERVINI, Raul; TAVARES, Juarez. Princípios da cooperação judicial penal internacional no Protocolo do Mercosul, cit., p. 77.

${ }^{59}$ De maneira geral, a quase totalidade dos tratados subscritos ou aderidos pelo Brasil preveem a possibilidade de o Estado requerente exigir do Estado requerido sigilo sobre o pedido e seu conteúdo, salvo na medida do que seja necessário para executar o pedido (por exemplo, v. disposição do artigo 19 da Convenção das Nações Unidas contra o Crime Organizado Transnacional - Decreto n. 5.015, de 12 de março de 2004). Por outro lado, existe completo "esquecimento" dos direitos e garantias do concernido nos tratados internacionais, no que se refere à assistência judicial. Estabelece-se, contudo, que, a despeito do caráter confidencial, o Estado requerente não obstará para que o Estado requerido revele, em processos de sua jurisdição, informações que sejam fator de absolvição de uma pessoa acusada (artigo 46, inciso $5^{\circ}$, da Convenção das Nações Unidas contra a Corrupção - Decreto n. 5.687, de 31 de janeiro de 2006). Os tratados também preveem presteza e agilidade no cumprimento das solicitações estrangeiras, via Autoridades Centrais. Por seu caráter garantista singular, a reconhecer os direitos fundamentais do concernido, merece destaque o tratado bilateral Brasil-Peru (Decreto n. 3.988, de 29 de outubro de 2001) no que se refere a medidas cautelares: estabelece o artigo 13 , inciso $6^{\circ}$, que "qualquer requerimento deverá ser executado unicamente de acordo com a legislação interna da parte requerida e, em particular, com observância e garantia dos direitos de qualquer pessoa que possa ser atingida pela execução da medida". No mais, a forma de cumprimento das medidas em assistência judiciária dependerá das normas previstas no ordenamento jurídico do Estado requerido.
} 
cautelares, para que se evite sua frustração, permitiu que o contraditório se dê de maneira postergada ${ }^{60}$. Esta é a orientação, aliás, disposta no artigo $8^{\circ}$, da Resolução 9 , do Superior Tribunal de Justiça ${ }^{61} 62$.

\subsection{Cooperação jurídica e o Direito Processual Penal Internacional}

A aldeia global, à medida que estabeleceu esforços no sentido de aumentar o rigor na repressão à criminalidade transnacional ${ }^{63}$, também precisou fixar metas de aproximação entre os sistemas processuais penais ${ }^{64}$ para assegurar a consecução da

\footnotetext{
${ }^{60}$ A título de exemplo, citamos o seguinte julgado: “A resolução n. 9, de 04 de maio de 2005, do Superior Tribunal de Justiça, editada para regulamentar o trâmite das cartas rogatórias e homologações de sentença estrangeira, que passaram à sua competência em razão do EC n. 45/2004, estabelece, no art. $8^{\circ}$, que a parte interessada será intimada para, no prazo de 15 (quinze) dias, impugnar a carta rogatória. No parágrafo único, todavia, abre-se exceção: a medida solicitada por carta rogatória poderá realizar-se sem prévia audiência da parte interessada, quando sua intimação poder resultar na ineficácia do ato ou atos de cooperação internacional. É exatamente o caso dos autos. A carta rogatória n. 1.621 destina-se a proceder à busca de bens em proveito da infração penal. Trata-se de cautelar que necessitava ser efetivada sem a ciência nem a presença do paciente, as quais poderiam frustrar a diligência. Isto não significa, todavia, que, tão logo realizada e documentada nos autos a diligência, não se deva assegurar ao interessado a possibilidade de defesa, mediante contraditório diferido, retardado ou postergado, a fim de reverenciar a regra contida no art. $5^{\circ}$, inciso LIV, da Constituição da República." (Supremo Tribunal Federal, HC 90485, rel. Min. Cesar Peluso, j. Em 10-4-2007, Segunda Turma, DJ de -8.07.2007).

61 “Art. $8^{\circ}$ A parte interessada será citada para, no prazo de 15 (quinze) dias, contestar o pedido de homologação de sentença estrangeira ou intimada para impugnar a carta rogatória. Parágrafo único. A medida solicitada por carta rogatória poderá ser realizada sem ouvir a parte interessada quando sua intimação prévia puder resultar na ineficácia da cooperação internacional."

${ }^{62}$ Trataremos especificadamente sobre a incidência do contraditório e da ampla defesa nos processos cooperacionais no capitulo IV.

${ }^{63}$ Segundo CARLOS EDUARDO ADRIANO JAPIASSÚ, o chamado direito penal internacional "é fruto da convergência entre a necessidade de aplicação internacional das regras penais internas e a existência de aspectos penais nas normas internacionais". Seria, assim, o ramo do direito que define os crimes internacionais próprios e impróprios e que estabelece as regras relativas à aplicação extraterritorial do Direito Penal interno, à imunidade de pessoas internacionalmente protegidas e à cooperação internacional em todos os seus níveis." (O Tribunal Penal Internacional. Rio de Janeiro: Lumen Juris, 2004. p. 15-16). No mesmo sentido, ARAÚJO JÚNIOR, João Marcelo de. Introdução à teoria geral do direito penal Internacional. In: KUEHNE, Maurício (Org.). Ciência penal: coletânea de estudos: homenagem à Alcides Munhos Netto. Curitiba: JM, 1999. Vários autores fazem a diferenciação entre "direito penal internacional" e "direito internacional penal" (v. ZAFFARONI, Eugenio Raúl; PIRANGELI, José Henrique. Manual de direito penal brasileiro - parte geral. 2. ed. São Paulo: Ed. Revista dos Tribunais, 1999. p. 151-157; DOTTI, René Ariel. Curso de direito penal: parte geral. 2. ed. Rio de Janeiro: Forense, 2005. p. 195-203). Para uma visão do "direito internacional penal" como parte do direito internacional, v. CASSESE, Antonio. International criminal law. 2.ed. Oxford: Oxford University Press, 2007. p. 16-17. Sobre a visão de um "direito penal internacional", v. JESCHECK, Hans-Henrich. O objeto do direito penal internacional e sua mais recente evolução. Revista de Direito Penal, n. 6, p. 7-20, abr./jun. 1972.

${ }^{64}$ Segundo MARCOS AlEXANDRE COELHO ZILli: "A intensificação das relações internacionais, o maior intercâmbio de informações propiciado pelos novos aparatos tecnológicos, a transposição de fronteiras pela criminalidade comum, a criação de espaços comunitários supranacionais e a afirmação de bens jurídicos internacionais, cada qual a seu modo e intensidade, vêm contribuindo para um crescente movimento de internacionalização do processo penal. Não se trata, é certo, de fenômeno exclusivo desse ramo do direito. Tampouco assume ele uma única forma. Em realidade, as manifestações são variadas até mesmo porque são informadas por necessidades específicas. O fato é que o processo penal transpôs as barreiras impostas pela soberania estatal, não sendo mais instrumento construído, exclusivamente, para a aplicação do direito penal doméstico" (Os caminhos da internacionalização do processo penal, cit., p. 28).
} 
cooperação judiciária internacional. Assim, multiplicaram-se tratados multilaterais e bilaterais com previsão expressa de assistência jurídica recíproca em matéria penal ${ }^{65}$.

Nesse contexto, a doutrina costuma falar no advento de um direito processual penal internacional, no qual a cooperação jurídica internacional estaria inserida. O Direito Processual Penal Internacional integra "toda regra de processo penal que não se situe exclusivamente na esfera interna de um Estado e, de algum modo, adquira projeção externa"66. Abrangeria questões referentes ao processo penal das cortes e tribunais penais internacionais e, ainda, aquelas relativas à colaboração entre tais tribunais e as autoridades dos diversos países, nas atividades de investigação criminal e de instrução processual penal ${ }^{67}$.

Representaria o Direito Processual Penal Internacional, nos dizeres de Antonio ScArance Fernandes, “o estudo do Direito Processual em face de sua projeção externa, além dos limites estreitos de um único Estado, configurando, em suma, um novo método de enfoque do direito processual" ${ }^{\prime 68}$.

Marcos AleXANDRe COELHO ZiLli ${ }^{69}$ identifica quatro movimentos rumo à internacionalização do processo penal, quais sejam: a) a construção de um paradigma internacional do justo e do devido processo penal; b) a elaboração de normas informadas pelo desejo de obtenção de maior eficiência na persecução de crimes internacionais; c) a elaboração de normas processuais penais uniformes para os espaços comunitários; d) a construção de uma Justiça Penal Internacional ${ }^{70}$.

\footnotetext{
${ }^{65}$ Assim, afirma GAETANO DE AMICIS: “(...) na sociedade globalizada, a esfera de relevância do ilícito penal assume sempre maior complexidade e tende a transcender as fronteiras dos Estados, intensificando, de um lado, os processos de cooperação, harmonização e unificação penal e pondo em crise, de outro lado, os fundamentos justificativos de um jus puniendi tradicionalmente circunscrito ao território nacional". Por isso, "não é possível, hoje, encarar realisticamente o problema da jurisdição penal sem levar cm conta os vínculos de interdependência entre os sistemas dos diversos Estados e sem uma colaboração rápida e eficaz entre as autoridades judiciárias nacionais" - tradução livre. (Cooperazione giudiziaria e corruzione internazionale: verso un sistema integrato di forme e strumenti di collaborazione tra le autorità giudiziaria. Milano: Giuffrè, 2007. p. 1).

${ }^{66}$ FERNANDES, Antonio Scarance. O direito processual penal internacional. In: FERNANDES, Antonio Scarance; ZILLI, Marcos Alexandre Coelho (Coords.). Direito processual penal internacional. São Paulo: Atlas, 2013. p. 6.

${ }^{67}$ VERGUEIRO, Luiz Fabricio Thaumaturgo. Implementação da cooperação jurídica internacional vertical, cit., p. 18.

${ }^{68}$ FERNANDES, Antonio Scarance. O direito processual penal internacional, cit., p. 4.

${ }^{69}$ ZILLI, Marcos Alexandre Coelho. Os caminhos da internacionalização do processo penal, cit., p. 28-66.

${ }^{70}$ Semelhantemente, a internacionalização do processo penal se justifica pela ideia de uma justiça penal universal, segundo RENATA ROSSINI FASANO. A justiça universal - que a autora denomina justiça internacional penal - tem hoje, como mecanismo de atuação, o exercício da competência repressiva universal (A competência repressiva universal no direito internacional penal, cit., p. 18).
} 
Especificamente no âmbito da União Europeia, a internacionalização do Direito Processual Penal se deu, segundo BERnd SCHUNEMANN ${ }^{71}$, com fundamento em duas premissas: o princípio do reconhecimento mútuo e a abolição da dupla incriminação. Com a sensível diminuição da desconfiança entre os países integrantes da União Europeia e o estabelecimento de uma política criminal homogênea - a estabelecer, por exemplo, entre os Estados-membros da União Europeia, um rol de delitos a serem incriminados necessariamente no âmbito interno -, foi criado o cenário propício à livre circulação de decisões judiciais, aprimorando a internacionalização do processo penal no âmbito regional europeu.

Defendemos que o Direito Processual Penal Internacional integra o processo firmado na relação entre diferentes sistemas processuais penais de Estados que, no âmbito da mútua cooperação, estabelecem tratados e acordos multilaterais e bilaterais, visando ao desenvolvimento e à integração econômica, política e jurídica ${ }^{72}$.

Os pontos de contato entre os sistemas processuais envolvidos na cooperação jurídica internacional - tanto no plano vertical, entre Tribunais internacionais e os Estados anuentes, quanto no plano horizontal, entre países igualmente soberanos - se estabelecem por normas processuais penais internacionais de garantia, resultado da internacionalização dos direitos humanos, que configuram um padrão ético universal e aproximam os sistemas processuais penais dos países ${ }^{73}$.

Assim, partiremos da premissa de que todo o ato processual penal, mesmo envolvendo os ordenamentos de dois Estados diversos, é afeto ao interesse desse Direito Processual Penal Internacional. Na cooperação jurídica internacional, a relação trilateral - e processual - que se estabelece entre o Estado requerente, o Estado requerido, executor da medida rogada, e a pessoa investigada, acusada ou condenada não pode ser deixada de fora; deve, sim, ser tratada no contexto do Direito Processual Penal Internacional.

\footnotetext{
${ }^{71}$ SCHUNEMANN, Bernd. As bases do processo penal transnacional. Revista Brasileira de Ciências Criminais, São Paulo, v. 19, n. 90, p. 195, maio/jun. 2011.

${ }^{72}$ Nesse sentido, ANTONIO SCARANCE FERNANDES faz a separação do direito processual penal em cinco campos de estudo, dentre os quais estão "as regras processuais penais que disciplinam as formas de cooperação entre os países" (O direito processual penal internacional, cit., p. 6).

${ }^{73} \mathrm{~V}$. BECHARA, Fábio Ramazzini. Cooperação jurídica internacional em matéria penal: eficácia da prova produzida no exterior, cit.
} 


\subsection{Eficiência e garantismo no processo cooperacional}

Dois movimentos diametralmente opostos impulsionam o desenvolvimento da cooperação jurídica internacional, influenciando o processo cooperacional.

Em um primeiro movimento, existe a consciência da cooperação jurídica internacional, não apenas como questão entre Estados, mas como efetiva relação processual da qual emergem garantias fundamentais do concernido ${ }^{74}$. A consciência dos direitos individuais do concernido é, a propósito, manifestada nos diversos compromissos internacionais assumidos em matéria de direitos humanos.

Em um segundo movimento, encontram-se tratados internacionais de criminalização, de onde emerge a necessidade de intensificação da cooperação jurídica internacional na luta contra a criminalidade organizada transnacional. Os Estados, agindo como players globais, têm somado esforços, compelindo-se mutuamente no intuito de desenvolver mecanismos modernos de cooperação, mais céleres e eficientes ${ }^{75}$.

Esses movimentos operam no campo normativo e doutrinário internacional por meio de "vetores" ${ }^{76}$, correntes que impulsionam o processo cooperacional a maior eficiência, mas também ao reconhecimento das garantias fundamentais do concernido ${ }^{77}$.

\footnotetext{
${ }^{74}$ O termo "concernido" é usado por RAÚl CERVINI e JUAREZ TAVARES na obra Princípios da cooperação judicial penal internacional no Protocolo do Mercosul, cit., p. 155.

${ }^{75}$ Segundo ADA PELLEGRINI GRINOVER: "dois valores relevantes, de certo modo antagônicos, ou pelo menos dialeticamente opostos, têm emergido recentemente em sede de cooperação jurídica internacional em matéria penal: de um lado, a necessidade de intensificar a referida cooperação na luta contra o crime; de outro, a consciência cada vez mais profunda de que os direitos fundamentais devem colocar-se como termo de referência nessa matéria e, consequentemente, como limite à cooperação internacional em matéria penal" (O processo em evolução. 2. ed. Rio de Janeiro: Forense Universitária, 1998. p. 156).

${ }^{76}$ Também reconhecem a existência de vetores que influenciam a cooperação jurídica internacional em matéria penal: ABADE, Denise Neves. Direitos fundamentais na cooperação jurídica internacional: extradição, assistência jurídica, execução de sentença estrangeira e transferência de presos, cit., p. 58; SOUZA, Solange Mendes de. Cooperação jurídica penal no Mercosul: novas possibilidades. Rio de Janeiro: Renovar, 2001. p. 140. Os vetores analisados não eliminam a existência de fatores outros igualmente relevantes a uma maior eficiência na cooperação jurídica internacional, bem como à proteção dos direitos fundamentais da pessoa atingida. Para o propósito do presente trabalho, entretanto, abordaremos os vetores que, da nossa parte, mostram-se mais preponderantes.

${ }^{77}$ Para MiREILle DELMAS-MARTY, o antagonismo dos vetores que influenciam o processo cooperacional à eficiência e ao garantismo decorre propriamente do processo de globalização. Propiciando o quase imediato intercâmbio de mercadorias, capitais e informações culturais, abre-se terreno fértil à disseminação da chamada criminalidade transnacional. Paralelamente, os direitos do homem, consagrados na Declaração de 1948, continuam a reivindicar o reconhecimento de valores universais. Assim, conclui pela existência de um descompasso na confluência desses vetores, pois a globalização consegue ser mais ágil e eficiente que a harmonização dos sistemas jurídicos nacionais, por influência dos direitos humanos. A suposta simetria entre o efeito globalizante da economia e os direitos do homem seria apenas aparente (DELMAS-MARTY, Mireille. O direito penal como ética da mundialização. Revista Portuguesa de Ciência Criminal, Coimbra, ano 14, n. 3, p. 287, jul./set. 2004).
} 


\subsubsection{Eficiência e garantismo}

Eficiência, segundo ANTONIO SCARANCE FERNANDES, é a capacidade, a força de se produzir determinado efeito. A aferição do grau de eficiência diz respeito a maior ou menor capacidade do meio utilizado para se obter o resultado pretendido ${ }^{78}$.

A palavra eficiência costuma ser empregada como sinônimo de efetividade ou de eficácia, embora sejam expressões de significados diversos. Enquanto eficiência é a aptidão para um determinado resultado ${ }^{79}$, eficácia é a qualidade do resultado produzido, levando-se em conta o tipo do resultado, e, por fim, efetividade é o sucesso dos resultados em relação aos objetivos esperados ${ }^{80}$.

ANTONio ScARANCE Fernandes distingue "eficiência do processo penal" da "eficiência no processo penal" ${ }^{81}$.

No que se refere à eficiência do processo, defende o autor que o processo é formado por uma relação jurídica e por um procedimento. Desse modo, a eficiência há de estar presente tanto na relação jurídica, ou seja, na atuação dos sujeitos processuais (Juiz, Ministério Público ou querelante, acusado e seu defensor), quanto no procedimento e nos atos que o compõem ${ }^{82}$.

Já a eficiência no processo penal é analisada no âmbito dos atos que compõem o procedimento e os meios de investigação ou de produção de prova. Eficiente será o processo cujos atos, meio de prova ou meio de investigação forem capazes de produzir o

\footnotetext{
${ }^{78}$ FERNANDES, Antonio Scarance. Reflexões sobre as noções de eficiência e de garantismo no processo penal. In: FERNANDES, Antonio Scarance; ALMEIDA, José Raul Gavião de; MORAIS, Maurício Zanoide de (Coords.). Sigilo no processo penal: eficiência e garantismo. São Paulo: Ed. Revista dos Tribunais, 2008. p. 18.

${ }^{79}$ BECHARA, Fábio Ramazzini. Cooperação jurídica internacional em matéria penal: eficácia da prova produzida no exterior, cit., p. 19.

${ }^{80}$ FERNANDES, Antonio Scarance. Reflexões sobre as noções de eficiência e de garantismo no processo penal, cit., p. 18.

${ }^{81}$ FERNANDES, Antonio Scarance. Reflexões sobre as noções de eficiência e de garantismo no processo penal, cit., p. 21. Sobre a mesma temática, v. FERNANDES, Antonio Scarance. Teoria geral do procedimento e o procedimento no processo penal. São Paulo: Ed. Revista dos Tribunais, 2005.

${ }^{82}$ FERNANDES, Antonio Scarance. Reflexões sobre as noções de eficiência e de garantismo no processo penal, cit., p. 24. De outro vértice, adverte o autor: a análise da eficiência do processo ainda depende do estudo relativo à finalidade do processo penal, havendo três correntes nesse sentido. Para uma primeira corrente, o processo penal objetiva assegurar a defesa do acusado, portanto será eficiente quando assegurar ao acusado todos os meios de exercício de sua defesa; para uma segunda corrente, a finalidade do processo penal é permitir aos órgãos da persecução a apuração dos fatos e a punição dos autores de condutas delituosas. Assim, será eficiente o processo que permitir maior âmbito de atuação aos órgãos de persecução na apuração dos delitos e na condenação de seus autores; para uma terceira corrente, se a finalidade do processo penal é obter um resultado justo que se legitime pelo procedimento adequado, será eficiente o processo que assegurar a ambas as partes o exercício de seus direitos e que as proteger com as garantias constitucionais.
} 
efeito que deles são esperados. Assim, por exemplo, a citação será eficiente quando for capaz de atingir o resultado dela esperado, qual seja, o de dar conhecimento ao acusado dos fatos que lhe foram imputados ${ }^{83}$.

Vimos que a cooperação jurídica internacional se desenvolve através de um processo. Logo, também é possível auferir a eficiência do e no processo cooperacional.

A eficiência do processo cooperacional incide na capacidade dos tratados e convenções internacionais e das medidas de cooperação jurídica internacional por eles instituídas de atingir o resultado esperado. Já a eficiência no processo cooperacional é aquela relativa aos atos propriamente ditos praticados pelos Estados no cumprimento de medidas de assistência mútua (cooperação stricto sensu).

No que se refere ao garantismo, o estudo mais notável certamente se encontra na obra "Direito e Razão: Teoria do Garantismo Penal", de LUIGI FERRAJIOLI ${ }^{84}$.

FERRAJIOLI trabalha com três conceitos de garantismo: a) como modelo normativo de direito, de estreita legalidade, relacionado ao Direito Penal. Trata-se de um modelo que, politicamente, caracteriza-se por tutelar o sujeito com vistas a minimizar a violência e otimizar a liberdade e, juridicamente, impõe limites ao poder punitivo estatal em prol da proteção das garantias dos direitos dos cidadãos; b) como teoria jurídica da validez e efetividade, a operar como legitimador interno do Direito Penal; e c) como filosofia política, pois pressupõe a separação entre direito e moral, validade e justiça, ser e dever $\operatorname{ser}^{85}$.

O estudo do garantismo penal interessa ao escopo do presente trabalho, na medida em que o processo histórico dos direitos fundamentais eclodiu na positivação dos direitos humanos, que são a primeira manifestação dos direitos fundamentais, segundo LUIGI FERRAJIOLI ${ }^{86}$. O processo de positivação dos direitos humanos é associado ao efeito

\footnotetext{
${ }^{83}$ FERNANDES, Antonio Scarance. Reflexões sobre as noções de eficiência e de garantismo no processo penal, cit., p. 25.

${ }^{84}$ FERRAJOLI, Luigi. Direito e razão: teoria do garantismo penal. Tradução Ana Paula Zomer Sica et al. São Paulo: Ed. Revista dos Tribunais, 2010.

${ }^{85}$ BECHARA, Fábio Ramazzini. Cooperação jurídica internacional em matéria penal: eficácia da prova produzida no exterior, cit., p. 19-20.

${ }^{86}$ ROSA, Alexandre Morais da. Garantismo jurídico e controle de constitucionalidade material. Rio de Janeiro: Lumen Juris, 2005. p. 21.
} 
da globalização e da mitigação (crise) das soberanias nacionais ${ }^{87}$, na busca de uma maior integração mundial $^{88}$.

O caráter cogente desses tratados de natureza humanitária opera como vetor de garantismo na cooperação jurídica internacional e impõe aos países um standard mínimo de proteção aos direitos fundamentais do concernido. Portanto, a visão internacional dos direitos humanos acresceu-se à cooperação jurídica internacional, tendo sido importante a desnaturar a visão clássica da cooperação como questão afeta unicamente a Estados e a inserir, em papel de destaque, a pessoa atingida, como sujeito de direitos e garantias, erigindo-a como sujeito de direito internacional ${ }^{89}$.

Assumiremos a posição de que eficiência e garantismo não são expressões antagônicas no processo penal. O processo não será menos eficiente se forem assegurados os direitos fundamentais do acusado. Também não será justo o processo se o atendimento cego às garantias fundamentais da pessoa impedir a obtenção do fim esperado, extirpandolhe a eficiência. Eficiência e garantismo são expressões que se somam, se complementam ${ }^{90}$.

Justo processo é aquele no qual os órgãos de persecução conseguem, em um prazo mínimo razoável, atingir o objetivo de apurar o delito e de responsabilizar seus autores, também assegurando, ao investigado, acusado ou sentenciado o exercício pleno e efetivo de seus direitos e garantias processuais ${ }^{91}$.

\footnotetext{
${ }^{87}$ Acerca da teoria de uma soberania mitigada, v. PIOVESAN, Flavia; GOMES, Flávio (Coords.). O sistema interamericano de proteção dos direitos humanos e o direito brasileiro. São Paulo: 2000. p. 159.

${ }^{88}$ ROSA, Alexandre Morais da. Garantismo jurídico e controle de constitucionalidade material, cit., p. 24.

${ }^{89}$ Conforme ensina SYlvia HelenA DE FIGUEIREDo STEINER, "o histórico da evolução dos instrumentos internacionais de direitos humanos demonstra a grande 'revolução' que se operou no direito internacional, a partir do momento em que se passa a reconhecer a pessoa humana como sujeito de direito internacional" ( $A$ Convenção Americana sobre Direitos Humanos e sua integração ao processo penal brasileiro, cit., p. 57).

${ }^{90}$ Segundo o magistério de ANTONIO SCARANCE FERNANDES, há uma recente tendência no processo penal à busca de equilíbrio entre a exigência de se assegurar as garantias fundamentais do indivíduo no processo e o clamor que tem ganhado corpo por maior efetividade do sistema persecutório e da segurança pública, a fim de se atingir um equilíbrio entre os direitos à liberdade e à segurança, ambos tutelados pelo artigo $5^{\circ}$ da Constituição Federal. Esse equilíbrio a ser almejado repele a ideia de que existiria um antagonismo entre eficiência e garantismo. Deve o Estado estabelecer maneiras que o faça utilizar as normas de direito repressivo, necessárias para a concretização do direito fundamental à segurança, e assegurar ao acusado todos os mecanismos essenciais para a defesa de sua liberdade (O equilíbrio entre eficiência e o garantismo e o crime organizado. Revista Brasileira de Ciências Criminais, São Paulo, ano 16, n. 70, p. 226-268, jan./fev. 2008).

${ }^{91}$ KALB, Luigi. La "ricostruzione orale" del fato tra "efficienza” ed "efficacia" del processo penale. Torino: G. Giappichelli, 2005. p. 202.
} 


\subsubsection{Vetores de eficiência no processo cooperacional}

Podem ser identificados como vetores de eficiência no processo cooperacional: a normativa processual penal internacional de caráter incriminatório e de tutela; a obrigatoriedade de os Estados cooperarem mutuamente na luta contra a criminalidade transnacional; os esforços à evolução do paradigma da cooperação interessada ao paradigma da confiança mútua, hoje presente no âmbito da União Europeia.

Trata-se de vetores que funcionam, ora como mandados de incriminação, ora como mandados de otimização do fluxo cooperacional entre os países.

\subsubsection{A obrigatoriedade em cooperar}

O Direito Internacional surgiu com o fim precípuo de regular as relações entre os Estados, o que se dá mediante tratados internacionais.

Os tratados são manifestações de vontades bilaterais ou multilaterais a que os Estados aderem no exercício de sua soberania ${ }^{92}$. A obrigatoriedade dos tratados pode ser inferida tanto do preceito do pacta sunt servanda - de que "os acordos devem ser cumpridos" - quanto do direito costumeiro internacional, partindo-se do pressuposto de que os Estados só firmam tratados com o objetivo de cumpri-los ${ }^{93}$.

Mas, se os Estados são igualmente soberanos, há de se questionar se o Direito Internacional careceria de força executiva caso o Estado descumprisse tratado internacional do qual fosse signatário, indo, portanto, de encontro à própria manifestação de vontade externada e formalizada ${ }^{94}$.

No plano interno, o descumprimento contratual pelo particular poderia gerar sérias sanções de ordem civil. Ocorre que, no plano internacional, a ausência de um órgão

\footnotetext{
${ }^{92}$ TROTTA, Sandro Brescovit; FERREIRA, Luciano Vaz. Da obrigatoriedade de cooperar e os recursos cabíveis em casos de descumprimento de tratado internacional. In: BALTAZAR JÚNIOR, Paulo José; LIMA, Luciano Flores de (Orgs.). Cooperação jurídica internacional em matéria penal. Porto Alegre: Verbo Jurídico, 2010, p. 96.

${ }^{93}$ TROTTA, Sandro Brescovit; FERREIRA, Luciano Vaz. Da obrigatoriedade de cooperar e os recursos cabíveis em casos de descumprimento de tratado internacional, cit., p. 96.

${ }^{94}$ TROTTA, Sandro Brescovit; FERREIRA, Luciano Vaz. Da obrigatoriedade de cooperar e os recursos cabíveis em casos de descumprimento de tratado internacional, cit., p. 97.
} 
externo supranacional - a vincular todas as nações ${ }^{95}$ - gera dúvida se haveria maneiras de impor sanções ao Estado que descumprisse algum tratado internacional ${ }^{96}$.

A questão perde, em parte, sua força, se consideramos a atuação das Nações Unidas sobre os direitos humanos. ANNE-MARIE SLAUGHTER ${ }^{97}$ defende que o surgimento das Nações Unidas foi importante para o Direito Internacional, na medida em que possibilitou a mudança do conceito de soberania-controle para uma soberania responsabilidade. Os Estados passaram a ser livres para assinar ou não a Convenção das Nações Unidas, mas, se o fizerem, terão de aceitar as responsabilidades de sua assinatura.

Assim, internamente, os Estados são responsáveis por respeitar os direitos básicos de seus cidadãos e, externamente, por respeitar a soberania dos demais Estados. O Estado assume a responsabilidade de proteger seus cidadãos, mas, quando falha em sua obrigação, a comunidade internacional atua através das Nações Unidas ${ }^{98}$.

Esse poder das Nações Unidas de intervir nas controvérsias surgidas no plano internacional é fator preponderante para que os Estados se sintam na obrigação de cooperar. Assim, por mais paradoxal que pareça, o grau de independência de um país dependerá necessariamente de sua relação cooperativa com os demais Estados.

Adicionalmente, os próprios tratados internacionais, em sua grande parte, imprimem mecanismos próprios de solução de eventuais controvérsias ou do mero não atendimento a um preceito firmado ${ }^{99}$. Obviamente, esses mecanismos não esgotam os

\footnotetext{
${ }^{95}$ A União Europeia é exemplo de supranacionalidade, mas sua atuação é limitada a alguns países europeus signatários do Tratado da União Europeia.

${ }^{96}$ TROTTA, Sandro Brescovit; FERREIRA, Luciano Vaz. Da obrigatoriedade de cooperar e os recursos cabíveis em casos de descumprimento de tratado internacional, cit., p. 98.

${ }^{97}$ SLAUGHTER, Anne-Marie. Sovereighty and power in a networked world order, cit., p. 288-292.

${ }^{98}$ SLAUGHTER, Anne-Marie. Sovereighty and power in a networked world order, cit., p. 288-292, p. $288-292$.

${ }^{99}$ Os tratados e convenções multilaterais estabelecem de maneira geral que eventuais controvérsias sobre a interpretação ou aplicação do correspondente diploma internacional deverão ser resolvidas pela via da negociação. Na impossibilidade de resolvê-la pela negociação dentro de um prazo razoável, a pedido de uma das partes, a causa será submetida a arbitragem (a Convenção contra o Tráfico Ilícito de Entorpecentes e Substâncias Psicotrópicas - Decreto n. 154, de 26 de junho de 1991 ainda prevê, em seu artigo 32, inciso $2^{\mathrm{o},}$ que a controvérsia não resolvida pela mediação nem por juízo arbitral será submetida por petição de qualquer um dos Estados-partes à decisão pela Corte Internacional de Justiça. No mesmo sentido, artigo 66, inciso $2^{\circ}$, da Convenção Das Nações Unidas contra a Corrupção - Decreto n. 5.687, de 31 de janeiro de 2006). No plano regional, semelhante disposição está prevista no Protocolo de Assistência Jurídica Mútua em Assuntos Penais (Mercosul) - Decreto n. 3.468, de 17 de maio de 2000: eventual controvérsia deverá ser resolvida mediante negociações diplomáticas diretas e, na impossibilidade de obtenção de acordo pelos Estados-partes, são aplicados os procedimentos previstos no Sistema de Solução de Controvérsias do Mercosul, com a atuação de um órgão arbitral específico. Por fim, nem todos os tratados bilaterais celebrados pelo Brasil fixam regras de solução de controvérsias. A exemplo dos tratados bilaterais BrasilChina e Brasil-Portugal, eventual controvérsia, se não puder ser solucionada diretamente entre Autoridades Centrais, será submetida à negociação pela via diplomática.
} 
recursos ainda cabíveis pela via diplomática, política e até mesmo pela via dos órgãos jurisdicionais colegiados previamente constituídos, como é o caso da Corte Internacional de Justiça e, no campo regional, da Corte Interamericana de Direitos Humanos ${ }^{100}$.

A disponibilidade de mecanismos na seara internacional para instituir e impor um verdadeiro dever de cooperação ${ }^{101}$ aos países contribui sensivelmente com a eficiência do processo cooperacional.

\subsubsection{A evolução do paradigma do soberanismo ao da mútua confiança}

A cooperação jurídica internacional desenvolveu-se através da influência de paradigmas informadores, ou seja, de "valores essenciais que moldaram a elaboração dos tratados internacionais de cooperação e ainda o costume internacional (reciprocidade) que regem a matéria”. Esses paradigmas orientam a interpretação dos diplomas internacionais que envolvem cooperação ${ }^{102}$.

Fundamentalmente, três paradigmas podem ser apontados como informadores da cooperação jurídica internacional em matéria penal: a) paradigma do soberanismo; b) paradigma da cooperação interessada; c) paradigma da confiança mútua.

\footnotetext{
${ }^{100}$ Nesse sentido, enfatizando a necessidade dos Estados de cooperar, a Resolução da Assembleia Geral da ONU, n. 2.526, de 1970, dispõe: "States have de duty do co-operate with one other, irrespective of the differences in their political, economic and social systems, in the various spheres of international relations, in order to maintain international peace and security and to promote international economic stability and progress, the general welfare of nations and international co-operation free from discrimination based on such differences" (Fonte: www.un.org. Acessado em: 21.09.2013). A importância e necessidade de maior cooperação mútua entre os países também está impressa nos preâmbulos dos tratados e convenções multilaterais e bilaterais firmados pelo Brasil, não podendo passar incólume, ainda, o compromisso com a cooperação jurídica internacional fixado pela Constituição Federal brasileira de 1988, em seu art. $1^{\circ}$, inciso IX.

101 “O respeito à obrigação de promover a Cooperação Jurídica Internacional é imposto pela própria comunidade internacional. Qualquer resistência ou desconfiança com relação ao cumprimento de atos provenientes do estrangeiro deve ceder lugar ao princípio da boa-fé que rege as relações internacionais de países soberanos, tanto nos casos cíveis quanto penais. Afinal, o mundo está cada dia menor e mais próximo". (ARAÚJO, Nádia de (Coord.). Cooperação jurídica internacional no Superior Tribunal de Justiça: comentários à Resolução no 9/2005, cit., p. 3). Neste mesmo sentido, observa VLADIMIR ARAS: "Enfim, se antes da cooperação jurídica internacional (inclusive a cooperação penal) baseavase na teoria da cortesia internacional (comitas gentium), tendo passado pela utilização corriqueira do princípio da reciprocidade para estabelecer a colaboração dos Estados, o certo é que hoje a assistência tem por base tratados internacionais. Mais: em ordenamentos jurídicos como o nosso surge um verdadeiro dever constitucional de cooperação, ligado à ideia de acesso à justiça como direito humano e ao dever de persecução e evitação da impunidade, como corolários de um direito fundamental à segurança pública. É justamente em razão desse dever de cooperação que cresce a importância das autoridades centrais, principalmente nos países em que a prática da entreajuda penal internacional ainda é incipiente." (O papel da autoridade central nos acordos de cooperação penal internacional, cit., p. 70).

${ }^{102}$ ABADE, Denise Neves. Direitos fundamentais na cooperação jurídica internacional: extradição, assistência jurídica, execução de sentença estrangeira e transferência de presos, cit., p. 58.
} 
O paradigma do soberanismo orientou os primeiros diplomas normativos de direito internacional sobre cooperação, além de ter consolidado o costume internacional da reciprocidade, até hoje operante. Este paradigma é baseado na desconfiança e na pretensão de hegemonia do seu sistema jurídico sobre o do outro Estado solicitante ou solicitado na cooperação jurídica internacional. Eram comuns os choques entre os sistemas criminais nacionais dos Estados, baseados em princípios distintos, ocasionando a desigualdade da cooperação, uma vez condicionada à obediência ao conjunto de valores de um dos Estados $^{103}$. Nesse quadro, as cooperações ocorriam esporadicamente.

Com a carta das Nações Unidas, proibiu-se o uso da força. Além disso, o fenômeno da transnacionalização do crime organizado impulsionou o crescimento da cooperação jurídica internacional ${ }^{104}$. Foi instituído, então, o paradigma da cooperação interessada, por meio da celebração dos tratados, pelo qual se prevê que a cooperação sempre ocorra, embora hajam casos em que a cooperação é - e pode ser - negada. Neste paradigma, os Estados passam a negociar tratados multi e bilaterais, a estruturar órgãos internos de apreciação dos pleitos cooperacionais (autoridades centrais) e a positivar as hipóteses de eventual denegação do pedido de cooperação em nome de valores nacionais ${ }^{105}$.

A cooperação interessada acabou recebendo reforços na busca de proteção aos direitos humanos e também na concepção de um ius $\operatorname{cogens}^{106}$. A cooperação jurídica internacional passou a ser estruturada pela necessidade de dialogar com os princípios fundamentais. Por isso, a aceitação dos pleitos cooperacionais não se limita mais ao papel das chancelarias. O Brasil, assim como todos demais os países da América Latina, encontra-se nesse segundo paradigma, da cooperação interessada ${ }^{107}$. Trata-se, também, do

\footnotetext{
${ }^{103}$ ABADE, Denise Neves. Direitos fundamentais na cooperação jurídica internacional: extradição, assistência jurídica, execução de sentença estrangeira e transferência de presos, cit., p. 59.

${ }^{104}$ ABADE, Denise Neves. Direitos fundamentais na cooperação jurídica internacional: extradição, assistência jurídica, execução de sentença estrangeira e transferência de presos, cit., p. 62.

${ }^{105}$ ABADE, Denise Neves. Direitos fundamentais na cooperação jurídica internacional: extradição, assistência jurídica, execução de sentença estrangeira e transferência de presos, cit., p. 63.

${ }^{106} \mathrm{O}$ princípio do ius cogens foi reconhecido pela primeira vez na Convenção de Viena sobre o Direito dos Tratados de 1969, na qual são expressas obrigações que os Estados são compelidos a atender, independentemente do consentimento ou vontade destes.

107“De resto, a cooperação entre os países do Mercosul não demonstra ter sido influenciada pelo apelo de confiança e solidariedade que deveria existir em um bloco regional que almeja a liberdade de circulação dos fatores de produção. A interpretação dos tribunais brasileiros também não permite aferir que a cooperação mercosulina é regida pelo paradigma da solidariedade e confiança. Pelo contrário, não há nenhuma decisão do Supremo Tribunal Federal (...) ou do Superior Tribunal de Justiça (...) que tenham (sic) valorado a pertença ou não ao Mercosul como fator de convencimento pro cooperatione." (ABADE, Denise Neves. Direitos fundamentais na cooperação jurídica internacional: extradição, assistência jurídica, execução de sentença estrangeira e transferência de presos, cit., p. 68).
} 
modelo adotado pelos países signatários do Mercosul, entre os quais não existe figura de supranacionalidade $^{108}$.

Por uma eficiência ainda maior na cooperação jurídica internacional, tem se fortalecido um terceiro paradigma, o paradigma da confiança, na lógica do incremento da cooperação com base no reconhecimento mútuo das competências dos Estados. Nesse novo paradigma, os países reconhecem a existência de diferenças entre seus ordenamentos, porém superáveis diante dos mesmos princípios, objetivos e interesses.

O paradigma da confiança é a fase em que se encontra a União Europeia, o que incrementa e muito a eficiência da cooperação jurídica internacional entre os países integrante daquela comunidade ${ }^{109} 110$.

Exemplo de eficiência na cooperação jurídica internacional, no âmbito da União Europeia, é o chamado mandado de arresto europeu, um modelo novo de cooperação que veio substituir a extradição no contexto europeu ${ }^{111}$. O objetivo primário desse novo instrumento de cooperação foi substituir a extradição por um procedimento de simples entrega entre autoridades judiciais de distintos Estados, similar ao previsto no Estatuto de Roma ao Tribunal Penal Internacional ${ }^{112}$.

Assevera BEATRIZ Garcia SÁnCHEZ que, em termos terminológicos, o Mandado Europeu de Detenção pouco se distingue da extradição. Ambos se mostram instrumentos de cooperação jurídica internacional atuantes entre os Estados membros, com o objetivo de

\footnotetext{
${ }^{108}$ Apontam Raul Cervini e JuAREZ TAVARes que o "Mercosul se caracteriza pela ausência de supranacionalidade, ou seja, a falta de efeitos diretos de seus textos". Segundo o autor, na União Europeia, "o princípio da primazia significa que as normas comunitárias têm preferência sobre o direito interno". Portanto, "quando o Mercosul optou pela solução intergovernamental, e não supranacional, inviabilizou $a b$ initio a possibilidade de aplicação deste princípio no âmbito do Mercosul" (Princípios da cooperação judicial penal internacional no Protocolo do Mercosul, cit., p. 104-105).

${ }^{109} \mathrm{~A}$ respeito do paradigma da confiança no espaço comunitário europeu e a cooperação jurídica na União Europeia, v. SATZGER, Helmut; ZIMMERMANN, Frank. Dos modelos tradicionais de cooperação judicial ao princípio do reconhecimento mútuo: novos desdobramentos do verdadeiro paradigma da Cooperação Europeia em matéria penal. In: BALTAZAR JÚNIOR, Paulo José; LIMA, Luciano Flores de (Orgs.). Cooperação jurídica internacional em matéria penal. Porto Alegre: Verbo Jurídico, 2010.

${ }^{110}$ LUIGI KALB disserta que agregou, em muito, à eficiência, a adesão dos países europeus ao contexto comunitário, o que se opera através da manifestação de cooperação judiciária fundada no princípio do mútuo reconhecimento das decisões jurisdicionais. Diz o autor: "sem sobra de dúvida, os organismos comunitários são mais ativos em propor iniciativas vistas a favorecer a eficiência da justiça" ( $L a$ "ricostruzione orale" del fato tra "efficienza" ed "efficacia" del processo penale, cit., p. 185).

${ }^{111} \mathrm{O}$ mandado de arresto europeu foi instituído pela Decisão-marco em 13 de junho de 2002, revelando-se mais ágil, rápido e eficaz. Segundo o artigo 1.1 da Decisão-marco, "a ordem de detenção europeia é uma resolução ditada por um Estado membro com vistas à detenção e à entrega, por outro Estado membro, de uma pessoa procurada para responder a uma ação penal, bem como para a execução de uma pena ou para uma medida de segurança privativa de liberdade".

${ }^{112}$ GARCÍA SÁNCHEZ, Beatriz. La extradición en el ordenamiento interno español, internacional y comunitario. Granada: Comares, 2005. p. 69.
} 
entregar determinada pessoa a outro Estado, para ser julgada ou para cumprir condenação no Estado emissor da ordem de detenção. A diferença está, portanto, na aplicação desses institutos de direito comunitário e internacional ${ }^{113}$.

No mandado de arresto europeu, a superação da extradição e sua substituição por simples entrega fundamenta-se na confiança plena e mútua na estrutura e no funcionamento dos respectivos sistemas judiciais penais em respeito às garantias de um processo justo. Isso se dá pois se parte do pressuposto de que "os Estados membros são Estados Democráticos de direito e todos respeitam as obrigações da Convenção Europeia de Direitos Humanos" $" 114$.

Dessa maneira, em virtude do paradigma da confiança nas decisões judiciais no âmbito europeu, o mandado de arresto europeu tramita diretamente entre autoridades judiciárias dos países membros da União Europeia, sem a intervenção de autoridades centrais. Há, ainda, a superação do requisito da dupla incriminação em um extenso rol de crimes.

Outro exemplo, também da realidade europeia, é dado pela decisão do Conselho Europeu de 22 de julho de 2003 que instituiu regras para assegurar o cumprimento de mandados de congelamento de bens e de provas expedidos por um Estado membro e dirigidos à apreensão de objetos, instrumentos e outros elementos de prova relacionados com crimes, no âmbito das persecuções penais ${ }^{115}$.

Como observa Denise Nunes AbAde, a incidência dos direitos fundamentais nos pleitos cooperacionais é fortemente influenciada por esses paradigmas. No paradigma da cooperação interessada, os Estados tendem a incluir a análise da proteção de direitos fundamentais pelo Estado requerente - logicamente, de acordo com a concepção interna, do Estado requerido, de direitos fundamentais. Já sob o prisma da confiança mútua, o Estado requerido adotará uma visão de confiança sobre a preservação dos direitos fundamentais no Estado requerente ${ }^{116}$.

Contudo, mesmo na União Europeia, em que a busca por maior eficiência na cooperação jurídica internacional possibilitou estabelecer as bases do paradigma da mútua

\footnotetext{
${ }^{113}$ GARCÍA SÁNCHEZ, Beatriz. La extradición en el ordenamiento interno español, internacional y comunitario, cit., p. 69.

${ }^{114}$ GARCÍA SÁNCHEZ, Beatriz. La extradición en el ordenamiento interno español, internacional y comunitario, cit., p. 69.

${ }^{115}$ ZILLI, Marcos Alexandre Coelho. Os caminhos da internacionalização do processo penal, cit., p. 49.

${ }^{116}$ ABADE, Denise Neves. Direitos fundamentais na cooperação jurídica internacional: extradição, assistência jurídica, execução de sentença estrangeira e transferência de presos, cit., p. 69.
} 
confiança, remanesce a preocupação em se manter um olhar antropocêntrico sobre a cooperação jurídica internacional nos contextos comunitário ${ }^{117}$ e internacional. Por detrás da integração supranacional, pode-se esconder perigosa flexibilização das regras materiais e processuais de garantia da pessoa atingida.

Como ressalta SILVA SANCHES: “o direito penal da globalização e da integração supranacional será um direito desde logo crescentemente unificado, mas também menos garantista, na qual se flexibilizarão as regras da imputação e no qual se relativizarão as garantias político-criminais substantivas e processuais" 118 .

\subsubsection{Vetores de garantismo no processo cooperacional}

Como vetores de garantismo no processo cooperacional, podemos citar: as normas processuais penais de garantia previstas em Tratados e Convenções internacionais e o ius cogens em relação às normas internacionais humanitárias.

\subsubsection{As normas processuais penais de garantia previstas em Tratados e Convenções internacionais}

No esforço de positivar os direitos humanos e reconhecer o seu caráter universal $^{119}$, vários tratados internacionais foram celebrados nos últimos anos. Esses tratados de direito humanitário são importantes, porque sistematizaram e positivaram, no plano internacional, standards mínimos de garantias.

No plano universal, destacam-se entre os instrumentos de direitos humanos a Declaração Universal dos Direitos do Homem, de 1948; o Pacto de Direitos Civis e Políticos e o Pacto de Direitos Econômicos, sociais e culturais, ambos aprovados no ano de 1966. No plano regional, podemos citar a Convenção Europeia de Direitos Humanos, firmada em 1950, a Carta Africana de Direitos do Homem e dos Povos, de 1986; no âmbito do continente americano, a Declaração Americana dos Direitos e Deveres do

\footnotetext{
${ }^{117}$ Ensina RAÚl CERVINI: "sem prejuízo dos interesses e formulações próprias do relacionamento entre Estados soberanos, toda instância de integração se refere medularmente aos homens, devendo-se priorizar suas necessidades e garantias concretas" (Princípios da cooperação judicial penal internacional no Protocolo do Mercosul, cit., p. 162).

${ }^{118}$ SILVA SANCHÉZ, Jesus-Maria. El derecho penal ante la globalización y la integración supranacional. Revista Brasileira de Ciencias Criminais, São Paulo, v. 6, n. 24, p. 66, out./dez. 1998.

${ }^{119}$ V. BECHARA, Fábio Ramazzini. Cooperação jurídica internacional em matéria penal: eficácia da prova produzida no exterior, cit.
} 
Homem, firmada em 1948 e a Convenção Americana sobre Direitos Humanos (Pacto de San José da Costa Rica), de $1969^{120}$.

Inúmeros direitos - standards mínimos de garantias no processo penal - podem ser extraídos desses tratados humanitários, como, a título de exemplo, direito de ser presumido inocente até que sua culpabilidade tenha sido provada; direito de não ser obrigado a depor contra si mesmo, nem a confessar-se culpado etc.

As regras de direitos humanos dispostas nesses tratados permitem, como observa ANTÔNIO SCARANCE FERNANDES, o exame comparativo entre os direitos e garantias processuais previstos nas constituições dos Estados e aqueles constantes dos textos internacionais e influenciam os ordenamentos internos na reafirmação desses preceitos ${ }^{121}$.

A integração dessas normas humanitárias de direito internacional nos ordenamentos internos esbarra na controvérsia doutrinária entre as chamadas escolas monista e dualista. Fugiria ao escopo da dissertação eventual aprofundamento das questões atinentes a cada uma dessas escolas.

Em termos gerais, os adeptos da escola dualista defendem a coexistência dos ordenamentos internacional e nacional, uma vez que regulamentariam relações distintas: o primeiro regulamenta as relações entre os Estados, e o segundo se dedica a regular a relação entre indivíduos de um determinado Estado. Já que não se regem pelas mesmas relações, não se poderia falar em receptação do Direito Internacional pelo Estado, se o conteúdo da regra interna não correspondesse integralmente ao conteúdo da regra internacional. Neste sentido, nenhum tratado pode ser executado diretamente na ordem interna e, portanto, não confere direitos aos particulares sem antes ser "transformado" em lei interna ${ }^{122}$.

D'outro lado, na visão da escola monista, existiria uma unidade no ordenamento jurídico como um todo, por isso a dicotomia entre os ordenamentos internos e o ordenamento internacional revelaria verdadeiro contrassenso. Para esta corrente, o Estado firma tratados no exercício de sua soberania, que só existe se reconhecida pelo Direito Internacional. As regras estabelecidas nos tratados vinculariam não somente os

\footnotetext{
${ }^{120}$ V. STEINER, Sylvia Helena de Figueiredo. A Convenção Americana sobre Direitos Humanos e sua integração ao processo penal brasileiro, cit.

${ }^{121}$ FERNANDES, Antonio Scarance. O direito processual penal internacional, cit., p. 7.

${ }^{122}$ STEINER, Sylvia Helena de Figueiredo. A Convenção Americana sobre Direitos Humanos e sua integração ao processo penal brasileiro, cit., p. 62.
} 
Estados signatários, mas também os súditos destes. Assim, a celebração de um tratado faz ingressar automaticamente no seu sistema normativo as regras às quais se obrigou, sendo desnecessária a edição de norma interna para que os Tribunais passem a aplicar o tratado na decisão de conflitos $^{123}$.

Sylvia Helena de Figueiredo Steiner adverte que, na doutrina mais moderna, entretanto, "acima da natureza das obrigações decorrentes de tratados e das normas consuetudinárias, há o dever geral para os Estados para que sejam elaboradas leis nacionais em conformidade com as obrigações internacionais assumidas. Esse fato está a demonstrar o reconhecimento de que, nos dias atuais, nenhum Estado pode realizar seus objetivos isoladamente" ${ }^{\prime 124}$.

Assim, a discussão entre as escolas monista e dualista perdeu sensivelmente sua importância. Para se auferir a eficácia e a validade dos tratados nos ordenamentos internos, mais essencial é analisar a posição hierárquica que os tratados ocupam nas legislações internas, o que é crucial para definir-se, por exemplo, qual das normas prevalece em caso de conflito ${ }^{125}$.

O grau de influência das normas internacionais de direitos humanos dependerá, portanto, do status que receberão ao serem incorporadas ao direito interno, se: a) norma supranacional; b) norma constitucional; c) norma supralegal; ou d) norma ordinária ${ }^{126}$.

No que se refere à cooperação jurídica internacional, contudo, como bem observado por DENISE NEVES ABADE, o modo e intensidade da incidência dos direitos fundamentais é um "tema esquecido". Inexistindo norma que estabeleça inequivocamente standards mínimos de garantias voltados ao processo cooperacional, cria-se um conflito.

\footnotetext{
${ }^{123}$ STEINER, Sylvia Helena de Figueiredo. A Convenção Americana sobre Direitos Humanos e sua integração ao processo penal brasileiro, cit., p. 63.

${ }^{124}$ STEINER, Sylvia Helena de Figueiredo. A Convenção Americana sobre Direitos Humanos e sua integração ao processo penal brasileiro, cit., p. 67.

${ }^{125}$ STEINER, Sylvia Helena de Figueiredo. A Convenção Americana sobre Direitos Humanos e sua integração ao processo penal brasileiro, cit., p. 65. Importante mencionar que nenhum Estado pode eximirse da obrigação de respeitar norma de direito internacional invocando as disposições de sua própria constituição. Trata-se do princípio pacta sunt servanda, estabelecido na Convenção de Viena em seu artigo 26. Se é verdade que uma lei interna revoga outra anterior no que lhe for contrária, torna-se difícil manter o mesmo raciocínio quando a "lei anterior" representa norma oriunda de tratado internacional incorporado ao ordenamento interno, na medida em que o Estado tem o dever de respeitar suas obrigações contratuais e não as pode revogar unilateralmente. Não se pode revogar as normas convencionais incorporadas no seio interno - através das regras de revogação aplicadas às normas internas -, a não ser pela renúncia do tratado firmado na seara internacional.

${ }^{126}$ FERNANDES, Antonio Scarance. O direito processual penal internacional, cit., p. 8-9. A esse respeito, v. GEMAQUE, Silvio Cezar Arouk. A necessária influência do processo penal internacional no processo penal brasileiro. 2010. Tese (Doutorado) - Faculdade de Direito da Universidade de São Paulo, São Paulo, 2010.
} 
Segundo ABADE, como há diferença nas normas de direito penal e processual penal entre os Estados envolvidos em cooperação, abre-se espaço à seguinte discussão: o pleito cooperacional violaria os direitos fundamentais como são entendidos no Estado requerido ${ }^{127}$.

É possível identificar três respostas possíveis a esse conflito, de acordo com o posicionamento dos países em relação aos pedidos de assistência jurídica internacional: a) pela teoria do non-inquiry integral, fortemente apoiada pelos EUA, nega-se simplesmente que os direitos fundamentais possam ter alguma influência na cooperação, restrita às relações diplomáticas entre os Estados. A inclusão do tema dos direitos fundamentais nos tratados violaria a separação dos poderes; b) pela a teoria do non-inquiry mitigado, não se nega a possibilidade de invocação dos direitos fundamentais nos processos cooperacionais, porém exige-se que a forma e a intensidade desta incidência se deem nos termos dos tratados ou, no máximo, da lei interna geral da cooperação. A incidência ocorre, portanto, de forma indireta ou mediata; c) pela aplicação dos direitos fundamentais em sua concepção interna (de acordo com o Estado requerido), independentemente de haver previsão no tratado, exige-se que o Estado requerente de adapte, sob pena de indeferimento do pedido. Nesse caso, a incidência dos direitos fundamentais é direta ou imediata ${ }^{128}$.

A opção de resposta adotada pelo Estado brasileiro é a do non-inquiry mitigado, impondo aos pleitos cooperacionais prévio juízo de delibação ${ }^{129}$.

Importante mencionar que o Estado brasileiro tem, na dignidade da pessoa humana, um de seus principais fundamentos (inciso III, artigo $1^{\circ}$, da Constituição Federal de $1988^{130}$ ) e rege-se, em suas relações internacionais, dentre outros princípios, pela prevalência dos direitos humanos (inciso II, do art. $4^{\circ}$, da Constituição Federal ${ }^{131}$ ).

\footnotetext{
${ }^{127}$ ABADE, Denise Neves. Direitos fundamentais na cooperação jurídica internacional: extradição, assistência jurídica, execução de sentença estrangeira e transferência de presos, cit., p. 85.

${ }^{128}$ ABADE, Denise Neves. Direitos fundamentais na cooperação jurídica internacional: extradição, assistência jurídica, execução de sentença estrangeira e transferência de presos, cit., p. 85-86.

${ }^{129}$ De fato, o juízo de delibação é de cognição restrita. Para obstar a cooperação, a defesa da pessoa atingida só pode alegar matéria prevista na Lei n. 6.815/80 (na extradição) ou em tratados. Os direitos fundamentais incidem de maneira indireta, quando previstos nos tratados celebrados pelo Brasil ou quando contidos nas leis brasileiras. Cf. ABADE, Denise Neves. Direitos fundamentais na cooperação jurídica internacional: extradição, assistência jurídica, execução de sentença estrangeira e transferência de presos, cit., p. 97. Os limites da cooperação jurídica internacional impostos pelo Brasil serão tratados no capítulo III.

130“Art. $1^{\circ}$ A República Federativa do Brasil, formada pela união indissolúvel dos Estados e Municípios e do Distrito Federal, constitui-se em Estado Democrático de Direito e tem como fundamentos: (...) III - a dignidade da pessoa humana".

131 “Art. $4^{\mathbf{0}}$ A República Federativa do Brasil rege-se nas suas relações internacionais pelos seguintes princípios:

I - independência nacional;

II - prevalência dos direitos humanos".
} 
Prevaleceu no Supremo Tribunal Federal o entendimento de que, como regra geral, o tratado regularmente inserido no ordenamento interno brasileiro assume o status de lei federal. Já normas internacionais de direitos humanos no ordenamento brasileiro assumiriam, segundo a orientação do Supremo, natureza supralegal e infraconstitucional embora a doutrina defendesse pertencerem à categoria de normas materialmente constitucionais $^{132}$.

Após o advento da Emenda Constitucional n 45, de 2004, a matéria passou a ser disciplinada pelo parágrafo $3^{\circ}$, do artigo $5^{\circ}$, da $\mathrm{CF}$ : “os tratados e convenções internacionais sobre direitos humanos que forem aprovados, em cada Casa do Congresso Nacional, em dois turnos, por três quintos dos votos dos respectivos membros, serão equivalentes às emendas constitucionais" ${ }^{133}$. Deste modo, tratados e convenções internacionais sobre direitos humanos, se aprovados pelo quórum especial previsto no $\S 3^{\circ}$, do artigo $5^{\circ}$, da $\mathrm{CF}$, serão recepcionados pelo ordenamento jurídico brasileiro como normas de hierarquia constitucional ${ }^{134}$ - e com tal status devem incidir diretamente sobre o processo cooperacional tramitado no ordenamento jurídico interno.

\subsubsection{Ius cogens e a internacionalização dos direitos humanos}

O princípio do ius cogens foi reconhecido pela primeira vez na Convenção de Viena sobre o Direito dos Tratados de 1969. Estabelece a Convenção que: "norma imperativa (ius cogens) de direito internacional geral é uma norma aceita e reconhecida pela comunidade internacional dos estados no seu conjunto, como uma norma da qual nenhuma derrogação é permitida e que só pode ser modificada por uma norma de direito internacional geral da mesma natureza" (art. 53) ${ }^{135}$.

\footnotetext{
${ }^{132}$ STEINER, Sylvia Helena de Figueiredo. A Convenção Americana sobre Direitos Humanos e sua integração ao processo penal brasileiro, cit., p. 90-91.

${ }^{133}$ FERNANDES, Antonio Scarance. O direito processual penal internacional, cit., p. 8-9. A esse respeito, v. GEMAQUE, Silvio Cezar Arouk. A necessária influência do processo penal internacional no processo penal brasileiro, cit.

${ }^{134}$ “" Art. $5^{\circ}(\ldots)$.

$\S 3^{\circ}$ Os tratados e convenções internacionais sobre direitos humanos que forem aprovados, em cada Casa do Congresso Nacional, em dois turnos, por três quintos dos votos dos respectivos membros, serão equivalentes às emendas constitucionais".

${ }^{135} \mathrm{Em}$ sua integralidade, dispõe o artigo 53, da Convenção de Viena sobre o Direitos dos Tratados (Decreto $\mathrm{n}^{\circ}$ 7.030, de 14 de dezembro de 2009): "É nulo um tratado que, no momento de sua conclusão, conflite com uma norma imperativa de Direito Internacional geral. Para os fins da presente Convenção, uma norma imperativa de Direito Internacional geral é uma norma aceita e reconhecida pela comunidade internacional dos Estados como um todo, como norma da qual nenhuma derrogação é permitida e que só pode ser modificada por norma ulterior de Direito Internacional geral da mesma natureza."
} 
O ius cogens irradia efeitos no plano internacional, exprimindo obrigações que os Estados são compelidos a atender, independentemente de consentimento ou vontade ${ }^{136}$. A norma de ius cogens tem, por assim dizer, natureza imperativa de direito internacional. Qualquer outra norma instituída por tratado que conflite com a norma de ius cogens tornase nula, extinguindo-se. ${ }^{137}$

\section{Hildebrando Accioly, G. E. Nascimento e Silva e Paulo Borba Gasella} ensinam que não existe teoria dos atos sem teoria da validade. Atribui-se a expressão "tratado" tanto ao documento redigido internacionalmente, quanto ao objeto do documento, que é a norma de direito internacional criada pelo documento. Nesse cenário, “a aparição da noção de norma de jus cogens veio mostrar, como parece evidente, que mesmo a vontade dos estados tem de encontrar limites, e que os estados não poderiam atribuir quaisquer efeitos a determinado tratado" ${ }^{, 138}$.

O reconhecimento do ius cogens, associado ao desenvolvimento da chamada soft law, que exprime deveres morais de natureza internacional ${ }^{139}$ - dentre os quais se insere os direitos humanos -, erigiu qualquer infração aos direitos do homem e da pessoa humana ao patamar de grave violação aos princípios fundamentais do direito universal ${ }^{140}$. Embora inexista consenso neste sentido, a maioria dos valores universais protegidos pela tipificação dos crimes internacionais é interpretada, pela doutrina majoritária, como pertencente à categoria de ius $\operatorname{cogens}^{141}$.

\footnotetext{
${ }^{136}$ ACCIOLY, Hildebrando; NASCIMENTO E SILVA, G. E.; CASELLA, Paulo Borba. Manual de direito internacional público, cit., p. 328. Como exemplo de norma de ius cogens, os autores mencionam os tratados que estabelecem vedação à renúncia pelos Estados-partes, como, por exemplo, a Convenção de Combate à Escravidão (1928), a Convenção sobre Genocídio (1948) e a Convenção sobre a Eliminação de todos os tipos de Discriminação Racial (1965). Mesmo que um Estado renuncie a um desses tratados, continuariam vinculados a determinadas cláusulas.

${ }^{137}$ Assim dispõe o artigo 64, da Convenção de Viena sobre o Direito dos Tratados: "Se sobrevier uma nova norma imperativa de Direito Internacional geral, qualquer tratado existente que estiver em conflito com essa norma torna-se nulo e extingue-se."

${ }^{138}$ ACCIOLY, Hildebrando; NASCIMENTO E SILVA, G. E.; CASELLA, Paulo Borba. Manual de direito internacional público, cit., p. 324.

${ }^{139}$ Segundo SLAUGHTER, por meio das chamadas soft laws, foi instaurado um novo padrão internacional que os Estados tomam emprestado e aplicam no âmbito doméstico (Sovereighty and power in a networked world order, cit., p. 291).

${ }^{140}$ ACCIOLY, Hildebrando; NASCIMENTO E SILVA, G. E.; CASELLA, Paulo Borba. Manual de direito internacional público, cit., p. 339.

${ }^{141}$ FASANO, Renata Rossini. A competência repressiva universal no direito internacional penal, cit., p. 50. Nesse sentido, leciona Sylvia Helena de FigueIREdo Steiner: "Não bastasse a clareza do texto constitucional, não se pode olvidar a natureza imperativa das normas de proteção à pessoa, normas essas que, ao lado de princípios como o pacta sunt servanda, integram o chamado jus cogens, normas obrigatórias que não admitem derrogação, produzindo efeitos erga omnes. Não se pode admitir o poder ilimitado do legislador constituinte. Não se compadece, o mais formalista dos constitucionalistas, com a ideia de que poderia o constituinte originário, a exemplo, consagrar um novo texto constitucional à
} 
A partir do reconhecimento de que existem princípios fundamentais de direito internacional em matéria humanitária, duas consequências importantes podem ser constadas. A primeira consequência está na modificação da estrutura relacional dos Estados, que passou da mera coexistência ao atual cenário do Estado Constitucional Cooperativo ${ }^{142}$. A segunda consequência está na consciência de uma comunidade global, integrada por sujeitos de direito internacional tutelados por uma ordem pública internacional ${ }^{143}$.

FÁBIO RAMAZZINI BECHARA ${ }^{144}$ defende a existência de padrões normativos (standards), entendidos como o complexo de normas de força cogente e de forte conteúdo ético que estabelecem a forma de concretização dos sistemas de direitos, liberdades e garantias. Essas normas interagem no plano nacional e internacional, por meio da unificação e harmonização. Segundo o autor, as normas de direitos humanos qualificam-se como standards normativos universais e são incorporadas pelos sistemas jurídicos dos Estados pelo processo de harmonização, representando um modelo ideal de valores que devem ser atendidos e preservados, independentemente da realidade jurídica de cada Estado ${ }^{145}$.

MiREILle Delmas-MARTY ${ }^{146}$ também entende ser intrínseca ao Direito Penal uma dimensão ética que poderia contribuir na obtenção de um equilíbrio entre a globalização econômica e a universalidade dos direitos do homem. A flexibilização do domínio territorial dos Estados e a consciência cada vez mais latente de que a soberania deve ser compartilhada abriram portas à mundialização do Direito Penal ${ }^{147}$.

\footnotetext{
legalização da escravidão, a autorização para a prática de atos de genocídio, a institucionalização da tortura como meio válido de obtenção de provas de um crime, ou critérios discriminatórios para o exercício de direitos como o de ocupar cargos públicos ou eletivos." (A Convenção Americana sobre Direitos Humanos e sua integração ao processo penal brasileiro, cit., p. 67).

${ }^{142}$ A respeito da formação do Estado Constitucional Cooperativo, v. HABERLE, Peter. O Estado constitucional cooperativo. Rio de Janeiro: Renovar, 2007.

${ }^{143}$ Ensina RAÚl CERVINI et al que há "uma série de controles que derivam da própria norma internacional e principalmente de dentro do próprio sistema jurídico envolvido. Esses controles que se traduzem tanto em garantias para a soberania, como para as pessoas concernidas, se validam principalmente na ordem pública internacional" (Princípios da cooperação judicial penal internacional no Protocolo do Mercosul, cit., p. 123-124). Trata-se, aliás, de uma nova concepção do direito internacional incorporada pela Constituição Federal de 1988, ao consagrar o princípio de cooperação entre os povos para o progresso da humanidade (art. $4^{\circ}$, IX), da defesa da paz (art. $4^{\circ}$, VI) e da solução pacífica dos conflitos (art. $4^{\circ}$, VII).

${ }^{144}$ BECHARA, Fábio Ramazzini. Cooperação jurídica internacional em matéria penal: eficácia da prova produzida no exterior, cit., p. 52.

${ }^{145}$ BECHARA, Fábio Ramazzini. Cooperação jurídica internacional em matéria penal: eficácia da prova produzida no exterior, cit., p. 53.

${ }^{146}$ DELMAS-MARTY, Mireille. O direito penal como ética da mundialização, cit., p. 289.

${ }^{147}$ DELMAS-MARTY adverte, contudo, que esse direito penal mundial em formação representa uma ética ambígua e de aplicação variável. A ambiguidade do direito penal mundial reside em seu discurso "simultaneamente securitário e humanista", que tenta aliar a função instrumental do direito penal à sua função simbólica. No que toca à função instrumental do direito penal, costumeiro é o discurso da debilidade da cooperação internacional face à criminalidade transnacional. Na função simbólica, o direito
} 
Semelhantemente, CHERIF BASSIOUNI ensina haver uma interdependência entre os povos e as nações, construída a partir do aprimoramento das relações humanas e do desenvolvimento de novas fontes tecnológicas. Nesse cenário, é possível reconhecer a existência de uma consciência social mundial calcada sobre valores e expectativas compartilhadas, por meio da qual os membros da comunidade global agem em conformidade e sujeição a certos standards mínimos de conduta ${ }^{148}$.

Esse padrão ético universal dos direitos humanos (standards mínimos de conduta) integra normas de ius cogens, de caráter imperativo, que operam não somente a limitar a autodeterminação dos Estados, obrigando-os à adoção de um único modelo, mas a "fomentar a equivalência e a semelhança entre os sistemas" ${ }^{149}$. Busca-se, assim, um standard universal no tocante à proteção dos direitos humanos, que deve ser observado pelos Estados, mediante a integração harmoniosa desse standard com as respectivas ordens jurídicas internas.

A consolidação dos direitos humanos como normas de ius cogens e a incorporação harmoniosa desses padrões normativos humanitários aos ordenamentos jurídicos nacionais opera, de qualquer modo, como vetor de proteção do indivíduo contra a atuação estatal no processo cooperacional.

\subsection{Considerações finais}

Os tratados internacionais humanitários estabeleceram um padrão normativo, com standards mínimos de garantias fundamentais. Esse padrão normativo internacional acabou servindo de ponto de contato entre os ordenamentos jurídicos ${ }^{150}$.

\footnotetext{
penal mundial representa a afirmação e proteção de valores comuns à humanidade, vitimizada pela crescente criminalidade transnacional. Ao modelo que remete à função simbólica do direito penal, está intimamente ligada a criação dos Tribunais penais internacionais ad hoc e do Tribunal Penal Internacional, instituído pelo Tratado de Roma de 1998. No que se refere à ética de aplicação variável decorrente do direito penal mundial, DELMAS-MARTY aponta às possíveis imperfeições já manifestadas pelo direito penal mundial. Como exemplo, cite-se a coexistência de "ofensiva anti-TPI" da política estrangeira estadunidense ao lado do estímulo cada vez maior à jurisdição universal do juiz nacional, que, segundo a autora, "torna-se o emblema da ética a construir" (O direito penal como ética da mundialização, cit., p. 289-295). A esse respeito, v. V. MORO, Sérgio Fernando. Cooperação jurídica internacional em casos criminais: considerações gerais, cit.; DE SANCTIS, Fausto Martin. Crime organizado e lavagem de dinheiro: destinação de bens apreendidos, delação premiada e responsabilidade social. São Paulo: Saraiva, 2009.

${ }^{148}$ BASSIOUNI, Cherif. El derecho penal internacional: historia, objeto y contenido. Anuario de Derecho Penal y Ciencias Penales, Madrid: t. 35, fasc. 1, p. 5, jan./abr.1982.

${ }^{149}$ BECHARA, Fábio Ramazzini. Cooperação jurídica internacional em matéria penal: eficácia da prova produzida no exterior, cit., p. 56.

${ }^{150}$ BECHARA, Fábio Ramazzini. Cooperação jurídica internacional em matéria penal: eficácia da prova produzida no exterior, cit., p. 181.
} 
Malgrado nunca existirá perfeita identidade entre normas de cunho garantista, poderá ser alcançada a harmonização dos sistemas ao se reconhecer e ao se adotar esses standards de garantias no processo cooperacional. É necessário implementar instrumentos eficientes e ágeis de cooperação jurídica internacional dentro de um padrão normativo universal, assegurando-se ao concernido o devido processo cooperacional ${ }^{151}$.

Entendemos, por isso, que os vetores de eficiência do processo cooperacional encontram limite na medida de atuação dos vetores de garantia, atingindo o equilíbrio necessário, isto é, que não represente cooperar acima de qualquer custo nem permitir que a cooperação seja inviabilizada pela adoção cega das garantias do concernido ${ }^{152}$.

\footnotetext{
151 "Na atualidade, é importante conciliar a necessidade de instrumentos mais eficientes, porque menos morosos, menos formais, com a exigência de serem observadas as garantias universalmente consagradas. Ante a diversidade de ordenamentos, difícil querer identidade de disposições de cunho garantista, mas é mister que se imponha o respeito às garantias asseguradas em um padrão normativo universal" (FERNANDES, Antonio Scarance. O direito processual penal internacional, cit., p. 23).

${ }^{152}$ Defendem RAUl Cervini e JuARez TAVARES que o equilíbrio entre eficiência e garantismo seria a "funcionalidade legitimante da moderna cooperação internacional, a qual deve ser concebida frente a um Direito de raiz antropocêntrica e garantidor dos Direitos Humanos" (Princípios da cooperação judicial penal internacional no Protocolo do Mercosul, cit., p. 50). Semelhantemente, MiREILLE DELMAS-MARTY assevera que o direito penal possui em sua essência o que a autora denomina "dimensão ética", que é capaz de contribuir para o equilíbrio entre a globalização e a universalidade dos direitos humanos (O direito penal como ética da mundialização, cit., p. 288). Segundo o magistério de ADA PELlEGRINI GRINOVER, no esforço dos países na busca de um equilíbrio entre a obrigação de cooperar e o respeito às garantias fundamentais do homem, têm sido comuns cláusulas supostamente limitadoras da cooperação jurídica internacional em matéria penal, tais como: (i) cláusula que proíbe a entrega de pessoa na presença de riscos de discriminação ("cláusula francesa"); (ii) cláusula que evita a entrega da pessoa para ser submetida a tratamento desumano, degradante ou lesivo à integridade física; (iii) a negativa de entrega quando, pela condição de idade, saúde ou outras circunstâncias pessoais, é possível considerar a entrega incompatível com considerações humanitárias ("cláusulas humanitárias"); (iv) cláusulas que proíbem a submissão a tribunais de exceção ou a pena imposta por esses tribunais; (v) cláusulas que disciplinam de maneira diversa as medidas cautelares, reforçam a garantia jurisdicional, valorizam o contraditório e enaltecem o principio do ne bis in idem. A jurisprudência internacional tem influenciado as relações internacionais no que tange à cooperação jurídica em matéria penal, agindo como um "freio de emergência" (GRINOVER, Ada Pellegrini. Processo penal transnacional: linhas evolutivas e garantias processuais, cit., p. 40-83).
} 


\section{MEDIDAS CAUTELARES PATRIMONIAIS NO PROCESSO PENAL}

\subsection{Considerações iniciais}

Neste capítulo, trataremos das medidas cautelares patrimoniais no processo penal, com objetivo de identificar, ao final, os possíveis pontos de conflito entre diferentes modelos de medidas cautelares patrimoniais no âmbito da cooperação jurídica internacional em matéria penal.

Frise-se mais uma vez: o objetivo principal da dissertação é abordar o tema da cooperação jurídica internacional em matéria penal sob a perspectiva do devido processo legal e, a partir desse enfoque, estudar conflitos que eventualmente surgem a partir dos pedidos de assistência jurídica para o cumprimento de medida cautelar patrimonial. Assim, no presente capítulo, trataremos de aspectos importantes para a contextualização e delimitação do tema, mas sem qualquer pretensão de aprofundar o estudo acerca das medidas cautelares patrimoniais no processo penal.

Pois bem, a tutela cautelar atua a evitar a ocorrência de um dano jurídico, consistente na ineficácia ou inutilidade da prestação jurisdicional ${ }^{153}$ no período de transcurso processual ${ }^{154}$. Por meio da tutela cautelar, evita-se que o estado das coisas venham a se alterar durante a passagem do tempo necessário ao deslinde do processo, prejudicando a utilidade e eficácia do provimento judicial.

Segundo Roberto SANTOS BedAque, no intuito de assegurar o justo processo, existem técnicas processuais orientadas para garantir o aproveitamento e a utilidade da atuação jurisdicional e, assim, minorar os riscos de um desempenho meramente simbólico da ordem jurídica ${ }^{155}$.

\footnotetext{
${ }^{153}$ THEODORO JÚNIOR, Humberto. Processo cautelar. 19. ed. São Paulo: Livr. e Editora Universitária de Direito, 2000. p. 63.

${ }^{154}$ Também segundo HÉLIO TORNAGHI, a tutela cautelar "cifra-se em evitar o dano proveniente da morosidade (do processo)" (Instituições de processo penal. 2. ed. São Paulo: Saraiva, 1978. v. 3, p. 6).

${ }^{155}$ BEDAQUE, José Roberto dos Santos. Tutela cautelar e tutela antecipada: tutelas sumárias e de sistematização. 5. ed. São Paulo: Malheiros Ed., 2009. p. 122.
} 
Referidas técnicas processuais ${ }^{156}$ instrumentalizam-se através das tutelas sumárias, dentre as quais se situa a tutela cautelar.

Ensina BEDAQUE que a tutela cautelar é desempenhada por intermédio de medidas cautelares, que visam a garantir que o resultado do provimento final do processo possa ocorrer com certa dose de eficiência ${ }^{157}$. Trata-se, em suma, de providências urgentes, destinadas a assegurar que a decisão da causa, ao ser obtida, satisfaça o direito da parte e realize a função instrumental do processo, consistente em uma prestação jurisdicional justa ${ }^{158}$.

\subsection{Tutela cautelar no processo penal}

O Estado exerce a atividade jurisdicional através do processo, buscando atingir a solução mais justa ${ }^{159}$. O processo é instrumento indissociável do exercício da jurisdição ${ }^{160}$, pois é o meio de que se serve o Estado para satisfazer o direito à tutela jurídica a que fazem jus os cidadãos ${ }^{161}$.

Na esfera penal, o processo é a única instituição estatal que se reconhece como legítima para a imposição de pena ou medida de segurança ${ }^{162}$.

${ }^{156}$ Em semelhante visão, de tutela cautelar como "técnica processual", v. GOMES FILHO, Antônio Magalhães. Presunção de inocência e prisão cautelar. São Paulo: Saraiva, 1991. p. 55.

${ }^{157}$ BEDAQUE, José Roberto dos Santos. Tutela cautelar e tutela antecipada: tutelas sumárias e de sistematização, cit., p. 122.

${ }^{158}$ FERNANDES, Antonio Scarance. Processo penal constitucional. 6. ed. atual. rev. São Paulo: Ed. Revista dos Tribunais, 2010. p. 279.

159 “É o processo o palco no qual devem se desenvolver, em estruturação equilibrada e cooperadora, as atividades do Estado (jurisdição) e das partes (autor e réu). Nenhuma dessas atividades deve ser o centro, impondo-se sobre as outras. $\mathrm{O}$ excessivo realce à predominância da jurisdição sobre as partes é reflexo do valor dado ao intervencionismo estatal na sociedade e na vida dos indivíduos. Prestigiar a ação é ressaltar a atividade do autor em detrimento da atuação do Estado e da defesa. Colocar a defesa como a razão do processo é, também, o ponto de convergência e de irradiação. É nele e por meio dele que alguém pode pleitear a afirmação concreta de seu direito. É mediante o processo que o Juiz, como órgão soberano do Estado, exerce a sua atividade jurisdicional e busca, para o caso, a solução mais justa" (FERNANDES, Antonio Scarance. Processo penal constitucional, cit., p. 33).

${ }^{160}$ TUCCI, Rogério Lauria; DELMANTO JÚNIOR, Roberto. Sistematização das medidas cautelares processuais penais. Revista do Advogado, São Paulo, v. 24, n. 78, p. 112, set. 2004.

${ }^{161}$ THEODORO JÚNIOR, Humberto. Processo cautelar, cit., p. 41.

162“"Para que possa ser aplicada uma pena, não só é necessário que exista um injusto típico, mas também que exista previamente o devido processo penal. A pena não só é efeito jurídico do delito, senão é um efeito do processo; mas o processo não é efeito do delito, senão da necessidade de se impor a pena ao delito por meio do processo". Segundo o autor, a norma de Direito Penal é despida de eficácia direta, ou seja, "não tem atuação nem realidade concreta fora do processo correspondente". No direito privado, ao revés, suas "normas possuem uma eficácia direta, pois os particulares detêm o poder de praticar atos jurídicos e negócios jurídicos, de modo que a incidência das normas de direito material - sejam civis, comerciais etc. é direta". (LOPES JR., Aury. Introdução crítica ao processo penal: fundamentos da instrumentalidade constitucional. 4. ed. Rio de Janeiro: Lumen Juris, 2006. p. 2-3). 
A prática de um crime faz nascer a pretensão punitiva do Estado, consistente no poder-dever de, a tornar efetivo seu ius puniendi, exigir a submissão de quem cometeu o delito à sanção penal ${ }^{163}$. Impõe-se, para tanto, a necessária utilização do processo judicial para apurar a existência do delito e sancionar o respectivo autor.

O processo penal é meio instransponível à imposição da pena ou medida de segurança em decorrência da prática delituosa ${ }^{164}$. Trata-se do único instrumento ${ }^{165}$ adequado à efetivação do direito penal substantivo e à proteção das garantias individuais ${ }^{166}$. Assim, existe no processo penal uma instrumentalidade que é mais latente se comparada ao processo civil $^{167}$.

Ocorre que o processo, assim observa ANTÔNIO MAGALHÃES GOMES FILHO, é atividade que requer um desenvolvimento temporal ${ }^{168}$.

Como instrumento imprescindível à aplicação do direito material substantivo, o processo pressupõe, em sua essência, sequência de atos complexos que, no contexto do devido processo legal, servem de preparação ao provimento final ${ }^{169}$. Para que todos esses

\footnotetext{
${ }^{163}$ BADARÓ, Gustavo Henrique Righi Ivahy. Correlação entre acusação e sentença. 2. ed. São Paulo: Ed. Revista dos Tribunais, 2010. p. 69). O autor fala em duas pretensões distintas: a pretensão material, que é preexistente ao processo, consistente no poder de exigir de outrem alguma prestação positiva ou negativa; e uma pretensão processual, inerente ao processo, que é veiculada em juízo através do direito de ação, independentemente do direito material que fundamente o pedido do autor. O termo "pretensão punitiva" faz referência à pretensão material e não à pretensão processual, que é o objeto do processo (op. cit., p. 70-71).

${ }^{164}$ Opera em favor do cidadão o direito constitucionalmente reconhecido à tutela jurisdicional ("a lei não excluirá da apreciação do Poder Judiciário lesão ou ameaça a direito", art. $5^{\circ}$, XXXV, da Constituição Federal). Especialmente na seara penal, o direito à tutela jurisdicional ganha firmes reforços face ao nulla poena sine iudicio, segundo o qual a sanção penal somente pode ser aplicada pelos órgãos jurisdicionais, por meio de um instrumento adequado, que é o processo. Nesse sentido: TUCCI, Rogério Lauria. Direitos e garantias individuais no processo penal brasileiro. 2. ed. São Paulo: Ed. Revista dos Tribunais, 1993. p. 27-28.

${ }^{165}$ “(...) não devem existir pudores de que o processo é um instrumento” (LOPES JR., Aury. Introdução crítica ao processo penal: fundamentos da instrumentalidade constitucional, cit., p. 2-6).

${ }^{166 ، " C o m ~ e f e i t o, ~ o ~ D i r e i t o ~ P e n a l ~ n a ̃ o ~ p o d e ~ s e r ~ a t u a d o ~ d i r e t a ~ e ~ p r o n t a m e n t e, ~ s e n d o ~ i n a d m i s s i ́ v e l ~ c o n c r e t i z a ́-l o ~}$ sem o respectivo processo judicial. Neste sentido, o processo penal revela-se como o instrumento adequado e necessário para a efetivação do direito penal substantivo, bem como para a proteção dos direitos e garantias individuais" (GONÇALVES, Marianna Moura. Prisão e outras medidas cautelares pessoais à luz da proporcionalidade. 2001. Dissertação (Mestrado) - Faculdade de Direito da Universidade de São Paulo, São Paulo, 2001. p. 135).

167" A instrumentalità do processo penal reside no fato de que a norma penal apresenta, quando comparada com outras normas jurídicas, a característica de que o preceito tem como conteúdo um determinado comportamento proibido ou imperativo e a sanção tem como destinatário aquele poder do Estado, que é chamado a aplicar a pena. Não é possível a aplicação da reprovação sem o prévio processo, nem mesmo no caso de consentimento do acusado, pois ele não pode se submeter voluntariamente à pena, senão por meio de um ato judicial (nulla poena sine iudicio). Essa particularidade do processo penal demonstra que seu caráter instrumental é mais destacado do que o do processo civil" (LOPES JR., Aury. Introdução crítica ao processo penal: fundamentos da instrumentalidade constitucional, cit., p. 8).

${ }^{168}$ GOMES FILHO, Antônio Magalhães. Medidas cautelares e princípios constitucionais. In: FERNANDES, Og (Coord.). Medidas cautelares no processo penal: prisões e suas alternativas - comentários à Lei 12.403, de 04.05.2011. São Paulo: Ed. Revista dos Tribunais, 2011. p. 16.

${ }^{169}$ GOMES FILHO, Antônio Magalhães. Medidas cautelares e princípios constitucionais, cit., p. 16.
} 
atos tomem seu devido curso, rumo à consecução do exercício jurisdicional, opera-se um lapso temporal que não pode ser ignorado.

Desse modo, entre a data de ocorrência dos fatos delituosos e o provimento judicial final, poderão transcorrer facilmente meses ou até anos, trazendo risco de que o estado das coisas venha a sofrer alterações que possam ameaçar a eficácia da intervenção estatal na aplicação da norma penal ${ }^{170}$.

Com efeito, imagine-se o réu que consiga empreender fuga no decorrer da instrução processual penal ou logo após a sentença penal condenatória. A fuga, em si, não inviabiliza o processo, mas lhe extirpa grande parte da utilidade e eficácia, na medida em que, foragido o condenado, fica prejudicada a execução penal.

Situação semelhante ocorre se os bens do acusado forem dispersados, dilapidados ou restarem desvalorizados durante o processo. Neste caso, pouca eficácia terá a execução quanto aos efeitos automáticos da condenação penal, no que diz respeito à perda dos bens obtidos com os proventos do crime e à obrigação de reparar o dano causado com a prática delituosa ${ }^{171}$.

Na mesma toada, as provas também ficam expostas à ação voraz do tempo ${ }^{172}$.

Partindo dos estudos de PIERo CALAMANDREI ${ }^{173}$, a doutrina italiana costuma identificar duas ordens de riscos intrínsecos ao processo.

O "perigo de infrutuosidade" é o risco de ameaça à utilidade e à eficácia da tutela jurisdicional decorrente do período necessário ao alcance do pronunciamento final. Ocorre que a demora no regular desenvolvimento do processo - a prolongar em demasia a

\footnotetext{
${ }^{170}$ GOMES FILHO, Antônio Magalhães. Medidas cautelares e princípios constitucionais, cit., p. 16. No mesmo sentido, ensina PIERo CALAMANDREI: "affinché il provvedimento definitivo nasca colle maggiori garanzie di giustizia, esso dev'esser preceduto dal regolare e mediato svolgimento di tutta una serie di attività, al compimento delle quali `e necessario un periodo, spesso non breve, di attesa; ma questa mora indispensabile al compimento dell'ordinario inter processuale, rischia di rendere praticamente inefficace il provvedimento definitivo, il quale par destinato, per amor di perfezione, a giunger troppo tardi, come la medicina lungamente elaborata per un ammalato già morto." (Introduzione allo studio sistematico dei provvedimenti cautelari. Padova: CEDAM, 1936. p. 19).

${ }^{171}$ Artigo 91 do Código Penal Brasileiro: “Art. 91 - São efeitos da condenação: I - tornar certa a obrigação de indenizar o dano causado pelo crime; II - a perda em favor da União, ressalvado o direito do lesado ou de terceiro de boa-fé: a) dos instrumentos do crime, desde que consistam em coisas cujo fabrico, alienação, uso, porte ou detenção constitua fato ilícito; b) do produto do crime ou de qualquer bem ou valor que constitua proveito auferido pelo agente com a prática do fato crimino".

${ }^{172}$ CARNELUTTI, Francesco. Lecciones sobre el proceso penal. Buenos Aires: Ediciones Jurídicas EuropaAmérica, 1950. p. 71.

${ }^{173}$ CALAMANDREI, Piero. Introduzione allo studio sistematico dei provvedimenti cautelari, cit.
} 
satisfação do direito discutido em juízo - também já seria capaz de causar sérios danos ao seu titular. Daí, fala-se em um segundo risco, o "perigo de tardividade".

Ora, o Estado tomou para si a exclusividade de solucionar conflitos. Na esfera penal, também acumula o monopólio de aplicar a norma penal substantiva, senão mediante o pronunciamento judicial desenvolvido em devido processo legal. É imperioso que a solução judicial revele-se efetivamente justa, útil e eficaz ${ }^{174}$.

A tutela cautelar no processo penal serve para superar - ou, ao menos, minimizar - esses riscos inerentes ao processo ${ }^{175}$. FRANCESCO CARNELUTTI ensinava ser a função da tutela cautelar"176 "assegurar os meios ou os resultados do processo" 177.

\subsection{Medidas cautelares patrimoniais no processo penal}

A tutela cautelar no processo penal se instrumentaliza através de medidas cautelares.

Medidas cautelares ${ }^{178}$ servem para superar o risco de prejuízo à eficiência e à eficácia do provimento final em virtude do desenvolvimento temporal decorrido no

\footnotetext{
${ }^{174}$ Com efeito, não basta ao Estado assumir o monopólio da Justiça através da jurisdição. A função jurisdicional "não se propõe lograr fins simplesmente teóricos, senão alcançar resultados positivos e tangíveis, o que, todavia, nem sempre é possível obter com os processos de cognição e execução" (THEODORO JÚNIOR, Humberto. Processo cautelar, cit., p. 56).

${ }^{175}$ É da lavra de ANTÔNIO MAGALHÃES GOMES FILHO o entendimento segundo o qual "a cautelaridade constituiu uma técnica processual destinada a superar os riscos inerentes à própria estrutura do processo; esta, ao estabelecer dilações para a correta averiguação da situação trazida ao conhecimento do órgão judiciário, assegurando especialmente a participação dos interessados na formação do provimento desejado, traz em si o perigo de que, ao final, o estado das coisas tenha sofrido alterações substanciais capazes de tornar absolutamente ineficaz a intervenção estatal para solução do conflito" (Presunção de inocência e prisão cautelar, cit., p. 55). No mesmo sentido: BEDAQUE, José Roberto dos Santos. Tutela cautelar e tutela antecipada: tutelas sumárias e de sistematização, cit., p. 122.

${ }^{176}$ ROGÉRIO LAURIA TUCCI et. al. reconhece a existência de uma "função jurisdicional cautelar" na esfera processual penal, "decorrente do dever de assegurar o direito, exercida permanentemente pelo Juiz, uma vez incoada a persecução penal (tanto na fase pré-processual quanto na processual)" (Sistematização das medidas cautelares processuais penais, cit., p. 112).

${ }^{177}$ CARNELUTTI, Francesco. Lecciones sobre el proceso penal, cit., p. 72.

${ }^{178}$ A doutrina costuma distinguir provimento cautelar (a própria decisão que determina ou homologa a imposição de medida cautelar), providência cautelar (ato em que se materializa cada uma das medidas cautelares previstas em lei) e diligência cautelar (ato ou conjunto de atos praticados em cumprimento à mesma [providência], normalmente fora da sede do Juízo, que é efetivada para cumprimento ao provimento cautelar e em conformidade com o estipulado na providência cautelar) (TUCCI, Rogério Lauria; DELMANTO JÚNIOR, Roberto. Sistematização das medidas cautelares processuais penais, cit., p. 115); no mesmo sentido: v. GIMENES, Marta Cristina Cury Saad. As medidas assecuratórias do Código de Processo Penal como forma de tutela cautelar destinada à reparação do dano causado pelo delito. 2007. Tese (Doutorado) - Faculdade de Direito da Universidade de São Paulo, São Paulo, 2007. p. 36).
} 
processo $^{179}$. O tempo necessário ao escopo do processo gerar risco de a situação venha a se alterar ${ }^{180}$, por isso são necessárias medidas que busquem assegurar o resultado útil e eficaz ao processo.

No processo penal, as medidas cautelares podem recair sobre pessoas (prisão preventiva, prisão temporária e medidas cautelares alternativas da prisão), sobre bens (medidas cautelares patrimoniais), ou para fins probatórios (meios de obtenção de prova, como a busca e apreensão, e medidas antecipatórias de provas).

Medidas cautelares patrimoniais asseguram resultado útil a eventual e futura decisão penal condenatória no que toca ao efeito automático de tornar certa a obrigação de reparar o dano e ao efeito de perdimento dos instrumentos do crime e dos bens obtidos com os proventos da infração.

Para garantir eficácia e utilidade à sentença penal condenatória, por vezes se torna necessária a imposição de medidas cautelares sobre os bens do acusado, impedindo que sejam desviados, desvalorizados ou dilapidados durante o período que perdurar o processo ${ }^{181}$.

\footnotetext{
${ }^{179}$ HéLIO TORNAGHI associava a tutela cautelar à necessidade de afastar o risco de dano causado pelo tempo que perdura o processo: "as providências assecuratórias se destinam a prevenir, com a necessária urgência, o dano que resultaria da demora da providência definitiva. Não é a prevenção de qualquer dano que as faz surgir, mas apenas a do prejuízo que haveria com a tardança da providência definitiva" (Instituições de processo penal, cit., v. 3, p. 6). Conforme ANTÔNIO SCARANCE FERNANDES, "no intervalo entre o nascimento da relação jurídica processual e a obtenção do provimento final, existe o risco de sucederem eventos que comprometam a atuação jurisdicional ou afetem profundamente a eficácia e utilidade do julgado. Há, então, a necessidade de medidas cautelares, que eliminem ou amenizem esse perigo" (Processo penal constitucional, cit., p. 279). Na mesma toada, ensina ElOISA DE SOUSA ARRUDA: "A dinâmica do processo, por vezes, em face do princípio normal desenrolar de seu atos, pode resultar na inocuidade da decisão definitiva. Assim, apesar de obtida a sentença que, a princípio, poderia servir à satisfação de interesses, como o da vítima na reparação do dano ex delicto, não têm como ser atendidos, em face de circunstâncias ocorridas no curso da ação penal (por exemplo, a total dilapidação, pelo réu, de seu patrimônio. Por isso mesmo, na disciplina da aplicação do direito material, muitas vezes o legislador vê-se compelido a admitir providências cautelares (...), com a finalidade de assegurar os meios para que esse provimento definitivo possa ser conseguido e, principalmente, possa ser eficaz" (As medidas cautelares reais no processo penal brasileiro. MPMG Jurídico, Belo Horizonte, v. 1, n. 3, p.52-53, dez./jan. 2005/2006). Trilhando o mesmo entendimento, LARISSA LEITE entende por medidas processuais de urgência os "mecanismos destinados a evitar o perecimento de direitos em situações especiais, nas quais o tempo demandado para a conclusão do processo, por suas vias ordinárias, represente risco (grave e concreto)." (Medidas patrimoniais de urgência no processo penal: implicações teóricas e práticas. Rio de Janeiro: Renovar, 2011. p. 99).

${ }^{180}$ BADARÓ, Gustavo Henrique Righi Ivahy. Medidas cautelares patrimoniais no processo penal. In: VILARDI, Celso Sanchez; PEREIRA, Flávia Rahal Bresser; DIAS NETO, Theodomiro (Coords.). Direito penal econômico: crimes econômicos e processo penal. São Paulo: Saraiva, 2008. p. 175.

${ }^{181} \mathrm{~A}$ presente dissertação põe foco sobre as medidas cautelares patrimoniais cumpridas no contexto da cooperação jurídica internacional em matéria penal, ou seja, quando a medida assecuratória se destine a garantir bens localizados em domínio territorial de país diverso daquele onde tramita o processo principal, o processo-crime cujos efeitos - sobretudo de eventual sentença penal condenatória - se pretende assegurar. Para essa finalidade, vários tratados, quer no plano multilateral, quer no plano bilateral, operam como fonte jurídica ao cumprimento de medidas cautelares patrimoniais em cooperação jurídica internacional. Tais tratados possibilitam até mesmo o emprego de instrumentos mais ágeis de cooperação jurídica internacional, conforme será tratado no capítulo III.
} 


\subsubsection{Finalidades das medidas cautelares patrimoniais no processo penal}

Na esfera civil, o ato ilícito faz nascer, à pessoa prejudicada, o direito de exigir a reparação dos danos sofridos. O mesmo ocorre como efeito do ilícito penal se, em consequência deste, houver dano a reparar ${ }^{182}$. Incide, portanto, responsabilidade civil quando estão presentes conduta, dano e nexo de causalidade entre ambos, ainda que o fato configure ilícito de natureza múltipla, ou seja, também configure crime ${ }^{183}$.

A responsabilidade civil e a responsabilidade penal proporcionam respectivas ações, uma tendente à reparação, outra, à punição. Em linhas gerais, é possível ordenar em três grupos as legislações que estabelecem sistemas de coordenação entre as esferas civil e penal: a) sistema da separação ou independência das esferas, pelo qual o procedimento penal exerce nenhuma ou limitada influência na seara civil; b) sistema da confusão, pelo qual uma mesma ação de natureza múltipla, civil e penal, conduziria concomitantemente à aplicação da pena e à reparação do dano causado pelo crime; c) sistema da solidariedade, unidade ou interdependência das instâncias, pelo qual a reparação do dano e a aplicação da pena são obtidos por meio de duas ações, civil e penal, ajuizadas em um único processo e julgadas simultaneamente pelo mesmo juiz penal; d) sistema da livre escolha, que estabelece a faculdade de cumular as ações civil e penal no mesmo juízo criminal, ou fazêlas correr separadamente, em suas respectivas instâncias ${ }^{184}$.

O sistema vigente no Brasil é o da independência, porque não há cumulação obrigatória, nem facultativa, de ação civil perante o juízo criminal ${ }^{185}$. A responsabilidade civil é independente da criminal, regra estabelecida no art. 935 do Código Civil, o que

\footnotetext{
${ }^{182}$ Pode haver crime sem que haja dano. Como ensina MARTA CRISTINA CURY SAAD GIMENES, existe: crime que não configura ilícito penal; crime que também configura ilícito civil, mas não produz dano; e crime que constitui ilícito civil e causa dano passível de ressarcimento (GIMENES, Marta Cristina Cury Saad. As medidas assecuratórias do Código de Processo Penal como forma de tutela cautelar destinada à reparação do dano causado pelo delito, cit., p. 13).

${ }^{183}$ GIMENES, Marta Cristina Cury Saad. As medidas assecuratórias do Código de Processo Penal como forma de tutela cautelar destinada à reparação do dano causado pelo delito, cit., p. 33.

${ }^{184}$ GIMENES, Marta Cristina Cury Saad. As medidas assecuratórias do Código de Processo Penal como forma de tutela cautelar destinada à reparação do dano causado pelo delito, cit., p. 33. No mesmo sentido, v. FERNANDES, Antonio Scarance. O papel da vítima no processo criminal. São Paulo: Malheiros Ed., 1995; ASSIS, Araken de. A eficácia civil da sentença penal. São Paulo: Ed. Revista dos Tribunais, 1993.

${ }^{185}$ A exposição de motivos do Código de Processo Penal, item 6, estabelece: "O projeto, ajustando-se ao Código Civil e ao novo Código Penal, mantém a separação entre a ação penal e a civil ex delicto, rejeitando o instituto ambíguo da constituição de 'parte civil' no processo penal. A obrigação de reparar o dano resultante do crime não é uma consequência de caráter penal, embora se torne certa quando haja sentença condenatória no juízo criminal. A invocada conveniência prática da economia de juízo não compensa o desfavor que acarretaria ao interesse de repressão a interferência de questões de caráter patrimonial, no curso do processo penal...".
} 
implica dizer: nada impede o ajuizamento de ação civil, com vistas a indenização decorrente do crime, antes ou no curso da ação penal contra o pretenso autor ${ }^{186}$.

Embora haja a independência das responsabilidades civil e penal, no sistema brasileiro isto ocorre de maneira relativa, na medida em que se reconhece a influência da coisa julgada penal sobre a esfera civil.

A sentença penal condenatória transitada em julgado gera como principal efeito o de sujeitar o agente à pena que lhe foi imposta. Paralelamente, incidem efeitos de ordem extrapenal, previstos no artigo 91 do Código Penal brasileiro ${ }^{187}$, também chamados efeitos automáticos da condenação ${ }^{188}$, quais sejam: a) a obrigação de reparar o dano causado pelo crime e b) a perda, em favor da União, respeitado o direito do lesado e de terceiro de boa fé, do produto do crime ou de qualquer bem ou valor que constitua proveito auferido pelo agente com a prática do fato criminoso ${ }^{189}$.

As medidas cautelares patrimoniais, no escopo da tutela cautelar no processo penal, asseguram resultado útil de eventual decisão condenatória transitada em julgado no que toca a esses efeitos automáticos da condenação, quais sejam, tornar certa a obrigação de reparar o dano e perdimento do instrumento do crime e dos proventos da infração.

As medidas cautelares patrimoniais não antecipam os efeitos automáticos da sentença penal condenatória transitada em julgado, mas, ao contrário, asseguram-nos pelo tempo que perdure o processo.

\footnotetext{
${ }^{186}$ GIMENES, Marta Cristina Cury Saad. As medidas assecuratórias do Código de Processo Penal como forma de tutela cautelar destinada à reparação do dano causado pelo delito, cit., p. 15-21.

187““Art. 91 - São efeitos da condenação: I - tornar certa a obrigação de indenizar o dano causado pelo crime; II - a perda em favor da União, ressalvado o direito do lesado ou de terceiro de boa-fé: a) dos instrumentos do crime, desde que consistam em coisas cujo fabrico, alienação, uso, porte ou detenção constitua fato ilícito; b) do produto do crime ou de qualquer bem ou valor que constitua proveito auferido pelo agente com a prática do fato crimino".

${ }^{188}$ GIMENES, Marta Cristina Cury Saad. As medidas assecuratórias do Código de Processo Penal como forma de tutela cautelar destinada à reparação do dano causado pelo delito, cit., p. 33.

${ }^{189}$ No Brasil, a obrigação de reparar o dano em decorrência de ilícito penal e o perdimento de bens tem matriz constitucional, assim prevendo a Constituição Federal, em seu art. $5^{\circ}$, inciso LXV, que "nenhuma pena passará da pessoa do condenado, podendo a obrigação de reparar o dano e a decretação do perdimento de bens ser, nos termos da lei, estendidas aos seus sucessores e contra eles executados até o limite do valor do patrimônio transferido".
} 


\subsubsection{Assegurar a reparação do dano causado pelo delito}

Todo crime constitui uma ofensa ${ }^{190}$ a interesse ou bem juridicamente tutelado.

Segundo MagalHãES NoronHA, a prática delituosa acarreta "geralmente uma lesão que pode ser efetiva ou potencial e que atinge o titular daquele bem jurídico ou o sujeito passivo do delito"191. NELSON HUNGRIA, no mesmo sentido, dizia que "a ofensa pertence à natureza intrínseca do crime, coexistindo sempre com este”. Já a consequência nociva do crime é o dano, isto é, o prejuízo - não penas patrimonial, mas também moral que dele deriva ${ }^{192}$.

Como assevera GIMENES, ofensa e dano são conceitos que não se confundem. Ofensa é a agressão a interesse protegido pelo direito, que pode se dar pela lesão ou pela colocação em perigo. A ofensa é intrínseca ao delito, sendo o conteúdo do crime. O dano, por sua vez, é elemento extrínseco ao ilícito e, portanto, eventual. Cuida o dano de elemento acidental do ilícito, que pode subsistir com ou sem dano ${ }^{193}$.

Em outros dizeres, se o crime pressupõe ofensa a bem jurídico protegido, pode ocorrer crime mesmo sem haver dano algum. Porém, se da prática delituosa advém dano, o ato ilícito (decorrente do crime) gera, aos prejudicados, o direito de exigir a reparação civil dos prejuízos sofridos.

O dano causado pelo delito pode ser tanto de ordem patrimonial, consistente na perda, destruição ou deterioração de algum bem inserido no patrimônio de alguém, quanto moral, quando o ilícito afeta bens relacionados com a personalidade ${ }^{194}$.

Embora a ofensa seja essencialmente irreparável ${ }^{195}$, o dano pode ser objeto de responsabilização no âmbito civil. A responsabilidade civil pelo dano (patrimonial ou moral)

\footnotetext{
${ }^{190}$ No entendimento de NELSON HUNGRIA, “ofensa é a agressão do interesse juridicamente protegido (lesão ou perigo)" (Comentários ao Código Penal. Rio de Janeiro: Forense, 1942. v. 2, p. 461).

${ }^{191}$ NORONHA, Edgard Magalhães. Direito penal. 14. ed. São Paulo: Saraiva, 1977. v. 1, p. 318.

${ }^{192}$ HUNGRIA, Nelson. Comentários ao Código Penal, cit., p. 461.

${ }^{193}$ GIMENES, Marta Cristina Cury Saad. As medidas assecuratórias do Código de Processo Penal como forma de tutela cautelar destinada à reparação do dano causado pelo delito, cit., p. 11. Nesse sentido: "Occorre non confondere l'offesa con il danno: la prima `e nozione penalistica e indica la lesione del bene giuridico che caratterizza nella sua essenza il reato; la seconda 'e la conseguenza svantaggiosa che, pur ricollegandosi al reato, contraddistingue i profili civilista dell'illecito." (PISANI, Mario et al. Manuale di procedura penale. Bologna: Monduzzi, 1994. p. 114).

${ }^{194}$ ASSIS, Araken de. Liquidação do dano. In: MENDES, Gilmar Ferreira; STOCO, Rui (Orgs.). Atos, fatos, negócios jurídicos e bens. São Paulo: Ed. Revista dos Tribunais, 2001. (Coleção doutrinas essenciais: direito civil, parte geral; v. 4). p. 573.

${ }^{195}$ HUNGRIA, Nelson. Comentários ao Código Penal, cit., p. 461.
} 
visa a repor as coisas no estado anterior ao ato que lhe deu causa ${ }^{196}$, podendo dar-se pela reparação (restituição) ou pela indenização (pagamento do equivalente pecuniário ao dano) ${ }^{197}$.

A ocorrência de um delito pode acarretar dano patrimonial ou moral, ambos passíveis de responsabilização no âmbito civil, quer para restituir um bem subtraído ou lesado, quer para condenar o autor ao pagamento de valor equivalente ao transtorno moral provocado. Da prática do ilícito penal, nasce na maioria das vezes ${ }^{198}$, assim, uma pretensão de ressarcimento ${ }^{199}$.

Com efeito, estabelece o artigo 91, inciso I, do Código Penal brasileiro que a condenação criminal tem o efeito de "tornar certa a obrigação de indenizar o dano causado pelo crime". Também é previsto no Código de Processo Penal, artigo 387, inciso IV (com as alterações introduzidas pela Lei n. 11.719/2008) que o Juiz, ao proferir sentença penal condenatória, "fixará valor mínimo para reparação dos danos causados pela infração, considerando os prejuízos sofridos pelo ofendido".

Ademais, prevê o art. 63 do Código de Processo Penal: "Transitada em julgado a sentença condenatória, poderão promover-lhe a execução, no juízo cível, para o efeito da reparação do dano, o ofendido, seu representante legal ou seus herdeiros”. Na sequência, dispõe o art. 64 do mesmo codex: "sem prejuízo do disposto no artigo anterior, a ação para ressarcimento do dano poderá ser proposta no juízo cível, contra o autor do crime e, se for o caso, contra o responsável civil" ${ }^{200}$.

Na lição de Miguel REALE JÚNIOR, o trânsito em julgado da sentença penal condenatória serve de título executivo judicial na esfera civil, tornando firme a obrigação

\footnotetext{
${ }^{196}$ ASSIS, Araken de. Liquidação do dano, cit., p. 575.

${ }^{197}$ REALE JÚNIOR, Miguel. Instituições de direito penal: parte geral, cit., p. 474.

${ }^{198}$ Importante registrar: nem sempre a prática de um delito ocasiona um dano plausível de reparação. A reparação de danos somente tem lugar com a prática de crimes nos quais haja uma vítima determinada e danos cujo valor seja possível mensurar, em termos financeiros, ou seja, quando os bens jurídicos tutelados se mostram tangíveis, passíveis de reparação, como, por exemplo, nos crimes patrimoniais. Nesse sentido: TOURINHO FILHO, Fernando da Costa. Processo penal. 34. ed. São Paulo: Saraiva, 2012. v. 2, p. 24.

${ }^{199}$ TOURINHO FILHO, Fernando da Costa. Processo penal, cit., p. 22. Estabelece o Código Civil, em seu artigo 186: "aquele que por ação ou omissão voluntária, negligência ou imprudência violar direito e causar dano a outrem, ainda que exclusivamente moral, comete ato ilícito". Em complementação, o artigo 927 do mesmo codex prevê: "aquele que por ato ilícito causar dano a outrem fica obrigado a repará-lo".

${ }^{200}$ Segundo GUSTAVO HENRIQUE RIGHI IVAHY BADARÓ, a "restituição" (da res furtiva, por exemplo) é a maneira mais simples de satisfação do dano; o "ressarcimento" compreende o pagamento dos danos patrimoniais resultantes do crime (dano emergente e lucro cessante), enquanto que a "reparação" diz respeito ao dano não material (dano moral). Por fim, "indenização" é a compensação constitucionalmente assegurada (art. $5^{\circ}, \mathrm{LXXV}, \mathrm{CF}$ ) do ato ilícito praticado pelo Estado contra o particular. Segundo o autor, o Código de Processo Penal pátrio, embora não empregue a terminologia mais apropriada, faz expressa referência a restituição (art. 119), ressarcimento (art. 64), reparação (art. 63), indenização (art. 630, caput) (Medidas cautelares patrimoniais no processo penal, cit., p. 174).
} 
do réu de indenizar a vítima a título de compensação pelo dano sofrido com o delito. Sendo indiscutível a questão de mérito, pois já decidida em definitivo na esfera penal, resta verificar apenas na seara civil se houve dano patrimonial e/ou moral, bem como quantificar o valor da indenização ${ }^{201}$.

Diferente de outras legislações em que se admite atuação da parte civil na ação penal, permitindo-se a satisfação do dano na própria esfera penal ${ }^{202}$, o legislador pátrio garantiu o direito à vítima de, proferida sentença penal condenatória e esta transitando em julgado, exigir, perante o Juízo cível, a reparação do dano sofrido por meio de ação civil de execução. A sentença penal condenatória transitada em julgado valerá nesse caso como título certo e líquido ${ }^{203}$, sobretudo quanto àquele mínimo fixado pelo juiz criminal ${ }^{204}$.

${ }^{201}$ REALE JÚNIOR, Miguel. Instituições de direito penal: parte geral, cit., p. 473. Estabelece o artigo 935 do Código Civil que "a responsabilidade civil é independente da criminal, não se podendo questionar mais sobre a existência do fato, ou sobre quem seja o seu autor, quando estas questões se acharem decididas no juízo criminal". Assim, a apuração da responsabilidade civil pode ocorrer separada e concomitantemente à ação penal, mas, sobrevindo sentença penal condenatória transitada em julgado, esta servirá como título executivo no Juízo cível. No mesmo sentido, "A sentença condenatória faz coisa julgada no cível; quer dizer que não mais se pode indagar da procedência ou improcedência da condenação. Dita sentença vale como título executório, não obstante não conter a obrigação expressa de o condenado reparar o dano, pois se completa com mandamentos legais, como os arts. 159 e 1.525 do Código Civil, 63 do Código de Processo Penal e 74 do Código Penal" (NORONHA, Edgard Magalhães. Direito penal, cit., p. 319).

${ }^{202}$ Admitem o ingresso na ação penal, como parte civil, da vítima ou pessoa prejudicada pelo crime (ou seu representante), por exemplo, Portugal, Itália e Chile. Nestes países, a responsabilidade civil e penal são apuradas em um mesmo processo ou em processos diversos, mas que correm unidos e concomitantes sob a presidência de um Juiz comum. No Brasil, o Anteprojeto de Reforma do Código de Processo Penal (convertido no Projeto de Lei n. 156/2009, do Senado) prevê sistema muito semelhante. Referindo-se particularmente ao contexto chileno, JUAN YAÑEZ M. critica tal sistema. Segundo o autor, é perceptível um descompasso entre a responsabilidade penal e a responsabilidade civil no processo penal, na medida em que "a preocupação maior do legislador tem sido orientada a perseguir a responsabilidade criminal de um sujeito que afetou um bem jurídico tutelado pela lei penal". Ademais, o aumento no rigor das penas também influiu sobre os valores relativos às penas pecuniárias, logo, enquanto muitas vítimas acabam não recebendo reparação civil alguma ao final do processo, em contrapartida a conversão das multas em favor do Fisco faz com que o Estado seja o maior beneficiário com a prática delituosa: "à luz dessas normas, podemos sinceramente pensar que o legislador não considerou a situação da vítima e apenas se preocupou com o Fisco, quando deveria ter em conta as responsabilidades civis decorrentes do delito". Por consequência, a vítima foi colocada em profunda desvantagem. Deve ingressar com a ação civil na esfera penal para cumprir os prazos preclusivos e, tendo de suportar um extenso processo penal, se não requerer medidas cautelares destinadas a assegurar futura responsabilidade civil do agente ou, mesmo as tendo pedido, elas mostrarem-se insuficientes, sua pretensão civil poderá não ser satisfeita. E ao final do processo, diante de sentença penal condenatória com imposição de pena pecuniária, poderá ser impedido de receber a indenização a que tem direito diante das dívidas "preferenciais" do infrator. Tradução livre (Medidas cautelares reales. In: ALVEAR V., María Soledad (Coord.). El nuevo proceso penal chileno. Concepción: Impresos Andalién, 2000. p. 119-121).

${ }^{203}$ TOURINHO FILHO, Fernando da Costa. Processo penal, cit., p. 59.

${ }^{204}$ Caso não seja estipulado na sentença penal condenatória um valor mínimo a título de reparação do dano, a execução na esfera cível não prescindirá de uma fase prévia de liquidação, destinada a fixar o quantum debeatur. A respeito da liquidação do dano decorrente de ato ilícito, v. CARVALHO, Olímpio. Reparação de danos provenientes de atos ilícitos. In: MENDES, Gilmar Ferreira; STOCO, Rui (Orgs.). Atos, fatos, negócios jurídicos e bens. São Paulo: Ed. Revista dos Tribunais, 2001. p. 573. (Coleção doutrinas essenciais: direito civil, parte geral; v. 4). 
Em vista do risco de deterioração do patrimônio do acusado durante o tempo em que perdurar o processo, medidas cautelares patrimoniais podem ser requeridas pela vítima ou por quem a represente perante o Juízo penal, visando a assegurar a eficácia dos efeitos do processo penal e, consequentemente, a garantir futura e eventual satisfação do dano na esfera civil em caso de decreto condenatório penal definitivo.

\subsubsection{Assegurar a perda do produto ou provento do crime}

Outro efeito automático da sentença penal condenatória é a perda, em favor da União, ressalvado o direito do lesado ou terceiro de boa-fé, dos instrumentos do crime ou de bens e valores obtidos pelo agente com os proventos auferidos com a prática do fato criminoso - os produtos do crime (art. 91, II, "a" e “b”, do Código Penal) ${ }^{205}$. Trata-se do confisco dos instrumentos e produtos do crime, em decorrência de sentença condenatória definitiva, o que não se confunde com a pena de confisco.

Mediante o confisco, observa CEZAR RoBerto BitenCourt, o Estado "visa a impedir que instrumentos idôneos para delinquir caiam em mãos de certas pessoas, ou que o produto do crime enriqueça o patrimônio do delinquente, constituindo medida salutar, saneadora e moralizadora",206.

São instrumentos do crime os materiais que serviram de alguma forma à execução do delito.

Consideram-se produtos do crime para efeito de confisco materiais, bens ou valores adquiridos diretamente com o crime (res furtiva) ou por sucessiva especificação, ou conseguidos através de alienação (dinheiro da venda do produto direto do crime) ou, ainda, fabricados como consequência do próprio fato delituoso (a moeda falsa). Encontra-

\footnotetext{
${ }^{205} \mathrm{Na}$ lição de ROBERTO LYRA, “Produtos do crime (producta sceleris) são as coisas adquiridas diretamente com o crime (coisa roubada), ou mediante sucessivas especificações (jóia feita com o ouro roubado), ou conseguidas mediante alienação (dinheiro da venda do objeto roubado) ou criadas com o crime (moeda falsa). Também se inclue (sic) no confisco outro qualquer bem ou valor, que importe provento, desde que haja sido auferido pelo agente, e não por terceiros, com a prática do crime. Assim: o preço deste, os bens economicamente apreciáveis dados ou prometidos ao agente para que cometa o crime, a contraprestação que corresponde à prestação da atividade criminosa, a retribuição desta..." (Comentários ao Código Penal. Rio de Janeiro: Forense, 1942. v. 2, p. 463).

${ }^{206}$ BITENCOURT, Cezar Roberto. Tratado de direito penal: parte geral. 16. ed. São Paulo: Saraiva, 2011. v. 1, p. 771.
} 
se igualmente incluído qualquer outro bem ou valor que importe proveito com a prática do crime, desde que tenha sido auferido pelo agente e não por terceiros ${ }^{207}$.

Importante ressaltar que o legislador pátrio pretendeu evitar o confisco de utensílios profissionais e objetos de uso lícito em geral $^{208}$. A perda dos instrumentos do crime por efeito de sentença penal condenatória não se volta sobre qualquer objeto utilizado na prática delituosa, ao contrário, justifica-se apenas se seu fabrico, alienação, uso, porte ou detenção constitua, per si só, fato ilícito ${ }^{209}$.

Contudo, para viabilizar o confisco é imprescindível haver elementos indiciários mínimos a demonstrar o nexo entre o material, bem ou valor adquirido e o provento direto ou indireto oriundo da prática criminosa ${ }^{210}$.

Durante a ação penal ou mesmo na fase de inquérito policial, esses bens móveis ou imóveis objeto de futuro e eventual confisco (como efeito automático de sentença penal condenatória) podem sofrer risco de dano durante o tempo em que perdurar o processo. Portanto, a fim de se evitar a ineficácia e inutilidade do processo, são previstas medidas cautelares patrimoniais apropriadas a esse fim.

Por derradeiro, para Gustavo HenRIQUe Righi IvAHY BADARÓ, nos processos que têm por objeto a lavagem de dinheiro ${ }^{211}$, medidas cautelares reais que neles venham a ser decretadas apresentam natureza muito peculiar, principalmente quando asseguram eficácia ao efeito automático da sentença penal condenatória quanto à perda do produto ou provento do crime ${ }^{212}$.

Conforme bem apontado por BADARÓ, a Lei 9.613/98, quando tratou sobre lavagem de capitais, em seu art. $4^{\circ}$, previu a possibilidade de ser objeto de medida cautelar

\footnotetext{
${ }^{207}$ NORONHA, Edgard Magalhães. Direito penal, cit., p. 325.

${ }^{208 ،} \mathrm{Na}$ verdade, confiscam-se aqueles instrumentos que, por sua destinação específica, são usados na prática de crimes, ou cujo uso ou porte sejam proibidos. Com essa previsão, nosso legislador visou evitar o confisco de utensílios profissionais, de trabalho, de estudo, enfim, objetos de uso lícito. Assim, o bisturi do médico, o automóvel que atropela a vítima, a navalha do barbeiro, embora instrumenta sceleris, não podem ser confiscados" (BITENCOURT, Cezar Roberto. Tratado de direito penal: parte geral, cit., p. 770).

${ }^{209}$ Por isso, v.g., descabe confisco de arma de fogo utilizada para a consecução do delito se seu porte, por parte do agente, era legalmente autorizado. Cf. REALE JÚNIOR, Miguel. Instituições de direito penal: parte geral, cit., p. 475. "Nem sempre o confisco é obrigatório; sê-lo-á quando os instrumenta forem proibidos ou importarem perigo" (NORONHA, Edgard Magalhães. Direito penal, cit.,, p. 324). No mesmo sentido: DELMANTO, Celso et al. Código Penal comentado. 6. ed. atual. e ampl. Rio de Janeiro: Renovar, 2002. p. 171.

${ }^{210}$ REALE JÚNIOR, Miguel. Instituições de direito penal: parte geral, cit., p. 476.

${ }^{211} \mathrm{O}$ crime de lavagem de dinheiro está previsto na Lei n. 9.613/1998, com recentes alterações introduzidas pela Lei n. 12.683/2012.

${ }^{212}$ BADARÓ, Gustavo Henrique Righi Ivahy; BOTTINI, Pierpaolo Cruz. Lavagem de dinheiro: aspectos penais e processuais penais. São Paulo: Ed. Revista dos Tribunais, 2012. p. 281-284.
} 
patrimonial o "instrumento, produto ou proveito dos crimes previstos nesta Lei ou das infrações penais antecedentes".

O legislador fez uma clara separação entre o produto e o provento relativos ao crime antecedente e o produto e o provento da própria lavagem de dinheiro. Essa importante diferenciação deve ser observada antes de se impor qualquer medida cautelar patrimonial no processo que tem por objeto a lavagem de dinheiro.

Imagine-se, a título de exemplo, lavagem de dinheiro cujo crime antecedente seja roubo (art. 157, do Código Penal) a uma instituição bancária ${ }^{213}$. A res furtiva (dinheiro roubado) é o produto do crime antecedente. Se, a partir desse dinheiro, o agente adquire imóveis, estes serão o resultado indireto do roubo, o provento do crime antecedente.

O produto e o provento do crime antecedente ainda podem se tornar objetos do crime de lavagem de dinheiro, a partir das chamadas "operações de branqueamento". O ganho aparentemente lícito dessas operações, uma vez já reintroduzido na economia formal depois de passar pelo branqueamento, será o produto da lavagem. E finda a atividade de reciclagem, se o agente utiliza o produto da lavagem para adquirir obras de arte, por exemplo, estas consistirão os proventos da lavagem ${ }^{214}$.

Desse modo, no processo que tem por objeto a lavagem de dinheiro, a medida cautelar patrimonial deve se referir tanto ao produto ou provento da infração penal antecedente, quanto ao produto da própria lavagem ${ }^{215}$.

\subsubsection{Características das medidas cautelaras patrimoniais no processo penal}

A doutrina reúne várias características fundamentais das medidas cautelares patrimoniais penais. Para escopo da presente dissertação, focaremos as características que entendemos indispensáveis à sua caracterização: instrumentalidade, provisoriedade, acessoriedade e referibilidade ${ }^{216}$.

\footnotetext{
${ }^{213}$ Registre-se que, de acordo com as alterações introduzidas pela Lei n. 12.683/2012 à Lei n. 9.613/1998, não mais existe um rol taxativo de crimes antecedentes à lavagem de dinheiro como antes se estabelecia.

${ }^{214}$ BADARÓ, Gustavo Henrique Righi Ivahy; BOTTINI, Pierpaolo Cruz. Lavagem de dinheiro: aspectos penais e processuais penais, cit., p. 282.

${ }^{215}$ BADARÓ, Gustavo Henrique Righi Ivahy; BOTTINI, Pierpaolo Cruz. Lavagem de dinheiro: aspectos penais e processuais penais, cit., p. 283.

${ }^{216}$ Além das que serão tratadas na presente dissertação, a doutrina costuma tratar de outras características da tutela cautelar, como a revogabilidade, a reversibilidade, a excepcionalidade e a jurisdicionalidade.
} 
Foi exposto que as medidas cautelares são instrumentos ou meios orientados a assegurar utilidade prática da tutela jurisdicional definitiva, por isso estão umbilicalmente associadas a uma futura e eventual sentença penal condenatória transitada em julgado ${ }^{217}$, cuja execução asseguram em caráter preventivo ${ }^{218}$.

As medidas cautelares penais guardam sempre uma relação necessária com o processo principal, o processo ao qual servem como "instrumento de segurança e de eficaz atuação" ${ }^{219}$, assegurando-lhe resultado útil e eficaz. Nascem, por assim dizer, a serviço de um provimento definitivo ${ }^{220}$.

Essa necessária relação das medidas cautelares penais com o provimento final em razão do qual são emanadas - faz com que as medidas cautelares nunca existam como um fim em si mesmas. Por isso, dizia CALAMANDREI, as medidas cautelares apresentam caráter eminentemente instrumental e qualificado: são hipotéticas ${ }^{221}$ e elevadas à segunda potência; são o "instrumento do instrumento" ${ }^{222}$, pois se destinam a assegurar outro meio de tutela - o processo $^{223}$.

Consequentemente, o caráter instrumental da tutela cautelar revela também sua relação mediata com o direito substancial. Ensinava BEDAQUE que, onde houvesse tutela cautelar, haveria sempre outra tutela ${ }^{224}$. A tutela cautelar opera a dar utilidade prática às tutelas cognitivas e executivas, estas, sim, com relação imediata com o direito material ${ }^{225}$.

Assim, segundo os ensinamentos de HUMBERTO THEODORO JÚNIOR, a eficácia da tutela cautelar sobre o direito substancial é mediata apenas, na medida em que se realiza

217 GONÇALVES, Marianna Moura. Prisão e outras medidas cautelares pessoais à luz da proporcionalidade, cit., p. 159.

${ }^{218}$ GIMENES, Marta Cristina Cury Saad. As medidas assecuratórias do Código de Processo Penal como forma de tutela cautelar destinada à reparação do dano causado pelo delito, cit., p. 69.

${ }^{219}$ THEODORO JÚNIOR, Humberto. Processo cautelar, cit., p. 62.

220، Queste considerazioni permettono di cogliere quella che, secondo me, è la nota veramente tipica dei provvedimenti cautelari: i quali non sono mai fine a sè stessi, ma sono immancabilmente preordinati alla emanazione di un ulteriore provvedimento definitivo, do cui essi preventivamente assicurano la fruttuosità pratica. Essi nascono, per cos`i dire, al servizio di un provvedimento definitivo..." (CALAMANDREI, Piero. Introduzione allo studio sistematico dei provvedimenti cautelari, cit., p. 21).

${ }^{221}$ Porque "sua concessão encontra-se na dependência de ser provável, em face daquele que a postula, a entrega da tutela jurisdicional definitiva ou principal” - tradução livre (CALAMANDREI, Piero. Introduzione allo studio sistematico dei provvedimenti cautelari, cit., p. 197-198).

${ }^{222}$ CALAMANDREI, Piero. Introduzione allo studio sistematico dei provvedimenti cautelari, cit., p. 21.

${ }^{223}$ GIMENES, Marta Cristina Cury Saad. As medidas assecuratórias do Código de Processo Penal como forma de tutela cautelar destinada à reparação do dano causado pelo delito, cit., p. 69.

${ }^{224}$ BEDAQUE, José Roberto dos Santos. Tutela cautelar e tutela antecipada: tutelas sumárias e de sistematização, cit., p. 144-145.

${ }^{225}$ GONÇALVES, Marianna Moura. Prisão e outras medidas cautelares pessoais à luz da proporcionalidade, cit., p. 159. 
por meio do processo principal, o qual se vale das medidas cautelares como instrumentos preciosos de segurança e eficácia para sua atuação útil e justa ${ }^{226}$.

Isto posto, a tutela cautelar não tem o condão de promover a solução imediata do litígio criado no âmbito do direito material. A tutela cautelar recai apenas sobre o processo, garantindo-lhe um resultado eficaz e útil - e não sobre o direito material. Esse traço é o que diferencia a tutela cautelar da tutela antecipatória.

Ao lado da instrumentalidade e a esta diretamente ligada, cumpre mencionar a característica provisória da tutela cautelar. Em razão da clara dependência que guardam com o provimento final, as medidas cautelares, ou bem se extinguem quando advier decisão final absolutória ou extintiva de punibilidade, ou bem se tornam definitivas em caso de sentença penal condenatória transitada em julgado, neste último caso podendo ser executadas na esfera cível ${ }^{227}$.

Em razão dessa provisoriedade, as medidas cautelares "são destinadas a ser absorvidas ou substituídas pela solução definitiva do mérito" ${ }^{228}$. Isto porque, "provisoriamente não se declaram direitos materiais nem obrigações, não se criam, nem se modificam ou extinguem relações jurídicas; provisoriamente, apenas se conservam ou alteram situações fáticas" 229 .

Ao ser proferida sentença no processo principal, a tutela cautelar exaure-se em sua função, operando a extinção ipso iure de seus efeitos $e x$ se, sem a necessidade de uma nova decisão que a revogue ${ }^{230}$.

Portanto, pode-se afirmar que a tutela cautelar penal nasce fadada a extinguirse, pois surge com a previsão de seu fim ${ }^{231}$ : deve perdurar até que sobrevenha provimento

\footnotetext{
${ }^{226}$ THEODORO JÚNIOR, Humberto. Processo cautelar, cit., p. 62.

${ }^{227}$ GIMENES, Marta Cristina Cury Saad. As medidas assecuratórias do Código de Processo Penal como forma de tutela cautelar destinada à reparação do dano causado pelo delito, cit., p. 69 .

${ }^{228}$ THEODORO JÚNIOR, Humberto. Processo cautelar, cit., p. 67. MARIANNA MOURA GONÇALVES critica a afirmação de que as medidas cautelares são provisórias, porque são fadadas a serem substituídas por outra tutela jurisdicional. Segundo a autora, tal afirmação, embora muito comum na doutrina, faz certa confusão entre tutela cautelar e tutela antecipatória. Por isso, prefere afirmar que a tutela cautelar nasce fadada a não ser definitiva e durar determinado intervalo de tempo (Prisão e outras medidas cautelares pessoais à luz da proporcionalidade, cit., p. 163-165).

${ }^{229}$ MACHADO, Antônio Cláudio da Costa. Considerações sobre a função cautelar: tertium genus, "direito substancial de cautela" e preventividade cautelar. Revista EPD, São Paulo, v. 2, n. 3, p. 17, out./nov. 2006.

${ }^{230}$ CALAMANDREI, Piero. Introduzione allo studio sistematico dei provvedimenti cautelari, cit., p. 82-86.

${ }^{231}$ THEODORO JÚNIOR, Humberto. Processo cautelar, cit., p. 66.
} 
jurisdicional definitivo no processo principal $^{232}$ e enquanto estiver presente a situação de perigo (à eficácia do processo) que lhe deu ensejo.

Além disso, a provisoriedade da tutela cautelar significa que poderá ser extinta, majorada ou substituída se restar modificada a situação de fato e de direito que justificou sua decretação ${ }^{233}$. Segundo CALAMANDREI, é possível considerar que a tutela cautelar é emanada com cláusula rebus sic stantibus, visto não ser estaticamente fixada para sempre, mas constituída a se projetar de acordo com novas situações jurídicas. A tutela cautelar destina-se "a viver e, portanto, a transformar-se se a dinâmica da vida o exige"234.

As medidas cautelares apresentam-se, ainda, como acessórias a um processo de cognição ou execução aos quais sempre se conectam - afinal, como se viu, têm o escopo de assegurar um resultado útil e eficaz ao processo de conhecimento e de execução, afastando o risco de dano decorrente da demora da prestação jurisdicional ${ }^{235}$. A acessoriedade da tutela cautelar também está presente no processo civil, no qual se reconhece a existência de um processo cautelar autônomo ${ }^{236}$, embora seja mais evidente no processo penal.

\footnotetext{
${ }^{232}$ CALAMANDREI fazia a distinção entre "temporariedade" (aquilo que dura determinado tempo) e "provisoriedade" (destinado a durar até que sobrevenha evento sucessivo). Para o mestre italiano, provisoriedade seria temporariedade condicionada à verificação de situação futura. Assim, CALAMANDREI preferia usar o termo provisoriedade a temporariedade para caracterizar as medidas cautelares, porque, mais que temporárias, são provisórias na medida em que não são unicamente fadadas a durar determinado lapso temporal; nascem para perdurar enquanto não se obtenha provimento final. (Introduzione allo studio sistematico dei provvedimenti cautelari, cit., p. 10-12). No mesmo sentido, GIMENES, Marta Cristina Cury Saad. As medidas assecuratórias do Código de Processo Penal como forma de tutela cautelar destinada à reparação do dano causado pelo delito, cit., p. 69-70.

${ }^{233}$ ASTILLEJO MANZANARES, Raquel. El nuevo tratamiento de las medidas cautelares en el proceso penal. Revista de Derecho y Proceso Penal, Navarra, v. 2, n. 26, p.13-23, 2011. De fato, muitos autores associam a provisoriedade à revogabilidade das medidas cautelares penais, na medida em que o caráter provisório da tutela cautelar não pode ser dissociado da possibilidade de ser revogado a qualquer momento, caso cessem as circunstâncias que a ensejaram. Neste mesmo sentido: GONÇALVES, Marianna Moura. Prisão e outras medidas cautelares pessoais à luz da proporcionalidade, cit., p. 168.

234 "Anche i provvedimenti cautelari si possono considerare come emanati con la clausola 'rebus sic stantibus', posto che essi non contengono l'accertamento di un rapporto esaurito nel passato e destinato per questo, a rimanere attraverso il passaggio in giudicato, staticamente fissato per sempre; ma costituiscono per proiettarlo nell'avvenire un rapporto giuridico nuovo (rapporto cautelare), destinato a vivere e quindi a trasformarsi se la dinamica della vita lo esige". Portanto, conclui o jurista italiano: "la stessa autorità che ha emanato il provvedimento potrà attraverso una nuova cognizione sommaria modificarlo o provocarlo, se in pendenza del giudizio principale si siano verificate nuove circostanze che sconsiglino la continuazione del rapporto cautelare originalmente costituito" (CALAMANDREI, Piero. Introduzione allo studio sistematico dei provvedimenti cautelari, cit., p. 80).

${ }^{235}$ GONÇALVES, Marianna Moura. Prisão e outras medidas cautelares pessoais à luz da proporcionalidade, cit., p. 168-169.

${ }^{236}$ Embora autônomo por seu objeto, o processo cautelar no processo civil também não justifica sua existência por si mesma, "mas pela relação necessária que guarda com outro processo principal" (THEODORO JÚNIOR, Humberto. Processo cautelar, cit., p. 61).
} 
Uma última característica das medidas cautelares diz respeito à referibilidade. A tutela cautelar penal destina-se a garantir utilidade e eficácia de um pronunciamento condenatório definitivo, diante de determinado fato de direito material. A referibilidade no processo penal opera, portanto, na observação de Gustavo HenRIQUE Righi Ivahy BADARÓ, na medida em que "a cautelar se refere à punição por um crime específico, visando a assegurar a utilidade e eficácia do provimento final condenatório que tenha por objeto tal delito" 237 .

Nas medidas cautelares patrimoniais, por efeito da referibilidade, a constrição dos bens do investigado, acusado ou condenado não poderá ser mais gravosa do que o valor do dano a ser satisfeito em caso de futura e eventual condenação ${ }^{238}$. A referibilidade, como se pode verificar, revela-se como instrumento de aferição dos limites da medida constritiva patrimonial, a denotar sua importância ${ }^{239}$.

\subsubsection{Pressupostos das medidas cautelares patrimoniais no processo penal}

\subsubsection{Fumus comissi delicti}

No processo civil, fala-se genericamente em fumus boni iuris - "fumaça do bom direito" - como um dos pressupostos da tutela cautelar, ao lado do periculum in mora.

Suscintamente, o fumus boni iuris consiste em um juízo de probabilidade e de verossimilhança, através do qual o julgador vislumbra a previsibilidade de que o provimento final será favorável à parte beneficiada pela medida cautelar solicitada ${ }^{240}$.

Para se chegar à análise da probabilidade da existência do direito reclamado e da verossimilhança das alegações apresentadas, deve-se constatar se há nexo entre a tutela cautelar e o direito material ${ }^{241}$. Assim, não se pode dissociar o fumus boni iuris do plano material. Essa análise, contudo, dá-se por uma cognição sumária e não

\footnotetext{
${ }^{237}$ BADARÓ, Gustavo Henrique Righi Ivahy. Medidas cautelares patrimoniais no processo penal, cit., p. 170-171.

${ }^{238}$ BADARÓ, Gustavo Henrique Righi Ivahy. Medidas cautelares patrimoniais no processo penal, cit., p. 171.

${ }^{239}$ GONÇALVES, Marianna Moura. Prisão e outras medidas cautelares pessoais à luz da proporcionalidade, cit., p. 169-170.

${ }^{240}$ GIMENES, Marta Cristina Cury Saad. As medidas assecuratórias do Código de Processo Penal como forma de tutela cautelar destinada à reparação do dano causado pelo delito, cit., p. 207-208.

${ }^{241}$ BEDAQUE, José Roberto dos Santos. Tutela cautelar e tutela antecipada: tutelas sumárias e de sistematização, cit., p. 190.
} 
exauriente - daí ser um juízo de mera probabilidade; o juízo de certeza levaria à tutela definitiva e não à tutela cautelar ${ }^{242}$.

No processo penal, a doutrina tem preferido utilizar a expressão fumus comissi delicti, ou seja, a probabilidade da ocorrência de um fato tipificado como crime e nunca de um direito ${ }^{243}$. Bem assevera MARTA CRISTINA CURY SAAD GIMENES: "a circunstância de as cautelares patrimoniais penais se dirigirem a assegurar a satisfação de créditos ou interesses derivados do delito leva a supor que a chamada 'aparência do direito' deveria se identificar, ao menos legalmente, com a existência de prova da existência do delito" ${ }^{\text {244. }}$.

Com efeito, a ideia de fumus boni iuris remete ao juízo prognóstico da plausibilidade jurídica do direito tido por violado e da verossimilhança dos fatos alegados. Haveria um dano irreparável ao direito que o autor deseja ver reconhecido.

Ora, primeiro, é bem discutível a existência de lide no processo penal ${ }^{245}$. Segundo, o processo penal visa a punir o autor pela prática de um delito. Se o crime é a negação do próprio direito, sendo, portanto, sua antítese, no mínimo é contraditório afirmar que o delito seja a "fumaça do bom direito",246. Terceiro e último lugar, permitir que o juiz criminal faça o juízo preliminar e o prognóstico da probabilidade de eventual resultado favorável à acusação - por vezes, até antes mesmo da instauração da ação penal - vai na

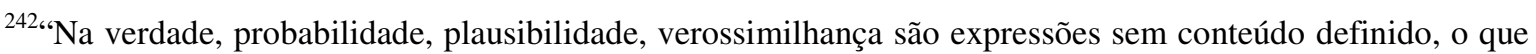
possibilita ao juiz, em cada caso concreto, maior liberdade para identificar a presença do requisito necessário à concessão da cautelar. Mas não parece possível afastá-lo do plano material, pois de outra cognição não se trata senão de um direito aparentemente existente, conclusão a que se chega mediante cognição sumária. Fumus boni iuris significa, portanto, juízo de verossimilhança, decorrente de cognição superficial, não exauriente, da relação material. A cognição plena leva ao juízo de certeza, autorizando a tutela definitiva" (BEDAQUE, José Roberto dos Santos. Tutela cautelar e tutela antecipada: tutelas sumárias e de sistematização, cit., p. 192-193). Em sentido contrário: "o requisito da ação cautelar, anteriormente apontado como o fumus boni iuris deve, na verdade, corresponder não propriamente à existência do direito material - pois qualquer exame a respeito só é próprio da ação principal -, mas sim à verificação efetiva de que, realmente, a parte dispõe do direito de ação, direito ao processo principal a ser tutelado" (THEODORO JÚNIOR, Humberto. Processo cautelar, cit., p. 76).

243،...o significado da 'fumaça do bom direito', no processo civil, não tem correspondência no processo penal, porque o delito não é uma 'fumaça do bom direito'. Os autores modernos têm preferido utilizar a expressão fumus delicti, ou seja, 'a probabilidade da ocorrência de um delito e nunca de um direito', como um dos pressupostos para a decretação de medida cautelar de caráter pessoal, significando prova da existência material do crime e indícios suficientes de autoria” (MOURA, Maria Thereza Rocha de Assis. Justa causa para a ação penal: doutrina e jurisprudência. São Paulo: Ed. Revista dos Tribunais, 2001. p. 208).

${ }^{244}$ GIMENES, Marta Cristina Cury Saad. As medidas assecuratórias do Código de Processo Penal como forma de tutela cautelar destinada à reparação do dano causado pelo delito, cit., p. 44.

${ }^{245}$ Defendem não existir lide no processo penal: BADARÓ, Gustavo Henrique Righi Ivahy. Ônus da prova no processo penal. São Paulo: Ed. Revista dos Tribunais, 2003; LOPES JR., Aury. Direito processual penal e sua conformidade constitucional. 6. ed. Rio de Janeiro: Lumen Juris, 2010. v. 1, p. 328.

${ }^{246}$ LOPES JR., Aury. Introdução crítica ao processo penal: fundamentos da instrumentalidade constitucional, cit., p. 200.
} 
contramão dos direitos fundamentais assegurados na Constituição Federal, principalmente a não presunção de culpabilidade ${ }^{247}$.

A aplicação cega e literal de doutrina processual civil ao processo penal sem o devido temperamento pode causar sérias distorções conceituais ${ }^{248}$. Por isso, no campo penal, seria mais adequado designar como pressuposto à decretação de medidas cautelares patrimoniais não a existência da probabilidade do direito da acusação ("fumaça do bom direito da acusação"), mas a presença de fumus comissi delicti.

Desse modo, constitui pressuposto à decretação de uma medida cautelar penal a probabilidade de ocorrência de um delito - e não de um direito ${ }^{249}$.

\subsubsection{Periculum in mora}

A tutela cautelar também pressupõe a existência do periculum in mora ${ }^{250}$, o risco provável de dano que poderá advir do retardo do processo principal ${ }^{251}$.

\footnotetext{
${ }^{247}$ Em semelhante sentido, sustenta MARTA CRISTINA CURY SAAD GIMENES: "Esta formulação do fumus, como pressuposto das medidas cautelares - aparência de quem se verá favorecido pela tutela cautelar, isto é, como exigência de que para sua adoção se proceda a juízo por meio do qual o órgão jurisdicional possa prever que a resolução final resultará favorável àquele que solicita a medida cautelar -, se é válida no processo civil, não pode ser transportada pura e simplesmemte para o processo penal. Seria absurdo entender-se que o juízo que se procede, no processo penal, para a decretacão da medida cautelar, seria um juízo do provável sucesso do direito afirmado pelo acusador. Primeiro, porque só ao fim da ação penal de conhecimento, de natureza condenatória, é que se pode avaliar se a acusação é ou não procedente. Depois, porque o juízo que se vai formando, ao longo do processo, é diverso do juízo da causa, definitivo, que não se antecipa, nem se tem como provável. Assim, no processo penal, que possui pressupostos, netureza e fims diveros, não há como se admitir o fumus boni iuris como pressupsoto para a decretação das medidas cautalares patrimoniais, não ao menos nos termos propostos no âmbito do processo civil" (As medidas assecuratórias do Código de Processo Penal como forma de tutela cautelar destinada à reparação do dano causado pelo delito, cit., p. 42-43).

${ }^{248}$ AURY LOPES JR. trata especificamente desse tema quando critica a prática de alguns autores de transportar alguns conceitos de CALAMANDREI "de forma imediata e impensada": "O equívoco consiste em buscar a aplicação literal da doutrina processual civil ao processo penal, exatamente em um ponto em que devemos respeitar as categorias próprias do processo penal, pois não é possível tal analogia" (Introdução crítica ao processo penal: fundamentos da instrumentalidade constitucional, cit., p. 200).

${ }^{249}$ LOPES JR., Aury. Introdução crítica ao processo penal: fundamentos da instrumentalidade constitucional, cit., p. 200. Em sentido contrário: "Outro resultado para a imposição da medida cautelar é o chamado fumus boni iuris, ou fumaça do bom direito, ou seja, a probabilidade de resultado favorável do processo principal, para aquele a quem a medida acautelatória irá beneficiar" (ARRUDA, Eloisa de Sousa. As medidas cautelares reais no processo penal brasileiro, cit., p. 52).

${ }^{250}$ Segundo JOSÉ ROBERTO BADAQUE, "o periculum in mora é a característica essencial e distintiva do provimento cautelar. Sem periculum in mora não há por que recorrer à tutela cautelar, pois ele representa a própria razão de existência dessa modalidade especial de proteção jurisdicional" (Tutela cautelar e tutela antecipada: tutelas sumárias e de sistematização, cit., p. 159).

${ }^{251}$ CALAMANDREI, Piero. Introduzione allo studio sistematico dei provvedimenti cautelari, cit., p. 18.
} 
O dispêndio de tempo demandado para o regular desenvolvimento processual pode prolongar demasiadamente a satisfação do direito discutido em juízo, o que a doutrina italiana identificou como pericolo da tardività ${ }^{252}$.

Durante o desenvolvimento da atividade jurisdicional, gera-se risco potencial de prejuízo à efetividade do provimento final e, consequentemente, do direito deduzido em juízo ${ }^{253}$. Assim, segundo José RoBERTo BEDAQUE, existe um dano inerente à demora do processo; um dano marginal, ínsito, natural, “decorrente apenas do tempo necessário a que a prestação jurisdicional possa ser fornecida, respeitadas todas as garantias do devido processo legal" ${ }^{\prime 254}$.

D`outro vértice, durante este lapso de tempo, é possível ocorrer fatos ou ações que impossibilitem ou dificultem a efetividade prática da decisão final, como, v. g., o desaparecimento ou a diminuição dos bens do acusado ${ }^{255}$. É o que a doutrina italiana chama de pericolo da infruttuosità, consistente no risco de ineficácia do provimento jurisdicional em razão de acontecimentos ou mudanças no estado das coisas durante a realização do devido processo legal ${ }^{256}$.

\footnotetext{
${ }^{252}$ Para CALAMANDREI, “e specificamente il pericolo di quell'ulteriore danno marginale, che potrebbe derivare dal ritardo, reso inevitabile dalla lentezza del procedimento ordinario, del provvedimento definitivo. `E la impossibilità pratica di accelerare la emanazione del provvedimento definitivo, che fa sorgere l'interesse alla emanazione di una misura provvisoria" (Introduzione allo studio sistematico dei provvedimenti cautelari, cit., p. 18).

${ }^{253}$ "A tutela cautelar pressupõe a existência de perigo para a efetividade do provimento definitivo e, consequentemente, para o direito deduzido em juízo." (BEDAQUE, José Roberto dos Santos. Tutela cautelar e tutela antecipada: tutelas sumárias e de sistematização, cit., p. 159).

254 "Outro, todavia, é o perigo causado pela mera duração excessiva do processo de cognição plena, circunstância que também pode gerar prejuízo ao titular do direito. Mas aqui não se vislumbra a necessidade de a medida de urgência preservar para garantir eficácia. A ameaça à efetividade do provimento da tutela satisfativa, por si só, constitui causa do dano, pois reduz ou até elimina a utilidade que o provimento satisfativo representa para a esfera jurídica do titular de direito. Trata-se de perigo causado pela demora, pelo atraso na entrega da prestação, cuja eliminação depende de medidas urgentes, voltadas para a própria satisfação do direito, antecipada e provisoriamente". Trata-se do "pericolo de tardività" (BEDAQUE, José Roberto dos Santos. Tutela cautelar e tutela antecipada: tutelas sumárias e de sistematização, cit., p. 175-271). Para CALAMANDREI, o reconhecimento do periculum in mora tem a função de "neutralizzare il danno che potrebbe derivare dal ritardo del provvedimento principale". Portanto, "il problema che il giudice deve proporsi in sede cautelare, per riconoscere esistente il periculum in mora che lo autorizza a provvedere interinalmente, non è di vedere se il diritto del richiedente sia in pericolo, ma di vedere se questo pericolo sarebbe suscettibile di aggravarsi e magari di trasformarsi in danno irrimediabile, ove, per determinare le misure migliori atte a prevenirlo, si dovesse attendere fino alla emanazione dal provvedimento principale" (Introduzione allo studio sistematico dei provvedimenti cautelari, cit., p. 70).

${ }^{255}$ GIMENES, Marta Cristina Cury Saad. As medidas assecuratórias do Código de Processo Penal como forma de tutela cautelar destinada à reparação do dano causado pelo delito, cit., p. 47.

${ }^{256}$ GONÇALVES, Marianna Moura. Prisão e outras medidas cautelares pessoais à luz da proporcionalidade, cit., p. 180.
} 
O conteúdo jurídico do periculum in mora, pode-se assim dizer, desdobra-se nos conceitos destes dois elementos: pericolo da tardività e pericolo da infruttuosità.

A identificação do periculum in mora pode ser deixada a cargo do Juiz, quando o legislador não fixa limites precisos do perigo. Neste caso, caberá ao magistrado julgar a conveniência da medida de acordo com as circunstâncias do caso concreto.

Diversamente, pode o legislador antever modalidades de tutela específicas, nas quais já se encontre previamente determinado o periculum in mora. Assim, são previstas situações de risco em razão das quais a cautelar é admissível. Pode, ainda, o legislador deixar de exigir a demonstração do perigo, "contentando-se com a cognição sumária a respeito da existência do direito afirmado, que revelará a presença do fumus boni iuris. Neste último caso, a valoração quanto ao perigo já é feita antecipadamente e em abstrato pelo legislador, 257 .

Fundamentalmente, existem duas correntes doutrinárias quanto aos critérios de aferição do periculum.

Para uma primeira corrente, o periculum configura-se apenas em decorrência do dano marginal, ou seja, da possibilidade de perigo advinda do tempo que naturalmente se espera à conclusão do processo. Assim, há situações nas quais, para a concessão de medida cautelar, o legislador considera suficiente o mero transcurso do tempo necessário ao provimento final como agente capaz de produzir fatos ou ações que impossibilitem ou dificultem a efetiva satisfação do direito. Neste caso, a verificação do fumus boni iuris bastaria à análise do magistrado, porque o periculum in mora não se mostraria efetivo pressuposto fundamental à tutela cautelar ${ }^{258}$.

Contrariamente, uma segunda corrente defende a necessidade de estar à disposição do magistrado dados efetivos e concretos a demonstrar a possibilidade de que o

\footnotetext{
${ }^{257}$ BEDAQUE, José Roberto dos Santos. Tutela cautelar e tutela antecipada: tutelas sumárias e de sistematização, cit., p. 179. No mesmo sentido: "o periculum configura um verdadeiro pressuposto para a decretação de medidas cautelares patrimoniais. Ocorre que, algumas vezes, o legislador objetiva ou tipifica as condutas que evidenciam o perigo e, em outras, ao contrário, permite que o juiz determine o grau de perigo existente, em atenção às circunstâncias alegadas pela parte que solicita a medida. Esta peculiaridade, todavia, não permite concluir que no primeiro caso o pressuposto seja autêntico e no segundo não o seja. $\mathrm{O}$ perigo é formado de dois componentes: perigo de retardamento e perigo de infrutuosidade. Centrar-se apenas no último seria discriminar a atenção que se deve dar à margem de apreciação concedida pelo juiz, o que conduziria a negar validade ao periculum para praticamente a totalidade das medidas cautelares" (GIMENES, Marta Cristina Cury Saad. As medidas assecuratórias do Código de Processo Penal como forma de tutela cautelar destinada à reparação do dano causado pelo delito, cit., p. 47).

${ }^{258}$ GIMENES, Marta Cristina Cury Saad. As medidas assecuratórias do Código de Processo Penal como forma de tutela cautelar destinada à reparação do dano causado pelo delito, cit., p. 48.
} 
dano temido venha a se concretizar, caso não se intervenha com urgência - o dano concreto $^{259}$. Neste caso, a lei prevê e exige determinado comportamento do acusado como sinal do perigo de infrutuosidade, não bastando o mero transcurso do tempo. Para este segundo critério, o periculum se revelaria autêntico pressuposto, cuja ocorrência deve ser verificada in concreto para a concessão da medida cautelar.

No sistema brasileiro de processo penal, admite-se simples dano marginal às medidas cautelares reais, ao passo que se exige de maneira geral dano concreto às medidas cautelares reais no âmbito do processo civil. Tal contradição, muito criticada pela doutrina, será melhor analisada no item 2.4.1.

\subsection{Medidas cautelares patrimoniais penais no direito brasileiro e comparado}

No contexto da cooperação jurídica internacional em matéria penal, é bem certo que a execução automática de pedido de assistência, sem o devido temperamento à ordem pública interna, pode levar ao cumprimento de medidas cautelares patrimoniais em desacordo com garantias fundamentais da pessoa atingida (segundo o ordenamento jurídico do Estado requerido, que é o país onde estão localizados os bens a serem objeto de constrição e para o qual se destina o pedido de cooperação).

Não significa dizer que a correspondência exata entre os modelos processuais seja condição insuperável ao atendimento do pedido da assistência jurídica internacional. Como vértice oposto de uma mesma moeda, contudo, a desconfiança frente a diferente opção de medida cautelar patrimonial pode dar gênese à recusa sistemática, por um país, ao cumprimento de medida solicitada por um outro país, inviabilizando a eficiência do fluxo cooperacional.

A fim de identificar os possíveis pontos de conflito que decorrem, sobretudo, das diferentes opções de direito processual penal, mostra-se necessário estudar o regime das medidas cautelares patrimoniais penais no sistema jurídico brasileiro em confronto com a legislação italiana e portuguesa, pois Itália e Portugal estão entre os países dos quais o Brasil mais demanda em matéria de cooperação jurídica, sendo, também, os Estados remetentes de maior parte dos pedidos de cooperação internacional que chegam ao Brasil ${ }^{260}$.

\footnotetext{
${ }^{259}$ GIMENES, Marta Cristina Cury Saad. As medidas assecuratórias do Código de Processo Penal como forma de tutela cautelar destinada à reparação do dano causado pelo delito, cit., p. 48.

${ }^{260}$ Segundo as estatísticas divulgadas pelo Ministério da Justiça, Portugal e Itália, ao lado de EUA, Japão e Argentina foram os países com os quais o Brasil mais se relacionou no âmbito da cooperação jurídica internacional em matéria penal nos anos de 2011 e 2012. Fonte: MINISTÉRIO DA JUSTIÇA. Disponível em: <http://portal.mj.gov.br>. Acesso em: 24 ago. 2013.
} 
A eleição dos sistemas italiano e português como objeto de estudo de direito comparado justifica-se também pelo fato de terem sido operadas, em tais países - assim como no Brasil, pela Lei n. 11.435, de 28 de dezembro de 2006 - importantes mudanças no campo das tutelas cautelares penais, com o objetivo de simplificar e clarear as hipóteses de aplicação das modalidades de medidas cautelares patrimoniais ${ }^{261}$.

Por fim, considerando o objetivo do presente capítulo, que é identificar os possíveis pontos de conflito entre diferentes modelos de medidas cautelares patrimoniais no âmbito da cooperação jurídica internacional em matéria penal, trataremos apenas dos aspectos que identificamos como mais pertinentes do direito brasileiro e estrangeiro.

\subsubsection{Medidas cautelares patrimoniais penais no Brasil}

No direito brasileiro, é forçoso destacar o avanço dos trabalhos desenvolvidos sobre a tutela cautelar no processo civil, sobretudo na louvável tentativa, por parte de seus doutrinadores, de sistematizar a matéria. Os estudos da tutela cautelar no processo civil têm fornecido ferramentas valiosas ao desenvolvimento de uma sistematização da cautelar no processo penal no Brasil.

Contudo, elementos de profunda dissociação entre ambas as esferas não têm sido ignorados pela doutrina brasileira.

No entendimento de MARIANNA MOURA GONÇALVES, os princípios informadores do processo penal e o conflito travado entre o ius libertatis e o ius puniendi exigem atenção do intérprete, de maneira que o estudo da cautelaridade no processo penal deve buscar certa autonomia ${ }^{262}$. A análise da tutela cautelar na seara penal exige atenção às categorias intrínsecas ao processo penal e adequadas às particularidades do seu objeto ${ }^{263}$.

\footnotetext{
${ }^{261}$ Cf. GIMENES, Marta Cristina Cury Saad. As medidas assecuratórias do Código de Processo Penal como forma de tutela cautelar destinada à reparação do dano causado pelo delito, cit., p. 180.

262 GONÇALVES, Marianna Moura. Prisão e outras medidas cautelares pessoais à luz da proporcionalidade, cit., p. 143.

${ }^{263}$ Neste sentido: "Como identificou J. GOLDSCHMIDT, grave problema existe no paralelismo entre processo civil e processo penal, principalmente quando são buscadas categorias e definições do processo civil e pretende-se sua aplicação automática no processo penal. $\mathrm{O}$ fenômeno do processo civil é bastante claro e distinto daquele que caracteriza o processo penal. Assim, é necessário respeito às categorias jurídicas próprias do processo penal, adequadas às particularidades do seu objeto. Nisso reside a necessidade de revisar alguns conceitos erroneamente utilizados pelo senso comum teórico (e também jurisprudencial) em torno do requisito e fundamentos da prisão, bem como do seu objeto" (LOPES JR., Aury. Introdução crítica ao processo penal: fundamentos da instrumentalidade constitucional, cit., p. 199).
} 
Assim, qualquer estudo sobre a tutela cautelar civil deve sujeitar-se ao devido temperamento e ponderação ${ }^{264}$ antes de influir na seara processual penal.

Outra questão a ser analisada diz respeito à suposta autonomia do processo cautelar no direito processual penal brasileiro: discute-se se haveria um processo cautelar autônomo de natureza penal originado a partir do exercício de uma ação (penal) cautelar.

A despeito do posicionamento em sentido contrário ${ }^{265}$, entendemos que a tutela cautelar, no processo penal brasileiro, é exercida através de simples medidas incidentais e não propriamente por uma ação ou processo cautelar autônomo ${ }^{266}$.

\footnotetext{
${ }^{264}$ Frise-se, por oportuno, as críticas que se faz na doutrina brasileira aos estudos do processualista italiano Piero CALAMANDREI. Com efeito, são se ignora a solar importância dos estudos de Calamandrei ao desenvolvimento da cautelaridade no processo penal, afinal, como bem salientou GIUSEPPE TARZIA, "il maggior sviluppo della dottrina sulla tutela cautelare (...) si deve notoriamente a Calamandrei. Si può ben dire che la sistemazione di Calamandrei, salvo per alcuni (ma non trascurabili) aspetti, sia ancora oggi dominante." (Procedimenti cautelari. Padova: Casa Editrice Dott. Antonio Milano, 1990. p. 16). Por outro lado, conforme pondera AURY LOPES JR., "É necessário abandonar a doutrina civilista de Calamandrei para buscar conceitos próprios e que satisfaçam plenamente as necessidades do processo penal, recordando, sempre, que as medidas cautelares são instrumentos a serviço do processo, para tutela da prova ou para garantir a presença da parte passiva" (Introdução crítica ao processo penal: fundamentos da instrumentalidade constitucional, cit., p. 201). TUCCI e DELMANTO apontam como crítica a Calamandrei, $v$. g., no ponto em que o autor italiano defende que a "a antecipação provisória de determinados efeitos do ato decisório definitivo" seria o traço comum a todas as medidas cautelares (antecipação dos efeitos declaratórios, constitutivos e condenatórios do julgamento meritório). Esta definição aproximaria muito a tutela cautelar da tutela antecipada do processo civil. Assinalam os autores ser tal concepção não aplicável ao processo penal, pois, em matéria penal, é vedada qualquer antecipação dos efeitos da sentença que ainda será proferida em desfavor do acusado, em razão do princípio da presunção de inocência. "Se as medidas cautelares fossem antecipações de uma eventual condenação, todas elas - aí incluídas as prisões não decorrentes de sentença condenatória transitada em julgado, bem como o sequestro de bens para garantir a reparação do ilícito, um dos efeitos da condenação (Código Penal, art. 91, I) - seriam contra constitutionem: o provimento teria fundamentação incompatível com a Constituição da República" (TUCCI, Rogério Lauria; DELMANTO JÚNIOR, Roberto. Sistematização das medidas cautelares processuais penais, cit., p. 114).

265، 'Todavia, afigura-nos indiscutível a existência do processo cautelar, ao lado do de conhecimento e do executivo. O fim da atividade jurisdicional nas providências preventivas ou cautelares é diverso daquele que se verifica nas duas outras espécies de processo. E admitido, assim, o processo cautelar, inquestionável terá a existência das ações de igual nome" (MARQUES, José Frederico. Elementos de direito processual penal. Campinas: Bookseller, 2002. v. 1, p. 301). "Discute-se na doutrina, aliás, se o processo Penal brasileiro possui ou comporta ações cautelares propriamente ditas, devendo-se resolver positivamente essa questão (...) - até porque, para que se mantenha a possibilidade de prisão preventiva ou outra medida cautelar na fase de inquérito policial (enquanto não há ação e, portanto, não se pode falar em decisão incidental ou interlocutória), é imperativo considerar a existência de uma ação cautelar" (LEITE, Larissa. Medidas patrimoniais de urgência no processo penal: implicações teóricas e práticas, cit., p. 120).

${ }^{266}$ CARNELUTTI, Francesco. Principi del processo penale. Napoli: Morano, 1960. p. 182; TUCCI, Rogério Lauria; DELMANTO JÚNIOR, Roberto. Sistematização das medidas cautelares processuais penais, cit.; DELMANTO, Fábio Machado de Almeida. Medidas substitutivas e alternativas à prisão cautelar. 2006. Tese (Mestrado) - Faculdade de Direito da Universidade de São Paulo, 2006; GIMENES, Marta Cristina Cury Saad. As medidas assecuratórias do Código de Processo Penal como forma de tutela cautelar destinada à reparação do dano causado pelo delito, cit.; BADARÓ, Gustavo Henrique Righi Ivahy. Medidas cautelares patrimoniais no processo penal, cit.; "Na verdade, quando se diz que existe no processo penal um 'processo penal cautelar', quer se referir que existe uma tutela jurisdicional cautelar, mas com a particularidade de que não há propriamente ação ou processo cautelar autônomo, pois a tutela jurisdicional cautelar se excede através de medidas cautelares no bojo do processo principal, via de regra" (LIMA,
} 
Portanto, as medidas cautelares penais prescindem de petição inicial e são veiculadas por meros requerimentos. Ademais, não se exige correspondente sentença nem se identifica base procedimental própria.

Diferente do processo civil, que admite a existência de verdadeiras ações cautelares como terceiro gênero (ao lado da ação de conhecimento e de execução) ${ }^{267}$, a tutela cautelar no processo penal brasileiro se exercita por medidas incidentes ao processo de execução ou de conhecimento.

BEDAQUE, ao discorrer sobre as tutelas sumárias no processo civil, diz que, por vezes, é preciso antecipar a tutela final mediante cognição menos profunda do mérito, ao que chama de "tutela antecipatória". Noutras, é preciso dar maior dose de eficiência ao resultado do provimento final do processo, independente de qualquer produção de efeitos no plano material (tutela cautelar) ${ }^{268}$.

Entretanto, não se admite qualquer intento satisfativo e antecipatório à tutela cautelar no direito processual penal brasileiro.

A tutela cautelar de natureza penal não deve antecipar os efeitos do provimento jurisdicional, nem satisfazer antecipadamente a pretensão executória estatal ${ }^{269}$. Como

Marcellus Polastri. Algumas medidas preventivas, mas não cautelares, no processo penal. In: LIMA, Marcellus Polastri (Coord.). Estudos criminais em homenagem a Weber Martins Batistas. Rio de Janeiro: Lumen Juris, 2008. p. 225-226); GONÇALVES, Marianna Moura. Prisão e outras medidas cautelares pessoais à luz da proporcionalidade, cit.

${ }^{267}$ No processo civil, grande parte da doutrina convencionou pregar a autonomia do processo cautelar (GONÇALVES, Marianna Moura. Prisão e outras medidas cautelares pessoais à luz da proporcionalidade, cit., p. 156). No mesmo sentido, ensina HUMBERTO THEODORO JÚNIOR que, no processo civil, a tutela cautelar é exercida por meio de um processo contencioso. Entretanto, esse processo cautelar não se preocupa com a tutela do direito, a "função principal da jurisdição", pois "exerce função auxiliar e subsidiária, servindo à tutela do processo, onde será protegido o direito". Assim, se existe um processo cautelar, não há como negar a existência de uma ação cautelar, que se justifica através de um "direito subjetivo à tutela jurisdicional tutelar". Segundo o autor, as medidas cautelares "implicam atividade dos organismos do Estado encarregados de prestar a tutela jurídica, e o que fazem na presença de uma situação controvertida ou litigiosa". Por sua natureza jurisdicional, portanto, as medidas cautelares processuais civis assentam sua unidade e autonomia na trilogia "jurisdição-ação-processo". O único traço diferenciador do processo cautelar dos demais processos (cognição e execução) está no seu fim específico, que é a preservação. Tendo em vista que o processo cautelar não visa a assegurar o direito substancial, mas tãosomente o processo, "não se busca com a cautela a composição da lide (fim da atividade jurisdicional principal), mas tão-somente a eliminação de situações perigosas que possam afetar, eventualmente, a eficácia do futuro provimento principal ou de mérito" (Processo cautelar, cit., p. 43-63). Segundo ANTÔNIO CLÁUdIO DA COSTA MACHADO, existe autonomia funcional do processo cautelar em relação aos processos de conhecimento e execução, ou seja, "representa um terceiro serviço processual que não se confunde com os próprios dos processos de conhecimento e de execução, apesar de sua instrumentalidade em relação a um ou outro". Por isso, muitos doutrinadores o denominam de tertium genius (Considerações sobre a função cautelar: tertium genus, "direito substancial de cautela" e preventividade cautelar, cit., p. 18).

${ }^{268}$ BEDAQUE, José Roberto dos Santos. Tutela cautelar e tutela antecipada: tutelas sumárias e de sistematização, cit., p. 117-118.

${ }^{269}$ Em sentido contrário: ARRUDA, Eloisa de Sousa. As medidas cautelares reais no processo penal brasileiro, cit. 
observa RoGÉRIO LAURIA TUCCI, em função do princípio da não consideração prévia de culpabilidade, "a Constituição Federal jamais admitiria medidas cautelares penais que se prestassem, antecipadamente, ao reconhecimento de culpa ou à prática de qualquer ato de execução de pena" 270 .

Ademais, a tutela cautelar no processo penal está intimamente ligada à ideia de preservação, não para satisfazer situação da vida carecedora de tutela, mas, sim, para afastar o risco de se ver desprovida de completa utilidade e de eficácia a sentença a ser alcançada no processo principal $^{271}$.

A tutela cautelar no processo penal volta-se a assegurar os efeitos do processo em si, garantindo-lhe resultado útil e eficaz caso advenha provimento final condenatório. Portanto, não se presta a tutelar de maneira imediata o direito material sub judice ${ }^{272}$, como é próprio da cautela antecipatória no processo civil ${ }^{273}$.

No processo penal brasileiro, as medidas cautelares de natureza penal são sempre típicas. Somente podem ser decretadas as medidas que forem previstas no ordenamento, em virtude do princípio constitucional previsto no artigo $5^{\circ}$, LIV, da CF, no sentido de que "ninguém pode ser privado da liberdade ou de seus bens sem o devido processo legal" 274 . Consequentemente, não existe no processo penal brasileiro o poder

\footnotetext{
${ }^{270}$ TUCCI, Rogério Lauria; DELMANTO JÚNIOR, Roberto. Sistematização das medidas cautelares processuais penais, cit., p. 115.

${ }^{271}$ GONÇALVES, Marianna Moura. Prisão e outras medidas cautelares pessoais à luz da proporcionalidade, cit., p. 145.

${ }^{272}$ Segundo CALAMANDREI, a tutela cautelar, "più che lo scopo di attuare il diritto, lo scopo immediato di assicurare la efficacia pratica del provvedimento definitivo che servirà a sia volta ad attuare il diritto. La tutela cautelare `e, nei confronti del diritto sostanziale, una tutela mediata: più che a far giustizia serve a garantire l'efficace funzionamenti della giustizia". Por isso, afirma o autor, a urgência na tutela penal não é a satisfação do direito, mas assegurar que o processo principal seja justo e eficaz (Introduzione allo studio sistematico dei provvedimenti cautelari, cit., p. 21 e 56).

${ }^{273}$ A medida cautelar é sempre acessória e provisória e, às vezes, no processo civil, preparatória, mas não somente as cautelares têm essas características: as liminares em Mandado de Segurança, por exemplo, são medidas provisórias, mas não são cautelares por sua natureza satisfativa e de garantia do direito material. Disto decorre a diferenciação entre tutela cautelar (medidas provisórias de natureza cautelar) e tutela antecipatória (medidas provisórias de natureza antecipatória, esta de cunho satisfativo): "tanto a medida cautelar propriamente dita como a medida antecipatória representam providências, de natureza emergencial, executiva e sumária, dotadas em caráter provisório. O que, todavia, as distingue, em substância, é que a tutela cautelar apenas assegura uma pretensão, enquanto a tutela antecipatória realiza de imediato a pretensão" (THEODORO JÚNIOR, Humberto. Processo cautelar, cit., p. 43-83). A respeito de outras medidas preventivas e não cautelares previstas no processo penal, v. LIMA, Marcellus Polastri. Algumas medidas preventivas, mas não cautelares, no processo penal, cit., p. 225-244.

${ }^{274}$ BADARÓ, Gustavo Henrique Righi Ivahy. Medidas cautelares patrimoniais no processo penal, cit., p. 175.
} 
geral de cautela do Juiz a permitir a concessão de medidas constritivas atípicas, da mesma forma como é admitido no processo civil ${ }^{275}$.

As medidas cautelares patrimoniais penais existentes no ordenamento jurídico brasileiro são ${ }^{276}$ : a) Sequestro de bens imóveis adquiridos pelo indiciado com os proventos da infração (art. 125 a 132, CPP); b) Sequestro de bens móveis obtidos com os proventos da infração e que não possam ser objeto de busca e apreensão (art. 132, CPP) ${ }^{277}$; c) especialização e registro da hipoteca legal (art. 134, CPP), que recai sobre bens imóveis lícitos $^{278}$ - do acusado, com o objetivo de futuro ressarcimento do dano causado pelo delito, bem como ao pagamento das despesas processuais e eventual pena de multa. A legitimação é, em regra, somente do ofendido e seus sucessores (art. 134, CPP ${ }^{279}$; d) arresto de bens imóveis prévio à hipoteca legal, que serve para possibilitar outra medida cautelar, a especialização e o registro da hipoteca legal, e tem prazo de eficácia definido: é revogado no prazo de 15 dias se não for promovido o processo de registro da hipoteca legal (art. 136, CPP); e) arresto subsidiário dos bens móveis ${ }^{280}$ (art. 136, CPP), que é cabível quando o acusado não possuir bens imóveis ou os possuir de valor insuficiente e incide sobre bens suscetíveis de penhora ${ }^{281}$.

O Código de Processo Penal brasileiro, com sua redação original conferida pelo legislador de 1941, trazia imperfeições conceituais e terminológicas no que diz respeito às medidas cautelares patrimoniais, com destaque para a confusão entre os termos "sequestro" e "arresto" e, por isso, sofreu críticas pela doutrina e jurisprudência ${ }^{282}$.

A Lei 11.435, de 28 de dezembro de 2006, buscou amenizar os deslizes cometidos pelo legislador de 1941, alterando o Código de Processo Penal. Assim, porque recaem sobre o patrimônio lícito do acusado com a finalidade de garantir o ressarcimento

${ }^{275}$ BADARÓ, Gustavo Henrique Righi Ivahy. Medidas cautelares patrimoniais no processo penal, cit., p. 175.

${ }^{276}$ Adotamos a classificação usada por: BADARÓ, Gustavo Henrique Righi Ivahy. Medidas cautelares patrimoniais no processo penal, cit.

${ }^{277}$ Bens móveis que constituam o produto do crime e que podem ser apreendidos, como, por exemplo, a coisa furtada, devem ser apreendidos e não sequestrados, quer por se tratar de coisas obtidas por meio criminoso, quer por ser necessário à prova da infração (art. 240, parágrafo 1", "b" e "c" , do Código de Processo Penal).

${ }^{278} \mathrm{Se}$ o imóvel foi obtido ilicitamente, seja ele provento direto ou indireto da infração, deverá ser objeto de sequestro (art. 135, CPP) e não de especialização e registro da hipoteca legal.

${ }^{279}$ Significa que a especialização e registro da hipoteca legal não pode ser requerida pelo Ministério Público, não pode ser decretada em razão de representação da autoridade policial, nem, tampouco, pode ser decretada de ofício pelo juiz.

${ }^{280}$ Exige-se que o acusado não possua bens imóveis ou que os possua de valor insuficiente, por isso é subsidiário do arresto prévio ao registro da hipoteca legal.

${ }^{281}$ Os bens suscetíveis de penhora são aqueles não elencados entre as vedações do artigo 649 do Código de Processo Civil.

${ }^{282}$ BADARÓ, Gustavo Henrique Righi Ivahy. Medidas cautelares patrimoniais no processo penal, cit., p. 178. 
pelo dano causado pela prática delituosa, passaram a ser chamados corretamente de arresto o que, antes, era chamado de "sequestro" prévio ao registro da hipoteca legal e "sequestro" subsidiário dos bens móveis.

A lei $n^{\circ}$ 9.613, de 3 de março de 1998, que versa sobre o crime de lavagem de capitais, recentemente alterada pela Lei ${ }^{\circ}$ 12.683/2012, também prevê a decretação de "medidas assecuratórias de bens, direitos ou valores do investigado ou acusado, ou existentes em nome de interpostas pessoas, que sejam instrumento, produto ou proveito dos crimes previstos nesta lei ou das infrações penais antecedentes".

Último aspecto se refere aos requisitos relativos ao fumus comissi delicti e periculum in mora.

Na sistemática do Código de Processo Penal, o fumus comissi delicti desdobrase no juízo positivo a respeito da prova da materialidade delitiva e na autoria, mesmo se baseados em indícios ${ }^{283}$. Assim, para a decretação de uma providência cautelar, na fase de inquérito policial ou de ação penal, deve o magistrado analisar a existência de elementos sérios, concretos e convergentes no sentido de apontar a existência de uma infração penal e de sua respectiva autoria.

Absurdo seria, logicamente, se este juízo significasse um pré-julgamento do mérito. Dispensa reprisar que eventual elucubração sobre a procedência da ação penal só cabe ao final daquela. Assim, quaisquer avaliações judiciais para a análise dos requisitos da tutela cautelar no processo penal encontram limite na proteção constitucional à presunção de inocência.

Destarte, para verificação do fumus comissi delicti, o que o juiz deve analisar é se há elementos indiciários suficientes a confirmar a efetiva ocorrência de um crime e seu respectivo autor.

No tocante ao requisito do periculum in mora, exige-se, de maneira geral, dano concreto às medidas cautelares patrimoniais no âmbito do processo civil ${ }^{284}$, mas simples dano marginal às medidas cautelares patrimoniais no processo penal.

\footnotetext{
${ }^{283}$ GIMENES, Marta Cristina Cury Saad. As medidas assecuratórias do Código de Processo Penal como forma de tutela cautelar destinada à reparação do dano causado pelo delito, cit., p. 37. No mesmo sentido: LOPES JR., Aury. Introdução crítica ao processo penal: fundamentos da instrumentalidade constitucional, cit., p. 200; DELMANTO, Fábio Machado de Almeida. Medidas substitutivas e alternativas à prisão cautelar, cit.

284، Para obtenção da tutela cautelar, a parte deverá demonstrar fundado temor de que, enquanto aguarda a
} 
Da leitura do capítulo VI do Código de Processo Penal, que disciplina as medidas assecuratórias, permite-se concluir que a decretação de medidas cautelares patrimoniais prescindem da ocorrência comprovada de fatos que coloquem em risco a garantia de reparação do dano causado pelo delito.

Para a decretação do sequestro, "basta existência de indícios veementes da proveniência ilícita dos bens" (art. 126, CPP). A hipoteca legal pode ser requerida pelo ofendido em qualquer fase do processo, "desde que haja certeza da infração e indícios suficientes da autoria" (art. 134, CPP). O arresto de bens imóveis pode ser decretado de início e revogado, se não for promovido processo de inscrição da hipoteca legal (art. 136, CPP). Já o arresto de bens móveis suscetíveis de penhora é admitido "se o responsável não possuir bens imóveis ou os possuir de valor insuficiente" (art. 137, CPP).

Com efeito, interpretação literal dos dispositivos legais supramencionados conduz à conclusão de que é desnecessária a alegação - tampouco a demonstração - do periculum in mora $^{285}$. Em nenhum momento se exige fundado e concreto temor de o patrimônio do acusado ser dispersado ou esvaziado para frustrar a reparação dos danos causados pela prática delituosa, como efeito automático de futura e eventual sentença penal condenatória.

Também não é preciso investigação substancial sobre o acervo patrimonial do acusado, para se provar, $v . g$., a suficiência ou insuficiência patrimonial do acusado para garantir o quantum a ser exigido a título de reparação de dano. Apenas o pedido da especialização da hipoteca legal deve ser instruído com as provas em que se fundar a estimação da responsabilidade e com a relação dos imóveis que o responsável possuir (art. 135, $\left.\S 1^{\circ}, \mathrm{CPP}\right)$.

Assim, no processo penal brasileiro, não é necessária a alegação nem tampouco a demonstração do periculum, que é simplesmente deduzida pelo legislador em razão

\footnotetext{
tutela definitiva, venham a faltar as circunstâncias de fato favoráveis à própria tutela. E isto pode ocorrer quanto haja risco de perecimento, destruição, desvio, deterioração ou de qualquer mutação das pessoas, bens ou provas necessários para a perfeita e eficaz atuação do provimento final do processo principal". O receio de dano deve ser fundado, obtido da análise objetiva das causas postas em existência. Não é preciso prova nem certeza do perigo - até porque a cognição deve ser sumária - e, sim, justificação, ou seja, plausibilidade. É dos fatos provados que resulta a plausibilidade de perigo, malgrado a lei presuma a existência do perigo em alguns casos. (THEODORO JÚNIOR, Humberto. Processo cautelar, cit., p. 7678). No mesmo sentido salienta JosÉ RoberTo dos SANTOS BEDAQUE: “A tutela sumária, definitiva ou provisória, destinada a evitar o dano marginal, sem qualquer nexo com algum perigo concreto, é absolutamente excepcional e só pode ser admitida se expressamente prevista" (Tutela cautelar e tutela antecipada: tutelas sumárias e de sistematização, cit., p. 272).

${ }^{285}$ Conf. GIMENES, Marta Cristina Cury Saad. As medidas assecuratórias do Código de Processo Penal como forma de tutela cautelar destinada à reparação do dano causado pelo delito, cit., p. 52.
} 
simplesmente do decurso do inter processual. Dispensa-se a demonstração da ocorrência de efetivo e concreto risco de dano irreparável e de difícil reparação, associado à morosidade do processo. Tal cenário tem sido alvo de profundas críticas da doutrina ${ }^{286}$.

\subsubsection{Medidas cautelares patrimoniais na legislação comparada}

\subsubsection{Itália}

No que tange à coordenação das esferas civil e penal, a Itália adota o chamado sistema da livre escolha, que estabelece a faculdade de cumular as ações civil e penal no mesmo juízo criminal, ou fazê-las correr separadamente em suas respectivas instâncias ${ }^{287}$. Nesse sentido, dispõe o art. 74 do Código de Processo Penal Italiano que “a ação civil de restituição e compensação por danos pode ser intentada no processo criminal

\footnotetext{
${ }^{286}$ No entendimento de GIMENES, "é preciso circunscrever o conteúdo de periculum in mora a fim de que não constitua o perigo genérico, derivado simplesmente da duração do inter procedimental. É necessária informação sobre medidas concretas das quais se possa deduzir uma provável transformação de dano temido em dano efetivo, decorrente da demora da prestação jurisprudencial. Por isso, o periculum in mora deve se fundar em fatos objetivos, e não em conjecturas subjetivas". Segundo a autora, no processo penal, para a configuração do periculum in mora, deve haver a "ocorrência de um dano irreparável ou de difícil reparação, ligada à morosidade". Especificadamente às medidas cautelares reais, deve o juiz verificar a ocorrência de três situações: inadequação do patrimônio do acusado se comparado ao quantum relativo ao dano causado na vítima; insuficiência de seu patrimônio frente a possíveis credores; e o temor de dispersão ou diminuição do patrimônio. (As medidas assecuratórias do Código de Processo Penal como forma de tutela cautelar destinada à reparação do dano causado pelo delito, cit., p. 55-56). Importante trazer à colação os ensinamentos de ROGÉRIO LAURIA TUCCI et. al., no sentido de que as medidas cautelares processuais penais são "instrumentos a serem utilizados excepcionalmente, quando houver risco à segurança do processo. Tal risco é ditado por fatos extrínsecos ao mérito do processo, dos quais podem decorrer dano grave ao reconhecimento e ulterior satisfação do direito pleiteado (...). Somente quando houver probabilidade de dano irreparável ao processo ou ao direito que por meio dele se pleiteia, é que se pode deferir a medida cautelar. Se a providência for determinada sem que se avalie a necessidade de segurança, não estaremos diante de autêntica medida cautelar, mas de odiosa antecipação dos efeitos da condenação" (Sistematização das medidas cautelares processuais penais, cit., p. 115). No sentido de que é preciso a demonstração de risco concreto de dano ao processo: SÁNCHEZ RIOS, Rodrigo. Da limitada utilização do arresto cumulado com medida de especialização de hipoteca legal no processo penal pátrio. Revista do Curso de Mestrado em Direito, Presidente Prudente, v. 2, n. 2, p. 317-329, dez. 2001; e GONÇALVES, Marianna Moura. Prisão e outras medidas cautelares pessoais à luz da proporcionalidade, cit., p. 178-179. Especificadamente sobre as medidas cautelares pessoais, para a verificação do periculum libertatis, "deverá ser aferida a ocorrência de perigo concreto que a manutenção da liberdade do acusado representa para a instrução processual ou para a futura aplicação da pelo penal (seus requisitos)" (DELMANTO JÚNIOR, Roberto. As modalidades de prisão provisória e seu prazo de duração. 2. ed. Rio de Janeiro: Renovar, 2001. p. 84). Também para ANTÔNIO MAGALHÃES GOMES FILHO, é “indispensável que se demonstre cabalmente a ocorrência de fatos concretos que indiquem a necessidade da medida por exigências cautelares de tipo instrumental ou final" (Presunção de inocência e prisão cautelar, cit., p. 81).

287، La soluzione per cosi dire eclettica che il codice ha dato al problema può definir-se come tradizionali nelle sue scelte di fondo, però accompagnata da qualche novità nei profili più particolari della disciplina. Il danneggiato ha la facoltà di esercitare l'azione civile nel processo penale costituendosi parte civile, ovvero di esercitare l'azione civile avanti al giudice civile. Nessuna di queste due scelte à tuttavia irreversibile, essendo altresì prevista, entro certi limiti e con vari effetti, la facoltà di trasferire l'azione dall'una all'altra sede." (PISANI, Mario et al. Manuale di procedura penale, cit., p. 113).
} 
pelo sujeito a quem o crime tenha prejudicado ou por seus sucessores universais contra o acusado e responsável civil" ${ }^{288}$.

Assim, pessoa física ou jurídica que sofre um dano de ordem patrimonial ou não patrimonial decorrente do crime ("danneggiato",289) pode exercer, no processo penal, a ação civil com vistas à obtenção do ressarcimento do dano. Neste caso, tal pessoa passa a ser constituída no processo penal como "parte civil", exercitando, concomitantemente à ação penal, poderes civis tendentes a tutelar seu interesse na obtenção da condenação do acusado ao ressarcimento do dano ${ }^{290}$.

O exercício da ação civil no processo penal italiano atende a dois critérios fundamentais. Primeiro, a ação civil mantém sua natureza e características como ação de natureza privada e civil: é facultativa e disponível, estando a condenação do acusado à reparação do dano adstrita aos limites do pedido formulado na exordial. Segundo, há a prevalência das normas do processo penal, de sorte que a atuação do ofendido como parte (civil) no processo é regida pelas normas processuais penais, ainda que no âmbito de uma ação civil reparatória ${ }^{291}$. Ou seja, a ação civil é "hospedada" no processo penal ${ }^{292}$, devendo adaptar-se às regras deste.

O antigo Código de Processo Penal italiano previa a hipoteca legal dos bens imóveis do acusado. Na ausência de bens imóveis, ou se fossem insuficientes, caberia o "sequestro conservativo", instituto equivalente ao nosso arresto. Para fins probatórios também havia o chamado "sequestro penal" de bens, próximo à busca e apreensão brasileira. Os bens móveis apreendidos no sequestro penal, se não mais interessassem à demonstração do crime, poderiam servir como garantia patrimonial, hipótese em que o sequestro penal era convertido em sequestro conservativo ${ }^{293}$.

\footnotetext{
${ }^{288}$ Tradução livre de: "l'azione civile per le restituzione e per risarcimento del danno (...) può essere esercitata nel processo penale dal soggetto al quale il reato ha recato danno ovvero dai suoi successori universali, nei confronti dell'imputato e del responsabile civile".

${ }^{289}$ Os termos "danneggiato" e "persona offesa" possuem conceitos distintos. A "persona offesa" (ofendido) do crime é o titular do bem jurídico protegido pela norma incriminadora que se tem por violada em decorrência do crime. A persona offesa é sujeito do processo penal, mas também pode se tornar parte se, assumindo as vestes de "danneggiato" (civilmente prejudicado) pelo crime, exerce o direito à ação reparatória, habilitando-se como parte civil ("parte civile").

${ }^{290}$ TONINI, Paolo. Manuale breve diritto processuale penale: tutto il programma d'esame con domande e risposte commentate. Milano: Giuffrè, 2009. p. 102.

${ }^{291}$ TONINI, Paolo. Manuale breve diritto processuale penale: tutto il programma d'esame con domande e risposte commentate, cit., p. 103.

${ }^{292}$ PISANI, Mario et al. Manuale di procedura penale, cit., p. 112.

${ }^{293}$ FERNANDES, Antonio Scarance. O papel da vítima no processo criminal, cit., p. 198.
} 
Após a reforma ao Código de Processo Penal italiano, existem hoje duas modalidades de cautelar patrimonial: sequestro conservativo (artigos 316 a 320) e sequestro preventivo (artigos 321 a 323). A antiga hipoteca legal foi eliminada ${ }^{294}$.

O sequestro conservativo pode se voltar contra bens móveis ou imóveis do acusado - neste último, em substituição à hipoteca legal da lei processual anterior. Como medida cautelar de natureza real, o sequestro conservativo exerce função de garantia patrimonial. Podem ser sequestrados todos os bens suscetíveis de penhora, tais como dinheiro, ações, cotas sociais, contas bancárias e imóveis em geral. Os bens da pessoa física não podem ser objeto de sequestro conservativo em decorrência da violação de norma tributária imputada à pessoa jurídica ${ }^{295}$.

Ademais, o sequestro conservativo pode ser requerido em qualquer estado ou grau do processo. É legitimado a requerer o sequestro conservativo dos bens do acusado o Ministério Público, no interesse de garantir o pagamento da pena pecuniária, das despesas processuais e de outras dívidas ao Estado. Se estiver constituído como parte civil, o particular ofendido também adquire legitimidade para pedir o sequestro como garantia ao ressarcimento do dano causado pela prática delituosa (artigo 316, n. 1 a 3). O sequestro requerido pelo Ministério Público aproveita também ao ofendido.

O sequestro conservativo é decretado inaudita altera pars por sentença que deve ser motivada com base em dados concretos, sendo insuficiente a alusão a genérico e indeterminado perigo de dispersão do patrimônio ${ }^{296}$.

Importante destaque do sistema processual italiano encontra-se, pois, como observa MARTA CRISTINA CURY SAAD GIMENES, na exigência de se demonstrar o periculum in mora. Diferentemente da realidade brasileira, na sistemática das cautelares patrimoniais na Itália, exige-se, à decretação do sequestro conservativo, "fundadas razões de que haja depauperamento (insuficiência ou inadequação) ou dispersão dos bens que

\footnotetext{
${ }^{294}$ O CPP italiano ainda prevê uma terceira espécie de sequestro, o sequestro probatório (artigos 253 a 265), que não é considerado medida cautelar patrimonial propriamente dita, pois tem a finalidade de assegurar a prova sobre o corpo de delito e sobre as coisas pertinentes ao crime. Portanto, equipara-se à nossa busca e apreensão (GIMENES, Marta Cristina Cury Saad. As medidas assecuratórias do Código de Processo Penal como forma de tutela cautelar destinada à reparação do dano causado pelo delito, cit., p. 181-182).

${ }^{295}$ GIMENES, Marta Cristina Cury Saad. As medidas assecuratórias do Código de Processo Penal como forma de tutela cautelar destinada à reparação do dano causado pelo delito, cit., p. 183.

${ }^{296}$ GIMENES, Marta Cristina Cury Saad. As medidas assecuratórias do Código de Processo Penal como forma de tutela cautelar destinada à reparação do dano causado pelo delito, cit., p. 183.
} 
possam garantir o pagamento das penas pecuniárias, das despesas do processo e das obrigações civis decorrentes do crime" 297.

Após o trânsito em julgado da sentença penal condenatória ao pagamento de pena pecuniária, ou quando se torna executiva a sentença que condena o réu e o responsável civil ao ressarcimento do dano em favor da parte civil, o sequestro conservativo é convertido em penhora. Semelhantemente ao nosso arresto, a pretensão ao ressarcimento civil no sequestro conservativo prevalece sobre o pagamento da pena pecuniária (artigo 320 e 316, n. 4).

Já o sequestro preventivo pode recair sobre bem móvel e imóvel que faça parte do corpo de delito ou pertença ao crime, ou seja, sobre coisas relacionadas ao crime, as quais, se permanecerem em poder de seu proprietário, são suscetíveis a prolongar as consequências do próprio delito ou a estimular a prática de outros crimes.

O Código de Processo Penal Italiano prevê três hipóteses para o sequestro preventivo: a) quando a disponibilidade da coisa pode agravar as consequências do delito; b) quando há o perigo de que o bem seja utilizado para a prática de outro crime; c) quando o bem, em si, apresenta periculosidade (artigo 321). Trata-se de medida, sobretudo para fins de prevenção e de confisco.

São legitimados para requerer o sequestro conservativo o Ministério Público e a polícia judiciária. A decretação da medida, pelo juiz, deve ser motivada, sob pena de nulidade $^{298}$. A parte civil não é legitimada a pedir o sequestro preventivo ${ }^{299}$.

\subsubsection{Portugal}

Já Portugal, quanto à relação entre as esferas civil e penal, adota o sistema da solidariedade, unidade ou interdependência das instâncias, pelo qual a reparação do dano e a aplicação da pena são obtidas por meio de duas ações, civil e penal, ajuizadas em um único processo e julgadas simultaneamente pelo mesmo juiz penal. Dispõe o artigo 29 do CPP português: "o pedido de indemnização por perdas e danos resultantes de um facto punível, por que sejam responsáveis os seus agentes, deve fazer-se no processo em que

\footnotetext{
${ }^{297}$ GIMENES, Marta Cristina Cury Saad. As medidas assecuratórias do Código de Processo Penal como forma de tutela cautelar destinada à reparação do dano causado pelo delito, cit., p. 183.

${ }^{298}$ GIMENES, Marta Cristina Cury Saad. As medidas assecuratórias do Código de Processo Penal como forma de tutela cautelar destinada à reparação do dano causado pelo delito, cit., p. 184.

${ }^{299}$ PISANI, Mario et al. Manuale di procedura penale, cit., p. 329.
} 
ocorrer a acção penal e só poderá ser feito separadamente em acção intentada nos tribunais civis nos casos previstos neste código". Ainda prevê o artigo 34 que "o juiz, no caso de condenação, arbitrará aos ofendidos uma quantia como reparação por perdas e danos, ainda que lhe não tenha sido requerida" 300 .

Em razão do sistema adotado da unidade de instâncias, a doutrina portuguesa dominante considera a reparação civil ao lesado imposta como efeito penal da condenação uma decisão em coisa cível, ou seja, verdadeira indenização cível de perdas e danos. Assim, deixa de existir, da parte do lesado, qualquer interesse processual capaz de legitimar o seu posterior recurso ao processo $\mathrm{civil}^{301}$.

O Código de Processo Penal português prevê duas modalidades de medidas cautelares patrimoniais: caução econômica (artigo 227) e arresto preventivo (artigo 228).

De acordo com o art. 227 do CPP português, o Ministério Público é legitimado a requerer ao acusado que preste caução econômica, quando houver fundado receio de que faltem ou diminuam substancialmente as garantias pecuniárias, das custas do processo ou de qualquer outra dívida para com o Estado relacionada com o crime. O ofendido pode igualmente requerer a caução econômica ao acusado ou ao civilmente responsável, se tiver fundado receio de que faltem ou diminuam substancialmente as garantias de pagamento de indenização ou de outras obrigações civis decorrentes da prática criminosa. A caução econômica requerida pelo Ministério Público aproveita também ao particular ofendido ${ }^{302}$.

A caução econômica oferecida pelo acusado subsiste até que haja decisão final absolutória ou até decisão extintiva das obrigações. Em caso de condenação, o valor garantido pela caução será levantado para pagar, sucessivamente, eventual multa, taxa de justiça, custas processuais, indenização do ofendido e outras obrigações civis ${ }^{303}$. Portanto, em contraponto ao sistema brasileiro - e, como visto, ao italiano -, no modelo português de

\footnotetext{
${ }^{300}$ Nesse sentido, v. DIAS, Jorge de Figueiredo. Direito processual penal. Coimbra: Coimbra Ed., 2004. p. 542. Segundo o autor, o fundamento para a escolha do modelo de dependência processual do pedido de indenização civil perante o processo penal tem por base o "interesse social existente na obrigatoriedade de o delinquente reparar o prejuízo civil que causou com o crime: o dano ex delicto, essencialmente diverso do dano ex contracto e subsistente em qualquer infração penal, deveria ser sempre e obrigatoriamente reparado no interesse da defesa social...". Há, ainda, outras razões, como economia processual, proteção ao lesado e auxílio à função repressiva do direito penal (p. 543).

${ }^{301}$ DIAS, Jorge de Figueiredo. Direito processual penal, cit., p. 545.

${ }^{302}$ GIMENES, Marta Cristina Cury Saad. As medidas assecuratórias do Código de Processo Penal como forma de tutela cautelar destinada à reparação do dano causado pelo delito, cit., p. 190.

${ }^{303}$ GIMENES, Marta Cristina Cury Saad. As medidas assecuratórias do Código de Processo Penal como forma de tutela cautelar destinada à reparação do dano causado pelo delito, cit., p. 190.
} 
caução econômica, a satisfação do dano à vítima não prevalece sobre o pagamento da pena pecuniária e das custas processuais.

O arresto preventivo, previsto no artigo 228 do CPP português, pode ser decretado pelo juiz a pedido do Ministério Público ou do ofendido, nos termos da lei processual civil. De acordo com o artigo 406 do Código de Processo Civil português, o arresto dos bens do devedor é medida ao alcance do credor, quando este tem justificado receio de perda da garantia patrimonial de seu crédito.

Em resumo, o arresto é a tomada judicial dos bens do devedor ${ }^{304}$. O requerente do arresto deve deduzir fatos que tornem provável a existência do crédito e, principalmente, justifiquem o receio invocado, devendo, ainda, relacionar os bens que devem ser constritos, com todas as indicações necessárias à realização da diligência (artigo 407).

Também é cabível o arresto quando imposta a caução econômica e esta não for prestada pelo acusado. Neste caso, incidirá a presunção iuris tantum da existência de fundado receio de perda da garantia patrimonial, de modo que o requerente da medida, seja o Ministério Público, seja o particular ofendido, ficam dispensados de comprová-la. Neste caso, forma-se privilégio a favor dos créditos ex delicto em relação a todos os outros créditos, inclusive com preferência sobre o pagamento da multa penal.

Analisados os fatos deduzidos e os elementos apresentados como prova ao direito reclamado pelo credor, o arresto é decretado inaudita altera pars. A garantia deve ser fixada no limite suficiente para a segurança do crédito, excetuando-se os proventos indispensáveis aos alimentos e à subsistência do credor e de seus familiares (art. 408).

O arresto é extinto se, com o trânsito em julgado da sentença que reconhece a obrigação do devedor à indenização pelo dano causado, o credor não promove a execução no prazo de dois meses, ou, se promovida a execução, o processo fica sem andamento durante mais de trintas dias, por desídia do exequente. Ademais, o arresto pode ser revogado a qualquer tempo se o acusado ou o responsável civil prestarem a caução econômica imposta.

\footnotetext{
${ }^{304}$ GIMENES, Marta Cristina Cury Saad. As medidas assecuratórias do Código de Processo Penal como
} forma de tutela cautelar destinada à reparação do dano causado pelo delito, cit., p. 190. 


\subsection{Conclusões do capítulo}

Não é possível ignorar a existência de diferentes opções de direito processual penal e, consequentemente, de diversos modelos de tutela cautelar. Em decorrência do caráter acessório do processo cooperacional em relação ao processo principal estrangeiro, a identificação dessas diferenças, pelo Estado requerido, como fator de relevância pode influenciar negativamente o fluxo cooperacional.

As diferenças tornam-se menos tormentosas na medida do desenvolvimento da assistência jurídica. Do tradicional paradigma do soberanismo ao da mútua confiança, quanto menores a intolerância externa e a exigência de correspondência entre sistemas para a consecução dos pleitos cooperacionais, maior tende ser a aproximação dos sistemas e, por isso, menor a relevância das diferenças entre as opções de processo penal.

Mesmo no paradigma da mútua confiança, estágio atual da União Europeia, a inexistência de um processo penal europeu no âmbito da supranacionalidade conduz ao tratamento de questões processuais penais ainda no âmbito interno dos Estados, fazendo perpetuar eventuais desconexões entre os sistemas europeus, apesar dos esforços.

Diferenças sempre existirão. Por isso, mais proveitoso seria pautar os pleitos cooperacionais nos standards mínimos de garantias estabelecidos pelas normas internacionais humanitárias, pois estabelecem pontos de contato entre as várias opções de direito processual penal. 


\section{MEDIDAS CAUTELARES PATRIMONIAIS PENAIS NO CONTEXTO DA COOPERAÇÃO JURÍDICA INTERNACIONAL}

\subsection{A contextualização das medidas cautelares patrimoniais ao tema da cooperação jurídica internacional em matéria penal}

Um dos principais efeitos da globalização foi a internacionalização do Direito, com a consequente celebração de um número impressionante de tratados e convenções internacionais a partir da segunda metade do século passado. Na União Europeia, diretrizes e decisões-quadro buscam a harmonização de normas penais e processuais penais, e até mesmo se pensou na criação de uma constituição europeia.

Esse processo de internacionalização do Direito também vem acompanhado da internacionalização do crime. Vive-se diante de uma criminalidade que não respeita fronteiras geográficas. A facilidade dos meios de transporte cada vez mais ágeis, o livre acesso às redes públicas de informação (internet) e a aproximação das fronteiras nacionais criaram um cenário propício à transnacionalização dos delitos ${ }^{305}$.

Assim, delitos passaram a ter efeitos em outros Estados. Uma vez que se mostrou difícil reprimir o crime no âmbito interno - em virtude da internacionalização do delito -, o esforço da comunidade internacional voltou-se também à perseguição dos efeitos e proventos do crime, como forma de reprimir essa criminalidade transnacional. Ou seja, na dificuldade de se combater o fato criminoso, volta-se contra o pós-fato criminoso,

\footnotetext{
${ }^{305}$ Como bem explica SÉRgIO FERnANDO MORO: “O mundo tornou-se pequeno. As facilidades tecnológicas de comunicação e de transmissão de dados diminuíram significativamente a distância entre os países e as pessoas, tornando todos os membros de uma mesma aldeia global. De forma semelhante, tais facilidades de comunicação e de transmissão de dados incrementam a rapidez do fluxo financeiro entre os países e as pessoas, com a formação de verdadeiro sistema financeiro internacional. O que ocorre na Bolsa de Valores de Nova York ou na de outros centros financeiros repercute nos principais mercados mobiliários do mundo e vice-versa. Investidores aplicam seus recursos não mais apenas em ativos localizados em um único país, mas igualmente em uma base global. Tais facilidades, além de incrementarem a eficiência da economia mundial e, indiretamente, resultarem em maior bem estar mundial, a despeito dos problemas ambientais e de desigualdade de riquezas tiveram o efeito colateral e indesejado de facilitar a atividade criminosa. Com efeito, aos criminosos abriram-se oportunidades para ocultar mais rapidamente e de maneira eficaz os seus ganhos das autoridades públicas. Em um piscar de olhos ou no apertar de uma tecla, pode o criminoso enviar o produto de sua atividade a um país distante daquele no qual o crime foi praticado, não raramente impossibilitando o rastreamento através da prática de contínuas e complexas transações financeiras ou corporativas" (Cooperação jurídica internacional em casos criminais: considerações gerais, cit., p. 15-16).
} 
como, por exemplo, com o combate à lavagem de dinheiro e a previsão, nos tratados, da adoção de medidas de bloqueio de bens.

Os tratados internacionais tiveram papel relevante, pois somente através da cooperação jurídica internacional seria possível atingir tal intento. Foi nesse contexto, de estrangular a criminalidade perseguindo os efeitos, produtos e proventos do crime, que se intensificaram os fluxos cooperacionais com o objetivo de cumprir, em outro Estado, medidas cautelares patrimoniais para bloqueio de bens, a garantir a utilidade e a eficácia do processo estrangeiro principal.

Logicamente, não faria sentido algum identificar os produtos e proventos do crime em outro país se não houvesse medida de bloqueá-los. Esse cenário implementou em muito o desenvolvimento da cooperação jurídica internacional.

A título de exemplo, um indivíduo que comete determinado crime no Brasil pode perfeitamente remeter ao exterior os proventos obtidos com a prática delituosa, no intuito de blindá-los contra futura e eventual condenação penal ${ }^{306}$. Imagine-se, ainda, indivíduo estrangeiro que, após desviar recursos públicos no exterior, transfere parte de seu patrimônio - incluindo o capital obtido na prática delituosa - e investe em bens móveis e imóveis no Brasil, no intuito de desfrutá-los longe do alcance das autoridades de seu país.

Em tais casos, se estiverem os bens do acusado no território de país diverso de onde tramita o processo principal, o cumprimento da medida cautelar patrimonial imposta deverá ser viabilizado através da cooperação jurídica internacional, o que significa dizer: a medida cautelar patrimonial que visa a assegurar resultado útil e eficaz ao processo deverá ser cumprida na jurisdição de outro Estado ${ }^{307}$.

Nestas circunstâncias, a cooperação jurídica internacional visará à adoção de medida urgente e provisória ${ }^{308}$, de natureza cautelar, pela autoridade de um país (Estado requerido) a pedido da autoridade de país estrangeiro (Estado requerente), acarretando

\footnotetext{
${ }^{306}$ Frise-se: são efeitos automáticos da sentença condenatória penal a perda dos proventos e instrumentos do crime e a reparação do dano causado pelo delito.

${ }^{307}$ A cooperação jurídica internacional pode ser usada para o cumprimento de outras medidas cautelares e não apenas as medidas cautelares patrimoniais. Medidas cautelares para fins probatórios também costumam ser objeto de pedidos de cooperação jurídica (por exemplo, para o cumprimento de diligência de busca e apreensão ou quebra de sigilo). Contudo, para os fins da presente dissertação, daremos enfoque apenas nas medidas cautelares patrimoniais cumpridas através da cooperação jurídica internacional.

${ }^{308}$ A cooperação pode ter como objeto a obtenção de um provimento cautelar pela autoridade competente do Estado requerido ou a execução de providências cautelares de acordo com provimento já proferido por autoridade do Estado requerente.
} 
efeito de ordem real ou patrimonial ${ }^{309}$ face o direito patrimonial do indiciado, acusado ou condenado de delito ${ }^{310}$, com o propósito de assegurar eficiência e eficácia ao processocrime cuja jurisdição está a cargo do país solicitante da medida.

Medidas cautelares patrimoniais cumpridas por meio da cooperação jurídica internacional podem incidir sobre bens móveis e imóveis, direitos e valores; têm natureza provisória e podem ou não acarretar a transferência imediata do bem (ou do montante correspondente à sua venda), direito ou do valor constrito ao Estado requerente ${ }^{311}$.

A assistência jurídica internacional pode consistir num pedido de execução de decisão judicial estrangeira, geralmente interlocutória, pela indisponibilidade de bens, direitos e valores ou pela alienação cautelar de bens ${ }^{312}{ }^{313}$. Ao invés de pedir a execução de decisão judicial estrangeira, pode-se solicitar que a autoridade competente do Estado requerido decida, ela própria, sobre a adoção ou não das medidas necessárias ao confisco ou indisponibilidade de bens (o que fará com base nas informações recebidas pelo Estado requerente) e que a execute, caso decida pela constrição cautelar.

Assim, com base em tratado internacional (multilateral ou bilateral), ou, na ausência deste, mediante promessa de reciprocidade ${ }^{314}$, o país "A”, que detém a jurisdição

\footnotetext{
${ }^{309} \mathrm{Na}$ media em que incide sobre bens móveis ou imóveis, direitos ou valores (BECHARA, Fábio Ramazzini; ARAÚJO, Marcilândia. Medidas de cooperação reais. In: FERNANDES, Antonio Scarance; ZILLI, Marcos Alexandre Coelho (Coord.). Direito processual penal internacional. São Paulo: Atlas, 2013. p. 448).

${ }^{310}$ As medidas cautelares processuais penais podem ser decretadas, quer na fase de inquérito policial, quer na fase de ação penal. Justifica-se, portanto, os diferentes termos para identificar as diferentes fases em que as medidas cautelares reais podem ser objeto de cooperação jurídica internacional: "indiciado" (durante a fase de inquérito policial, já havendo indícios de autoria e prova da materialidade delitiva); "acusado" (durante a ação penal e antes de sentença penal condenatória); "condenado" (durante a ação penal e após sentença condenatória ainda não transitada em julgado).

${ }^{311}$ BECHARA, Fábio Ramazzini; ARAÚJO, Marcilândia. Medidas de cooperação reais, cit., p. 488.

${ }^{312}$ BECHARA, Fábio Ramazzini; ARAÚJO, Marcilândia. Medidas de cooperação reais, cit., p. 488.

${ }^{313}$ Importante mencionar que as medidas reais previstas nos tratados internacionais são de duas ordens: a) execução de decisão judicial definitiva para perda ou confisco definitivo de bens, direitos ou valores. $\mathrm{O}$ cumprimento dessa medida visa à execução de pena de confisco ou ao cumprimento dos efeitos automáticos da sentença penal condenatória transitada em julgado; b) execução de decisão judicial interlocutória para o bloqueio provisório de bens, direitos ou valores, com o propósito de garantir futuro confisco definitivo. Trata-se de medida de natureza cautelar patrimonial. Na presente dissertação, não estudaremos as medidas de natureza definitiva e não cautelar em assistência jurídica internacional, como confisco ou perda final dos proventos e instrumentos do crime.

${ }^{314}$ Nesse sentido: “(...) mesmo que não exista qualquer acordo ou tratado internacional a embasar o pedido de assistência, os países envolvidos na cooperação, no exercício de sua soberania e competência, podem perfeitamente negociar e acordar pontualmente a possibilidade do auxílio mútuo, com fundamento no princípio da reciprocidade" (BECHARA, Fábio Ramazzini; ARAÚJO, Marcilândia. Medidas de cooperação reais, cit., p. 488).
} 
sobre o processo principal ${ }^{315}$, pode solicitar a assistência jurídica do país "B", onde se localizam os bens, direitos ou valores do acusado, visando a bloqueá-los cautelarmente.

Conforme demonstramos, no país "B”, o pedido de assistência judicial dará origem a um processo cooperacional, no qual, em uma relação trilateral - que envolve Estado requerente, Estado requerido e o indiciado, acusado ou condenado -, deverão ser asseguradas as garantias fundamentais da pessoa atingida pela medida solicitada.

Essa interação interjurisdicional ${ }^{316}$ de natureza processual penal internacional não se tornaria viável sem a conscientização dos Estados no sentido de aproximar seus sistemas jurídicos, cooperando mutuamente de maneira a otimizar a luta contra a criminalidade transnacional $^{317}$.

A necessidade da cooperação jurídica internacional em matéria penal é fruto do interesse dos Estados no estabelecimento de regras e procedimentos específicos que possibilitem ou agilizem o acesso à jurisdição também "para além das fronteiras"318. Nesse contexto, inúmeros tratados multilaterais e bilaterais ${ }^{319}$ passaram a estabelecer o

${ }^{315}$ A expressão "processo principal” é encontrada no Código de Processo Civil, em seu artigo 796, que trata do processo cautelar: "O processo cautelar pode ser instaurado antes ou no curso do processo principal e deste é sempre dependente".

${ }^{316}$ Cf. CERVINI, Raul; TAVARES, Juarez. Princípios da cooperação judicial penal internacional no Protocolo do Mercosul, cit.

${ }^{317}$ De acordo com a Convenção das Nações Unidas contra o Crime Organizado Transnacional (Decreto $\mathrm{n}$. 5.015, de 12 de março de 2004), considera-se de caráter transnacional a infração que: (i) for praticada em mais de um Estado; (ii) for praticada num só Estado, mas uma parte substancial da sua preparação, planejamento, direção e controle tenha lugar em outro Estado; (iii) for pratica em um só Estado, mas envolvida a participação de um grupo criminoso organizado que pratique atividades criminosas em mais de um Estado; ou (iv) que for praticada num só Estado, mas produza efeitos substanciais noutro Estado (art. $\left.3^{\circ},[2]\right)$.

318“A necessidade da cooperação jurídica internacional resta ainda mais clara considerando que as mudanças tecnológica, políticas e o aumento no deslocamento de pessoas e bens entre fronteiras têm causado maior interesse por parte dos Estados no estabelecimento de regras e procedimentos específicos que possibilitem e facilitem o acesso à justiça para além das fronteiras. Hoje em dia, as partes e as provas de um processo judicial podem estar espalhadas por várias jurisdições. Consequentemente, para dar andamento a seus processos jurídicos, um Estado deve recorrer a outra jurisdição para obter ações por ele buscadas. Em tais situações, a cooperação entre os Estados se transformou em uma das maneiras mais viáveis para resguardar o andamento de sua Justiça. Portanto, um ato de cooperação, que tradicionalmente poderia ser visto como uma violação da soberania dos Estados, hoje em dia, pode ser reconhecido como uma forma de manutenção de um novo conceito de soberania, estabelecido pelas atuais relações entre os Estados. Assim, o direito e o dever de um Estado soberano na manutenção de sua Justiça restariam resguardados" (GENRO, Tarso. A cooperação jurídica internacional e o propósito deste manual. In: MANUAL de cooperação jurídica internacional e recuperação de ativos: cooperação em matéria penal. Brasília: Ministério da Justiça, 2008. p. 12).

${ }^{319}$ Tanto os tratados bilaterais quanto os multilaterais servem de suficiente amparo jurídico à cooperação jurídica internacional. A Convenção das Nações Unidas contra o Crime Organizado Transnacional (Decreto n. 5.015, de 12 de março de 2004) estabelece que as medidas cautelares objeto de cooperação jurídica internacional entre os Estados-partes serão atendidas pelo Estado-parte requerido "em conformidade com o seu direito interno e segundo as disposições do mesmo direito, e em conformidade com as suas regras processuais ou com qualquer tratado, acordo ou protocolo bilateral ou multilateral que o ligue ao Estadoparte requerente" (artigo 13, par. $4^{\circ}$ ). Porém, se a existência de tratado na matéria for requisito para cumprimento da medida pelo Estado-parte requerido e se inexistir tratado bilateral entre os Estados-partes 
compromisso de os Estados cumprirem pedidos de cooperação jurídica que tenham medidas cautelares patrimoniais como objeto ${ }^{320}$.

Os documentos internacionais referidos dão a base jurídica aos pedidos de assistência jurídica. Ademais, como bem observam FÁBIO RAMAZZINI BECHARA e MARCILÂNDIA ARAÚJO, os tratados de natureza cooperacional fornecem "alguns parâmetros a orientar a atuação dos Estados não apenas na revisão e adequação dos sistemas nacionais, mas principalmente nas relações entre si, possibilitando atenuar os eventuais problemas gerados pelas diferenças entre os ordenamentos" ${ }^{\prime 321}$.

Dentre os tratados multilaterais em matéria penal celebrados pelo Brasil que versam sobre medidas cautelares patrimoniais, destacaremos os mais relevantes.

Na Convenção contra o Tráfico Ilícito de Entorpecentes e Substâncias Psicotrópicas (Decreto n. 154, de 26 de junho de 1991), não está explícita a possibilidade de cumprimento de medidas cautelares patrimoniais em assistência jurídica internacional. Infere-se do artigo $5^{\circ}$, par. $2^{\circ}$, entretanto, que cada Estado-parte adotará as medidas necessárias a permitir que suas autoridades competentes decretem a "apreensão preventiva ou o confisco (preventivo) do produto, dos bens, dos instrumentos ou de quaisquer outros elementos, com o objetivo de seu eventual confisco (definitivo)" 322 .

envolvidos, a Convenção das Nações Unidas contra o Crime Organizado Transnacional deverá servir como uma base jurídica necessária e suficiente para efeito da medida rogada (artigo 13, par. $6^{\circ}$ ). Em semelhante sentido, dispõe a Convenção das Nações Unidas contra a Corrupção (Decreto n. 5.687, de 31 de janeiro de 2006), em seu art. 55, par. $6^{\circ}$.

${ }^{320}$ Convenção das Nações Unidas contra o crime organizado transnacional (Decreto $\mathrm{n}^{\mathbf{0}} 5.015$, de 12 de março de 2004), artigo 12, par. $1^{\circ}$; Convenção contra o tráfico Ilícito de entorpecentes e substâncias psicotrópicas (Decreto $n^{\circ} 154$, de 26 de junho de 1991), artigo $5^{\circ}$; Convenção das Nações Unidas contra a corrupção (Decreto $\mathrm{n}^{\circ}$ 5687, de 31 de janeiro de 2006), artigo 31, par. $2^{\circ}$; na Convenção Interamericana sobre assistência mútua em matéria penal (Decreto $\mathrm{n}^{\circ}$ 6340, de 3 de janeiro de 2008), artigo 15; Protocolo de assistência jurídica mútua em assuntos Penais - MERCOSUL (Decreto $\mathrm{n}^{\circ}$ 3469, de 17 de maio de 2000), artigo $2^{\circ}$; Protocolo de Medidas Cautelares - MERCOSUL (Decreto $\mathrm{n}^{\mathbf{o}} 27 / 94$ ), artigo $2^{\mathrm{o}}$; Protocolo de San Luis - MERCOSUL (Decreto $\mathrm{n}^{\mathrm{o}}$ 3, de 26 de janeiro de 2000), artigo 22, além dos tratados bilaterais em matéria penal: Brasil-Cuba (Decreto n. 6.462, de 21 de maio de 2008), Brasil-China (Decreto n. 6.282, de 3 de dezembro de 2007), Brasil-EUA (Decreto n. 3.810, de 2 de maio de 2001), Brasil-Colômbia (Decreto n. 3.895, de 23 de agosto de 2001), Brasil-Itália (Decreto n. 862, de 9 de julho de 1993), Brasil-Peru (Decreto n. 3.988, de 29 de outubro de 2001), Brasil-Portugal (Decreto n. 1.320, de 30 de novembro de 1994), Brasil-Coréia do Sul (Decreto n. 5.721, de 13 de maio de 2006), Brasil-Suíça (Decreto n. 6.974, de 7 de outubro de 2009), Brasil-Espanha (Decreto n. 6.681, de 8 de dezembro de 2008), Brasil-Suriname (Decreto n. 6.842, de 29 de abril de 2009), Brasil-Canadá (Decreto n. 6.747, de 22 de janeiro de 2009) e BrasilUcrânia (Decreto n, 5.984, de 12 de dezembro de 2006).

${ }^{321}$ BECHARA, Fábio Ramazzini; ARAÚJO, Marcilândia. Medidas de cooperação reais, cit., p. 449.

${ }^{322}$ A redação original é "confisco do produto..., com o objetivo de eventual confisco". Mesmo sendo empregadas em uma mesma frase, as duas palavras "confisco", a nosso ver, foram empregadas em sentidos diversos. O termo "confisco" na Convenção contra o Tráfico Ilícito de Entorpecentes e Substâncias Psicotrópicas diz respeito à "privação, em caráter definitivo, de algum bem, por decisão de um tribunal ou de outra autoridade competente", art. 1", "e" (destacamos). Portanto, embora seja contraditório retratar 
A Convenção das Nações Unidas contra o Crime Organizado Transnacional (Convenção de Palermo, Decreto n. 5.015, de 12 de março de 2004) obriga os Estadospartes a adotarem, na medida em que o seu ordenamento jurídico interno permitir, o "confisco" 323 - perda final - ou o "bloqueio" 324 ("embargo") - constrição cautelar - do produto das infrações previstas na Convenção ou de bens ${ }^{325}$ cujo valor corresponda ao desse produto, assim como dos bens, equipamentos ou instrumentos utilizados ou destinados a ser utilizados na prática das mesmas infrações (artigo 12, par. $1^{\mathrm{o}}$ e $2^{\circ}$ ).

Nos termos da Convenção de Palermo, o confisco representa a perda dos bens obtidos com a prática delituosa ou dos instrumentos do crime, e a entrega ao Estado-parte dos ativos confiscados deve-se prioritariamente à indenização das vítimas da infração ou à restituição dos bens aos seus legítimos proprietários (artigo 14, par. $2^{\circ}$ ). Para garantir efetiva reparação do dano causado com a prática delituosa, outros bens do investigado, acusado ou condenado podem ser objeto de bloqueio, inclusive os de origem lícita (artigo 12 , par. 3 a 5).

A Convenção das Nações Unidas contra a Corrupção (Decreto n ${ }^{\circ}$ 5687, de 31 de janeiro de 2006) reservou o capítulo VI para regular a chamada "recuperação de ativos". O termo "recuperação de ativos" 326 é empregado na Convenção para designar tanto as

como "preventiva" uma medida (confisco) que, por si, pressupõe a privação definitiva do bem, acreditamos ter sido essa a intenção quando se disse "apreensão preventiva ou confisco (....), com o objetivo de seu eventual confisco". A primeira palavra confisco, empregada logo após "apreensão preventiva", indica a constrição cautelar de bens - ou seja, o bloqueio - para assegurar futuro e "eventual confisco", ou seja, a perda definitiva dos produtos ou instrumentos do crime.

${ }^{323}$ Para os fins da Convenção, o "confisco" de bens deve ser entendido como "a privação com caráter definitivo de bens, por decisão de um tribunal ou outra autoridade competente" (artigo $2^{\circ}$, "g").

${ }^{324}$ Para os fins da Convenção, "bloqueio" é a "proibição temporária de transferir, converter, dispor ou movimentar bens, ou a custódia, ou o controle temporário de bens, por decisão de um tribunal ou de outra autoridade competente" (artigo $2^{\circ}$, “f”). No sentido de cumprir medidas cautelares patrimoniais em cooperação jurídica internacional, estabelece a Convenção que o Estado-parte requerido deverá tomar as medidas cabíveis para identificar, localizar, embargar ou apreender o produto do crime, os bens, os equipamentos ou outros instrumentos do crime, "com vista a um eventual confisco que venha a ser ordenado", seja pelo Estado-Parte requerente, seja pelo Estado-parte requerido a pedido daquele (artigo 13, par. $2^{\circ}$ ).

${ }^{325} \mathrm{O}$ tratado considera como bens "os ativos de qualquer tipo, corpóreos ou incorpóreos, móveis ou imóveis, tangíveis ou intangíveis, e os documentos ou instrumentos jurídicos que atestem a propriedade ou outros direitos sobre referidos ativos" (artigo $2^{\circ}$, “d").

${ }^{326} \mathrm{O}$ termo "recuperação de ativos" é empregado na tradução para a língua portuguesa da Convenção das Nações Unidas contra a Corrupção (Decreto n. 5.687, de 31 de janeiro de 2006). Referida expressão também é utilizada costumeiramente na doutrina para indicar as medidas cautelares patrimoniais e a perda final dos proventos e instrumentos do crime em cooperação jurídica internacional, a exemplo de GIMENES, Marta Cristina Cury Saad. Propostas para a recuperação de ativos. Revista Getúlio, p. 44, set. 2008; MACHADO, Maíra Rocha; REFINETTI, Domingos Fernando (Orgs.). Lavagem de dinheiro e recuperação de ativos: Brasil, Nigéria, Reino Unido e Suíça. São Paulo: Quartier Latin, 2006; SOUZA, Carolina Yumi de. Os caminhos percorridos no combate ao crime. Revista Getúlio, set. p. 42-43, 2008. 
medidas cautelares patrimoniais - "embargo preventivo"327 -, quanto o perdimento final dos instrumentos do crime e de bens obtidos com o provento da infração - "confisco"328.

Em termos gerais, a Convenção das Nações Unidas contra a Corrupção se assemelha à Convenção de Palermo no que se refere às medidas cautelares patrimoniais. Porém, a Convenção das Nações Unidas contra a Corrupção se destaca ao estabelecer três situações nas quais os Estados-partes devem prestar assistência judicial recíproca para fins de "embargo preventivo": a) em execução de uma ordem emanada por tribunal ou autoridade competente do Estado-parte requerente; b) em cumprimento de solicitação "que constitua fundamento razoável para que o Estado-parte requerido considere que existam razões suficientes para adotar esses medidas e que ulteriormente os bens seriam objeto de uma ordem de confisco" ${ }^{329}$; c) ou na adoção de outras medidas necessárias à preservação dos bens para efeitos de futuro e eventual confisco (artigo 54, par. $2^{\circ}$ ).

Já a Convenção Interamericana sobre Assistência Mútua em Matéria Penal (Decreto $n^{\circ}$ 6340, de 3 de janeiro de 2008) prevê a adoção de "medidas cautelares de bens" e estabelece uma rede de cooperação jurídica mais ágil e direta entre os Estados-partes.

Nos termos do artigo 14, da Convenção Interamericana sobre Assistência Mútua em Matéria Penal, a Autoridade Central $^{330}$ de qualquer um dos Estados-partes poderá comunicar à Autoridade Central de outro Estado-parte a informação que possuir sobre a existência, no território deste último, de receitas, produtos e instrumentos de um delito. Neste caso, "as partes prestar-se-ão assistência mútua, na medida permitida por suas leis, para promover os procedimentos cautelares e as medidas de acautelamento das receitas, produtos ou instrumentos do delito" (artigo 15).

\footnotetext{
327،Aos efeitos da presente Convenção: (...) f) por 'embargo preventivo' ou 'apreensão' se entenderá a proibição temporária de transferir, converter ou trasladar bens, ou de assumir a custódia ou o controle temporário de bens sobre a base de uma ordem de um tribunal ou de outra autoridade competente" (artigo $2^{\circ}$, “f”).

$328 ، \mathrm{~g})$ por 'confisco' se entenderá a provação em caráter definitivo de bens por ordem de um tribunal ou contra a autoridade competente" (artigo $2^{\circ}$, "g").

${ }^{329}$ Neste caso, não há ordem de decretação de medida cautelar emanada por autoridade competente do Estado-parte requerente. Ao invés, o Estado-parte requerente envia uma solicitação às autoridades competentes do Estado-parte requerido, a fim de obter destas uma ordem de embargo preventivo ou confisco, a qual, em caso de concessão, será cumprida (artigo 55, “b”). Assim, transfere-se ao Estado-parte requerido a análise originária da viabilidade da medida cautelar objeto da cooperação jurídica internacional.

330،A autoridade central é um órgão técnico especializado, em regra não-jurisdicional, que se encarrega da interlocução internacional em matéria de cooperação jurídica em matéria civil e penal" (ARAS, Vladimir. O papel da autoridade central nos acordos de cooperação penal internacional, cit., p. 73). No Brasil, cumpre o papel de autoridade central nos pedidos de cooperação jurídica internacional em matéria penal o Departamento de Recuperação de Ativos e Cooperação Jurídica Internacional - DRCI, órgão vinculado ao Ministério da Justiça.
} 
O Protocolo de Assistência Jurídica Mútua em Assuntos Penais - Mercosul (Decreto n. 3.468, de 17 de maio de 2000) também estabelece que a assistência compreenderá "medidas acautelatórias sobre bens". A “cooperação acautelatória"331 dáse por intermédio direto das Autoridades Centrais dos Estados-partes. A Autoridade Central do Estado-parte requerido, ao tomar conhecimento da existência, em seu território, de instrumentos, objeto ou frutos do delito, remeterá a informação recebida a suas autoridades competentes para os efeitos de determinar a adoção das medidas cautelares cabíveis (artigo 22, par. $\left.2^{\mathrm{o}}\right)^{332}$.

No que se refere aos tratados bilaterais dos quais o Brasil é signatário, com exceção do tratado Brasil-França (Decreto n. 3.324, de 30 de dezembro de 1999), todos os demais preveem como objeto de cooperação jurídica o cumprimento de medidas cautelares patrimoniais. O emprego de uma infinidade de terminologias diferentes em referência a medidas cautelares ${ }^{333}$ denuncia a ausência de critério técnico nos instrumentos normativos que permitiram a integração desses tratados ao direito interno brasileiro.

Por fim, o Estatuto de Roma (Decreto n 4. 388/2002) estabelece, em seu art. 93, I, "k", que os Estados-partes, como forma de cooperar com o Tribunal Penal Internacional, devem, quando solicitados, “identificar, congelar ou apreender o produto de crimes, bens, haveres e instrumentos ligados aos crimes, com vistas à sua eventual declaração de perda, sem prejuízo dos direitos de terceiros de boa-fé”,334.

\footnotetext{
${ }^{331}$ Termo empregado no art. 22, par. $1^{\circ}$, do Protocolo de Assistência Jurídica Mútua em Assuntos Penais: “A Autoridade competente do Estado requerido diligenciará a solicitação de cooperação acautelatória, se esta contiver informação suficiente que justifique a procedência da medida solicitada. Esta medida será efetivada de acordo com a lei processual e substantiva do Estado requerido" (destacamos).

${ }^{332} \mathrm{O}$ Protocolo inova em seu artigo 24 ao estabelecer regras de administração dos bens constritos cautelarmente. O Estado-parte requerido que tiver a custódia dos bens bloqueados poderá dispor desses ativos de conformidade com o estabelecido em sua lei interna. Poderá, ainda, na medida em que seu ordenamento interno entender adequado, transferir a outro Estado-parte os próprios bens constritos ou o produto correspondente à sua venda.

${ }^{333}$ Medidas cautelares patrimoniais são indicadas por vários termos diferentes, repetidos muitas vezes em um mesmo diploma e traduzidos - na literalidade - ao português: "sequestro" (Brasil-Cuba, Brasil-Itália, Brasil-Peru, Brasil-Suíça, Brasil-Suriname), "imobilização” (Brasil-China, Brasil-EUA, Brasil-Ucrânia), "bloqueio" (Brasil-China, Brasil-Coreia do Sul, Brasil-Canadá), "congelamento temporário" (Brasil-EUA), "medidas cautelares" (Brasil-Colômbia, Brasil-Peru, Brasil-Suíça, Brasil-Espanha), "indisponibilidade" (Brasil-Peru, Brasil-Suriname), "arresto" (Brasil-Peru), "medidas provisionais" (Brasil-Peru). O tratado Brasil-Portugal prevê "apreensão ou medida similar (...) para prevenir qualquer transação, transmissão ou disposição dos bens que sejam ou possam ser afetados”.

${ }^{334}$ No caso do Estatuto de Roma, quando deslocada ao Tribunal Penal Internacional a competência para investigar, processar e julgar crimes internacionais de violação aos direitos humanos, a atuação desta Corte não prescinde da cooperação judicial com os Estados-partes, seja com o Estado em cujo território ocorreu o fato, seja com o país no qual se encontram testemunhas, vítimas e o próprio acusado. A respeito da cooperação jurídica internacional vertical, v. VERGUEIRO, Luiz Fabricio Thaumaturgo. Implementação da cooperação jurídica internacional vertical, cit.
} 
Portanto, os acordos internacionais de assistência jurídica em matéria penal celebrados pelo Brasil garantem a adoção de medidas cautelares pelo Estado requerido, para garantir utilidade e eficácia, quer do futuro confisco de produtos e instrumentos do crime, quer da reparação do dano causado pelo delito ${ }^{335}$, como efeito automático de sentença penal condenatória proferida por autoridade judicial do Estado requerente ${ }^{336}$.

Importante não passar incólume que os tratados analisados externam de alguma forma uma visão bilateral da cooperação jurídica internacional, ou seja, como matéria de interesse apenas dos Estados-partes e afeta ao Direito Internacional. O alcance da visão bilateral nos tratados reflete a pouca menção a direitos fundamentais específicos como motivos para denegação da assistência, direitos esses que teriam o condão de assegurar, também, a participação ativa e efetiva da pessoa atingida.

Os tratados analisados ocupam-se de resguardar o interesse do terceiro de boafé, mas apenas o tratado Brasil-Peru ${ }^{337}$ prevê expressamente que o pedido de auxílio mútuo deva ser executado, "em particular, com observância dos direitos de qualquer pessoa que possa ser atingida pela execução da medida". Somente os tratados Brasil-Portugal $^{338}$ e BrasilSuíça ${ }^{339}$ pugnam pela denegação da assistência, se o Estado requerido considerar que o atendimento do pedido violaria os direitos e liberdades fundamentais da pessoa humana.

Outrossim, em caráter igualmente excepcional, o tratado Brasil-Canadá garante especificamente a participação, nos procedimentos do Estado requerido, das autoridades

\footnotetext{
${ }^{335}$ FÁBIO RAMAZZINI BECHARA e MARCILÂNDIA ARAÚJO defendem que medidas cautelares patrimoniais cumpridas por assistência jurídica internacional teriam outras duas finalidades, além daquelas já citadas: evitar o enriquecimento sem causa, ou, ainda, evitar o cometimento de crimes (Medidas de cooperação reais, cit., p. 491).

${ }^{336}$ Ressalte-se, entretanto, a ênfase dada mais ao confisco dos produtos e instrumentos do crime que à reparação do dano causado pelo delito. Até porque os crimes transnacionais, em sua maioria, não permitem o reconhecimento de uma vítima específica.

${ }^{337}$ Decreto n. 3.988 , de 29 de outubro de 2001.

${ }^{338}$ A redação da cláusula do tratado é a seguinte: “Art. $3^{\circ}$ - Recusa de Auxílio - 1. O auxílio será recusado se a Parte considerar que: (...) d) o cumprimento do pedido ofende os direitos fundamentais da pessoa humana". Como aponta DENISE NEVES ABADE, "a história ditatorial dos dois países é a resposta provável para a existência deste dispositivo, que, contudo, nunca foi invocado desde 1994, data da incorporação final do tratado na ordem pública brasileira" (Direitos fundamentais na cooperação jurídica internacional: extradição, assistência jurídica, execução de sentença estrangeira e transferência de presos, cit., p. 327).

339“1. A cooperação jurídica poderá ser recusada: (...) f) se existirem razões sérias para acreditar que o procedimento penal contra a pessoa processada não respeita as garantias estipuladas nos instrumentos internacionais de proteção aos direitos humanos, particularmente no Pacto Internacional relativo aos Direitos Civis e Políticos, de 16 de dezembro de 1966”. A respeito da relação entre Brasil e Suíça para o auxílio mútuo em matéria penal, v. MARQUES, Silvio Antônio. Cooperação jurídica com a Suíça. In: BALTAZAR JÚNIOR, Paulo José; LIMA, Luciano Flores de (Orgs.). Cooperação jurídica internacional em matéria penal. Porto Alegre: Verbo Jurídico, 2010. p. 295-320.
} 
públicas do Estado requerente e de "outras pessoas envolvidas na investigação ou no processo", o que inclui a pessoa atingida.

Nos demais acordos internacionais de assistência jurídica em matéria penal celebrados pelo Brasil, entretanto, a pessoa atingida parece ter sido apartada, deslocada e esquecida do processo de cooperação jurídica internacional.

Os acordos internacionais firmados pelo Brasil fixam várias hipóteses de denegação válida da assistência requerida, resumidas nas seguintes categorias: a) crime político ou crime militar; b) ameaça à ordem pública, soberania, segurança e outros interesses essenciais; c) medida contrária ao ordenamento jurídico ou se a obrigação objetivada no pedido de cooperação for ilícita para o Estado requerido; d) discriminação odiosa; e) ofensa a direitos fundamentais ${ }^{340}$.

São hipóteses de denegação que, mesmo indiretamente, representam um rol de justificativas passíveis de serem invocadas à proteção dos direitos fundamentais da pessoa atingida $^{341}$, compromisso, aliás, assumido em inúmeros acordos internacionais de natureza humanitária. Desde que com a devida ponderação, para não implicar um engessamento ineficiente, qualquer modalidade de cooperação jurídica deve encontrar limite nos direitos fundamentais básicos da pessoa atingida, estejam ou não comtemplados em tratado.

\subsection{Cooperação jurídica no Brasil}

A Constituição Federal brasileira de 1988 tratou muito genericamente da cooperação jurídica internacional. Em seu artigo $4^{\circ}$, inciso IX, reconhece, dentre os princípios a reger as relações internacionais do Brasil ${ }^{342}$, a "cooperação entre os povos para o progresso da humanidade".

No âmbito da integração regional com os países latino-americanos, previu o Constituinte originário que o Brasil "buscará a integração econômica, política, social e cultural dos povos da América do Latina, visando à formação de uma comunidade latinoamericana de nações". Apesar da boa intenção, o objetivo de se buscar maior “integração

\footnotetext{
${ }^{340}$ ABADE, Denise Neves. Direitos fundamentais na cooperação jurídica internacional: extradição, assistência jurídica, execução de sentença estrangeira e transferência de presos, cit., p. 240.

${ }^{341}$ ABADE, Denise Neves. Direitos fundamentais na cooperação jurídica internacional: extradição, assistência jurídica, execução de sentença estrangeira e transferência de presos, cit., p. 242.

${ }^{342}$ Dentre os quais, destacam-se ainda a "prevalência dos direitos humanos" e a "igualdade entre os Estados" (incisos II e V, do art. $4^{\circ}$, da CF).
} 
latino-americana" parece não ter fugido da mera retórica, porquanto a jurisprudência das cortes superiores no Brasil não vê neste dispositivo fundamental justificativa para abordar a cooperação com os Estados latino-americanos distintamente como tem tratado com os demais países, inclusive na seara penal ${ }^{343}$.

Cumpre registrar que o Mercosul, instituído por um dos principais acordos de integração regional entre países sul-americanos, é entidade intergovernamental. Rejeitouse a ideia de criar um direito comunitário no âmbito do Mercosul e de estabelecer um tribunal supranacional, modelo adotado hoje na União Europeia, que propicia novos e mais ágeis mecanismos de cooperação ${ }^{344}$.

A Constituição Federal menciona alguns instrumentos de cooperação jurídica internacional. Dispõe o artigo 105, I, "i”, que compete ao Superior Tribunal de Justiça "a homologação de sentenças estrangeiras e a concessão de exequatur às cartas rogatórias”. A competência do Superior Tribunal de Justiça para conceder exequatur e homologar sentença estrangeira - que, antes, competia ao Supremo Tribunal Federal - decorre da recente Emenda Constitucional 45 de 2005. Ao Supremo Tribunal Federal, ficou reservada a competência para julgar pedidos de extradição (artigo 102, I, “g”).

Também é matéria constitucional a competência prevista à Justiça Federal para julgar "as causas fundadas em tratado ou contrato da União com Estado estrangeiro ou organismo internacional", conforme determina o artigo 109, III. Este dispositivo possibilita aos juízes federais de primeira instância processar e julgar os pedidos de auxílio direto, modalidade de cooperação jurídica que será estudada no item 3.2.2.2 deste capítulo.

Se na esfera constitucional a cooperação jurídica internacional é tratada muito genericamente, na esfera infraconstitucional, o regramento é desuniforme, já que não existe uma lei geral da cooperação no Brasil, a exemplo de outros países.

\footnotetext{
${ }^{343}$ ABADE, Denise Neves. Direitos fundamentais na cooperação jurídica internacional: extradição, assistência jurídica, execução de sentença estrangeira e transferência de presos, cit., p. 225.

344 “O Mercosul é uma entidade intergovermamental dotada de personalidade jurídica. O Tratado de Assunção criou uma entidade intergovernamental, na qual os Estados integrantes, a partir de um princípio de igualdade e norteados pela fórmula do consenso, dispõem e decidem acerca das distintas matérias comtempladas no Tratado. Opção, portanto, intergovernamental e não supranacional”. Desta forma, "com a atual conformação do Mercosul não são incidentes os princípios denominados de aplicação direta (ou efeito direto) e o princípio da primazia das normas processuais de fonte supranacional ou internacional sobre a de fonte interna, diferentemente do que ocorre no marco legal comunitário europeu" (CERVINI, Raul; TAVARES, Juarez. Princípios da cooperação judicial penal internacional no Protocolo do Mercosul, cit., p. 26). No mesmo sentido: "O Mercosul, nos limites em que se apresenta hoje, não traz traço de supranacionalidade e tampouco tem demonstrado concretamente a intenção de atingi-la" (SOUZA, Solange Mendes de. Cooperação jurídica penal no Mercosul: novas possibilidades, cit., p. 42).
} 
A tramitação dos pedidos de cooperação submete-se a emaranhado de normas dispersas: passa por três códigos diferentes (Lei de Introdução às Normas do Direito Brasileiro, Código de Processo Civil e Código de Processo Penal), por Regimentos internos (Resolução n. 9 e Regimento Interno do Superior Tribunal de Justiça, bem como o Regimento Interno do Supremo Tribunal Federal) e diversas portarias, além de uma infinidade de tratados multilaterais e bilaterais firmados pelo Brasil ${ }^{345}$.

$\mathrm{Na}$ cooperação jurídica internacional em matéria penal, em especial, quanto aos instrumentos usados para cumprimento extraterritorial de medidas cautelares patrimoniais - carta rogatória e auxílio direto, o Código de Processo Penal possui alguns dispositivos sobre a carta rogatória (artigos 780 a 790). Algumas legislações esparsas também tratam da cooperação internacional penal, como a Lei de Proteção Ambiental (Lei n. 9.605/98, artigos 77 e 78) e a Lei de Lavagem de Dinheiro (Lei n. 9.612/98, artigo $8^{\circ}$ ). No mais, aplica-se subsidiariamente o Código de Processo Civil, que estabelece, em seu artigo 202, linhas gerais para o processamento da carta rogatória.

Ademais, imperioso mencionar a Resolução n. 9/2005, editada pelo Superior Tribunal de Justiça para disciplinar especificamente o trâmite, naquele tribunal, das cartas rogatórias e da homologação de sentença estrangeira. Através da Resolução n. 9/2005, o STJ tentou amenizar as críticas que se fazia à jurisprudência do Supremo Tribunal Federal ao tema da cooperação jurídica ao permitir, v. g., o cumprimento de carta rogatória cujo objeto tenha caráter executório ${ }^{346}$.

A ausência de uma regulamentação uniforme, centralizada e coerente sobre a cooperação jurídica no Brasil dificulta o cumprimento dos pedidos pelos aplicadores do direito. Por isso, a jurisprudência do Supremo Tribunal Federal e do Superior Tribunal de Justiça tenta suprir essa lacuna legislativa, muitas vezes com decisões conflitantes, aumentando a carga de insegurança jurídica.

Nos últimos anos, com o avanço significativo do número de causas criminais que envolvem assistência jurídica em matéria penal, é possível verificar um esforço para se estabelecer uma lei geral da cooperação.

\footnotetext{
${ }^{345}$ Para atender ao propósito da dissertação, interessam-nos mais os tratados multilaterais e bilaterais que versam sobre medidas cautelares patrimoniais em cooperação jurídica internacional, os quais já estão discriminados em nota de rodapé ao item 3.1, deste mesmo capítulo III.

${ }^{346}$ Trataremos ao longo deste capítulo a respeito das cartas rogatórias de caráter executório.
} 
Nesse sentido, tramita no Congresso o Projeto de Lei n. 326/2007. Trata-se de Projeto de Lei de iniciativa do Senado que busca regulamentar a "assistência judiciária internacional" em matéria penal nos casos de investigação, instrução processual e julgamento de delitos, além de estabelecer mecanismo de prevenção e bloqueio de operações suspeitas de lavagem de dinheiro. De acordo com a redação original do projeto $^{347}$, prevalecerão as normas dos tratados internacionais de cooperação em matéria penal, regendo o trâmite do pedido de assistência. A lei a que se refere o projeto será aplicada na ausência de tratado, circunstância na qual o Brasil prestará a medida mediante compromisso de reciprocidade formalizado pelo Estado requerente.

Importante destacar a existência do anteprojeto de lei geral de cooperação jurídica internacional de iniciativa de grupo de especialistas designados pelo Ministério da Justiça $^{348}$. Acrescenta-se, ainda, estudo importante realizado pelo Instituto Ibero-americano de Direito Processual, resultando em um código modelo de cooperação interjurisdicional para iberoamérica $^{349}$.

Como bem observa Denise Neves Abade, o Projeto de Lei n. 326/2007, os diferentes anteprojetos e até o código modelo para a iberoamérica teriam em comum dois efeitos significativos sobre a cooperação jurídica internacional em matéria penal: primeiro, unificariam a visão brasileira sobre o tema, superando o império da fragmentada e muitas vezes equívoca interpretação jurisprudencial; segundo, dariam norte a tomadas de decisão pelos negociadores de futuros tratados, para que diplomas internacionais firmados pelo Brasil, na medida do possível, tivessem um mínimo de identidade e homogeneidade ${ }^{350} 351$.

\footnotetext{
${ }^{347}$ O Senador Romeu Tuma apresentou proposta de emenda com profunda alteração ao projeto, o que foi aprovado pela comissão de Direitos Humanos e Legislação Participativa do Senado em 2012. No mesmo ano, o projeto foi retirado de pauta a pedido do relator, Senador Paulo Davim, para reexame. Informação disponível no site do SENADO FEDERAL. Disponível em: <www.senado.gov>. Acesso em: 14 jul. 2013.

${ }^{348}$ Comissão instituída pela Portaria n. 2.199, de 10 de agosto de 2004. O texto completo da portaria pode ser encontrado no site da ADVOCACIA-GERAL DA UNIÃO. Disponível em: <www.agu.gov.br>. Acesso em: 14 jul. 2013.

${ }^{349}$ Versão em português do código modelo de cooperação interjurisdicional para iberoamérica pode ser consultado no site www.direitoprocessual.org.br (acessado em 14.07.13).

${ }^{350}$ ABADE, Denise Neves. Direitos fundamentais na cooperação jurídica internacional: extradição, assistência jurídica, execução de sentença estrangeira e transferência de presos, cit., p. 233.

${ }^{351}$ Com efeito, os tratados bilaterais firmados pelo Brasil, a depender da exigência da outra parte, são, em muitos aspectos, diferentes e contraditórios entre si. A título de exemplo, o tratado Brasil-EUA impede o cumprimento de medidas em assistência mútua no interesse da defesa, ao passo que o tratado Brasil-Peru exige, como requisito instransponível, a observância dos direitos fundamentais da pessoa atingida. Em outro aspecto, a maioria exige dupla incriminação, mas há tratados que dispensam a dupla incriminação a quaisquer medidas, não importando o grau de intromissão (Brasil-EUA e Brasil-Ucrânia); já outros exigem dupla incriminação somente às medidas cautelares patrimoniais (Brasil-Itália e Brasil-Peru).
} 
Por fim, o Departamento de Recuperação de Ativos e Cooperação Jurídica Internacional - DRCI, que é vinculado ao Ministério da Justiça, atua como Autoridade Central brasileira.

As chamadas Autoridades Centrais são atores essenciais na cooperação jurídica internacional $^{352}$. Em geral, trata-se de órgão especializado, em regra não-jurisdicional, que se encarrega da interlocução internacional na cooperação jurídica em matérias civil e penal $^{353}$. O modelo de cooperação por Autoridades Centrais surgiu pioneiramente pela Conferência de Haia para o Direito Internacional Privado, tendo sido adotado depois em vários tratados em matéria civil. Dada a eficiência que mostrou, o mesmo modelo passou a ser incorporado também aos vários tratados multi e bilaterais em matéria penal ${ }^{354}$, inclusive aqueles firmados pelo Brasil.

No âmbito brasileiro, o DRCI foi criado por meio do Decreto n. 4.991, de 18 de fevereiro de 2004, recebendo a incumbência de facilitar e coordenar a cooperação internacional, de estabelecer canais de comunicação com os Estados requeridos e legalizar o processo de cooperação ${ }^{355}$. A recuperação de ativos é sua meta principal $^{356}$.

\subsubsection{Limites}

Inúmeros preceitos foram estabelecidos no Direito Internacional e incorporados pelos tratados bilaterais e multilaterais. Esses preceitos de direito internacional postam-se como limites à atuação do Estado na cooperação jurídica internacional. Trata-se de questões que podem ser invocadas como fatores limitantes à prestação da cooperação jurídica internacional $^{357}$.

\footnotetext{
${ }^{352}$ VERGUEIRO, Luiz Fabricio Thaumaturgo. Apontamentos gerais sobre a cooperação jurídica internacional e suas modalidades, cit., p. 357.

${ }^{353}$ ARAS, Vladmir. O papel da autoridade central nos acordos de cooperação penal internacional, cit., p. 73.

354 "A criação de um sistema de comunicação baseado em autoridades centrais com esta função, incrementando a cooperação administrativa entre os Estados, é uma das realizações de sucesso da Conferência de Haia" (ARAÚJO, Nádia de (Coord.). Cooperação jurídica internacional no Superior Tribunal de Justiça: comentários à Resolução n ${ }^{\circ}$ 9/2005, cit., p. 4).

${ }^{355}$ CORDANI, Dora Cavalcanti. A cooperação jurídica Internacional em matéria penal no Brasil: as cartas rogatórias e o auxílio direto - controle dos atos pela parte atingida, cit., p. 104.

${ }^{356}$ SOUZA, Carolina Yumi de. Os caminhos percorridos no combate ao crime, cit., p. 42.

${ }^{357} \mathrm{O}$ enquadramento normativo dos institutos tradicionais de cooperação internacional em matéria penal partem do paradigma de que existem Estados Nacionais, com soberania e interesses próprios, aptos a cooperar na exata medida de seus interesses. Portanto, os limites à cooperação jurídica internacional, como, por exemplo, a exigência de dupla incriminação, é fruto do desconhecimento e da desconfiança do modelo adotado no Estado requerente. Nesta linha de pensamento, como observa DENISE ABADE, "o modo de proteção de direitos fundamentais do Estado Requerido é aquele que deve ser levado em consideração, pois
} 
Importa à dissertação tratar dos limites - materiais ${ }^{358}$ - da cooperação jurídica internacional, dentre os quais destacamos: o respeito à ordem pública, a exigência de dupla incriminação, a proibição do ne bis in idem e o locus regit actum.

\subsubsection{Respeito à ordem pública}

Infere-se a concepção de ordem pública do artigo 17, da Lei de Introdução às Normas do Direito Brasileiro, que estabelece: “As leis, atos e sentenças estrangeiras, bem como quaisquer outras declarações de vontade, não terão eficácia no Brasil quando ofenderem a soberania nacional, a ordem pública e os bons costumes”. Em questões relativas ao direito processual, conforme previsto no artigo 17, da mesma lei: "a prova dos fatos ocorridos em país estrangeiro rege-se pela lei que nele vigorar, quanto ao ônus e aos meios de produzir-se, não admitindo os tribunais provas que a lei brasileira desconheça”.

A ordem pública também é tratada na Resolução n. 9, do Superior Tribunal de Justiça: "Não será homologada sentença estrangeira ou concedido exequatur a carta rogatória que ofenda a soberania ou a ordem pública" (artigo $6^{\circ}$ ).

Ademais, os tratados internacionais falam em algum momento da ordem pública como limite à assistência pelos Estados-partes, mas sem defini-la ${ }^{359}$.

Entretanto, nenhuma norma de direito interno delimita o conceito de ordem pública, nem existe convenção internacional que o defina ${ }^{360}$, por isso "ordem pública" é expressão fluida e de difícil precisão. A compreensão do que pode se considerar como ordem pública traz dificuldades ainda não superadas pela doutrina ${ }^{361}$.

não há outra garantia equivalente que o Estado requerente possa apresentar" (Direitos fundamentais na cooperação jurídica internacional: extradição, assistência jurídica, execução de sentença estrangeira e transferência de presos, cit., p. 189).

${ }^{358}$ Entendermos que seria despiciendo falar sobre os limites formais da cooperação, que decorrem de formalidades exigidas em tratados, normas regimentais internas e portarias (pedido por escrito, tradução para a língua do Estado requerido, autenticação ou legalização, dados necessários, dentre outros requisitos). Sobre os limites formais à cooperação, v. WEBER, Patrícia Nuñez. A cooperação jurídica internacional em medidas processuais penais. Porto Alegre: Verbo Jurídico, 2011. p. 119, p. 88-90.

${ }^{359}$ A expressão mais usada nos tratados internacionais firmados pelo Brasil, seja no plano multilateral seja no plano bilateral, é que de que a cooperação judiciária poderá ser recusada "Se o Estado Parte requerido considerar que a execução do pedido pode afetar sua soberania, sua segurança, sua ordem pública ou outros interesses essenciais".

${ }^{360}$ CERVINI, Raul; TAVARES, Juarez. Princípios da cooperação judicial penal internacional no Protocolo do Mercosul, cit., p. 121.

${ }^{361}$ SOUZA, Solange Mendes de. Cooperação jurídica penal no Mercosul: novas possibilidades, cit., p. 68. 
Em termos gerais, o respeito à ordem pública é um dos princípios basilares de direito internacional e excepciona a obrigação de cooperar com os demais Estados, quer em cumprimento de tratados internacionais, quer mediante promessa de reciprocidade.

No entendimento de Raúl CERvini e JuARez TAVARes, na acepção de ordem pública estariam reunidos os interesses essenciais e os de política interna nos quais o Estado assenta sua individualidade jurídica. Trata-se, pois, do "conjunto de valorações de caráter político, social, econômico ou moral, próprias de uma comunidade determinada, que definem sua fisionomia em um dado momento histórico também determinado. Essas valorações fundamentam o direito positivo que a ordem pública procura tutelar"362.

Para NÁdiA DE ARAÚJO, ordem pública exprime o sentido principiológico pretendido por determinada ordem jurídica, o que não se restringe ao mero conjunto de leis existentes no país. Na cooperação jurídica internacional em matéria penal, a ordem pública incidiria em dois níveis. O primeiro nível diz respeito às normas e princípios cogentes no ordenamento nacional, "que, por força do princípio da imperatividade, não podem ser afastados pela vontade das partes". O segundo nível é de caráter universal e representa o "respeito pela ordem pública de outros povos pelo reconhecimento de direitos, padrões de moralidade, de equidade, de igualdade e de segurança adquiridos entre os Estados" 363 .

Em semelhante sentido, LuIz FABRício VergueIro distingue ordem pública interna de ordem pública internacional. A acepção da ordem pública internacional, observa VERGUEIRO, "tem importantes reflexos para o tema da cooperação jurídica internacional, eis que servirá de parâmetro para aferição da possibilidade de atendimento a solicitação de autoridade estrangeira, seja para medidas 'simples' de natureza instrumental, ou mesmo para medidas mais gravosas que atinjam o patrimônio ou a liberdade das pessoas"364.

Considerados tanto o aspecto interno quanto o internacional, normas de proteção às garantias individuais da pessoa humana - que é o destinatário de todas as

\footnotetext{
${ }^{362}$ CERVINI, Raul; TAVARES, Juarez. Princípios da cooperação judicial penal internacional no Protocolo do Mercosul, cit., p. 120-121.

${ }^{363}$ ARAÚJO, Nádia de (Coord.). Cooperação jurídica internacional no Superior Tribunal de Justiça: comentários à Resolução $n^{\circ}$ 9/2005, cit., p. 68-69. A autora também cita um terceiro nível relativo ao impedimento à aplicação de leis estrangeiras indicadas pelas regras de conexão do DIP - direito internacional privado, o que não abrange a cooperação jurídica internacional em matéria penal.

${ }^{364}$ VERGUEIRO, Luiz Fabricio Thaumaturgo. Apontamentos gerais sobre a cooperação jurídica internacional e suas modalidades, cit., p. 395.
} 
normas jurídicas ${ }^{365}$ - podem ser consideradas como normas de ordem pública, porque, em comum, são construídas de princípios indispensáveis para a organização da vida social ${ }^{366}$.

Significa que há clara relação de interdependência entre a ordem pública nacional e a internacional na promoção dos direitos humanos ${ }^{367}$. Nesse compasso, defende LUIZ FABRÍ́cIO VERGUEIRO:

“(..) mais modernamente, pode-se dizer que um dos elementos essenciais para aferição de eventual ofensa à ordem pública reside no respeito aos Direitos Humanos, sendo este certamente, na seara penal, o principal elemento de conexão a ser observado no momento de efetivar-se o reconhecimento, ou repúdio, a determinado pedido de cooperação jurídica internacional. ${ }^{368}$

O conceito de ordem pública, portanto, congrega os valores fundamentais de uma determinada sociedade, funcionando como barreira protetora contra atos, nacionais ou estrangeiros, que ofendam de forma grave e manifesta o seu arcabouço normativo fundamental $^{369}$. Por isso, não pode ser considerada violação à ordem pública nacional, a título de exemplo, a simples diversidade de sistemas processuais nem tampouco o fato de o pedido de assistência ter caráter executório ${ }^{370}$.

\footnotetext{
${ }^{365 ، U m ~ c o n c e i t o ~ d e ~ o r d e m ~ p u ́ b l i c a ~ s o ́ ~ p o d e r i a ~ s e r ~ a l c a n c ̧ a d o, ~ n a ̃ o ~ e m ~ a t e n c ̧ a ̃ o ~ a o s ~ i n t e r e s s e s ~ d o s ~ d i v e r s o s ~}$ Estados, mas, sobretudo, pela ótica dos direitos humanos, corolários que são da dignidade da pessoa humana, que é o destinatário final de todas as normas jurídicas" (ARAÚJO, Nádia de (Coord.). Cooperação jurídica internacional no Superior Tribunal de Justiça: comentários à Resolução no 9/2005, cit., p. 69).

${ }^{366}$ ARAÚJO, Nádia de (Coord.). Cooperação jurídica internacional no Superior Tribunal de Justiça: comentários à Resolução no 9/2005, cit., p. 69.

${ }^{367}$ BECHARA, Fábio Ramazzini. Cooperação jurídica internacional em matéria penal: eficácia da prova produzida no exterior, cit., p. 123.

${ }^{368}$ VERGUEIRO, Luiz Fabricio Thaumaturgo. Apontamentos gerais sobre a cooperação jurídica internacional e suas modalidades, cit., p. 396. DENISE NEVES ABADE, semelhantemente, afirma que a teoria da ordem pública é - ou deveria ser - a porta de entrada mais frequente dos direitos fundamentais nos tratados de assistência internacional (Direitos fundamentais na cooperação jurídica internacional: extradição, assistência jurídica, execução de sentença estrangeira e transferência de presos, cit., p. 327). Também defende SÉRGIO MORO que, na cooperação jurídica em matéria penal, para dar maior precisão aos conceitos de "ordem pública" e "bons costumes", é mais apropriado identificá-los com a necessidade de resguardo do cerne dos direitos fundamentais do acusado ou investigado. E conclui: "a extradição e igualmente a cooperação internacional em matéria penal relativamente a outras medidas, de cunho coercitivo ou não, podem ser denegadas se estiverem em risco os direitos fundamentais básicos do acusado ou investigado, ou, para utilizar a expressão da Corte Europeia de Direitos Humanos, quando for constatada um 'denegação flagrante de Justiça' pelo País Requerente" (Cooperação jurídica internacional em casos criminais: considerações gerais, cit., p. 43).

${ }^{369}$ WEBER, Patrícia Nuñez. A cooperação jurídica internacional em medidas processuais penais, cit., p. 93.

${ }^{370}$ BECHARA, Fábio Ramazzini. Cooperação jurídica internacional em matéria penal: eficácia da prova produzida no exterior, cit., p. 123.
} 


\subsubsection{Exigência de dupla incriminação}

Os tratados internacionais firmados pelo Brasil exigem, em geral, a chamada dupla incriminação ou tipificação: os fatos descritos no pedido de assistência jurídica devem ser considerados criminosos na jurisdição de ambos os Estados, requerente e requerido. Exige-se, deste modo, identidade-modelo de um crime hipotético ${ }^{371}$, uma vez que os fatos que ensejam o pedido de assistência jurídica internacional, além de típicos, antijurídicos e puníveis no Estado requerente, também devem ser no Estado requerido.

Em matéria de extradição, a regra da dupla incriminação é recorrente nos diplomas internacionais. Sob o ponto de vista do interesse do Estado, a inclusão da dupla incriminação nos tratados relativos à extradição se justifica pelo fato de o Estado requerido não dispensar tempo, recursos nem o uso da força coercitiva para auxiliar a persecução penal de condutas que, consideradas penalmente irrelevantes, sequer são tipificadas em sua ordem interna. Por outro lado, sob o ponto de vista dos direitos dos indivíduos, a exigência da dupla incriminação dá maior segurança jurídica aos pedidos de extradição, em respeito à dignidade humana, sobretudo ao princípio da nulla poena sine praevia lege $e^{372}$.

$\mathrm{Na}$ assistência jurídica internacional, a regra da dupla incriminação varia de acordo com o tratado e depende da medida solicitada. Mas, de uma maneira geral, pode-se identificar a tendência de se destinar a dupla incriminação às medidas que deem maior grau de intromissão nos direitos fundamentais da pessoa atingida ${ }^{373}$.

Assim, quanto aos tratados firmados pelo Brasil sobre assistência jurídica em matéria penal, é possível dividi-los em três grandes grupos: a) tratados que exigem a dupla incriminação a quaisquer medidas; a) tratados que dispensam por completo a dupla incriminação; c) tratados que dispensam a dupla incriminação, salvo paras medidas que

\footnotetext{
${ }^{371}$ ABADE, Denise Neves. Direitos fundamentais na cooperação jurídica internacional: extradição, assistência jurídica, execução de sentença estrangeira e transferência de presos, cit., p. 254,

${ }^{372}$ ABADE, Denise Neves. Direitos fundamentais na cooperação jurídica internacional: extradição, assistência jurídica, execução de sentença estrangeira e transferência de presos, cit., p. 265-266.

${ }^{373} \mathrm{Na}$ lição de RAÚl CERVINI e JUAREZ TAVARES, todo pedido de cooperação jurídica internacional traz, direta ou indiretamente, alguma intromissão de ordem jurídica de um Estado (requerente) a outro (requerido). Essa intromissão afeta direitos patrimoniais e pessoais. Assim, é possível estabelecer "níveis" de cooperação jurídica internacional em matéria penal: o primeiro nível compreenderia "as medidas de assistência leve e simples" (notificações e obtenção de provas); o segundo nível englobaria as medidas "suscetíveis de causar gravame irreparável aos bens das pessoas" (medidas assecuratórias reais, como sequestro e busca e apreensão); e no terceiro nível estariam os pedidos de cooperação "suscetíveis de causar gravame irreparável aos direitos e liberdades" (extradição) (Princípios da cooperação judicial penal internacional no Protocolo do Mercosul, cit., p. 66). No mesmo sentido: MORO, Sérgio Fernando. Cooperação jurídica internacional em casos criminais: considerações gerais, cit., p. 18.
} 
causem constrição a garantias individuais, como medidas cautelares patrimoniais e meios de obtenção de prova (busca e apreensão, quebra de sigilo e interceptação telefônica).

Nos tratados multilaterais, a Convenção Interamericana sobre Assistência Mútua em Matéria Penal prevê que o pedido de assistência jurídica pode ser negado pelo Estado requerido por ausência de dupla incriminação somente quando o pedido referir-se às medidas de embargo e sequestro de bens, inspeção e confisco incluindo buscas domiciliares (artigo $5^{\circ}$ ). Para os demais casos, a assistência deve ser prestada, mesmo que o fato dê origem a medida não punível segundo a legislação do Estado requerido.

No mesmo sentido, dispõe o Protocolo de Assistência Mútua em Assuntos Penais - Mercosul, em seu artigo $1^{\circ}$, inc. $4^{\circ}$, que a assistência será prestada mesmo quando as condutas não constituam delitos no Estado requerido, sem prejuízo do previsto nos artigos 22 (medidas cautelares) e 23 (entrega de documentos). Importante ressaltar que as medidas previstas nos artigos 22 e 23 devem ser efetivadas, segundo o Protocolo, "de acordo com a lei processual e substantiva do Estado requerido".

No âmbito bilateral, dispensam dupla incriminação os tratados Brasil-EUA ${ }^{374}$, Brasil-Ucrânia $^{375}$; Brasil-Canadá ${ }^{376}$, Brasil-Suriname ${ }^{377}$; Brasil Espanha ${ }^{378}$.

Embora o MLAT Brasil-EUA dispense a dupla incriminação para quaisquer pedidos de assistência mútua, o sistema jurídico estadunidense o exige para a obtenção de medidas cautelares patrimoniais. Infrações fiscais e prática de evasão de divisas não constituem delitos nos EUA. Portanto, pedidos de assistência para bloqueio de bens em referibilidade a um desses crimes poderão ser negados pela autoridade central dos EUA, por violação da ordem pública interna ${ }^{379}$.

\footnotetext{
374، A assistência será prestada ainda que o fato sujeito a investigação, inquérito ou ação penal não seja punível na legislação de ambos os Estados" (artigo $1^{\circ}$, inc. $3^{\circ}$, Decreto n. 3820, de 2 de maio de 2001).

375، “A assistência será prestada ainda que o fato sujeito a investigação, inquérito ou ação penal não seja punível na legislação de ambas as partes" (artigo $1^{\circ}$, inc. $3^{\circ}$, Decreto n. 5984, de 12 de dezembro de 2006).

376، "Para os fins do parágrafo 1 deste artigo, matéria penal refere-se a investigações ou processos judiciais relativos a qualquer crime previsto por uma lei de um dos Estados Contratantes." (artigo $1^{\circ}$, inc. $3^{\circ}$, Decreto n. 6.747, de 22 de janeiro de 2009).

377. A assistência será prestada ainda que a conduta sujeita a investigação, inquérito ou ação penal não seja punível nos termos da legislação de ambas as Partes." (artigo $1^{\circ}$, inc. $4^{\circ}$, Decreto n. 6.832, de 29 de abril de 2009).

378، "O auxílio será prestado mesmo que o fato pelo qual se processa na Parte requerente não seja considerado delito pelo ordenamento jurídico da Parte requerida." (artigo $2^{\circ}$, Decreto n. 6.681, de 8 de dezembro de 2008).

${ }^{379}$ Cf. MANUAL de cooperação jurídica internacional e recuperação de ativos: cooperação em matéria penal. Brasília: Ministério da Justiça, 2008. p. 133.
} 
Exigem a presença de dupla incriminação os tratados Brasil-Cuba ${ }^{380}$, BrasilFrança $^{381}$; Brasil-Portugal ${ }^{382}$, Brasil-Coreia ${ }^{383}$ e Brasil-Suíça ${ }^{384}$.

O Tratado Brasil-Itália exige dupla incriminação para a assistência relativa à execução de revistas pessoais, apreensão e sequestro de bens, dispensando-a para outras medidas $^{385}$. O Tratado Brasil-Peru ${ }^{386}$ também não dispensa a dupla incriminação para a execução de medidas que envolvam algum tipo de coerção e cita, em rol exemplificativo, os mandados de busca de pessoas e os registros, os confiscos, a indisponibilidade de bens, de sequestro com fim de prova e a interceptação telefônica.

Já no tratado Brasil-China, os Estados-partes podem recursar o pedido de assistência com base na ausência de dupla incriminação. Entretanto, a exigência de dupla incriminação não é um requisito intransponível e pode ser superada pelo Estado requerido nas circunstâncias em que isso se mostrar "apropriado"387.

De maneira geral, os tratados internacionais têm condicionado regras mais flexíveis para dupla incriminação, por exemplo, ao estabelecerem maior ou menor rigor quanto à exigência de dupla incriminação de acordo com o grau de intromissão da medida solicitada em assistência mútua. Adicionalmente, nas situações nas quais é obrigatória a existência de dupla incriminação, basta haver correspondência de elementos do tipo, ainda

\footnotetext{
380“'Os pedidos de assistência poderão ser recusados se os fatos ou omissões alegados que deram origem à solicitação não constituírem um delito previsto na legislação da parte requerida." (artigo $3^{\circ}$, Decreto n. 6.462, de 21 de maio de 2008).

${ }^{381}$ A ausência de dupla incriminação poderá ser motivo de recusa ao pedido de assistência (artigo $2^{\circ}$, "a"), mas os pedidos de busca e apreensão só serão atendidos pelo Estado requerido "se a infração for punível nos termos de sua legislação e se esta última permitir tais medidas nas mesmas circunstâncias, artigo $3^{\circ}$, inc. $3^{\circ}$ (Decreto n. 3.324, de 30 de dezembro de 1999).

382“Art. $2^{\circ}$. Dupla incriminação. 1. O auxílio só é prestado relativamente a fatos puníveis segundo as leis de ambas as partes. 2. Para os fins do presente artigo, na determinação da infração, segundo a lei de ambas as partes Contratantes, não releva que as suas leis qualifiquem ou tipifiquem diferentemente os elementos constitutivos ou utilizem a mesma ou diferente terminologia legal." (Decreto n. 1.320, de 30 de novembro de 1994).

383“"Art. $4^{\circ}$. Recusa ou adiamento da assistência. 1. A assistência poderá ser denegada se, no entendimento da parte requerida: d) a condita objeto da investigação, ação ou processo penal na parte requerente não constituir um delito nos termos da lei da parte requerida." (Decreto n. 5.721, de 13 de março de 2006).

384، Art. $6^{\circ}$. Medidas Coercitivas. A execução de pedido envolvendo medidas de coerção poderá ser recusada se os fatos nele descritos não corresponderem aos elementos objetivos de um delito tipificado pelo direito do Estado Requerido, supondo-se que tenha sido cometido neste Estado." (Decreto n. 6.974, de 7 de outubro de 2009).

${ }^{385}$ Artigo $2^{\circ}$, Decreto n. 862, de 9 de julho de 1993.

${ }^{386}$ Artigo $2^{\circ}$, inciso III, Decreto n. 3.988, de 29 de outubro de 2001.

${ }^{387}$ Artigo $1^{\mathrm{o}}$, inciso III, Decreto n. 6.282, de 3 de dezembro de 2007.
} 
que o nome dado ao delito pelo Estado requerente não seja propriamente o mesmo daquele dado pelo Estado requerido ${ }^{388}$.

No âmbito da União Europeia, em matéria de cautelares patrimoniais, o requisito da dupla incriminação foi reduzido para o cumprimento do chamado mandado europeu de congelamento de bens ou de provas ${ }^{389}$, como consequência direta do Princípio do reconhecimento mútuo das decisões judiciais, pedra angular do terceiro pilar.

A partir de 1996, já se previa na União Europeia a dispensa de dupla incriminação na extradição, em crimes considerados mais "graves". Para o mandado de congelamento de bens ou de provas, aumentou-se consideravelmente o rol de delitos para os quais não incide o princípio da dupla incriminação. Esses crimes são aqueles de tamanha gravidade, que são prejudiciais a uma ordem pública europeia e, por isso, devem ser incriminados por todos os Estados-Membros ${ }^{390}$.

A mitigação da dupla incriminação no âmbito da União Europeia tem gerado algumas críticas vinculadas às garantias fundamentais da pessoa atingida.

A primeira crítica diz respeito ao princípio da legalidade. O abandono do princípio da dupla incriminação pode levar a conflitos com o fundamento jurídico do Estado requerido relativo ao princípio da nulla poena ${ }^{391}$. Embora haja crimes considerados "graves", atentatórios a uma ordem pública europeia, os sistemas nem sempre são correspondentes. Isto porque não existe um sistema penal e processual penal europeu, pois são matérias ainda afetas ao direito interno dos Estados-Membros. As decisões dos órgãos comunitários em matéria penal e processual penal são tomadas, na maioria das vezes, no nível do terceiro pilar, requerendo a integração no âmbito interno por meio de lei.

É possível que os valores legais de um Estado "A" excluam a tipicidade de um fato que seja típico segundo o ordenamento jurídico do Estado "B”. Neste exemplo, se o Estado "B" solicitar de "A" a prisão do autor desse mesmo fato hipotético, será de se questionar se "A", como Estado requerido, não estará se colocando em contradição com

\footnotetext{
${ }^{388}$ No entendimento do Supremo Tribunal Federal, é irrelevante eventual variação terminológica registrada nas leis em confronto. Basta a presença dos elementos estruturantes do tipo penal, a "essentialia delicti" (Ext. 977/Portugal, Tribunal Pleno, Rel. Min. Celso de Mello, j. 25.05.2005).

${ }^{389}$ EUR-Lex. Decisão-Quadro 2003/577/JAI do Conselho de 22 de Julho de 2003. Disponível em: <http://eurlex.europa.eu/LexUriServ/LexUriServ.do?uri=OJ:L:2003:196:0045:0055:PT:PDF>. Acesso em: 21 dez. 2013.

${ }^{390}$ GARCÍA SÁNCHEZ, Beatriz. La extradición en el ordenamiento interno español, internacional y comunitario, cit., p. 69.

${ }^{391}$ SATZGER, Helmut; ZIMMERMANN, Frank. Dos modelos tradicionais de cooperação judicial ao princípio do reconhecimento mútuo: novos desdobramentos do verdadeiro paradigma da Cooperação Europeia em matéria penal, cit., p. 431.
} 
seus próprios valores jurídicos quando auxiliar a perseguir penalmente alguém por um fato que ele, "A", não considere como punível de acordo com seu direito interno ${ }^{392}$. Tal problema é muito recorrente no Mandado de Arresto Europeu, principalmente quanto aos crimes de dispensabilidade facultativa à dupla incriminação.

Em suma, a única cooperação jurídica internacional viável entre Estados democráticos de direito é aquela que integra a pessoa atingida e seus direitos fundamentais internacionalmente reconhecidos.

Como bem observa RAÚL CERVINI, o compromisso internacional na efetivação da assistência mútua em matéria penal (diante das novas modalidades de delitos chamados de transnacionais) deve encontrar seu limite natural na devida proteção dos direitos dos indivíduos, os destinatários de qualquer norma jurídica. Nessa linha de pensamento, a garantia da dupla incriminação faria sentido em ocasiões nas quais os direitos dos indivíduos restassem efetivamente ameaçados ${ }^{393}$.

Por isso, entendemos ser necessária a existência de dupla incriminação para o cumprimento de medidas cautelares patrimoniais.

Demonstramos que as medidas cautelares patrimoniais de natureza penal destinam-se a garantir utilidade e eficácia ao processo no que diz respeito aos efeitos automáticos da sentença penal condenatória transitada em julgado - a perda dos bens obtidos com os proventos da infração e a reparação do dano causado com a prática delituosa. A medida cautelar patrimonial deve sempre se referir à punição pelo específico crime objeto do processo que se pretende assegurar.

Nas medidas cautelares patrimoniais cumpridas em assistência, portanto, em razão do requisito da referibilidade, é imprescindível que os fatos sejam típicos à luz do ordenamento do Estado requerente. A referibilidade na cooperação internacional serve de importante critério para se mensurar a proporcionalidade e os limites da medida cautelar patrimonial requerida, os quais devem ser fixados no patamar necessário à garantia de eventual pena pecuniária a ser decretada no processo estrangeiro principal, também não podendo superar o montante do dano causado pelo delito específico em apuração.

\footnotetext{
${ }^{392}$ SATZGER, Helmut; ZIMMERMANN, Frank. Dos modelos tradicionais de cooperação judicial ao princípio do reconhecimento mútuo: novos desdobramentos do verdadeiro paradigma da Cooperação Europeia em matéria penal, cit., p. 430.

${ }^{393}$ CERVINI, Raul; TAVARES, Juarez. Princípios da cooperação judicial penal internacional no Protocolo do Mercosul, cit., p. 135.
} 
Ademais, também não se justifica o cumprimento de medidas cautelares patrimoniais em cooperação internacional para garantia de processo em que se apure fatos penalmente irrelevantes ao Estado requerido.

Na cooperação jurídica internacional, o centro da questão deve voltar-se ao concernido, sobre o qual integrará uma série de princípios de garantia penal, dentre os quais a dignidade da pessoa humana, a legalidade e relevância do bem jurídico. Quando se coloca medidas cautelares no âmbito da assistência mútua, está-se a falar em medidas que geram não somente gravame patrimonial irreparável, mas também atos de contrição judicial suscetíveis de atingir os direitos individuais mais relevantes da parte atingida.

Admitir o contrário permitirá, em futuro processo cooperacional para recuperação de ativos, a utilização dos bens constritos cautelarmente por um Estado em cujo contexto normativo, medida de igual monta, se nacional fosse, não se fadaria ao mesmo fim, pela ausência de incriminação. Mostra-se inconsistente a defesa de que, sob o manto da eficiência da cooperação, o país requerido aceite cumprir, para satisfação do processo estrangeiro, medida constritiva real que não tenha plausibilidade jurídica alguma à luz de seu próprio ordenamento interno.

Nesse compasso, há maneiras outras de garantir maior eficiência, eficácia e agilidade à cooperação jurídica internacional, no entanto, a nosso ver, não se pode admitir gravame à seara dos direitos fundamentais do concernido, sem que haja correspondência penalmente relevante entre o fato objeto do processo originário do pedido de cooperação e a órbita normativa penal do Estado requerido.

\subsubsection{Proibição do bis in idem}

O princípio da vedação de dupla persecução penal e dupla punição, denominado em grande parte dos ordenamentos pela milenar expressão latina ne bis in $i_{d e m}^{394}$, via de regra é associado à proibição do Estado de impor a um indivíduo uma dupla

\footnotetext{
${ }^{394}$ Uma parte da doutrina se refere ao princípio de non bis in idem, cf. CARO CORIA, Dino (El principio de "ne bis in idem" en la jurisprudencia del Tribunal Constitucional. Revista Brasileira de Ciências Criminais, São Paulo, ano 15, n. 66, maio/jun. 2007); (CRUZ, Rogério Schietti Machado. A proibição de dupla persecução penal (ne bis in idem): limites no direito brasileiro. 2007. Tese (Doutorado) - Faculdade de Direito da Universidade de São Paulo, São Paulo, 2007).
} 
sanção ou submetê-lo a duplo processo (ne bis), em razão da prática de uma mesma conduta delitiva $(\text { idem })^{395}$.

Ao contrário do que ocorre no Brasil, onde a manifestação do ne bis in idem remanesce tímida ${ }^{396}$, o princípio encontra abrigo em diplomas constitucionais estrangeiros. A proibição de dupla persecução penal está prevista expressamente nas constituições federais dos EUA ${ }^{397}$, da Alemanha ${ }^{398}$ e de Portugal ${ }^{399}$. No ordenamento jurídico italiano, o bis in idem é previsto no Código Processual Penal italiano, em seu artigo $649^{400}$.

Poucos países reconhecem a validade de sentenças estrangeiras em matéria penal (para aplicação em seu ordenamento jurídico nacional) sem ter, como base, um tratado internacional ${ }^{401}$. Nesses casos, aponta RODOLFO MAIA ${ }^{402}$, a consagração de um $n e$

${ }^{395}$ MAIA, Rodolfo Tigre. O princípio do ne bis in idem e a Constituição brasileira de 1988. Boletim Científico - Escola Superior do Ministério Público da União, Brasília, ano 4, n. 16, p. 11-75, jul./set. 2005.

${ }^{396}$ Embora a Constituição Federal de 1988 tenha sido silente, tem se entendido que o princípio do bis in idem, considerado em sua vertente processual, foi previsto implicitamente pelo legislador constituinte como derivação da dignidade da pessoa humana (artigo $1^{\circ}$, inciso III) e do princípio da intangibilidade da coisa julgada (artigo $5^{\circ}$, XXXVI, da CF). No campo infraconstitucional, encontramos manifestações da proibição de dupla persecução penal basicamente no Estatuto do Estrangeiro (Lei no 6.815/1980), no Código Penal e no Código de Processo Penal. A proibição de dupla persecução penal é prevista ainda no Pacto Internacional dos Direitos Civis e Políticos da ONU de 1966 e na Convenção Americana de Direitos Humanos (Pacto de São José da Costa Rica).

${ }^{397}$ Denominado double jeopardy clause, trata-se de garantia prevista na quinta emenda da Constituição dos EUA: "nor shall any person be subject for the same offence to be twice put in jeopardy of life or limb".

${ }^{398}$ Art. 103, III, da Lei Fundamental de 1949: "Ninguém pode ser apenado várias vezes pelo mesmo fato".

399،“Art. 29.5: Ninguém pode ser julgado mais do que uma vez pela prática do mesmo crime”.

400“'Art. 649. Divieto di un secondo giudizio. 1. L'imputato prosciolto o condannato con sentenza o decreto penale divenuti irrevocabili non può essere di nuovo sottoposto a procedimento penale per Il medesimo fatto, neppure se questo viene diversamente considerato per il titolo, per grado o per Le circostanze, salvo quanto disposto dagli artt. 69 comma 2 e 345".

${ }^{401}$ VERVAELE, John A.E. El principio ne bis idem en Europa: el Tribunal de Justicia y los derechos fundamentales en el espacio judicial europeo. Nueva Doctrina Penal, Buenos Aires, n. 1, p. 287-308, 2005.

${ }^{402}$ MAIA, Rodolfo Tigre. O princípio do ne bis in idem e a Constituição brasileira de 1988, cit., p. 42. Há de se indagar: sob o argumento de defender a soberania do Estado Brasileiro, seria razoável simplesmente fechar os olhos a uma dupla persecução por um mesmo fato, ainda que a questão tenha sido tratada e resolvida pela Justiça de um outro país? A regra da computação e desconto de pena adotada no Código Penal, por seu turno, também se mostra insuficiente como único critério de solução, quando se está diante de contextos jurídico-processuais penais que, diferente do sistema processual penal brasileiro, admitem a disponibilidade da ação penal e formas alternativas de resolução, como, v.g., acordos na esfera administrativa com imposição de pena pecuniária (gerando perdão tácito por parte do órgão acusatório), ressarcimento de eventual dano ou outros meios transacionais. Sob o argumento de se evitar eventual impunidade, pune-se o agente segundo o Código Penal Brasileiro, independentemente da legislação estrangeira, quando o território nacional tenha sido usado para a concretização de algum ato executório do delito ou se, mesmo tendo sido praticado no exterior, foi no Brasil onde tenha irradiado seus efeitos (adoção da Teoria da Ubiqüidade). Pune-se, ainda, o cidadão brasileiro inclusive pelo delito que tenha cometido no exterior. Contudo, não há qualquer regra que reconheça e discipline de maneira específica, no campo processual penal, eventual renúncia do jus puniendi do Estado brasileiro quando, pelo mesmo fato e com relação ao mesmo agente, outro Estado igualmente competente esteja apreciando a causa ou já lhe tenha dado alguma solução. Ora, no panorama jurídico internacional em que o Brasil está imerso, mostra-se incompatível a postura adotada pelo legislador de fincar-se em uma concepção de supremacia absoluta da ordem normativa interna, talvez motivada pelo entendimento da aplicação da lei como manifestação exclusiva da soberania nacional e pela desconfiança dos julgamentos realizados em tribunais estrangeiros. 
bis in idem internacional encontrava sérios entraves, porquanto, sob pretenso reconhecimento e proteção da soberania nacional ${ }^{403}$, costumeiramente "não se reconhece a ampla proteção de efeitos dos julgados penais ou de processos instaurados em um determinado estado na esfera do direito interno dos demais países".

Mesmo nos tratados e convenções internacionais nos quais o princípio do ne bis in idem encontra-se expressamente consagrado, referido princípio, ou fica restrito à sua concepção material apenas (a previsão de detração da pena imposta no estrangeiro, por si, não impede o nascimento de uma segunda ação penal pelo mesmo fato), ou tem seu horizonte de atuação subjugado à soberania dos Estados pactuantes, o que, implicitamente, possibilita a convivência permanente de diversos procedimentos penais em seus diferentes estágios, diante da proteção das regras da extraterritorialidade incondicionada e da territorialidade absoluta, adotadas, inclusive, pelo ordenamento jurídico pátrio ${ }^{404}$.

Quando se está diante de delitos envolvendo diferentes territórios nacionais, torna-se, pois, problemático o reconhecimento da condição da res judicata de uma sentença penal estrangeira, como supedâneo a impedir o processamento ou o julgamento do agente pelos mesmos fatos ${ }^{405}$.

Mesmo no âmbito europeu - o bis in idem figura como princípio geral do direito comunitário, segundo o art. $4^{\circ}$, do Protocolo 7 do CEDH - ${ }^{406}$, discute-se a

Também entendemos tratar-se de matéria processual e não de direito penal, relativa à competência e litispendência erigida ao nível internacional. A simples comutação da pena cumprida no exterior não resolve a questão se ainda se mantém aberta a porta à dupla persecussão sobre um mesmo fato e contra um mesmo autor em diferentes países. Adotando-se a realidade europeia como paradigma, talvez um avanço a ser conquistado no âmbito do Mercosul.

${ }^{403}$ No campo internacional, o critério da territorialidade é fator relevante para estabelecer a aplicação da lei penal no espaço. Nesse sentido, sob o ponto de vista da soberania de um Estado independente, remanesce o princípio geral de que é no espaço sujeito à soberania do Estado onde se definirá o exercício do jus puniendi. GARCÍA SÁNCHEZ, Beatriz. El principio de justicia universal en ordenamiento interno y internacional. Disponível em: <http://eciencia.urjc.es>. Acesso em: 30 ago. 2013.

${ }^{404}$ MAIA, Rodolfo Tigre. O princípio do ne bis in idem e a Constituição brasileira de 1988, cit., p. 42.

${ }^{405}$ VERVAELE, John A.E. El principio ne bis idem en Europa: el Tribunal de Justicia y los derechos fundamentales en el espacio judicial europeo, cit., p. 288. Segundo o autor, grande parte dos países do commom law reconhece o efeito da res judicata das sentenças estrangeiras. Nos países do civil law, com exceção dos chamados Países Baixos (os quais "ciertamente tienen la disposición más liberal y de más largo alcance"), há, de uma maneira geral, relutância para o reconhecimento do bis in idem sob uma perspectiva internacional.

${ }^{406} \mathrm{~A}$ evolução do princípio do ne bis in idem internacional entre os países da Europa Continental levou ao entendimento de que, além de reconhecer e aplicar no âmbito interno as sentenças proferidas por outra jurisdição, seria preciso, ainda, uma melhor integração entre os Estados na coordenação das investigações e procedimentos penais em curso em seus territórios, a fim de evitar dupla persecução e resoluções contraditórias. Diante do problema cada vez mais frequente da criminalidade transnacional, não bastava a aplicação das regras internacionais do ne bis in idem (com o único fito de reconhecer internamente os efeitos de decisões proferidas dentro e/ou fora de cada jurisdição). Seria preciso ampliar o âmbito de aplicação internacional do ne bis in idem em sua vertente processual, criando mecanismos de evitar 
incidência do princípio do ne bis in idem nos convênios de cooperação jurídica internacional.

A advertência para a vedação à reiteração (bis) da investigação ou da persecução não ganha tanta relevância na cooperação jurídica no âmbito comunitário quando se propõe a analisar a ocorrência dos mesmos fatos (in idem). É perfeitamente possível haver situação na qual os fatos objeto do feito que deu ensejo ao pedido de auxílio mútuo correspondam aos fatos de procedimento penal em trâmite ou já julgados definitivamente perante o Estado ao qual se requer a cooperação ou perante um terceiro Estado, que não seja o Estado emissor nem o receptor do pedido de auxílio mútuo. A questão posta é profundamente analisada por MÁRIO PISANI ${ }^{407}$.

A Decisão-marco 2003/577/JAI, de 22 de julho de $2003^{408}$, sobre a execução na União Europeia das Decisões relativas ao sequestro cautelar de bens e de garantia de provas, em seu artigo $7^{\circ}$, prevê, dentre os motivos de denegação do pedido de sequestro ou de garantia probatória, a violação do princípio do ne bis in idem. Relevante enfatizar que a decisão quadro está inserida no âmbito do direito comunitário, por seu terceiro pilar (mútua confiança) e não abarca decisões proferidas por Estados não pertencentes à União Europeia. Portanto, o reconhecimento de processo ou de sentença estrangeira relativos a países não comunitários é decisão afeta à competência interna de cada Estado europeu.

O princípio do ne bis in idem é consagrado em grande parte dos tratados bi e multilaterais sobre cooperação jurídica internacional firmados com o Estado brasileiro. Resumidamente, se houver, perante o Estado requerente ou requerido, decisão transitada

conflitos de jurisdição em matéria penal. A respeito do princípio do ne bis in idem em sua vertente internacional, v. VERVAELE, John A.E. El principio ne bis idem en Europa: el Tribunal de Justicia y los derechos fundamentales en el espacio judicial europeo, cit.; COLOMER HERNÁNDEZ, Ignacio. Conflictos de jurisdicción, non bis in idem y litispendencia internacional en la Unión Europea. In: ARROYO ZAPATERO, Luis; NIETO MARTIN, Adán (Coord.). El principio de ne bis in idem en el derecho penal europeo e internacional. Cuenca: Universidad de Castilla-La Mancha, 2007; CONSOLO, Claudio. Profili della litispendencia internazionale. Rivista di Diritto Internazionale, Milano, v. 80, n. 1, p. 5-77, 1997; BARDAJÍ, Salvador Viada. Coordinación de procedimientos en casos conexos o cuando tengan jurisdicción distintos tribunales: transferencia de procedimientos. Revista del Ministerio Fiscal, n. 9, 2009.

${ }^{407}$ PISANI, Mario. Ne bis in idem y cooperación judicial europea. In: ARROYO ZAPATERO, Luis; NIETO MARTIN, Adán (Coord.). El principio de ne bis in idem en el derecho penal europeo e internacional. Cuenca: Universidad de Castilla-La Mancha, 2007.

408“Art. $7^{\circ}$ - Motivos para o não reconhecimento ou a não execução:

1. As autoridades judiciárias competentes do Estado de execução só podem recusar o reconhecimento ou a execução da decisão de sequestro se:

(...)

c) Decorrer claramente das informações constantes da certidão que a prestação de auxílio judiciário, nos termos do artigo $10^{\circ}$, relativamente à infração que motivou a decisão de congelamento seria contrária ao princípio do ne bis in idem." 
em julgado sobre a) o mesmo fato sobre o qual diga respeito o pedido de cooperação internacional e b) a pessoa atingida pela medida, não há que ser atendido a pedido cooperação jurídica internacional. Frise-se: o bis in idem, hábil a inviabilizar a cooperação, somente ocorre com o trânsito em julgado da decisão e se a coisa julgada se voltar aos mesmos fatos e ao mesmo concernido.

Nessa toada, alguns problemas concretos merecem apreço.

Uma primeira questão diz respeito à possibilidade de verificação do ne bis in idem quando o fato já estiver prescrito. Apenas o tratado Brasil-Espanha prevê tal possibilidade. E a questão revela-se ainda mais espinhosa quando envolve, por exemplo, medidas cautelares patrimoniais.

Conforme já foi tratado no primeiro capítulo da presente dissertação, de acordo com o critério da referibilidade, qualquer cautelar penal deve se referir à garantia da punição por um crime específico. Por isso, defendemos traduzir em absoluta violação à ordem pública nacional, face ao disposto nos incisos II, XXII e LIV, do artigo $5^{\circ}$, da Constituição Federal, permitir que alguém sofra, no Brasil, constrição de bens em razão de fatos que, à luz da legislação penal pátria, encontrem-se prescritos, mesmo que o delito tenha sido cometido no exterior e que a medida se destine garantir a eficácia de processo estrangeiro. $\mathrm{O}$ advento da prescrição opera como cláusula limitadora do dever agir do Estado, sendo o direito à propriedade assegurado pela Ordem Constitucional brasileira (art. $5^{\circ}$, caput), sem qualquer distinção entre brasileiros e estrangeiros ${ }^{409}$.

A prescrição penal está intimamente ligada à segurança jurídica e representa verdadeira limitação ao jus puniendi estatal ${ }^{410}$, na medida em que, ao cidadão, o temor de ser punido não lhe pode ser usado como instrumento eterno de perturbação psíquica, moral e social, como uma espada de Dâmocles apontada permanentemente contra si. Conforme preceitua Aníbal Bruno, “nem a razão, nem a humanidade, nem mesmo o interesse social

\footnotetext{
${ }^{409}$ Em sentido contrário, v. WEBER, Patrícia Nuñez. A cooperação jurídica internacional em medidas processuais penais, cit., p. 100.

${ }^{410}$ Pode-se dizer que a prescrição está inserida na Constituição Federal, postulada nos princípios do Estado democrático de direito, sobretudo no que se refere à dignidade da pessoa humana e à tutela do ius libertatis do cidadão. Implica dizer: ainda que a lei penal tenha sido violada, pela passagem do tempo, gera-se o risco de que a aplicação da pena ocorra ao arrepio dos postulados preventivos gerais positivos, em afronta à dignidade humana do cidadão. Portanto, a prescrição serve de instituto garantista contra o abuso do próprio Estado. (MACHADO, Fábio Guedes de Paula. Prescrição penal: prescrição funcionalista. São Paulo: Ed. Revista dos Tribunais, 2000. p. 190).
} 
tornariam admissível deixar pesar sobre o criminoso indefinitivamente a ameaça do processo ou da execução da pena" ${ }^{411}$.

Nos tratados Brasil-Peru e Brasil-China, está previsto que o pedido de cooperação jurídica internacional pode ser denegado quando, em razão dos mesmos fatos e em relação à mesma parte, houver processo no Estado requerido extinto em virtude da prescrição. Neste caso, a solução parece-nos menos espinhosa, porque o reconhecimento da prescrição (e consequente extinção do processo) é decisão terminativa de mérito, que faz coisa julgada material. Está presente, portanto, “decisão final” sobre o mesmo fato, sujeita ao reconhecimento de bis in idem.

Outra importante questão coloca-se no caso em que, perante o Estado requerido, já haja arquivamento, por ausência de provas, de inquérito policial que verse sobre os mesmos fatos e em relação à mesma parte atingida no pedido de cooperação jurídica internacional. Nenhum tratado, nem bi, nem multilateral de que o Brasil seja signatário previu tal possibilidade. Nos termos do artigo 18, do Código de Processo Penal, a investigação policial pode ser retomada se houver novas provas e, obviamente, se não estiver operada a extinção da punibilidade estatal pelo advento da prescrição. Assim, como a decisão de arquivamento de inquérito policial só faz coisa julgada formal, permitindo posterior ajuizamento de ação penal, entendemos que o cumprimento da cooperação jurídica internacional não violaria o princípio do ne bis in idem.

Por outro lado, se a ausência de acervo provatório mínimo à demonstração da tese acusatória levar à absolvição da pessoa atingida em relação aos mesmos fatos que ensejaram o pedido de cooperação internacional, este deverá ser denegado pelo Brasil, com base no princípio do ne bis in idem. Isso porque não se admite no direito processual penal brasileiro a rescisão da coisa julgada material para prejudicar o réu; nem mesmo posterior colheita de novos elementos indiciários teria o condão de fazer ressurgir a persecução contra o acusado absolvido por insuficiência de provas, se a decisão já tiver transitado em julgado.

Por fim, uma última questão diz respeito àqueles crimes que devem ser objeto de punição segundo a lei brasileira, mesmo quando já houver condenação ou absolvição no

\footnotetext{
${ }^{411}$ BRUNO, Aníbal. Direito penal: parte geral. Rio de Janeiro: Forense, 1966. t. 3, p. 210.
} 
estrangeiro. São as situações previstas no artigo $7^{\circ}$, I, do Código Penal ${ }^{412}$, bem como os crimes previstos nos artigos 28 e 29 da Lei de Segurança Nacional (Lei 7.170/83) ${ }^{413}$.

A exemplo do que ocorre em outras legislações alienígenas, a incidência dessa extraterritorialidade incondicionada, a ensejar o exercício obrigatório do jus puniendi nesses casos, justifica-se pelo princípio da defesa ou da proteção ${ }^{414}$. O pedido de cooperação jurídica internacional deve ser atendido quando diz respeito a umas das hipóteses elencadas no art. $7^{\circ}$, do Código Penal, porque a existência de processo ou mesmo decisão definitiva ou com força de definitiva com trânsito em julgado no exterior não impede a responsabilização do agente, no Brasil, segundo a lei penal brasileira. Trata-se, portanto, de exceção ao princípio do ne bis in idem.

\subsubsection{Locus regit actum}

Já estabelecia o Código de Bustamante a necessidade da observância da lei processual do estado requerido quanto à forma de cumprimento das diligências solicitadas, orientada pelo princípio do locus regit actum ${ }^{415}$. Disposição semelhante foi reproduzida na Lei de Introdução às normas do direito Brasileiro ${ }^{416}$.

O princípio do locus regit actum está previsto em todos os tratados bilaterais firmados pelo Brasil ${ }^{417}$, sendo visto também nos tratados multilaterais ${ }^{418}$. A merecer destaque, o artigo 22 do Protocolo de Assistência Jurídica Mútua em Assuntos Penais -

\footnotetext{
${ }^{412}$ De acordo com o artigo $7^{\circ}$, inciso I, do Código Penal, são os crimes contra a vida ou a liberdade do Presidente da República (alínea "a"); contra o patrimônio ou a fé púbica da União, do Distrito Federal, de Estado, de Território, de Município, de empresa pública, sociedade de economia mista, autarquia ou fundação instituída pelo Poder Público (alínea "b"); contra a administração pública, por quem está a seu serviço (alínea "c"); de genocídio, quando o agente for brasileiro ou domiciliado no Brasil (alínea "d").

${ }^{413}$ Discorrem sobre os crimes de atentado contra a liberdade pessoal ou contra a vida do Presidente da República, do Presidente do Senado Federal, do Presidente da Câmara dos Deputados ou do Presidente do Supremo Tribunal Federal.

${ }^{414}$ NUCCI, Guilherme de Souza. Código Penal comentado. São Paulo: Ed. Revista dos Tribunais, 2000. p. 73.

${ }^{415} \mathrm{O}$ Código de Bustamante foi incorporado ao ordenamento jurídico brasileiro por meio do Decreto $\mathrm{n}$. 18.871, de 13 de agosto de 1929. Em seu artigo 391, previa: "Aquelle que recebe a carta ou comissão rogatória se deve sujeitar, quanto ao seu objecto, à lei do deprecante e, quanto à forma de a cumprir, à sua própria lei”.

${ }^{416}$ Artigo 12, parágrafo $2^{\circ}$ : “A autoridade judiciária brasileira cumprirá, concedido o exequatur e segundo a forma estabelecida pele lei brasileira, as diligências deprecadas por autoridade estrangeira competente, observando a lei desta, quanto ao objeto das diligências."

${ }^{417}$ Tratado Brasil-Cuba (art. 1 ${ }^{\circ}$, I), Brasil-China (art. $6^{\circ}$, II), Brasil-EUA (art. $5^{\circ}$, III), Brasil-Colômbia (art. $7^{\circ}$, I), Brasil-França (art. $3^{\circ}$, II), Brasil-Itália (art. $8^{\circ}$, I), Brasil-Peru ( $8^{\circ}$, I), Brasil-Portugal (art. $4^{\circ}$, I), BrasilCoreia (art. $\left.6^{\circ}\right)$, Brasil-Ucrânia (5 $\left.5^{\circ}, \mathrm{III}\right)$, Brasil-Espanha (art. 6.3, "d"), Brasil-Suíça (art. $5^{\circ}$, II), BrasilSuriname (art. $5^{\circ}$, IV, “f”).

${ }^{418}$ A título de exemplo: Convenção Interamericana sobre Assistência Mútua em matéria penal, art. 10; Protocolo do Mercosul de Assistência Jurídica Mútua em Assuntos Penais, art. $7^{\circ}$, I.
} 
Mercosul, que trata das medidas cautelares ("medidas acautelatórias de bens"), prevê, em seu parágrafo primeiro, última parte, que a "medida será efetivada de acordo com a lei processual e substantiva do Estado requerido".

Ressalvada disposição específica em tratado internacional, o Estado requerente não pode impor sua legislação processual para cumprimento de pedidos de cooperação jurídica internacional pelo Estado requerido, pois significaria violação à soberania do Estado requerido e pretensão de conferir efeitos extraterritoriais às opções processuais do Estado requente. Deste modo, por exemplo, qualquer pedido de extradição feito ao Brasil submeter-se-á às regras previstas na Lei n. 6.815/1980, assim como os pedidos de medidas cautelares patrimoniais serão cumpridos de acordo com as regras pertinentes previstas na legislação brasileira ${ }^{419}$.

Isso não impede que o Estado requerente preste orientações relevantes sobre o funcionamento de seu processo penal interno e quanto à obtenção e manuseio das informações e documentos relativos ao pedido de assistência. Permite-se, assim, ao Estado requerente solicitar formalidades específicas e imprescindíveis para o ato a ser cumprido em assistência mútua, a fim de torná-lo adequado ao seu ordenamento ${ }^{420}$.

Desde que não viole a ordem pública do Estado requerido, a recomendação do Estado requerente deve ser atendida na maior medida possível, buscando-se maior eficiência na cooperação. Quaisquer orientações para o cumprimento da diligência devem ser especificadas de forma clara no próprio pedido de cooperação. A possibilidade de adoção das formalidades específicas solicitadas pelo Estado requerente está prevista em grande parte dos tratados bilaterais e multilaterais firmados pelo Brasil $^{421}$.

Costumeiramente, a título de exemplo, pedidos de cooperação ativa do Brasil objetivando o interrogatório do acusado no exterior têm sido instruídos pelas formalidades previstas no artigo 186 do Código de Processo Penal, mormente quanto à advertência ao interrogando, antes do ato, sobre o direito de permanecer calado e de não responder perguntas que lhe forem formuladas, sendo que o silêncio não importará em confissão nem poderá ser interpretado em desfavor da defesa. Tratando-se de formalidade intrínseca ao

\footnotetext{
${ }^{419}$ MORO, Sérgio Fernando. Cooperação jurídica internacional em casos criminais: considerações gerais, cit., p. 27.

${ }^{420}$ WEBER, Patrícia Nuñez. A cooperação jurídica internacional em medidas processuais penais, cit., p. 103.

${ }^{421}$ Estabelece-se, em geral, que os pedidos de assistência serão executados conforme a legislação da parte requerida e, desde que não vedado naquela legislação, do modo solicitado pela parte requerente.
} 
ato de acordo com as normas da legislação brasileira, a advertência à autoridade do Estado requerido mostra-se importante para prevenir eventual invalidação do interrogatório.

Alguns tratados apresentam cláusulas que limitam o escopo da assistência mútua a depender do objeto ou da parte interessada, como é o caso do MLAT Brasil-EUA, ao prever que o acordo destina-se apenas à assistência judiciária mútua entre os Estados partes. Seus dispositivos, portanto, não dão direito a qualquer indivíduo de obter, suprimir ou excluir qualquer prova, nem de impedir que uma solicitação seja atendida (artigo I, n. $5^{422}$ ). Semelhante regra está imposta no Tratado Brasil-Ucrânia, em seu artigo $1^{\circ}$, inciso IV, bem como no artigo $1^{\circ}$, II, do Protocolo de San Luís - Mercosul.

Indubitavelmente, a restrição ao cumprimento da assistência mútua no interesse exclusivo da defesa, contida no MLAT Brasil-EUA (incorporado ao ordenamento jurídico brasileiro pelo Decreto n. 3.810, de 2 de maio de 2001), levanta dúvida na doutrina quanto à sua constitucionalidade, por ofensa, seja ao princípio da ampla defesa ${ }^{423}$, seja ao princípio da isonomia, na vertente da paridade de armas no processo penal ${ }^{424}$. Contudo, a resolução deste impasse esbarra diretamente na regra do locus regit actum.

Ademais, o princípio do locus regit actum tem gerado discussões relevantes em matéria de medidas cautelares patrimoniais. Cite-se, por exemplo, o caso em que a legislação do Estado requerente dispense ordem judicial prévia às medidas cautelares, ou

\footnotetext{
422 “5. O presente Acordo destina-se tão-somente à assistência judiciária mútua entre as partes. Seus dispositivos não darão direito a qualquer indivíduo de obter, suprimir ou excluir qualquer prova ou impedir que uma solicitação seja atendida".

423“"Evidentemente, tal limitação ofende o princípio da ampla defesa, no que diz respeito ao acesso aos meios de recursos a ela inerentes (artigo $5^{\circ}, \mathrm{LV}$, da Constituição) e qualquer tratado que assim disponha pode ser submetido ao controle de constitucionalidade para interpretação conforme. Assim, a autoridade central brasileira não poderá recusar a tramitação de pedidos da defesa destinados ao exterior. Contudo, é quase certo que em muitos casos os Estados estrangeiros manifestarão recusa a solicitações desta ordem, porque os instrumentos de assistência recíproca são considerados privilégios dos órgãos estatais de persecução na luta contra a criminalidade transnacional. Portanto, a não ser que haja permissão expressa no texto do MLAT ou que a praxe entre as nações cooperantes o admitam, não terão seguimento no exterior os pedidos de exclusivo interesse e iniciativa da defesa para a utilização em ações penais em curso no Brasil" (ARAS, Vladmir. O papel da autoridade central nos acordos de cooperação penal internacional, cit., p. 83-84).

${ }^{424}$ CRISSIUMA, Marcos Vidigal de Freitas. A inconstitucionalidade e ilegalidade do acordo de cooperação mútua internacional firmado entre o Brasil e os Estados Unidos da América (MLAT). Boletim IBCCRIM, São Paulo, v. 17, n. 205, p. 10-11, dez. 2009. O MLAT Brasil-EUA nunca foi objeto de declaração de inconstitucionalidade perante o STF, que, inclusive, já o examinou em diversas ocasiões. Porém, o Tribunal Regional Federal da $3^{\mathrm{a}}$ Região, interpretando o alcance do MLAT Brasil-EUA, pronunciou-se no sentido de que a inserção de tal diploma internacional no ordenamento jurídico brasileiro não padece de inconstitucionalidade por afronta aos princípios da isonomia processual, contraditório e ampla defesa: "O que ocorre, na verdade, é uma recusa do Estado americano em proceder a oitiva de testemunhas arroladas pela defesa, fundamentando tal negativa nos princípios norteadores do sistema do Common Law, adotado por aquele país, segundo o qual referidas diligências são realizadas às custas da defesa, pouco importando se os réus são americanos ou estrangeiros" (TRF-3 ${ }^{\text {a }}$ Região, HC n. 2010.03.00.030380-2, Rel. Des. Fed. Cotrim Guimarães, $2^{\mathrm{a}}$ Turma, j. 15.03.2011).
} 
mesmo quando autoriza que o Ministério Público as requeira diretamente. Neste caso, há de se questionar se o pedido de assistência deve ou não ser negado pelo Brasil, por atentar à ordem pública nacional.

$\mathrm{Na}$ via reversa, sendo o Brasil o Estado requerente de medida cautelar a determinado Estado cuja legislação dispense autorização judicial, não poderia o Brasil impor ao Estado requerido procedimento diverso daquele previsto em seu ordenamento. Diante disso, para que a diligência rogada seja admitida em solo nacional depois de cumprida, cabe questionar se não deveria haver decisão judicial pela autoridade brasileira competente antes da expedição do pedido de auxílio, mesmo que no país destinatário tal decisão fosse absolutamente desnecessária ${ }^{425}$.

\subsubsection{Instrumentos de cooperação jurídica internacional usados às medidas cautelares patrimoniais penais}

Grosso modo, são modalidades de cooperação jurídica internacional no Brasil: a extradição, a carta rogatória, o auxílio direto, a homologação de sentença estrangeira, a informação do direito estrangeiro e a transferência de presos e de processos.

Ao objetivo da dissertação, interessa-nos especificamente a carta rogatória e o auxílio direto, porque são os instrumentos adequados para o cumprimento de medidas cautelares patrimoniais em cooperação jurídica internacional ativa e passiva.

A carta rogatória e o auxílio direto fazem parte da chamada assistência jurídica internacional em matéria penal, que engloba os pedidos de auxílio internacional em atos de preparação e desenvolvimento do processo penal ${ }^{426}$.

\subsubsection{Carta Rogatória}

Carta rogatória é o instrumento de assistência jurídica pelo qual um Estado (rogante) solicita à autoridade de outro Estado (rogado) a realização de determinada diligência $^{427}$, que vai desde meras citações, notificações e cientificações (chamados atos ordinários ou de mero trâmite); passando por coleta de provas (atos instrutórios), tais como

\footnotetext{
${ }^{425}$ Tal tema será analisado com maior profundidade no capítulo IV, no qual cuidaremos das medidas cautelares patrimoniais na cooperação jurídica na carta rogatória e no auxílio direto.

${ }^{426}$ ABADE, Denise Neves. Direitos fundamentais na cooperação jurídica internacional: extradição, assistência jurídica, execução de sentença estrangeira e transferência de presos, cit., p. 309.

${ }^{427}$ ARAÚJO, Nádia de (Coord.). Cooperação jurídica internacional no Superior Tribunal de Justiça: comentários à Resolução nº 9/2005, cit., p. 72.
} 
oitiva de testemunha e interrogatório; até atos de cunho cautelar (busca e apreensão, arresto e sequestro de bens) $)^{428}$.

A carta rogatória foi o primeiro instrumento de assistência jurídica a ser incorporado ao ordenamento jurídico brasileiro e ainda é o mais recorrente, apesar de novos instrumentos já serem aceitos e utilizados.

No Brasil, a regulamentação para o cumprimento de cartas rogatórias passivas existe desde meados do século XIX, mas somente a Lei n. 221, de 10 de novembro de 1894 instituiu um procedimento prévio de admissibilidade às cartas rogatórias de natureza penal $^{429}$. De acordo com seu artigo 12 , parágrafo $4^{\circ}$, as cartas rogatórias emanadas do Estado estrangeiro só poderiam ser cumpridas após o exequatur (cumpra-se) ${ }^{430}$ outorgado pelo Governo Federal. A Lei 221/1894 também vedava a concessão do exequatur para as chamadas medidas de "caráter executório".

A Constituição Federal de 1934 modificou a competência para a concessão do exequatur, do Poder Executivo ao Poder Judiciário, especificamente ao Supremo Tribunal Federal, padrão este mantido pelas Constituições subsequentes. Malgrado já tenha sido revogada a proibição para execução de cartas rogatórias de caráter executório, instituída na Lei $n^{\circ} 221 / 1894$, mesmo assim o STF a manteve em sua jurisprudência ${ }^{431}$. Sustentava-se, para tal negativa, que a coercividade da medida deprecada - considerada de "execução forçada" - implicaria desrespeito à ordem pública ${ }^{432}$.

Com a recente alteração instituída pela EC n. 45 à Constituição Federal de 1988, a competência para o exequatur foi novamente alterada, desta vez para o Superior

\footnotetext{
${ }^{428}$ ARAÚJO, Nádia de (Coord.). Cooperação jurídica internacional no Superior Tribunal de Justiça: comentários à Resolução $n^{\circ}$ 9/2005, cit., p. 8. Neste sentido, de acordo com a nova sistemática introduzida pela Resolução $\mathrm{n}^{\circ} 9$ do STJ, artigo $7^{\circ}$, os pedidos em carta rogatória podem ser classificados como: atos ordinatórios ou de comunicação processual (citação, notificação ou intimação de pessoas físicas ou jurídicas domiciliadas no território do Estado requerido); atos instrutórios (destinados à coleta de provas testemunhais, materiais e documentais - no território do Estado requerido); e atos executórios ou de caráter restritivo (atos como sequestro, arresto e penhora de bens situados no território do Estado requerido).

${ }^{429}$ Antes do Aviso Circular n. $1^{\circ}$, de 1847, era comum juízes brasileiros receberem as cartas rogatórias diretamente da autoridade do Estado requerente - na maioria dos casos, de Portugal -, cumprindo-as sem que o governo imperial tomasse conhecimento (ARAÚJO, Nádia de (Coord.). Cooperação jurídica internacional no Superior Tribunal de Justiça: comentários à Resolução no 9/2005, cit., p. 9).

${ }^{430}$ Exequatur é o "cumpra-se" emitido após o juízo de delibação da jurisdição brasileira à ordem emanada de outra jurisdição.

${ }^{431}$ ARAÚJO, Nádia de (Coord.). Cooperação jurídica internacional no Superior Tribunal de Justiça: comentários à Resolução no 9/2005, cit., p. 72.

432 "CARTA ROGATÓRIA EXECUTORIA. INADMISSIBILIDADE. SEQUESTRO, IMPORTANDO EXECUÇÃO FORÇADA.” (CR n. 337, Tribunal Pleno, Rel. José Linhares, j. 1953). No mesmo sentido, v. STF, CR n. 3.237, Decisão monocrática do Min. Presidente, 1980
} 
Tribunal de Justiça. Este Tribunal acabou modificando a posição anterior do STF quanto à proibição de concessão de exequatur às medidas de caráter executório e incluiu permissão expressa nesse sentido na Resolução n. 9/2005, ao estabelecer, em seu artigo $7^{\circ}$, que: "As cartas rogatórias podem ter por objeto atos decisórios ou não decisórios" ${ }^{\text {433. }}$.

Não será todo pedido de assistência jurídica encaminhado por autoridade estrangeira a autoridades brasileiras que se enquadrará ao conceito de "carta rogatória", mesmo que o pedido de assistência venha rotulado como tal. Dentre o universo de medidas sujeitas à cooperação internacional, haverá as que exigem e as que dispensam o prévio juízo de delibação do STJ como condição de cumprimento no território brasileiro. Dispensam evidentemente exequatur os pedidos relativos à chamada cooperação administrativa ${ }^{434}$, como, por exemplo, a troca de informações não acobertadas por sigilo judicial.

Para grande parte dos casos, entretanto, a indefinição legislativa gera dúvida sobre os atos estrangeiros que precisariam passar pelo juízo de delibação do Superior Tribunal de Justiça antes de irradiarem efeitos no Brasil.

GILSON DiPP leciona que o juízo de delibação levado a efeito nos pedidos de cooperação traz em seu bojo alguma decisão estrangeira de ordem judicial ${ }^{435}$, "mesmo que de natureza meramente processual, geralmente destinada a impulso processual" ${ }^{436}$. As

\footnotetext{
${ }^{433} \mathrm{~A}$ questão do cumprimento de medidas de caráter executório em cartas rogatórias e o reflexo nas medidas cautelares patrimoniais penais serão tratados no item 2.4 do presente capítulo.

${ }^{434} \mathrm{Na}$ cooperação administrativa internacional, solicita-se o cumprimento de ato de natureza administrativa ou judicial sem conteúdo jurisdicional, mesmo quando a solicitação advém de autoridade judiciária, tal como a solicitação de dados cadastrais não acobertados de sigilo ou pedido de esclarecimentos ao Estado requerente acerca da vigência de determinada norma no país. Pedidos dessa envergadura são atendidos na maioria dos casos diretamente pela Autoridade Central, independentemente de retransmissão a outros órgãos ou autoridades nacionais (VERGUEIRO, Luiz Fabricio Thaumaturgo. Apontamentos gerais sobre a cooperação jurídica internacional e suas modalidades, cit., p. 384).

${ }^{435}$ De acordo com a jurisprudência do STJ, a competência constitucional para a concessão do exequatur diz respeito aos pedidos oriundos de autoridade judicial para a realização de atos processuais em território brasileiro. Logo, o termo "atos decisórios" constante no art. $7^{\circ}$ refere-se às decisões emanadas exclusivamente do Poder Judiciário. Neste sentido: "Ao atribuir ao STJ a competência para a concessão de exequatur às cartas rogatórias (art. 105, I, i), a Constituição está se referindo, especificamente, ao juízo de delibação consistente em aprovar ou não o pedido feito por autoridade judiciária estrangeira para cumprimento, em nosso país, de diligência processual requisitada por decisão do juiz rogante. É com esse sentido e nesse limite, portanto, que deve ser compreendida a referida competência constitucional." Dessa forma, conclui a Corte: "Não são inconstitucionais as cláusulas dos tratados e convenções sobre cooperação jurídica internacional (v.g. art. 46 da Convenção de Mérida - 'Convenção das Nações Unidas contra a Corrupção' e art. 18 da Convenção de Palermo - 'Convenção das Nações Unidas contra o Crime Organizado Transnacional') que estabelecem formas de cooperação entre autoridades vinculadas ao Poder Executivo, encarregadas da prevenção ou da investigação penal, no exercício das suas funções típicas. A norma constitucional do art. 105, I, i, não instituiu o monopólio universal do STJ de intermediar essas relações. A competência ali estabelecida - de conceder exequatur a cartas rogatórias -, diz respeito, exclusivamente, a relações entre os órgãos do Poder Judiciário, não impedindo nem sendo incompatível com as outras formas de cooperação jurídica previstas nas referidas fontes normativas internacionais." (Rcl 2645/SP, Min. Teori Zavascki, Corte Especial, DJe 16/12/2009, p. 308).

${ }^{436}$ DIPP, Gilson. Cartas rogatórias e cooperação jurídica internacional. In: MANUAL de cooperação jurídica internacional e recuperação de ativos: cooperação em matéria penal. Brasília: Ministério da Justiça, 2008. p. 31.
} 
cartas rogatórias têm por objeto, portanto, determinações judiciais proferidas por autoridades estrangeiras, podendo ser não decisórias (citações, intimações e produção de provas) e decisórias não definitivas (medidas cautelares) ${ }^{437}$.

Estes atos judiciais estrangeiros precisam ser delibados pelo Superior Tribunal de Justiça para terem eficácia no território brasileiro, mediante a concessão do cumpra-se. Com efeito, por previsão constitucional (artigo 102, I, "i”, CF), o Estado vê-se forçado a intervir no procedimento rogado, na medida em que existe ali uma decisão já tomada por órgão sob a jurisdição de outro Estado e que deverá ser cumprida em solo nacional ${ }^{438}$.

Assim, ao receber o pedido de diligência em carta rogatória, o STJ exerce o juízo de delibação da decisão/solicitação estrangeira, ou seja, verifica os requisitos formais e, excepcionalmente, o mérito do pedido $^{439}$, para aferir a compatibilidade do ato rogado com o ordenamento jurídico interno ${ }^{440}$. Quanto aos requisitos formais, o artigo $9^{\circ}$, da Resolução n. 9/2005, do STJ exige a autenticidade dos documentos que instruem a carta rogatória, que seriam todos aqueles necessários à boa compreensão e execução no território brasileiro. Os requisitos materiais, por sua vez, exigem respeito à soberania nacional e à ordem pública $^{441}$. Segundo DIPP, “o papel do STJ, como juízo de delibação, não é o de analisar fatos, provas e produzir decisões originárias, mas de permitir ou não que decisões estrangeiras tenham eficácia no território nacional" ${ }^{\natural 42}$.

Por outro lado, se não houver decisão estrangeira nem questão sujeita a delibação pelo Superior Tribunal de Justiça, o pedido de assistência internacional pode ser remetido ao Ministério da Justiça para, se possível, ser cumprido por outros instrumentos

\footnotetext{
${ }^{437}$ De acordo com a jurisprudência do STJ, haveria duas ordens de cartas rogatórias: a) aquelas relativas a medidas de "mero trâmite ou instrutórias": a concessão de exequatur seria concedida, desde que presentes os pressupostos formais e materiais, independentemente da autoridade que tivesse feito o pedido (se judicial, administrativa, policial ou ministerial). Isso porque tais medidas dispensam deferimento judicial à luz do direito pátrio; b) aquelas cujo objeto são medidas constritivas de direitos individuais da pessoa ofendida (medidas cautelares patrimoniais, buscas e apreensões e afastamento de sigilo): a concessão de exequatur está sujeita à previa decisão estrangeira emanada exclusivamente do Poder Judiciário do estado requerente. ARAÚJO, Nádia de (Coord.). Cooperação jurídica internacional no Superior Tribunal de Justiça: comentários à Resolução nº 9/2005, cit., p. 86-87.

${ }^{438}$ VERGUEIRO, Luiz Fabricio Thaumaturgo. Apontamentos gerais sobre a cooperação jurídica internacional e suas modalidades, cit., p. 405.

439 ABADE, Denise Neves. Direitos fundamentais na cooperação jurídica internacional: extradição, assistência jurídica, execução de sentença estrangeira e transferência de presos, cit., p. 313-314.

${ }^{440}$ VERGUEIRO, Luiz Fabricio Thaumaturgo. Apontamentos gerais sobre a cooperação jurídica internacional e suas modalidades, cit., p. 406.

${ }^{441}$ ABADE, Denise Neves. Direitos fundamentais na cooperação jurídica internacional: extradição, assistência jurídica, execução de sentença estrangeira e transferência de presos, cit., p. 313-314.

${ }^{442}$ DIPP, Gilson. Cartas rogatórias e cooperação jurídica internacional, cit., p. 31.
} 
de cooperação, como o auxílio direto, como disciplina o artigo $7^{\circ}$, parágrafo único, da Resolução 9/2005, do STJ 443444.

O procedimento da carta rogatória está disciplinado na Resolução n. 9/2005 do STJ. Na carta rogatória passiva, submetido ao juízo de admissibilidade administrativo pelo Ministério da Justiça, o pedido é remetido ao Superior Tribunal de Justiça, que determinará a citação da parte interessada para apresentar impugnação em 15 dias. A medida solicitada poderá ser concedida inaudita altera pars, se a intimação prévia do concernido puder resultar na ineficácia da diligência, como geralmente acontece com os pedidos de medidas cautelares patrimoniais (art. $8^{\circ}$, do RSTJ $9^{\circ}$ ). Neste caso, o contraditório será diferido ${ }^{445}$.

A impugnação da carta rogatória é de contenciosidade limitada. Como matéria de defesa, cabe alegar aspectos relativos à autenticidade dos documentos, à inteligência da decisão, ofensa à ordem pública e aos bons costumes ou à inobservância dos requisitos da Resolução (art. $\left.9^{\circ}, \mathrm{RSTJ}\right)$. Após, será dada vista ao Ministério Público, que também poderá propor impugnação no prazo de 10 dias.

Se não houver impugnação pela parte interessada nem pelo Ministério Público, o pedido será decidido pelo Presidente. Da decisão, caberá agravo regimental (art. 11, RSTJ $\mathrm{n}^{\mathrm{o}}$ 9). Se houver impugnação, e se o pedido não for indeferido monocraticamente, os autos serão submetidos a julgamento pela Corte Especial, por

\footnotetext{
${ }^{443}$ Eis o inteiro teor: "os pedidos de Cooperação Jurídica Internacional que tiverem por objeto atos que não ensejem juízo de delibação pelo Superior Tribunal de Justiça, ainda que denominados como carta rogatória, serão encaminhados ou devolvidos ao Ministério da Justiça para as providências necessárias ao cumprimento por auxílio direto".

${ }^{444}$ Esse entendimento ficou evidente na CR 3.462/2009, na qual o Presidente do STJ César Asfor Rocha entendeu que o pedido da promotoria de Frankfurt consistiria em simples notitia criminis, não havendo elementos para a delibação daquela Corte. Por isso, remeteu o caso para o Ministério da Justiça, para as providências cabíveis: “A Promotoria Pública de Frankfurt, República Federal da Alemanha, solicita, nesta rogatória, a instauração no Brasil de procedimento investigativo para apurar esquema internacional organizado por $\mathrm{W}$ G e outro para o cometimento do crime de lavagem de dinheiro, previsto no ordenamento brasileiro pelo art. $1^{\circ}$ da Lei n. 9.613/1998. A investigação objetiva esclarecer o crime antecedente à lavagem de dinheiro e as razões para a transferência dos fundos ao território brasileiro, incluindo, para tanto, a possível quebra de sigilos bancário e fiscal dos envolvidos. Após a análise dos autos verifico que o caso cuida de verdadeira notitia criminis, pela qual se solicita à Justiça brasileira a verificação de eventual iter criminis realizado no Brasil e compartilhamento dos resultados da investigação com a Justiça alemã. Não se vislumbra, portanto, a existência de juízo delibatório a ser exercido por esta Corte, elemento característico à concessão do exequatur nas cartas rogatórias. À vista do exposto, nos termos do previsto no art. $7^{\circ}$ da Resolução n. 9/2005 deste Tribunal, determino a remessa do pedido de cooperação jurídica ao Ministério da Justiça, para a instauração dos procedimentos investigativos cabíveis." (SUPERIOR TRIBUNAL DE JUSTIÇA. Disponível em: <www.stj.jus.br>. Acesso em: 07 set. 2013).

${ }^{445}$ O STF firmou o entendimento de que a concessão de medidas cautelares sem prévia citação da parte interessada não viola a ampla defesa nem o contraditório, que é exercido de forma diferida, por meio de agravo ou embargos (HC 89.555, 2006; HC 89.649, 2007; HC 89.651, 2007; HC 90.485-8, 2007).
} 
determinação do Presidente ${ }^{446}$. Da decisão do órgão especial, caberá somente agravo de instrumento (o STF tem aceitado ordem de habeas corpus impetrados contra decisão do STJ concessiva do exequatur).

Concedido o exequatur, a carta rogatória será remetida ao Juízo Federal competente para cumprimento (artigo 109, X, CF; artigo 13, RSTJ no 9). Aos atos do Juiz no cumprimento da carta rogatória, caberão embargos no prazo de 10 dias, que serão julgados pelo presidente. Da decisão que julgar os embargos, caberá agravo regimental. Cumprida a carta rogatória, está será devolvida ao Presidente do STJ no prazo de 10 dias e, por meio do Ministério da Justiça ou das Relações Exteriores, ao país de origem.

Já na carta rogatória ativa, o procedimento consiste na emissão do pedido de assistência mútua pela autoridade brasileira à Autoridade Central brasileira (DRCI), que, se preenchidos os requisitos de admissibilidade, encaminhará o pedido à Autoridade Central do Estado rogado, se houver tratado internacional com o Brasil, ou, na ausência de tratado, ao Ministério das Relações Exteriores, para encaminhamento pela via diplomática.

Importante observar no procedimento da carta rogatória passiva que a pessoa atingida, muitas vezes, tem sua defesa cerceada em relação ao mérito da decisão estrangeira, que, excepcionalmente, pode ser analisada pelo Superior Tribunal de Justiça, ainda assim, com limitações. No caso de medidas cautelares patrimoniais cumpridas em assistência judicial, esta contenciosidade limitada da carta rogatória restringe a incidência dos direitos fundamentais do concernido, impedindo que este discuta, por exemplo, com o objetivo de evitar a constrição indevida de seu direito constitucional à propriedade privada, a origem lícita dos bens objeto de bloqueio cautelar ou mesmo o limite do valor dos bens a serem bloqueados mediante assistência internacional ${ }^{447}$.

\footnotetext{
${ }^{446}$ Sendo revel o acusado, ser-lhe-á nomeado curador especial. O STF entendia que a nomeação do curador servia para garantir o direito à defesa da parte atingida. Porém, o curador não precisava apresentar contestação, podendo, inclusive, oferecer parecer favorável ao pedido de cooperação. O STJ passou a entender que a nomeação de curador só cabe na homologação de sentença estrangeira, em razão do caráter contencioso daquela medida (AgRg na Pet 5363, 2008).

${ }^{447}$ De fato, como observa DENISE ABADE, “o entendimento majoritário na doutrina brasileira é verdadeira teoria de 'não indagação' mitigada, segundo a qual os institutos de cooperação jurídica, por tratarem de relação entre Estados e não entre indivíduos, são atos do Poder Executivo e como tais devem obedecer somente a regras previstas nos tratados ou nas leis brasileiras". Neste sentido, a adoção do juízo de delibação na apreciação dos pleitos cooperacionais reflete a consagração da teoria do "non-inquiry mitigado", que consiste no "reconhecimento da incidência dos direitos fundamentais no pleito cooperacional, desde que previstos em tratado cooperacional ou lei geral de cooperação". Consequentemente, os direitos fundamentais da pessoa atingida acabam incidindo somente de maneira indireta (Direitos fundamentais na cooperação jurídica internacional: extradição, assistência jurídica, execução de sentença estrangeira e transferência de presos, cit., p. 96-98).
} 
A competência constitucional auferida ao Superior Tribunal de Justiça para o juízo de delibação às solicitações estrangeiras - pelo menos na maneira como tem sido interpretada pela jurisprudência daquela Corte - reduz o procedimento para concessão de exequatur a meras chancelarias. Embora a porta de entrada mais frequente dos direitos fundamentais nos tratados internacionais ainda seja a cláusula de ordem pública ${ }^{448}$, a incidência desta cláusula em defesa do concernido no procedimento da carta rogatória é mediata, incipiente, para não dizer remota.

\subsubsection{Auxílio Direto}

No final dos anos 90, surge um novo instrumento de cooperação denominado "auxílio direto", em face da ratificação brasileira de inúmeros tratados internacionais de assistência jurídica em matéria penal.

O auxílio direto dá ensejo a um procedimento inteiramente nacional. Consiste na cooperação prestada pela autoridade nacional à demanda externa encaminhada por meio da Autoridade Central brasileira, cujo pedido é concebido e analisado como uma diligência originalmente a cargo da jurisdição nacional ${ }^{449}$. No auxílio direto, o Estado estrangeiro não se porta como Juiz, mas como autoridade administrativa. Assim, não encaminha uma decisão judicial a ser aqui cumprida, mas solicita a assistência jurídica para que, no território nacional, sejam tomadas as providências necessárias à satisfação do pedido ${ }^{450}$.

Caso a providência solicitada em assistência jurídica necessite, conforme a lei do Estado requerido, de decisão judicial, serão tomadas as medidas necessárias à satisfação do pedido pela autoridade competente - no Brasil, pelo Ministério Público Federal nas causas de natureza penal e pela Advocacia Geral da União nas causas cíveis.

DENISE ABADE aponta três características fundamentais da assistência jurídica veiculada em auxílio direto. Primeiro, trata-se de uma demanda internacional da parte de outro Estado, ainda que o pedido seja oriundo do Poder Judiciário. O Estado estrangeiro apresenta-se como sujeito de direito internacional que solicita a cooperação, aceitando que as providências sejam tomadas de acordo com o direito do Estado requerido, inclusive por

\footnotetext{
${ }^{448}$ Cf. ABADE, Denise Neves. Direitos fundamentais na cooperação jurídica internacional: extradição, assistência jurídica, execução de sentença estrangeira e transferência de presos, cit., p. 327.

${ }^{449}$ ARAÚJO, Nádia de (Coord.). Cooperação jurídica internacional no Superior Tribunal de Justiça: comentários à Resolução no 9/2005, cit., p. 94.

${ }^{450}$ DIPP, Gilson. Cartas rogatórias e cooperação jurídica internacional, cit., p. 32.
} 
meio de medidas judiciais internas. Segundo, há cognição plena do pedido do Estado requerente pela autoridade judiciária do Estado requerido. Assim, ao optar pelo auxílio direto, o Estado requerente concorda que a autoridade do Estado requerido analise, à luz de seu ordenamento interno, as razões do pedido. Consequentemente, busca-se produzir uma decisão judicial doméstica que, como tal, não está sujeita ao juízo de delibação do Superior Tribunal de Justiça. Terceiro, o Poder Executivo desempenha papel de destaque no auxílio direto, na medida em que a ele, através da Autoridade Central, incumbe decidir sobre o encaminhamento do pedido de assistência jurídica internacional para o Ministério Público Federal ${ }^{451}$.

Assim, no auxílio direto, o pedido tramita diretamente entre as autoridades centrais, sendo instrumento de assistência mais célere e menos burocrático. O pedido de auxílio direto é fundado em tratado internacional e, excepcionalmente, pode ser cumprido mediante compromisso de reciprocidade. Conforme salienta o Ministro DiAS TÓFFOLI ${ }^{452}$, medidas cautelares patrimoniais, como sequestro de bens ou congelamento de valores bancários, também podem ser objeto do auxílio direto. Nesse caso, "o juiz de primeiro grau que recebe o pedido tem cognição plena para apreciá-lo, estabelecendo contraditório para centralizar seu livre convencimento".

Vale lembrar que o auxílio direto ganhou terreno como solução à proibição de cumprimento de cartas rogatórias com caráter executório, mantida por muito tempo pelo Supremo Tribunal Federal quando tinha competência para a concessão de exequatur às cartas rogatórias passivas.

Prevê a Resolução n 9/2005, art. 7º, parágrafo único, do STJ que “os pedidos de cooperação jurídica internacional que tiverem por objeto atos que não ensejem juízo de delibação pelo Superior Tribunal de Justiça, ainda que denominados como carta rogatória, serão encaminhados ou devolvidos ao Ministério da Justiça para as providências necessárias para o cumprimento por auxílio direto". Assim, o pedido de assistência que tenha por objeto, por exemplo, a constrição de bens, direitos e valores oriundos da prática

\footnotetext{
${ }^{451}$ A bem da verdade, a Autoridade Central também faz importante controle prévio de admissibilidade administrativo na carta rogatória, decidindo os casos que devem ou não ser encaminhados ao STJ para delibação. A diferença é que os casos encaminhados ao Parquet federal como auxílio direto passarão por uma análise, seja por este órgão - quanto à legalidade e pertinência da medida -, seja pelo Juiz Federal competente que julgará a pedida, se proposta, ao passo que, na carta rogatória, o controle é concentrado no Juízo de delibação do STJ, culminando no exequatur.

${ }^{452}$ TOFFOLI, José Antonio Dias; CESTARI, Virgínia Charpinei Junger. Mecanismos da cooperação jurídica internacional no Brasil, cit., p. 27.
} 
de delito no exterior pode ser cumprido pelo Estado brasileiro via carta rogatória ou auxílio direto, a depender da necessidade de juízo de delibação pelo STJ.

Explica-se: havendo decisão emanada da autoridade estrangeira a ser sujeita ao juízo de delibação pelo Superior Tribunal de Justiça, ao chegar à Autoridade Central brasileira, o pedido será processado como carta rogatória, sendo cumprido pelo Juiz Federal competente após a concessão de exequatur. Por outro lado, se não houver decisão estrangeira a ser delibada, e havendo tratado internacional, o pedido poderá ser cumprido no Brasil por auxílio direto, ainda que tenha sido denominada carta rogatória. Neste caso, a medida cautelar patrimonial será requerida pelo Ministério Público Federal perante o Juiz Federal da Subseção Judiciária competente, processando-se o pedido como se nacional fosse, com base nos documentos e dados fornecidos pela autoridade do Estado requerente, de acordo com o direito do Estado requerido e através de medidas judiciais internas.

Há verdadeiro deserto normativo quanto à possibilidade de aplicação do auxílio direto. D'outro vértice, houve sensível resistência do Supremo Tribunal Federal e do Superior Tribunal de Justiça em aceitar a possibilidade de atendimento de pedidos de assistência jurídica internacional - inclusive de medidas cautelares patrimoniais - pela via do auxílio direto.

No auxílio direto, não vemos óbice para que o controle do Estado brasileiro sobre o pedido da autoridade estrangeira seja feito de forma difusa, diretamente pelo Juiz Federal de primeira instância. Afinal, através desta modalidade de assistência jurídica, mediante a provocação do Estado estrangeiro e por iniciativa do Parquet federal, busca-se uma decisão doméstica de acordo com o direito pátrio, estando a ela sujeitos todos os recursos legais cabíveis.

O controle difuso do Superior Tribunal de Justiça das decisões obtidas em primeira instância, em decorrência de auxílio direto, poderia ser realizado, ainda, pela criação de uma nova modalidade recursal, cabível em circunstâncias específicas, semelhante aos embargos previstos na Resolução ${ }^{\circ}$ 9, do STJ contra ato do juiz durante o cumprimento da ordem de exequatur na carta rogatória.

A nosso ver, trata-se, por um lado, de procedimento de cooperação mais célere e menos burocrático ${ }^{453}$. O auxílio direto permite maior controle do ato solicitado pela

\footnotetext{
${ }^{453} \mathrm{O}$ auxílio direto é sem sombra de dúvidas menos burocrático, na medida em que o pedido tramita diretamente entre Autoridades Centrais e não se submete ao prévio juízo de delibação. Ser menos burocrático, contudo, não significa necessariamente ser mais rápido. A nacionalização do pedido permite maior cognição e contenciosidade estendida, cabendo às partes todos os recursos inerentes, e pode levar tempo até que a medida torne-se definitiva para ser devolvida ao Estado requerente.
} 
autoridade requerente e também possibilita ao acusado exercer o contraditório e a ampla defesa com maior amplitude. Como bem observado por DENISE ABADE:

"No que tange à aplicação dos direitos fundamentais na cooperação, vemos que a ressurreição do auxílio direto - quando pensávamos que o instituto havia sido extinto pelas cortes nacionais - faz renascer uma via pela qual os direitos fundamentais previstos no Brasil incidirão diretamente no pleito cooperacional, uma vez que o pedido estrangeiro é, neste caso, mero fundamento de ações internas promovidas pelas autoridades brasileiras competentes, submetidas, é claro, aos direitos fundamentais estatuídos na Constituição e tratados internacionais" ${ }^{454}$.

Em suma, a nosso ver, trata-se o auxílio direto do modelo de assistência jurídica internacional que mais se mostra capaz de associar eficiência aos direitos fundamentais da pessoa atingida.

\subsection{O conflito entre as opções de processo penal: dificuldade no atendimento de medidas cautelares patrimoniais em cooperação jurídica no Brasil}

Ao receber pedido de cooperação jurídica internacional, o judiciário brasileiro deve promover os atos solicitados em assistência mútua em conformidade com o previsto no ordenamento nacional (e deve atender, sempre no que couber, às formalidades sugeridas pela autoridade estrangeira). Paralelamente, o Estado brasileiro deve admitir como válidos os atos processuais realizados no estrangeiro, de acordo com as leis daquela jurisdição $^{455}$. Isto porque, no chamado Direito Processual Internacional, os atos judiciais são regidos pela regra teórica do lex fiori.

Na prática, contudo, o reconhecimento do lex fiori pelo Brasil ainda enfrenta muitos entraves, alguns dos quais aparentemente intransponíveis.

A busca exacerbada de proteção da soberania nacional desemboca, muitas vezes, em verdadeira aversão a qualquer modelo estrangeiro que não se assemelhe à opção brasileira de direito processual penal. Como aponta LuIZ FABrício Thaumaturgo VERGUEIRO, a definição teórica do lex fiori "esbarra em dificuldades quando os atos processuais parecem excessivamente estranhos ao direito brasileiro, em especial no que

\footnotetext{
${ }^{454}$ ABADE, Denise Neves. Direitos fundamentais na cooperação jurídica internacional: extradição, assistência jurídica, execução de sentença estrangeira e transferência de presos, cit., p. 322.

${ }^{455}$ VERGUEIRO, Luiz Fabricio Thaumaturgo. Apontamentos gerais sobre a cooperação jurídica internacional e suas modalidades, cit., p. 395.
} 
tange à competência de órgãos jurisdicionais e de autoridades estrangeiras, problema existente também em outras tradições jurídicas" ${ }^{456}$.

Essa postura, por lógico, impõe-se como barreira ao fluido cooperacional entre o Brasil e os Estados estrangeiros.

Até recentemente, pedidos de assistência jurídica internacional recebidos pelo Estado brasileiro passavam pelo juízo de delibação do Supremo Tribunal Federal.

Viu-se que, ao longo dos anos, o Supremo manteve firme o entendimento de que deveriam ser devolvidos os pedidos de assistência jurídica internacional considerados de "caráter executório", ou seja, que pressupunham o cumprimento, na jurisdição brasileira, de ordem emanada de outra jurisdição. Argumentava-se que a execução, em solo nacional, de medidas decretadas por juiz estrangeiro atentaria contra a ordem pública.

Assim, pelo caráter executório, medidas cautelares patrimoniais solicitadas em cooperação internacional dificilmente recebiam o exequatur. Em várias ocasiões, o Supremo Tribunal Federal sustentou que medidas decretadas no exterior seriam passíveis de execução no Brasil por homologação de sentença estrangeira ${ }^{457}$ - algo impraticável, porque somente decisão judicial estrangeira transitada em julgado era (e ainda é) suscetível a homologação ${ }^{458}$.

Em decorrência desse posicionamento, que, na visão de ANTENOR MADRUGA, colocava a jurisprudência do Supremo Tribunal Federal na Idade Média da cooperação jurídica internacional $^{459}$, por anos o Brasil se recusou a cumprir medidas cautelares cuja

\footnotetext{
${ }^{456}$ VERGUEIRO, Luiz Fabricio Thaumaturgo. Apontamentos gerais sobre a cooperação jurídica internacional e suas modalidades, cit., p. 395.

${ }^{457}$ WEBER, Patrícia Nuñez. A cooperação jurídica internacional em medidas processuais penais, cit., p. 119.

${ }^{458}$ Regimento Interno do Supremo Tribunal Federal, em seu art. 217, previa como requisito essencial à homologação de sentença estrangeira esta ter sido proferida por juiz competente e "ter passado em julgado e estar revestida das formalidades necessárias à execução no lugar em que foi proferida" (art. 217, inc. III). No mesmo sentido, v. art. $5^{\circ}$, inc. III, da Resolução n. 9 do STJ. Nesse sentido, "De fato, ao se exigir sentença estrangeira transitada em julgado para atos constritivos meramente cautelares ou preparatórios, como, por exemplo, a quebra do sigilo bancário brasileiro de alguém processado no exterior, a jurisprudência e doutrina brasileira tornavam quase impossível a persecução criminal estrangeira" (ABADE, Denise Neves. Direitos fundamentais na cooperação jurídica internacional: extradição, assistência jurídica, execução de sentença estrangeira e transferência de presos, cit., p. 332).

459 "Daqui a alguns anos olharemos para trás e escreveremos sobre uma sociedade que vivia em feudos jurídicos. Falaremos de um tempo em que juízes se comunicavam por cartas, enviadas por via aérea e terrestre, confirmadas, uma a uma, pelo Supremo Tribunal Federal. Lembraremos da época em que fronteiras facilitavam o crime e dificultavam a prestação de alimentos. Não nos faltará a memória desse tempo em que promotores de justiça desistiam de promover a justiça quando esta se encontrava distante dos promotores de justiça. Assim como os progressos da atrelagem de carros de boi e da navegação a partir do Século X contribuíram para ampliar o comércio interfeudal, aproximar os povos e apressar o fim da Primeira Idade Média, a nova revolução dos transportes e na comunicação - gestora de uma mesma
} 
finalidade fosse bloquear bens ou valores existentes no país, com o objetivo de assegurar a eficiência e utilidade da condenação penal em processo estrangeiro.

Juízes e tribunais brasileiros viram-se diante da necessidade de solicitar auxílio internacional para, em território de país estrangeiro, dar eficácia a medidas essenciais a processos sub-judice. Contraditoriamente, porém, ganharam notoriedade casos em que medidas cautelares patrimoniais penais solicitadas pelo Brasil foram atendidas no exterior, ao passo que, no Brasil, idêntico pedido, e pior, do mesmo país estrangeiro foi negado pelo Supremo Tribunal Federal. Situação, no mínimo, embaraçosa.

Talvez o mais famoso desses casos, citado por MADRUGA ${ }^{460}$, diga respeito a um pedido de assistência jurídica internacional feito por juiz federal brasileiro ao Estado da Alemanha, para que tivesse acesso a documentos bancários que seriam usados como prova em ação penal instaurada por lavagem de dinheiro, solicitando, ainda, o bloqueio cautelar dos fundos depositados em conta corrente mantida em instituição bancária daquele país.

A autoridade judiciária alemã atendeu ao pedido e determinou o bloqueio dos ativos indicados pelo juiz federal brasileiro. Em contrapartida, aquela mesma autoridade, usando idêntica via cooperacional (carta rogatória), pediu ao Brasil documentos indicativos da titularidade da conta objeto do bloqueio, a fim de investigar a ocorrência de eventual crime de lavagem de dinheiro na Alemanha. O pedido da autoridade judicial alemã chegou ao Supremo Tribunal Federal e foi rechaçado monocraticamente pelo Ministro Relator por despacho padrão, com base no famigerado argumento de que "a quebra de sigilo de dados, na carta rogatória, alcança contornos executórios, o que inviabiliza a pretendida concessão de exequatur" ${ }^{\text {"461 }}$.

Definitivamente, essa postura refratária aos Estados estrangeiros movimentou o Brasil na contramão do processo evolutivo cooperacional e o colocou diante de situação

economia global sem precedentes - inexoravelmente nos levará ao fim desta Segunda Idade Média em que vivemos" (MADRUGA, Antenor. O Brasil e a jurisprudência do STF na Idade Média da cooperação jurídica internacional, cit., p. 77).

${ }^{460}$ MADRUGA, Antenor. O Brasil e a jurisprudência do STF na Idade Média da cooperação jurídica internacional, cit., p. 88-89.

461“Por outro lado, conforme consta à fl. 187, 'a exordial acusatória faz menção a valores de movimentação financeira, a números de contas bancárias e a comunicações telefônicas interceptadas que, ao menos em tese, consubstanciam informações acobertadas por sigilo, nos termos do artigo 3o da Lei n. ${ }^{\circ} 9034 / 95$ e do artigo 8 o da Lei n. ${ }^{\circ}$ 9296/96'. 12. Assim sendo, esta Corte firmou entendimento de que a quebra de sigilo de dados, na carta rogatória, alcança contornos executórios, o que inviabiliza a pretendida concessão de exequatur. Nesse sentido CRs 6779 e 6681, Octavio Gallotti, DJU de 13.03.95 e 06.04.95 respectivamente e 8622, Velloso, DJU de 05.10.99”' (STF, CR-10.692. Rel. Min. Maurício Corrêa, decisão monocrática proferida em 01/08/2003). 
constrangedora perante a comunidade internacional, uma vez avesso o Judiciário brasileiro a proporcionar efetiva prestação jurisdicional em auxílio mútuo.

Sensível ao problema, NÁDIA ARAÚJo há muito defendia a necessidade de uma revisão no entendimento do Supremo Tribunal Federal:

"A questão do indeferimento por contrariedade à ordem pública das decisões de caráter executório também necessitava de revisão urgente, especialmente depois que o STF passou a aceitar essas medidas se decorrentes de tratado. Se para os países com os quais nos associamos, a oposição à ordem pública per se não mais se sustentava, ficou difícil aceitá-la sem maiores indagações nos demais casos. Ademais, essa posição estava colocando o país em posição delicada, já que os pedidos do Brasil, por exemplo, nos casos de quebra de sigilo bancário no exterior e posterior repatriamento de divisas tem sido aceito rotineiramente, enquanto o STF os recusava" ${ }^{462}$.

MAÍRA RoCHA MACHADO publicou relevante estudo ${ }^{463}$ no qual analisa 400 pedidos de cooperação jurídica internacional em matéria penal decididos pelo Supremo Tribunal Federal entre 1994 e 2004. Dos pedidos analisados, 20 referiam-se a medidas cautelares, e destes o STF concedeu exequatur a somente 3, negando os demais.

A autora contabilizou seis argumentos mais utilizados para a denegação dos pedidos de auxílio internacional: a) caráter executório; b) necessidade de homologação de sentença estrangeira; c) necessidade de procedimento judicial; d) atentado à soberania, e) atendado à ordem pública e f) ausência ou insuficiência de provas ${ }^{464}$.

Dos três casos analisados por MACHADO em que o exequatur foi concedido, o Supremo Tribunal Federal levantou dois argumentos: primeiro, existia acordo internacional firmado entre o Brasil e o Estado requerente; segundo, a solicitação partira de autoridade judicial estrangeira.

Destaquemos o segundo argumento, de que a solicitação partira de autoridade judicial. Tratava-se de pedido de cooperação jurídica internacional recebido do Chile para

\footnotetext{
${ }^{462}$ ARAÚJO, Nádia de. As novidades da Resolução n. 9 do STJ, que dispõe sobre cartas rogatórias e sentenças estrangeiras. Disponível em: <http://www.dip.com.br>. Acesso em: jul. 2012.

${ }^{463}$ MACHADO, Maíra Rocha. Cooperação penal internacional e o intercâmbio de informações bancárias: as decisões do STF sobre quebra de sigilo em cartas rogatórias. In: MACHADO, Maíra Rocha; REFINETTI, Domingos Fernando (Orgs.). Lavagem de dinheiro e recuperação de ativos: Brasil, Nigéria, Reino Unido e Suíça. São Paulo: Quartier Latin, 2006.

${ }^{464}$ MACHADO, Maíra Rocha. Cooperação penal internacional e o intercâmbio de informações bancárias: as decisões do STF sobre quebra de sigilo em cartas rogatórias, cit., p. 105.
} 
a quebra de sigilo bancário e fiscal de membros de uma quadrilha voltada ao tráfico internacional de entorpecentes ${ }^{465}$.

Neste caso, a similitude dos procedimentos chileno e brasileiro no que toca à reserva de jurisdição para ao afastamento do sigilo foi o que orientou o Supremo pela concessão do exequatur. Como o pedido provinha de autoridade judicial chilena, em semelhante "teor da legislação brasileira que veda o fornecimento de informações senão por força de determinação e/ou requerimento judicial”, concluíram os Ministros que, ao atender ao pedido do Chile, não "se estaria ferindo qualquer preceito legal vigente no ordenamento jurídico pátrio" 466 .

Ora, muito oportuna é a indagação suscitada por MACHADO: "pode-se extrair desta decisão - e das outras indicando que a ausência de decisão judicial no país que solicita a medida impede a concessão do exequatur - a existência de um entendimento segundo o qual os procedimentos devem ser idênticos, no país solicitante e no país solicitado, para que este possa dar cumprimento a determinada medida?"467.

Entendemos que a resposta deveria ser positiva. O cerne do problema parece estar mesmo no conflito que surge a partir das diferentes opções de processo penal.

A jurisprudência do Supremo Tribunal Federal se pautou quase exclusivamente nas diferenças entre o sistema jurídico interno e as opções processuais penais dos Estados estrangeiros requerentes de medidas cautelares penais em cooperação.

Envolvido por uma visão que não se põe a enxergar nada além-fronteiras ${ }^{468}$, o STF adota postura soberanista e refratária, que desconfia e rejeita o modelo processual alheio em tudo o que lhe opõe, como se não pudesse haver qualquer liame apesar das diversidades. Não bastaria a equivalência de medidas previstas em ambos os países ${ }^{469}$. O

\footnotetext{
${ }^{465}$ STF, CR-99.388/Chile, rel. Min. Carlos Velloso, DJ 13.02.2001.

466“"Em se tratando de quebra de sigilo fiscal e bancário, certo é que somente por intermédio de decisão judicial estas medidas poderiam ser levadas a efeito, a teor da legislação brasileira que veda o fornecimento de informações senão por força de determinação e/ou requerimento judicial. Como, no caso, trata-se de pedido judicial, a ser convalidado pela mais alta Corte de Justiça brasileira, ou seja, o E. STF, nada obsta, ao ver do MPF, a concessão do exequatur, posto que não se estaria ferindo qualquer preceito legal vigente no ordenamento jurídico pátrio" (STF, CR-99.388/Chile, rel. Min. Carlos Velloso, DJ 13.02.2001).

${ }^{467}$ MACHADO, Maíra Rocha. Cooperação penal internacional e o intercâmbio de informações bancárias: as decisões do STF sobre quebra de sigilo em cartas rogatórias, cit., p. 112.

${ }^{468}$ Visão esta chamada por parcela da doutrina como "xenofobia judiciária" (v. MADRUGA, Antenor. O Brasil e a jurisprudência do STF na Idade Média da cooperação jurídica internacional, cit., p. 82; ABADE, Denise Neves. Direitos fundamentais na cooperação jurídica internacional: extradição, assistência jurídica, execução de sentença estrangeira e transferência de presos, cit., p. 333).

${ }^{469}$ Manifestações em sentido contrário são encontradas em alguns poucos precedentes do Supremo Tribunal
} 
devido processo brasileiro deveria ser seguido cabalmente, sob pena de indeferimento da medida cautelar solicitada, pouco importando as opções diferenciadas do ordenamento do Estado requerente $^{470}$.

Aceitando cooperar somente com países que tivessem semelhante opção de tutela cautelar penal, na prática, o Brasil pouco cooperava. E é fácil entender o porquê. DENISE NEVES ABADE explica ser quase letal à cooperação jurídica internacional pressupor que a integralidade do modelo brasileiro de persecução penal deva ser obedecida por todos os países com os quais o país coopere. Para a autora, exigência como essa "fulmina a cooperação em matéria penal, porque é óbvio que nenhum país possui perfeitamente o mesmo modelo de persecução criminal de outro, sem contar que dificilmente seria possível adaptar o seu modelo aos parâmetros exigidos pelo STF",471.

Assim, a pretensa proteção da ordem pública, a negativa de cumprir pedidos de caráter executório e outros argumentos mais não passariam de mera falácia, pois não se sustentam. "Essa visão, em que pese seu fundamento de proteção a direitos fundamentais, era baseada em indisfarçável desejo de dificultar a constrição ou restrição de direitos no Brasil fundada em ordem estrangeira, o que denota claro preconceito ${ }^{\text {,472. }}$.

Consequentemente, observa MADRUGA, dada a desconfiança em relação às decisões judiciais estrangeiras, em especial nas medidas cautelares patrimoniais penais, "Paradoxalmente, a cooperação internacional para a extradição de pessoas é muito mais fluida que a cooperação internacional para quebra de sigilos legais e outras medidas restritivas de direitos". Nesse contexto, "é mais fácil, no "âmbito da cooperação jurídica

Federal, porém em pedidos de extradição: “(...) é de se atentar para que os sistema processual da Suíça, como na França, não é idêntico ao brasileiro. Adota-se naqueles países uma instrução preparatória e obrigatória em matéria de crime, confiada ao juiz de instrução, sob o controle de tribunal de acusação. (...) não podemos ditar regras ao direito alienígena, como se estivéssemos tratando exatamente da nossa prisão preventiva. Basta-nos a equivalência das medidas previstas em ambos os países" (Extradição n. 336, Requerente: Governo da Suíça, Extraditando: Raphael Fratola, j. 18.05.1977, p. DJ 09.08.1977). Este precedente foi citado depois na Extradição n. 504, Requerente: Governo da Suíça, Extraditando: Hermann Max Fehr, j. 19.02.1990, DJ 29.06.1990.

${ }^{470}$ ABADE, Denise Neves. Direitos fundamentais na cooperação jurídica internacional: extradição, assistência jurídica, execução de sentença estrangeira e transferência de presos, cit., p. 348.

${ }^{471}$ ABADE, Denise Neves. Direitos fundamentais na cooperação jurídica internacional: extradição, assistência jurídica, execução de sentença estrangeira e transferência de presos, cit., p. 349.

${ }^{472}$ ABADE, Denise Neves. Direitos fundamentais na cooperação jurídica internacional: extradição, assistência jurídica, execução de sentença estrangeira e transferência de presos, cit., p. 279. Segundo a autora, no Brasil, "A assistência jurídica internacional nasce, como qualquer outra espécie da cooperação jurídica internacional em matéria penal, sob o signo da necessidade e da desconfiança. Necessidade, porque o Brasil, desde a independência, percebeu a urgência na colaboração com Estados estrangeiros em matéria penal, pois o crime não obedece a fronteiras políticas. Desconfiança, pois a execução sem restrições de atos de jurisdição estrangeira em território nacional ofenderia a soberania brasileira" (op. cit., p. 309). 
internacional, entregar a liberdade de uma pessoa que fornecer seus dados bancários ou disponibilizar seus bens" ${ }^{473}$.

Com a entrada em vigor da Emenda Constitucional n. 45/2004, a competência para a concessão de exequatur foi deslocada para o Superior Tribunal de Justiça. Assim, o STJ passou a ser competente para processar e julgar os pedidos de cooperação jurídica internacional, com exceção das matérias relativas à extradição, que permaneceram na competência do Supremo Tribunal Federal.

Em 4 de maio de 2005, o Superior Tribunal de Justiça editou a Resolução n. 9. O principal destaque dessa resolução está na aparente tentativa de dar maior eficiência à cooperação jurídica internacional, possibilitando o cumprimento de medidas solicitadas, ainda que tenham caráter executório ${ }^{474}$.

O Superior Tribunal de Justiça, aos poucos, tem revertido a orientação até então sustentada com braços de ferro pelo Supremo e aplicado, em casos pontuais, o princípio da equivalência (lex loci regit actum), previsto em alguns tratados firmados pelo Brasil $^{475}$. Por esse princípio, aceita-se que o ordenamento do Estado requerente regule a competência das autoridades que podem adotar medidas e requerer a cooperação ${ }^{476}$. Assim, buscando respeitar a diversidade de cada sistema jurídico e evitar conflitos, o princípio da equivalência impede que a legislação brasileira imponha o critério de legitimação da autoridade estrangeira $^{477}$.

Entretanto, malgrado a crítica da doutrina, em alguns casos o Superior Tribunal de Justiça reproduz idêntica premissa do Supremo Tribunal Federal no sentido de que a

\footnotetext{
${ }^{473}$ MADRUGA, Antenor. O Brasil e a jurisprudência do STF na Idade Média da cooperação jurídica internacional, cit., p. 82.

474“"Art. $7^{\circ}$. As cartas rogatórias podem ter por objeto atos decisórios ou não decisórios”.

${ }^{475}$ Conforme art. $4^{\circ}$, da Convenção Interamericana sobre Assistência Mútua em Matéria Penal (Decreto n. 6.340, de 3 de janeiro de 2008), "A assistência a que se refere a presente Convenção, levando em conta a diversidade dos sistemas jurídicos dos Estados Partes, basear-se-á em pedidos de cooperação das autoridades encarregadas da investigação ou do julgamento de delitos no Estado requerente".

${ }^{476}$ Como se verifica no HC 90.485 do STF, rel. Min. Cezar Peluso, DJU 08.06.2007. Recentemente, decidiu o Superior Tribunal de Justiça: "Não ofende a ordem jurídica nacional a concessão de exequatur às cartas rogatórias originadas de autoridade estrangeira competente de acordo com a legislação local, mesmo que não integrada ao Judiciário, se transmitidas via diplomática ou pelas autoridades centrais e em respeito aos tratados de cooperação jurídica internacionais” (STJ, AgRg na CR 5.694/PT, rel. Min. Félix Fischer, j. 17.04.2013).

${ }^{477}$ BECHARA, Fábio Ramazzini; ARAÚJO, Marcilândia. Medidas de cooperação reais, cit., p. 497.
} 
integralidade do modelo brasileiro de persecução penal deve ser obedecida por todos os países com os quais o país coopera ${ }^{478}$.

A título de exemplo, no ano de 2007, o Superior Tribunal de Justiça interpretou inclusive a legislação italiana para concluir que, no caso de sequestro de valores, "o Ministério Público italiano não tem competência para determinar a quebra de sigilo bancário ou sequestro de valores, tanto na Itália, quanto no Brasil: tal atribuição é privativa de juiz. - O sequestro de valores depositados em contas correntes no Brasil depende de sentença, previamente homologada pela justiça brasileira que o decrete" ${ }^{479}$.

Assim como o Supremo Tribunal Federal fazia, o Superior Tribunal de Justiça continua exigindo o respeito ao modelo brasileiro relativo ao bloqueio cautelar de bens ${ }^{480}$. Se no modelo brasileiro se exige que a restrição ao direito de propriedade parta de decisão de autoridade judicial, a mesma exigência é transporta aos ordenamentos estrangeiros.

O judiciário brasileiro desperdiça a rara oportunidade de abrir seus horizontes à cooperação jurídica e permitir o trânsito cooperacional suficientemente fluido e eficiente o que não significa menos garantista, a despeito da diversidade de sistemas jurídicos, se considerarmos os países com os quais o Brasil se compromete a cooperar.

Fundamental observar o caráter inovador do Protocolo de Assistência Jurídica Mútua em Assuntos Penais para o Mercosul $^{481}$ quando reconhece a diversidade dos sistemas jurídicos dos Estados-partes. Prevê o art. $4^{\circ}$ que as solicitações de assistência se basearão em "pedidos de assistência de autoridades judiciais ou do Ministério Público do Estado requerente encarregado do ajuizamento ou investigação dos delitos".

\footnotetext{
${ }^{478}$ Entretanto, o Superior Tribunal de Justiça decidiu não ser possível a realização de sequestro de bens em cooperação jurídica internacional quando ausente uma decisão judicial estrangeira (CR 998/IT, rel. Min. Edson Vidigal, DJ de 30/04/2007 e CR 3162/CH, rel. Min. Cezar Asfor Rocha, DJe de 06/09/2010).

${ }^{479}$ STJ, AgRg na CR 998/IT, rel. Min. Humberto Gomes de Barros, DJU de 30-4-2007. Segue a ementa: “AGRAVO REGIMENTAL. CARTA ROGATÓRIA. COOPERAÇÃO JURÍDICA. BRASIL. ITÁLIA. DILIGÊNCIAS. VÍCIOS FORMAIS. INEXISTENTES. QUEBRA SIGILO BANCÁRIO. SOBERANIA. ORDEM PÚBLICA. PARCIAL PROVIMENTO.

- No Direito italiano a Magistratura e o Ministério Público convivem em uma só estrutura administrativa.

- A Procuradoria da República junto ao Tribunal de Parma tem legitimidade para solicitar cooperação brasileira em investigações.

- O Ministério Público Italiano não tem competência para determinar a quebra de sigilo bancário ou sequestro de valores, tanto na Itália, como no Brasil: tal atribuição é privativa de juiz.

- O sequestro de valores depositados em contas correntes no Brasil depende de sentença, previamente homologada pela Justiça brasileira, que o decrete".

${ }^{480}$ ABADE, Denise Neves. Direitos fundamentais na cooperação jurídica internacional: extradição, assistência jurídica, execução de sentença estrangeira e transferência de presos, cit., p. 341.

${ }^{481}$ Decreto n. 3.468, de 27 de maio de 2000.
} 
Com muita precisão, aponta RAÚL CERVINI que o Protocolo se preocupa que, "sem alterar as formas do devido processo que marca a lei interna de cada país, por sua flexibilidade, coloque os Estados em insuperáveis condições de acordar com países integrantes da comunidade e eventualmente com outros extracomunitários pertencentes a diferentes sistemas jurídicos, uma eficaz rede de tratados de assistência jurídica penal”482.

Mesmo adstrito aos Estados-partes integrantes do Mercosul, o Protocolo pode servir como importante referência a futuros acordos internacionais a serem firmados entre o Brasil e os países extracomunitários, sobretudo no que se refere ao reconhecimento da diversidade de sistemas processuais, a assegurar, desse modo, uma maior permeabilidade e flexibilidade ao atendimento de pedidos de auxílio mútuo.

${ }^{482}$ CERVINI, Raul; TAVARES, Juarez. Princípios da cooperação judicial penal internacional no Protocolo do Mercosul, cit., p. 115. 


\section{MEDIDAS CAUTELARES PATRIMONIAIS EM COOPERAÇÃO JURÍDICA INTERNACIONAL: QUESTÕES PONTUAIS}

\subsection{Aspectos introdutórios}

Nos capítulos anteriores, estudamos a cooperação jurídica internacional sob a perspectiva de um processo, o chamado processo cooperacional. Ainda tratamos das medidas cautelares patrimoniais penais, contextualizando-as no cenário da cooperação.

O objetivo deste último capítulo será identificar alguns conflitos - aqueles elencamos como principais - decorrentes do cumprimento de medidas cautelares através da cooperação internacional, nas modalidades da carta rogatória e do auxílio direto $^{483}$. As questões a serem enfrentadas neste capítulo não excluem a possível coexistência de outros aspectos igualmente relevantes a respeito do mesmo tema, mas que não poderão ser comtemplados.

Por opção metodológica, dividiremos as questões em três temas fundamentais: legalidade, legitimidade e participação do concernido.

Importante salientar, por fim, que o presente capítulo não será dedicado à sistematização nem ao aprofundamento doutrinário das medidas cautelares patrimoniais em cooperação jurídica. Tampouco se pretende apontar soluções a todas as questões debatidas neste capítulo, porque demandaria aprofundamento de outros temas de direito processual penal, fugindo da proposta inicialmente traçada: estudar a cooperação jurídica internacional na visão de um processo, com foco nas cautelares patrimoniais penais.

\footnotetext{
${ }^{483}$ Carta rogatória e auxílio direto são as modalidades de cooperação jurídica internacional adequadas ao cumprimento de atos judiciais no exterior, no caso, ao cumprimento de medidas cautelares patrimoniais. Por isso, a despeito de existirem outros mecanismos de cooperação internacional, trataremos neste capítulo apenas dos aspectos relacionados à carta rogatória e ao auxílio direto.
} 


\subsection{Legalidade}

\subsubsection{Autonomia do processo cautelar e o processo estrangeiro}

Consoante já demonstrado, existe discussão doutrinária sobre a existência de autonomia do processo cautelar penal, e mesmo sobre a existência de ação cautelar autônoma de natureza penal, semelhante a ação cautelar de natureza civil ${ }^{484}$.

Mesmo quem defende a autonomia do processo cautelar na esfera penal, do que discordamos - defendemos que as medidas cautelares patrimoniais sejam exercidas através de simples medidas incidentais, e não propriamente por uma ação ou processo cautelar autônomo -, essa autonomia do processo cautelar seria relativa, pois a tendência é vincular o processo cautelar a outro processo, o processo principal, sendo que este justifica a existência daquele ${ }^{485}$.

$\mathrm{Na}$ cooperação jurídica internacional, tratando-se de carta rogatória passiva, os documentos que instruem o pedido de assistência, se suficientes, dão lastro ao juízo de delibação no que diz ao respeito à ordem pública e ao cumprimento dos requisitos formais estabelecidos em tratado - frise-se: carta rogatória é instrumento que não permite cognição plena. Por outro lado, de acordo com a regra do locus regit actum, pedidos de assistência costumam ser processados, cumpridos e devolvidos ao Estado requerente, independentemente do trâmite do processo estrangeiro que o origine.

Situação semelhante ocorre no auxílio direto, em que a medida é proposta, analisada e decidida pela autoridade do Estado requerido, com cognição plena.

É de se questionar, portanto, se a tutela cautelar no contexto da cooperação jurídica internacional seria exercida mediante simples medidas incidentais. Medidas cautelares patrimoniais são instrumentalizadas no âmbito interno por meio do processo cooperacional, que se reveste de aparente autonomia em relação ao processo estrangeiro: parte de um pedido inicial de assistência mútua, para ser decidido pela autoridade competente do Estado requerido, cumprido e, ao final, devolvido ao país de origem.

\footnotetext{
${ }^{484}$ V. Capítulo II, item 2.4.1, relativo às medidas cautelares patrimoniais penais no Brasil.

${ }^{485}$ Neste sentido, afirma ANTONIO SCARANCE FERNANDES: "Discute-se sobre a autonomia do processo cautelar: constituiria ele, ou não, um terceiro gênero, ao lado do processo de conhecimento e de execução? A tendência predominante no Brasil é dotar o processo cautelar de autonomia, mas ligando-o a outro processo (de conhecimento ou de execução), que justifica sua existência" (Processo penal constitucional, cit., p. 279).
} 
Entretanto, essa aparente autonomia do processo cooperacional em relação ao processo estrangeiro seria meramente relativa. Como visto, o processo cooperacional não tem um fim em si mesmo, mas se vincula ao processo estrangeiro, assessorando-o, com o objetivo de assegurar-lhe a devida eficácia.

Nesta mesma toada, medida cautelar patrimonial cumprida em assistência internacional também não busca assegurar o processo cooperacional, e, sim, o processo estrangeiro (principal). Ou seja, o processo cooperacional é o instrumento através do qual a medida cautelar patrimonial, cumprida sob a jurisdição do Estado requerido, garante eficácia e utilidade a eventual sentença penal do Estado requerente, no que diz respeito aos efeitos automáticos da condenação.

Assim, nos pedidos de assistência internacional que objetivam a adoção de medidas cautelares patrimoniais, o Estado requerente deve demonstrar a correspondência da tutela cautelar decretada ou solicitada com a possível condenação por fato típico segundo o ordenamento do Estado requerente ou também do Estado requerido (a depender da exigência ou não de dupla incriminação). Deve demonstrar, ainda, a proporcionalidade da medida ao possível provimento final a ser decretado no processo estrangeiro em caso de condenação $^{486}$.

Tormentoso se torna responder se a ausência de um desses critérios poderia ser motivo para a denegação do pedido pelo Estado requerido.

Como diferenças entre os sistemas processuais penais sempre existirão, é difícil estabelecer um limite tolerável a partir do qual estaria configurada eventual violação à ordem pública. Evidentemente, vários fatores são levados em consideração pelo Estado requerido, como, por exemplo, o grau de cognição do instrumento de cooperação e o ordenamento interno do Estado requerido, de maneira que cada caso tende a tomar seu próprio desfecho.

\footnotetext{
${ }^{486}$ No Brasil, o trâmite dos pedidos de cooperação ativa tem um regramento sucinto. O Código de Processo Civil, nos artigos 201 e seguintes, regula o procedimento das cartas rogatórias ativas. O artigo 202 traz o requisitos essenciais: a indicação dos juízes de origem e de cumprimento do ato; o inteiro teor da petição, do despacho judicial e do instrumento de mandato conferido ao advogado; a menção ao ato processual, que lhe constitui o objeto; o encerramento com a assinatura do juiz. Deve o juiz mandar trasladar quaisquer outras peças, ou instruí-las com mapa, desenho ou gráfico, sempre que esses documentos forem examinados na diligência pelas partes, peritos ou testemunhas. Ademais, os tratados costumam dispor a respeito dos documentos que devem instruir os pedidos de assistência jurídica ativa.
} 
Dentre os princípios da cooperação jurídica internacional discorridos por RAÚL CERVINI $^{487}$, destaca-se o chamado princípio da proteção dos direitos patrimoniais frente a medidas suscetíveis de causar gravame irreparável, inferido do Protocolo de Assistência Jurídica Mútua em Assuntos Penais - Mercosul (Decreto n. 3.468, de 17 de maio de 2000).

Nos termos do Protocolo de Assistência Jurídica Mútua em Assuntos Penais Mercosul, medidas patrimoniais de natureza coercitiva regem-se pela lei processual e substantiva do Estado requerido (artigo 22) e só podem ser cumpridas pela autoridade deste "se contiver informações suficientes que justifiquem a procedência da medida" (artigo 22.1), assegurando-se, ainda, os interesses "de terceiros sobre objetos que se pretendam alcançar" (artigo 22.2).

Trata-se de importante postulado em matéria de recuperação de ativos, na medida em que contribui no balanceamento entre a eficiência na cooperação jurídica internacional e os direitos patrimoniais da pessoa atingida. E a despeito de estar imbuído nas normas do Protocolo do Mercosul, poderia - e deveria - ser observado para todos os pedidos de cooperação, ainda que fundamentados em outros tratados internacionais ou mesmo com mero compromisso de reciprocidade.

\subsubsection{Referibilidade das medidas cautelares patrimoniais em cooperação jurídica internacional e o princípio da dupla incriminação}

Tratamos nos capítulos anteriores sobre importante critério da tutela cautelar penal relativo à referibilidade. A medida cautelar penal deve se referir a eventual punição por fato que diga respeito a crime específico, a fim de assegurar a utilidade e eficácia do provimento final condenatório que tenha por objeto tal delito ${ }^{488}$.

A questão que se faz presente é se a medida cautelar patrimonial solicitada em auxílio internacional deve se referir a um fato que seja típico segundo a legislação do Estado requerente, segundo a legislação do Estado requerido ou a de ambos.

Se tanto na cooperação ativa quanto na passiva, o cumprimento da medida visa a satisfazer uma tutela cautelar penal em relação ao processo estrangeiro, então, prima

\footnotetext{
${ }^{487}$ CERVINI, Raul; TAVARES, Juarez. Princípios da cooperação judicial penal internacional no Protocolo do Mercosul, cit.

${ }^{488}$ BADARÓ, Gustavo Henrique Righi Ivahy. Medidas cautelares patrimoniais no processo penal, cit., p. 171.
} 
facie, seria coerente exigir referibilidade da medida cautelar patrimonial tomada no Estado requerido em relação ao crime objeto do processo estrangeiro que lhe deu causa, em trâmite no Estado requerente.

Com efeito, são estreitos os laços que vinculam o processo cooperacional ao processo estrangeiro destinatário da medida solicitada. Considerando a instrumentalidade das medidas cautelares patrimoniais, pode-se afirmar que a medida deve se referir à punição por crime apurado no processo estrangeiro destinatário da medida, o processo principal. Assim, o bloqueio de bens solicitado por cooperação internacional não prescinde de se referir aos fatos objeto do processo estrangeiro, que, por sua vez, devem ser típicos à luz do ordenamento do Estado requerente.

Contudo, dilema maior surge quando se indaga se deveria haver referibilidade da medida em relação a fatos que também se mostrem típicos à luz do Estado requerido.

Responder a essa questão sobre a cooperação ativa é tarefa das mais tormentosas. Como a medida é tomada em conformidade com as normas do Estado requerido, há de se considerar vários fatores, como a relação entre os Estados requerente e requerido, ou seja, se existe tratado multilateral ou bilateral de assistência mútua entre ambos e os termos específicos desse tratado; o paradigma em que se encontram os Estados - da confiança mútua ou da cooperação interessada, o que influenciará o grau de desconfiança em relação aos atos judiciais estrangeiros; e a legislação do Estado requerido.

Para os países que se encontram sob o paradigma da cooperação interessada, como o Brasil, a referibilidade das medidas cautelares patrimoniais acaba sendo definida a depender do tratado internacional aplicado ao caso e do que nele se tenha estabelecido a título de dupla incriminação ${ }^{489}$.

Tomando como exemplo os tratados Brasil-Peru e Brasil-Ucrânia, o concernido de carta rogatória oriunda do Peru poderá ter seus bens constritos somente se os fatos objeto do processo estrangeiro principal forem típicos segundo as leis do Estado requerido $^{490}$, ao passo que o concernido de uma carta rogatória solicitada pelos Estados

\footnotetext{
${ }^{489}$ Importante lembrar que há tratados (a maioria) que exigem dupla incriminação a todos os atos cumpridos em assistência jurídica; já outros o estabelecem apenas a medidas cautelares patrimoniais, havendo, ainda, aqueles tratados que não exigem dupla incriminação. V. item 3.2.1.2 do Capítulo III, relativo às medidas cautelares patrimoniais no contexto da cooperação jurídica internacional.

490“Para a execução de mandados de busca de pessoas e registros, confiscos, indisponibilidade de bens, de sequestro com fim de prova e interceptação telefônica por ordem judicial devidamente motivada, assim como para a execução de medidas que envolvam algum tipo de coerção, a assistência será prestada somente
} 
Unidos será atingido, independentemente de os fatos se mostrarem típicos ou não no Estado requerido $^{491}$.

Ao se submeter a referibilidade das cautelares patrimoniais em cooperação ao que se convencionou em tratado a respeito da dupla incriminação, permite-se que a tutela dos direitos e garantias fundamentais tenha uma extensão demasiadamente elástica, a depender do processo em que o concernido é investigado, acusado ou condenado (se é nacional ou estrangeiro), além das cláusulas do tratado internacional correspondente.

Cria-se, assim, inadmissível diferença de tratamento do Estado brasileiro em relação a: brasileiros residentes no país e concernidos brasileiros residentes e processados no exterior; brasileiros e concernidos não brasileiros; e entre os concernidos de diferentes nacionalidades.

A contrariedade à ordem pública é ainda mais manifesta no auxílio direto, em que o pedido de medida cautelar é proposto pelo Ministério Público Federal e decidido, inclusive com cognição plena, pela Justiça Federal de primeira instância. A depender das disposições em tratado, o Juiz Federal brasileiro poderá decidir pelo sequestro de bem localizado no Brasil para assegurar processo outro (estrangeiro) cujo objeto não diga respeito a fatos típicos de acordo com as leis penais internas, medida que seria claramente ilegal se não fosse pelo fato de ter sido representada por outro Estado estrangeiro.

Ora, independentemente de ser o concernido nacional ou estrangeiro, não se admite tratamento não igualitário entre nacionais e estrangeiros fora das hipóteses taxativamente impostas na Constituição Federal. É de se questionar a constitucionalidade dos tratados internacionais incorporados ao ordenamento jurídico brasileiro no que diz respeito à não exigência de dupla incriminação a quaisquer medidas.

Ademais, sob o prisma da trilateralidade da cooperação jurídica internacional, o concernido está vinculado, como sujeito de direitos, tanto ao Estado requerente quanto ao Estado requerido, de modo que ambos, Estado requerente e requerido, assumem o dever de dupla observância das garantias fundamentais do concernido, de acordo com seus ordenamentos internos.

quando o fato que lhe der motivo na parte requerente estiver previsto como delito também na legislação da parte requerida, ou quando a pessoa envolvida no pedido de assistência tiver manifestado livremente seu consentimento de forma escrita" (artigo 2, inciso III, do Decreto n. 3.988/2001, Tratado Brasil-Peru).

491 “A assistência será prestada ainda que o fato sujeito a investigação, inquérito ou ação penal não seja punível na legislação de ambas as partes” (artigo $1^{\circ}$, inciso III, do Decreto n. 5.984/2006, Tratado BrasilUcrânia). 
À medida que a cooperação se desenvolve regional e internacionalmente, aumentando a confiança entre os Estados, a permitir, como na União Europeia, a livre circulação de decisões judiciais sem exigência de dupla incriminação, instaura-se cenário de maior - e melhor - harmonização entre os sistemas processuais penais, no qual a discussão a respeito da referibilidade das medidas cautelares patrimoniais cumpridas em auxílio mútuo acaba perdendo o sentido.

$\mathrm{Na}$ União Europeia, a aplicação do princípio do reconhecimento mútuo das decisões judiciais implementa a cooperação jurídica no sentido de fazer circular decisões judiciais entre os Estados, dentro de um espírito de confiança nas decisões proferidas por magistrados de outros Estados. Por isso, uma medida cautelar patrimonial penal pode ser solicitada diretamente pelo magistrado de país integrante da União Europeia a outro e é executada independentemente de qualquer discussão a respeito da referibilidade ${ }^{492}$.

\subsection{Legitimidade}

No que toca ao tema da legitimidade na cooperação jurídica internacional em matéria penal, trataremos da legitimidade ativa, que reúne inúmeras discussões no contexto das medidas cautelares patrimoniais ${ }^{493}$.

Por opção metodológica, será feita a diferenciação entre a legitimidade ativa para solicitar, a outro Estado, assistência internacional penal e a legitimidade ativa para requerer a medida constritiva patrimonial a ser objeto da assistência internacional. A primeira remete à autoridade competente para solicitar, ao juiz estrangeiro, a efetivação, no território nacional deste, da medida de urgência decretada ou representada no exterior ${ }^{494}$; a segunda diz respeito à competência para, no processo judicial estrangeiro, dar o impulso processual necessário à consecução da medida cautelar patrimonial.

\footnotetext{
${ }^{492}$ O Juiz do Estado de execução da medida faz apenas o juízo de legalidade da medida. Contudo, mesmo diante do princípio do reconhecimento mútuo das decisões judiciais, a ausência de harmonização substancial dos sistemas jurídicos ainda é um entrave à eficácia dos mecanismos de cooperação judiciária.

${ }^{493} \mathrm{O}$ tema da legitimidade passiva - com a possibilidade de o concernido influir no pedido de cooperação ou mesmo de participar do processo cooperacional - será englobado no item 4.5 do presente capítulo.

${ }^{494}$ Mediante impulso processual da parte ou de ofício, a autoridade judicial estrangeira pode decretar a medida cautelar patrimonial nos autos do processo estrangeiro e solicitar, à autoridade judicial estrangeira, o cumprimento da medida no território nacional desta - o que se dará por meio de carta rogatória - ou pode simplesmente deixar de decidir e representar à autoridade do Estado requerido para que, de acordo com as regras processuais de seu ordenamento interno, tome as providências necessárias - o que se dará através do auxílio direto.
} 


\subsubsection{Legitimidade ativa para requerer assistência jurídica internacional}

A cooperação jurídica internacional pode ter iniciativa tanto do juiz quanto da parte. É de iniciativa do juiz a cooperação quando, no curso de processo jurisdicional, parte da autoridade judicial a provocação direta dos agentes públicos do Estado requerido, para que cumpram ato de impulso processual. De outra parte, a cooperação jurídica de iniciativa da parte ocorre quando o interessado, ente público ou privado, provoca diretamente os agentes públicos do outro país, no intuito de dar efetividade ao processo estrangeiro ${ }^{495}$.

Na cooperação em matéria penal, considerando as características oficiais de que se reveste o processo criminal, é mais comum o pedido de assistência de iniciativa de autoridade judicial ${ }^{496}$, sobretudo quanto se solicita o cumprimento de medidas cautelares patrimoniais - apesar de países admitirem a decretação de medidas assecuratórias penais pelo próprio órgão persecutório, muitas vezes o mesmo órgão que solicita o cumprimento da medida diretamente da autoridade pública do Estado requerido. Nestes casos, a depender das normas do ordenamento do Estado requerido, a solicitação da assistência jurídica diretamente pelo órgão persecutório pode levantar discussão a respeito de sua legitimidade ativa.

$\mathrm{Na}$ jurisprudência brasileira, em várias ocasiões se afirmou que o devido processo legal brasileiro, por contar com regras específicas de competência na tutela dos direitos fundamentais dos acusados, deveria ser seguido cabalmente nos pedidos de cooperação passiva, sob pena de indeferimento, pouco importando as diferentes opções do ordenamento jurídico do Estado requerente ${ }^{497}$.

Importante salientar, todavia, que o artigo 784 do Código de Processo Penal estabelece que as cartas rogatórias penais passivas emanadas de "autoridades estrangeiras competentes" independem de homologação. O Código de Processo Penal está em perfeita harmonia com a Lei de Introdução às Normas do Direito Brasileiro, cujo artigo 12, parágrafo $2^{\circ}$, também dispondo sobre os pedidos de carta rogatória passiva, prevê que: "A autoridade judiciária brasileira cumprirá, concedido o exequatur e segundo a norma

\footnotetext{
${ }^{495}$ SILVA, Ricardo Perlingeiro Mendes da. Cooperação jurídica internacional e auxílio direto. Revista CEJ, Brasília, n. 32, p. 76, jan./mar. 2006. No mesmo sentido, VERGUEIRO, Luiz Fabricio Thaumaturgo. Apontamentos gerais sobre a cooperação jurídica internacional e suas modalidades, cit., p. 381.

${ }^{496}$ VERGUEIRO, Luiz Fabricio Thaumaturgo. Apontamentos gerais sobre a cooperação jurídica internacional e suas modalidades, cit., p. 381.

${ }^{497}$ Supremo Tribunal Federal, HC n. 91.002/RJ, Rel. Min. Marco Aurélio, j. 26.02.2008, DJE de 11.04.2008.
} 
estabelecida pela lei brasileira, as diligências deprecadas por autoridade estrangeira competente, observando a lei desta, quanto ao objeto das diligências".

Ora, partindo da premissa de que não há palavras inúteis na lei, a expressão "autoridades estrangeiras competentes" claramente se impõe como barreira à pretensão de transpor nosso modelo de autoridade competente aos demais países. A legitimidade ativa para requerer a assistência jurídica passiva recai sobre a autoridade estrangeira competente segundo o ordenamento do Estado requerente.

Nem haveria de ser diferente. Como nenhum país possuirá exatamente o mesmo modelo de processo penal, obviamente exigir que a integralidade do modelo brasileiro seja seguida pelos países com os quais o Brasil coopera inviabilizaria a própria cooperação jurídica internacional em matéria penal, e externaria uma visão míope e xenófoba, na medida em que tenta impor a supremacia da ordem jurídica brasileira em detrimento das demais, porém desconsidera a soberania dos demais Estados para dispor em sentido diverso em seus modelos processuais penais e para, até mesmo, oferecer o mesmo tratamento em relação aos pedidos de auxílio oriundos do Brasil. Consequentemente, pela norma da reciprocidade, os outros países também poderiam impor barreiras semelhantes, deixando de cooperar com o Brasil. Perde o Brasil e perde também toda a comunidade internacional.

De qualquer maneira, são cada vez mais comuns pedidos de cooperação remetidos diretamente por órgãos de persecução penal (judiciais e não judicias), como o Ministério Público, apesar de certa relutância dos Tribunais brasileiros ${ }^{498}$. Esse fenômeno ocorre não somente pela prerrogativa que é dada aos órgãos persecutórios, sobretudo nos países do common law, mas, principalmente, por ser uma tendência a partir dos modernos acordos internacionais celebrados pelo Brasil acerca da assistência jurídica internacional.

\footnotetext{
498، Consoante dispõe o inciso I do artigo 202 do Código de Processo Civil, a carta rogatória é instrumento próprio à cooperação entre Judiciários, devendo o subscritor estar integrado a esse Poder. Não há possibilidade de Procuradoria da República de Estado estrangeiro requerer à autoridade judiciária brasileira o cumprimento de carta rogatória por si expedida" (STF, HC n. 91.002/RJ, Rel. Marco Aurélio, j. 26.02.2008. Neste julgamento, entendeu o Min. Marco Aurélio, relator, que o art. 202 do CPC prevê como requisitos formais indispensáveis à valia do ato em cooperação jurídica internacional passiva a indicação do juízo de origem e do juízo de cumprimento do ato. Assim, concluiu que o Brasil apenas aceitou cumprir Cartas Rogatórias de órgãos judiciais. Entretanto, o artigo de lei referenciado diz respeito aos requisitos formais da cooperação ativa, incidente, por óbvio, às autoridades brasileiras e não às autoridades estrangeiras. Em semelhante sentido, decidiu o Supremo Tribunal Federal no julgamento do HC n. 87.759 (relator Min. Marco Aurélio, j. 26.02.2008, DJE 18.04.2008). Entretanto, da decisão, o Ministério Público opôs embargos de declaração, e o Min. Marco Aurélio reviu seu posicionamento em decisão publicada na data de 17.03.2009, admitindo o cumprimento de carta rogatória passiva solicitada, no caso, pelo Ministério Público italiano, somente porque "na Itália, o Ministério Público integra o sistema judiciário - artigos 107, 108 e 112, todos inseridos no título denominado "A Magistratura" (Parte II, Título IV, da Constituição italiana)". O voto do Min. Marco Aurélio foi acompanhado por unanimidade pelos demais Ministros.
} 
Com efeito, a Convenção das Nações Unidas contra o Crime Organizado Transnacional (Decreto n. 5.015, de 12 de março de 2004), em seu artigo 27, parágrafo $2^{\circ}$, estabelece a possibilidade de os Estados-Partes intensificarem a repressão ao crime organizado através da cooperação direta entre suas autoridades investidas de competência para a investigação criminal ${ }^{499}$.

A Convenção contra o Tráfico Ilícito de Entorpecentes e de Substâncias Psicotrópicas (Decreto n. 154, de 26 de junho de 1991) prevê, no artigo $9^{\circ}$, parágrafo $1^{\circ}$, "a" e "b", que os Estados-partes deverão colaborar estreitamente entre si, visando à supressão da prática dos delitos descritos na convenção, mediante canais de comunicação firmados entre seus órgãos e serviços competentes e, frise-se, pela cooperação mútua na condução de inquéritos policiais ${ }^{500}$.

A Convenção das Nações Unidas contra a Corrupção (Decreto n. 5.687, de 31 de janeiro de 2006) tem por âmbito de aplicação tanto a investigação quanto a instrução judicial da corrupção (artigo $3^{\circ}$, paragrafo $1^{0501}$ ) e estabelece aos Estados-partes a adoção das medidas que sejam necessárias, em conformidade com sua legislação interna, para estabelecer a cooperação entre seus organismos encarregados de investigar e processar judicialmente os delitos (artigo 38, caput $^{502}$ ).

No mesmo sentido - e de maneira bem expressa -, o Protocolo de Assistência Jurídica Mútua em Matéria Penal do Mercosul (Decreto n. 3.468, de 17 de maio de 2000)

\footnotetext{
499، AArt. 27... 2. Para dar aplicação à presente Convenção, os Estados Partes considerarão a possibilidade de celebrar acordos ou protocolos bilaterais ou multilaterais que prevejam uma cooperação direta entre as suas autoridades competentes para a aplicação da lei e, quando tais acordos ou protocolos já existam, considerarão a possibilidade de os alterar. Na ausência de tais acordos entre os Estados Partes envolvidos, estes últimos poderão basear-se na presente Convenção para instituir uma cooperação em matéria de detecção e repressão das infrações previstas na presente Convenção. Sempre que tal se justifique, os Estados Partes utilizarão plenamente os acordos ou protocolos, incluindo as organizações internacionais ou regionais, para intensificar a cooperação entre as suas autoridades competentes para a aplicação da lei”.

500، 1. As partes colaborarão estreitamente entre si, em harmonia com seus respectivos ordenamentos jurídicos e sua administração, com o objetivo de aumentar a eficácia das medidas de detecção e repressão, visando à supressão da prática de delitos estabelecidos no parágrafo 1 do artigo 3. Deverão fazê-lo, em particular, com base nos acordos ou ajustes bilaterais ou multilaterais: a) estabelecer e manter canais de comunicação entre seus órgãos e serviços competentes, a fim de facilitar o intercâmbio rápido e seguro de informação sobre todos os aspectos dos delitos estabelecidos de acordo com o parágrafo 1 do artigo 3, inclusive, sempre que as partes interessadas estimarem oportuno sobre seus vínculos com outras atividades criminosas; b) cooperar entre si na condução de inquéritos referentes aos delitos estabelecidos de acordo com o parágrafo 1 do artigo 3, que tenham caráter internacional...".

501،1. A presente Convenção se aplicará, de conformidade com suas disposições, à prevenção, à investigação e à instrução judicial da corrupção e do embargo preventivo, da apreensão, do confisco e da restituição do produto de delitos identificados de acordo com a presente Convenção".

502 “Art. 38. Cada Estado-Parte adorará as medidas que sejam necessárias, em conformidade com sua legislação interna, para estabelecer a cooperação entre, de um lado, seus organismos públicos, e, do outro, seus organismos encarregados de investigar e processar judicialmente os delitos...”.
} 
dispõe que "As solicitações transmitidas por uma Autoridade Central com amparo no presente Protocolo se basearão em pedidos de assistência de autoridades judiciais ou do Ministério Público do Estado requerente encarregadas do julgamento ou investigação de delitos" (destacamos).

Também nos acordos bilaterais firmados pelo Brasil em matéria de assistência jurídica em matéria penal, apenas os tratados Brasil-Itália e Brasil-França, por sinal, um dos tratados bilaterais mais antigos, aludem ao pedido de cooperação feito por autoridades judiciárias ${ }^{503}$. Os demais tratados ${ }^{504}$ trabalham, em geral, com a legitimidade ativa de "autoridades competentes" para a condução da investigação, ação penal ou de procedimentos relacionados à solicitação, sem distinção entre órgãos judiciais e persecutórios ${ }^{505}$.

Nos últimos anos, tem ganhado força na jurisprudência brasileira o chamado princípio da equivalência, que parte do pressuposto de que os sistemas processuais penais dos países envolvidos na cooperação não são exatamente os mesmos, portanto é preciso reconhecer "a equivalência das medidas previstas em ambos os países" 506 . Trata-se, aliás, de princípio consagrado na Convenção Interamericana sobre Assistência Mútua em Matéria Penal ${ }^{507}$.

\footnotetext{
${ }^{503}$ Tratado Brasil-Itália (Decreto n. 862, de 9 de julho de 1993), artigo $1^{\text {o }}$, parágrafo $1^{\circ}$ : “ 1 . Cada uma das partes, a pedido, prestará à outra parte, na forma prevista no presente Tratado, ampla cooperação em favor dos procedimentos penais conduzidos pelas autoridades judiciárias da parte requerente" (destacamos); Tratado Brasil-França (Decreto n. 3.324, de 30 de dezembro de 1999), artigo 3o parágrafo 1": "1. O Estado requerido fará executar, nas formas previstas por sua legislação, os pedidos de cooperação relativos a um caso penal que lhe forem dirigidos pelas autoridades judiciárias do Estado requerente, e que tiverem por finalidade cumprir atos de investigação ou instrução, ou apresentar elementos de prova, autos ou documentos" (destacamos). É importante salientar, contudo, que, no sistema italiano, o Ministério Público é composto por Magistrados e integra o Poder Judiciário (BUONO, Carlos Eduardo de Athayde; BENTIVOGLIO, Antônio Tomás. A reforma processual penal italiana - reflexos no Brasil: novos institutos processuais: procedimentos e ritos abreviados: a influência anglo-saxônica. São Paulo: Ed. Revista dos Tribunais, 1991. p. 46).

${ }^{504}$ Os demais tratados bilaterais firmados pelo Brasil em matéria de assistência jurídica em matéria penal são: Brasil-Cuba, Brasil-China, Brasil-EUA, Brasil-Colômbia, Brasil-Peru, Brasil-Portugal, Brasil-Coréia do Sul, Brasil-Ucrânia, Brasil-Suriname, Brasil-Suíça, Brasil-Espanha e Brasil-Canadá.

${ }^{505}$ No mesmo sentido, v. WEBER, Patrícia Nuñez. A cooperação jurídica internacional em medidas processuais penais, cit., p. 112-113; ARAÚJO, Nádia de (Coord.). Cooperação jurídica internacional no Superior Tribunal de Justiça: comentários à Resolução nº 9/2005, cit., p. 93-94.

${ }^{506}$ Embora no contexto da extradição, ponderou o então Ministro do Supremo Tribunal Federal Djaci Falcão: “(...) é de se atentar para que o sistema processual na Suíça, como na França, não é idêntico ao brasileiro. Adota-se naqueles países uma instrução preparatória e obrigatória em matéria de crime, confiada ao juiz de instrução, sob o controle do tribunal de acusação. (...) não podemos ditar regras ao direito alienígena, como se estivéssemos tratando exatamente da nossa prisão preventiva. Basta-nos a equivalência das medidas previstas em ambos os países" (Extradição n. 336, Requerente: Governo da Suíça, Extraditando: Raphael Fratola, j. 18.05.1977, p. DJE 09.08.1977). O princípio da equivalência foi posteriormente empregado em julgados do Supremo Tribunal Federal, por exemplo: Extradição n. 504, j. 19.02.1990 e HC n. 90.485, j. 08.06.2007.

507 “Art. $4^{\circ}$. A assistência a que se refere a presente Convenção, levando em conta a diversidade dos sistemas jurídicos dos Estados partes, basear-se-á em pedidos de cooperação das autoridades encarregadas da investigação ou do julgamento de delitos no Estado requerente".
} 
O controle que poderia ser feito pelo Estado requerido nos pedidos de cooperação passiva não seria analisar se a autoridade solicitante da medida cautelar insere-se no rol de autoridades competentes segundo o ordenamento jurídico do Estado requerido, mas, sim, se por detrás do específico pedido não repousaria eventual violação de direitos e garantias fundamentais internacionalmente reconhecidos por tratados de caráter humanitário.

Assim, por exemplo, entendemos ser mais relevante verificar os critérios pelos quais se chegou à designação daquela autoridade estrangeira solicitante da medida - tendo em vista a vedação aos juízos de exceção em tratados internacionais incorporados ao ordenamento brasileiro - do que verificar se a autoridade solicitante da medida, em si, seria ou não competente para solicitá-la no Brasil.

Neste caso, mesmo o Estado requerente e o Estado requerido optando de maneira diversa em relação à legitimidade ativa para requerer determinada medida, a cooperação jurídica internacional penal seria pautada e viabilizada (ou não) a partir do compromisso comum de ambos os países de garantir um juízo imparcial aos seus cidadãos, e não pelas diferentes opções processuais.

Por fim, se são cada vez mais admitidos no cenário internacional pedidos de assistência jurídica diretamente por órgãos de persecução penal, por outro, a situação jurídica dos particulares na cooperação em matéria penal ainda encontra entraves. Mesmo que se considere parte na ação penal, o Ministério Público vale-se de sua prerrogativa como órgão estatal para estar no rol de entes públicos legitimados ativos para solicitar assistência jurídica internacional. Mas, semelhante raciocínio não se pode dizer em relação ao particular que também figure como parte na ação penal.

Exemplos extraídos da doutrina de cooperação de iniciativa do particular são escassos e dizem mais respeito à esfera civil que penal ${ }^{508}$. Importante mencionar a previsão, em convenções internacionais que tratam da assistência jurídica em matéria civil,

\footnotetext{
${ }^{508}$ RiCARDo PERlingeiro MENDES DA Silva cita como exemplo de cooperação jurídica de iniciativa do particular: "a execução de sentença, a qual deve ser ordinariamente proposta perante o juiz do Estado que proferiu a sentença de conhecimento, salvo se, $a b$ initio, a execução não estiver ao alcance do juiz estrangeiro, hipótese em que o devedor por exemplo, não mais residir no território. Nesse caso deverá haver aforamento da execução noutro Estado. A decisão judicial sobre coisa julgada estrangeira ou litispendência internacional, nos sistemas em que for admitida, ao depender de manifestação prévia do juiz do Estado requerido quanto à compatibilidade da coisa julgada ou do processo pendente no exterior com os princípios fundamentais daquele Estado, configura mais um exemplo de cooperação jurisdicional de iniciativa da parte" (Cooperação jurídica internacional e auxílio direto, cit., p. 77).
} 
da possibilidade de a parte solicitar, diretamente da autoridade judicial do Estado requerido, o cumprimento de certas medidas cautelares ${ }^{509}$. Porém, mesmo nestes casos, a possibilidade de o particular tomar a iniciativa do pedido de cooperação jurídica é medida que se mostra excepcional.

Nos demais casos de assistência jurídica internacional e para atos de natureza penal, sobretudo nas medidas cautelares patrimoniais, observa SolAngE MENDES DE SouZA que aos particulares e, em especial, ao acusado não é conferida legitimidade ativa nos tratados em geral, de modo que eles não podem solicitar diretamente a assistência jurídica internacional no interesse de sua defesa da ação penal. Permite-se-lhes eventual oposição perante o Estado requerido, geralmente por intermédio de embargos ${ }^{510}$, como ocorre no Brasil em relação aos pedidos de carta rogatória passiva e da homologação de sentença estrangeira ${ }^{511}$.

Portanto, a iniciativa do particular na cooperação judicial sucede em caráter subsidiário à cooperação de iniciativa do juiz ${ }^{512}$, a fim de assegurar a garantia do juiz natural $^{513}$. Não significa dizer que a parte, sobretudo o acusado, estaria impedida de tomar iniciativa no sentido de obter algum ato jurisdicional no território de outro país no interesse

\footnotetext{
${ }^{509}$ A título de exemplo, artigo 15 da Convenção Interamericana sobre Obrigação Alimentar (Decreto n. 2.428, de 17 de dezembro de 1997): “As autoridades jurisdicionais dos Estados Partes nesta Convenção ordenarão e executarão, mediante pedido fundamentado de uma das partes ou através do agente diplomático ou consular correspondente, as medidas cautelares ou de urgência que tenham caráter territorial e cuja finalidade seja assegurar o resultado de uma reclamação de alimentos pendente ou por ser instaurada"; artigo $6^{\circ}$, parágrafo $1^{\circ}$, da Convenção Interamericana sobre Restituição Internacional de Menores (Decreto n. 1.212, de 3 de agosto de 1994): "Têm competência para conhecer da solicitação de restituição de menor a que se refere esta Convenção, as autoridades judiciárias ou administrativas do Estado Parte onde o menor tiver sua residência habitual imediatamente antes de seu transporte ou retenção. A critério do autor e por motivo de urgência, a solicitação de restituição poderá ser apresentada às autoridades do Estado Parte em cujo território se encontrar, ou se suponha encontrar-se o menor que tiver sido ilegalmente transportado ou ilegalmente retido, no momento de efetuar-se essa solicitação. Poderá também ser apresentada às autoridades do Estado Parte onde houver ocorrido o fato ilícito que deu motivo à reclamação".

${ }^{510}$ SOUZA, Solange Mendes de. Cooperação jurídica penal no Mercosul: novas possibilidades, cit., p. 200.

${ }^{511}$ A resolução 09 do Superior Tribunal de Justiça estabelece que as cartas rogatórias passivas podem ser impugnadas pela "parte interessada" (artigo $8^{\circ}$ ) ou pelo Ministério Público (artigo 10). Uma vez concedido o exequatur, durante o cumprimento da carta rogatória pelo Juiz Federal competente, podem ser opostos embargos pela parte interessada ou pelo Ministério Público contra quaisquer atos do Juiz, os quais serão julgados pelo Presidente do Superior Tribunal de Justiça (art. 13, parágrafo $1^{\circ}$ ). A respeito dos recursos cabíveis nos pedidos de assistência jurídica, v. item 4.5.4 do presente capítulo.

${ }^{512}$ A submissão do pedido ao exequatur pelo STJ é exigência de natureza constitucional (art. 105, I, “i”), nos casos em que seja preciso o juízo de delibação, pouco importa a iniciativa de quem o provoque. Por isso, entendemos que a subsidiariedade da cooperação de iniciativa da parte decorra, na cooperação passiva, da existência de decisão estrangeira de se submeter ao juízo de delibação e, na cooperação ativa, da obrigatoriedade de os pedidos de cooperação partirem de autoridade judiciária.

513، A propósito da cooperação jurisdicional de iniciativa da parte, registro o seu descabimento sempre que possibilitar a parte processual o direito de reclamar, perante juízo nacional, providência jurisdicional que estiver ao alcance de juiz estrangeiro, pois isso representaria, indiretamente, ofensa ao princípio do juiz natural. Eis um princípio a ser observado pelo legislador de processo internacional." (SILVA, Ricardo Perlingeiro Mendes da. Cooperação jurídica internacional e auxílio direto, cit., p. 77).
} 
processual que lhe assiste, mas terá, primeiro, que requer tal medida ao juiz do processo, a autoridade a quem incumbirá o juízo prévio quanto a viabilidade, legalidade e pertinência do pedido de assistência e que, deferindo-o, deverá encaminhá-lo à autoridade do Estado requerido pelas vias ordinárias cooperacionais.

\subsubsection{Legitimidade ativa para requerer a tutela cautelar patrimonial solicitada em assistência jurídica internacional}

Fundamentalmente, possui legitimidade ativa para requerer a medida cautelar patrimonial em cooperação jurídica de natureza penal o ente - público ou privado interessado em dar o impulso processual necessário no sentido de obter, no exterior, a medida solicitada, assegurando a eficácia e utilidade do processo principal.

Nem sempre coincidirão o legitimado ativo para requerer a medida cautelar patrimonial, o ente que poderá decretar a medida no âmbito jurídico interno e o ente que encaminhará o pedido de assistência jurídica para cumprimento no exterior. A depender do modelo processual do país, a autoridade que solicita a assistência jurídica pode ou não coincidir com a parte interessada na medida e/ou com o ente que, eventualmente, tenha decretado a medida antes do encaminhamento do pedido de assistência.

Nos modelos em que a decretação de medidas cautelares patrimoniais não prescindem de prévia análise e decisão judicial, que é o caso do Brasil, a medida pode ser requerida pelas partes (fase processual), pelo Ministério Público e o acusado, ou pela autoridade persecutória (fase pré-processual), cabendo decidir a autoridade judicial de quem o feito estiver sob a responsabilidade, e esta mesma autoridade é quem encaminhará o pedido de assistência jurídica. Nesse caso, o Estado requerido receberá o pedido de assistência oriundo de autoridade judicial do Estado requerente, para tomada de medida cautelar patrimonial solicitada por outro ente ou no interesse deste.

A medida cautelar patrimonial ainda pode ser decretada de ofício pelo juiz, quando, então, a autoridade judicial que tiver decretado a medida também enviará, independente do requerimento das partes, a solicitação de assistência jurídica ao país onde estiverem localizados os bens objeto de constrição. 
Contudo, seja qual for o caso, neste modelo processual também adotado pelo Brasil, o pedido de cooperação ativa em matéria penal para adoção de medidas cautelares patrimoniais sempre partirá de autoridade judicial.

Entretanto, há sistemas processuais cujo órgão persecutório (pertencente ou não ao poder judiciário) pode decretar, por si, medidas cautelares patrimoniais, em grande parte sendo ele próprio a autoridade que encaminhará o pedido de assistência jurídica ao outro país. Nestes países, o ente estrangeiro que solicita a cooperação jurídica até pode ser o mesmo ente interessado na medida, mas não será necessariamente uma autoridade judicial.

Verifica-se, portanto, cenário de diferentes modelos processuais no que tange à legitimidade ativa para requerer medida cautelar e à legitimidade ativa para solicitar a assistência jurídica, o que pode gerar conflito entre os Estados cooperantes.

Grande parte dos tratados internacionais versam sobre medidas cautelares patrimoniais, mais no intento de assegurar futuro perdimento final de bens (confisco) do que de garantir o ressarcimento do dano causado à vítima.

De qualquer forma, no direito brasileiro, bens de origem lícita podem ser arrestados ou submetidos ao registro da hipoteca legal, para assegurar futura e eventual indenização pelos danos causados com a prática delituosa, medidas estas que devem ser propostas pela vítima. Assim, imagine-se um pedido de cooperação passiva para a adoção de medidas cautelares patrimoniais com vistas, apenas, à garantia do ressarcimento do dano, pretendendo recair sobre os bens lícitos do concernido.

$\mathrm{Na}$ carta rogatória passiva, ainda que o pedido de assistência jurídica advenha de autoridade judicial, se não houver representação por parte da suposta vítima, é de se questionar se deve o Brasil recusar-se ao cumprimento da medida, por violação à ordem pública interna.

Entendemos não haver motivo para recusar o pedido de assistência, pois não podemos impor nosso modelo processual a todos os países com os quais cooperamos. E, ademais, fugiria da cognição restrita do exequatur adentrar na análise do mérito da decisão estrangeira, não se admitindo transformar o juízo de delibação do Superior Tribunal de Justiça em instância recursal do juízo estrangeiro. Portanto, a análise deve ser feita de acordo com o ordenamento do Estado requerente. 
Diferente situação ocorrerá se o pedido for recebido pelo Estado requerido como auxílio direto. Isto porque, em referida modalidade de cooperação, cumprirá ao Ministério Público propor a medida perante a Justiça Federal de primeira instância, em representação processual do Estado requerente. Logo, terá o juiz nacional cognição plena sobre o pedido, inclusive para julgar a legitimidade ativa do Parquet para requerer o arresto ou o registro da hipoteca legal.

De acordo com o critério da referibilidade, a medida solicitada pela via da assistência jurídica dirá sempre respeito à ocorrência de um crime específico que, por sua vez, terá causado um dano a alguém. Caso a medida cautelar patrimonial solicitada se refira a delito cujo lesado seja o próprio Estado requerente, seus órgãos ou patrimônio, entendemos que o Ministério Público, como representante do país solicitante, terá legitimidade ativa para propor a medida perante a Justiça Federal de primeira instância. Porém, havendo uma vítima específica e privada, esta é que deverá representar pela medida solicitada, ainda que por intermédio da autoridade pública remetente do pedido de assistência, sob pena de indeferimento da medida.

Já nos pedidos de cooperação ativa encaminhados pelo Brasil, entendemos que o procedimento deve ser exatamente o previsto na lei processual penal brasileira, qual seja: a vítima representa a autoridade judicial competente para a decretação do arresto ou registro da hipoteca legal dos bens do acusado; o juiz pode deferir a medida nos autos principais, encaminhando pedido de carta rogatória ao Estado onde se encontram os bens do acusado, a fim de que seja executada a decisão, ou, por auxílio direto, pode encaminhar a representação da vítima juntamente com o respectivo despacho - não decisório - em que dá o devido impulso processual, para que a autoridade competente do outro país tome as medidas que forem cabíveis à luz de seu ordenamento interno.

Não há razões plausíveis, a nosso ver, de não se atender na cooperação ativa os procedimentos e requisitos legais da medida cautelar patrimonial antes de ser remetido o pedido de assistência jurídica, independentemente do que dispõem as normas de direito processual penal do Estado requerido.

Outro aspecto diz respeito à obrigatoriedade, segundo a legislação brasileira, da reserva de jurisdição para a decretação de medidas cautelares patrimoniais, motivo usado para a denegação, pelo Brasil, de vários pedidos de cooperação passiva. Ou seja, por 
diversas vezes o Brasil negou o cumprimento de pedidos de medidas cautelares pelo fato de o pedido de assistência jurídica não partir de autoridade judicial.

Para a consecução da ordem pública brasileira, bastaria a existência de ordem judicial para o cumprimento de medidas cautelares patrimoniais, o que pode ser obtido, no plano nacional, mediante a provocação da autoridade persecutória estrangeira, com base nos compromissos assumidos internacionalmente pelo Estado brasileiro.

Neste sentido, se houver tratado internacional bilateral ou multilateral com o Estado requerente, a fim de não inviabilizar a cooperação, entendemos ser pertinente o encaminhamento do pedido de assistência passiva ao Ministério da Justiça, com o fim de providenciar as diligências necessárias ao cumprimento da medida rogada pelo auxílio direto, obviamente, se estiverem presentes os pressupostos necessários. Ou seja, ausência de decisão judicial estrangeira para a medida solicitada pode ser sanada, no Brasil, pela obtenção de decisão por juiz brasileiro ${ }^{514}$.

Assim, é possível fazer o juízo de admissibilidade interno em relação à media cautelar solicitada, viabilizando o atendimento do pedido de assistência jurídica sem que seja preciso exigir, ao Estado requerente, modelo processual perfeitamente idêntico ao modelo brasileiro.

Trata-se, aliás, de medida, no nosso ver, mais favorável ao concernido. No auxílio direto, por ser um processo inteiramente nacionalizado, a pessoa atingida tem a seu dispor todas as defesas e recursos disponíveis em nosso sistema processual penal, podendo, inclusive, exercer sua defesa e o contraditório em suas formas com a devida plenitude, na medida em que se permite cognição absoluta pelo juiz nacional. $\mathrm{O}$ mesmo não aconteceria na carta rogatória, cujo processamento é estreito e de cognição limitada. Por permitir cognição plena, há, ainda, maior controle do Estado brasileiro sobre o mérito da medida

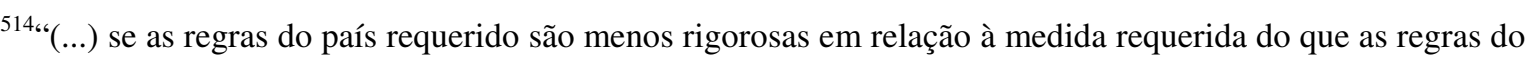
país requerente, o próprio encaminhamento da solicitação da medida ficaria sujeito ao atendimento prévio do país requerente das exigências decorrentes de suas próprias regras" (MORO, Sérgio Fernando. Cooperação jurídica internacional em casos criminais: considerações gerais, cit., p. 31). Tratando sobre o sigilo bancário, cita RAÚL CERVINI et al: "todo caso deverá se fazer primar o princípio do respeito à lei interna processual e substancial do Estado requerido. Isso significa que não poderão ser relegados os requisitos de forma e de fundo que a Lei interna exige para o levantamento judicial do segredo bancário sob simples expediente da cooperação judicial penal internacional. O desconhecimento do princípio do devido respeito à lei interna do Estado requerido transformaria automaticamente a entre-ajuda judicial penal em mera cortesia internacional isenta de garantias jurídicas" (Princípios da cooperação judicial penal internacional no Protocolo do Mercosul, cit., p. 123-124).
} 
solicitada em cooperação, que se sujeitará ao controle pelo Superior Tribunal de Justiça, mesmo que pela via difusa ${ }^{515}$.

Ainda no que se refere à legitimidade ativa, de acordo com o Código de Processo Penal, em seu artigo 222-A, as cartas rogatórias ativas penais serão expedidas pelo Brasil se demonstrada a imprescindibilidade do ato a ser rogado, devendo a parte requerente arcar com os custos do envio. Na visão de DENISE ABADE, isto ocorre porque as cartas rogatórias ativas - o que se estende às demais medidas de cooperação ativa - são disciplinadas sob o manto do temor às manobras protelatórias, ou seja, "o legislador parte, ao que tudo indica, do pressuposto que o requerimento de expedição de Carta Rogatória Ativa é, ab initio, uma possível manobra de defesa visando o retardo do processo" ${ }^{\text {516. }}$.

Esse excessivo combate às manobras protelatórias esconde uma diferença de tratamento entre acusação e defesa, sobretudo em relação aos atos judicias no exterior requeridos pelo Ministério Público, cujas custas são absorvidas pelo Estado, ao contrário dos atos requeridos pela defesa, cujas custas são arcadas pelo acusado (salvo nos casos em que o acusado seja beneficiário da justiça gratuita). Instaura-se a dúvida, pois, se um tratamento processual descompassado como tal não ofenderia a garantia de paridade de armas no processo, corolário do direito constitucional à igualdade no devido processo legal (artigo $5^{\circ}$, I e LIV, da Constituição Federal) ${ }^{517} 518$.

\footnotetext{
${ }^{515}$ Neste caso, deve o Juiz estar atento aos fundamentos do pedido e dos elementos que comprovem a necessidade da medida solicitada. Quando o pedido é originalmente recebido como carta rogatória, é bem possível que o Estado requerente não o tenha instruído com elementos necessários à cognição plena pelo Juiz Federal brasileiro quando depois é recebido em auxílio direto. Havendo a necessidade de complementação do pedido, deve o juiz federal representar ao DCI para que solicite o que for necessário ao Estado requerente, sob pena de indeferimento da medida solicitada. O que não se pode admitir é que o Juiz Federal brasileiro decrete a constrição patrimonial do concernido de forma automática, inaudita altera pars e com base unicamente nas declarações apostas no pedido de auxílio mútuo ou na representação do Ministério Público Federal.

${ }^{516}$ ABADE, Denise Neves. Direitos fundamentais na cooperação jurídica internacional: extradição, assistência jurídica, execução de sentença estrangeira e transferência de presos, cit., p. 329.

${ }^{517}$ Neste sentido: "No trâmite regular e interno de um processo penal no Brasil, o réu, mesmo que com posses, não é obrigado a antecipar o custeio das oitivas e perícias, mesmo em outro Estado da Federação brasileira. Só não poderá requerer prova impertinente ou desnecessária, o que é óbvio, devendo ser evitado o 'requerimento protelatório'. Mas, se for considerada a oitiva ou ainda a perícia imprescindível, não há antecipação do custeio para a Defesa. Tal não ocorre no que tange às Cartas rogatórias Ativas. Ora, se o Poder Judiciário entende que o requerimento de expedição de Carta Rogatória Ativa é manobra protelatória (como é praxe ocorrer no Brasil, em especial nos crimes de colarinho branco) deve indeferilas. Porém, soa contraditório e ofensivo ao princípio da igualdade de armas e ao devido processo legal exigir que a Defesa custeie antecipadamente a produção probatória imprescindível ao justo procedimento da lide penal" (ABADE, Denise Neves. Direitos fundamentais na cooperação jurídica internacional: extradição, assistência jurídica, execução de sentença estrangeira e transferência de presos, cit., p. 329).

${ }^{518}$ Na Ação Penal Originária n. 470/2007 (“Caso Mensalão”), o Supremo Tribunal Federal reafirmou o entendimento no sentido de que os custos do envio de cartas rogatórias solicitadas devem ser arcados pela defesa, se esta for a parte que as requereu. Segundo o Relator, Ministro Joaquim Barbosa, "é importante
} 


\subsection{Participação do concernido}

No processo cooperacional, como visto sobretudo em relação às medidas cautelares patrimoniais cabíveis de causar sério gravame aos bens do investigado, acusado ou condenado, o concernido pode - e deve - participar dos atos objeto do pedido de assistência internacional, vinculando-se de maneira trilateral com o Estado requerente e Estado requerido.

Parcela da doutrina defende que essa legitimação do concernido vai além do direito a peticionar no processo cooperacional e expande-se para "a garantia de utilização de todos os meios licitamente admitidos para o exercício pleno de sua defesa" ${ }^{\circledR 519}$.

A despeito de existir a possibilidade - teórica - de o concernido participar do processo cooperacional, utilizando-se dos meios licitamente admitidos para o exercício de sua defesa, ganham coro as críticas da doutrina à dificuldade do concernido de exercer efetiva e ativamente - direito que lhe assiste no processo cooperacional ${ }^{520}$.

Ademais, determinados diplomas internacionais firmados pelo Brasil vedam o cumprimento de quaisquer solicitações de assistência jurídica internacional feitas pela

esclarecer que, nos termos da lei recém-promulgada, os custos do envio de cada carta rogatória (no caso, seria necessário expedir quatro cartas) deverão ser arcados pelas respectivas defesas, que deverão adiantar os valores de modo a viabilizar a realização da diligência" (Despacho de 6 de fevereiro de 2009, HAIDAR, Rodrigo. Réus do mensalão insistem em oitivas no exterior. Conjur, São Paulo, 16 fev. 2009. Disponível em: <http://www.conjur.com.br/2009-fev-16/reus-mensalao-insistem-oitivastestemunhas-exterior>. Acesso em: 27 dez. 2013).

${ }^{519}$ CERVINI, Raul; TAVARES, Juarez. Princípios da cooperação judicial penal internacional no Protocolo do Mercosul, cit., p. 74.

${ }^{520}$ Da praxe dos tribunais, "O tema [cooperação jurídica internacional em matéria penal] se considera como mera questão entre Estados, vendo-se como algo desprezível os direitos do (sic) sujeitos concernidos, que se entendem suficientemente custodiados pelos big brothers da cooperação (os Estados), pelo qual não há razão para outorgar-lhe oportunidade de defesa e amparo. Como consequência dessa prática, as solicitações de cooperação internacional que solicitam medidas de segundo nível, se expedem, tramitam e são devolvidas, sem notícia nem participação do envolvido, que só tomará ciência tardiamente de que determinados direitos que a Constituição e a lei lhe asseguram foram irrevogavelmente violados, porque já não há possibilidade de deixar sem efeito o ato jurisdicional que ordena a medida, acepticamente qualificada como cooperação internacional" (CERVINI, Raul; TAVARES, Juarez. Princípios da cooperação judicial penal internacional no Protocolo do Mercosul, cit., p. 76); "O papel da defesa na cooperação internacional é colocado em segundo plano, ocorrendo dificuldades tanto na cooperação passiva (quando o pedido vem do exterior) como na ativa (quando o pedido é encaminhado ao exterior). A impressão que se tem é que a cooperação tornou-se um fim em si mesma. Explico-me. Tornou-se instrumento que busca a consecução de um fim imediato (uma oitiva de testemunha, por exemplo), desconectada do processo como um todo. Isto ocorre, em parte, em virtude da natureza híbrida do instituto, que não é puramente de direito processual penal nem de direito internacional. Traz consigo características dos dois ramos do direito e deve seguir alguns de seus princípios básicos. No nosso modelo, as características relacionadas ao direito internacional têm prevalecido, o que causa grande dano ao processo" (SOUZA, Carolina Yumi de. A defesa na cooperação jurídica internacional: reflexões preliminares. Boletim IBCCRIM, São Paulo, v. 18, n. 214, p. 14-15, set. 2010). 
defesa ou no interesse desta, ou seja, que não conferem, ao acusado, legitimidade para, querendo, intervir no pedido de assistência ${ }^{521}$.

Dos mais notórios diplomas internacionais celebrados pelo Brasil, cumprem ser citados o Acordo de Assistência Judiciária Mútua em Matéria Penal Brasil-EUA ${ }^{522}$ e o Protocolo de Assistência Mútua em Assuntos Penais - Mercosul ${ }^{523}$, os quais permitem o cumprimento de pedido de assistência jurídica feito pelo órgão persecutório, mas vedam expressamente a iniciativa e até mesmo a participação do particular (acusado). É de se questionar se essa diferença de tratamento entre acusação e defesa não violaria a garantia de paridade de armas no processo penal.

\subsubsection{Garantia ao contraditório}

Com efeito, viu-se que o processo cooperacional não é um fim em si mesmo nem deve ser vislumbrado como uma questão entre Estados. O processo cooperacional assessora o processo estrangeiro principal e a este se vincula, assegurando-lhe eficácia e utilidade. Deve, portanto, o processo cooperacional firmar-se e desenvolver-se de acordo com as diretrizes do devido processo legal, da mesma maneira como se procede em relação aos processos ordinários tramitados nos Estados requerente e requerido.

Nessa linha de pensamento, quer em decorrência dos diplomas internacionais (multi e bilaterais), quer por força de normas constitucionais e infraconstitucionais e, em última análise, até mesmo por característica própria do Estado democrático de direito ${ }^{524}$ de que são exemplos o Estado brasileiro e grande parte dos países com os quais o Brasil coopera -, às pessoas diretamente interessadas nas medidas cumpridas em assistência jurídica, sobretudo ao concernido, que pode ser afetado em diferentes graus, deve ser assegurada a legitimação para comparecer nos processos cooperacionais e defender

\footnotetext{
${ }^{521}$ SOUZA, Solange Mendes de. Cooperação jurídica penal no Mercosul: novas possibilidades, cit., p. 200.

${ }^{522}$ Artigo $1^{\circ}$, parágrafo $5^{\circ}$ : "O presente Acordo destina-se tão somente à assistência judiciaria mútua entre as Partes. Seus dispositivos não darão direito a qualquer indivíduo de obter, suprimir ou excluir qualquer prova ou impedir que uma solicitação seja atendida". A respeito, v. ARAS, Vladmir. O papel da autoridade central nos acordos de cooperação penal internacional, cit. e CRISSIUMA, Marcos Vidigal de Freitas. A inconstitucionalidade e ilegalidade do acordo de cooperação mútua internacional firmado entre o Brasil e os Estados Unidos da América (MLAT), cit.

${ }^{523}$ Artigo $1^{\circ}$, parágrafo $2^{\circ}$ : “As disposições do presente Protocolo não conferem direitos aos particulares para a obtenção, supressão ou exclusão de provas, ou para se oporem ao cumprimento de uma solicitação de assistência".

${ }^{524}$ CERVINI, Raul; TAVARES, Juarez. Princípios da cooperação judicial penal internacional no Protocolo do Mercosul, cit., p. 82.
} 
plenamente seus direitos. Em outros termos, ao concernido e demais interessados deve ser assegurado o exercício pleno e efetivo da ampla defesa e do contraditório ${ }^{525}$, corolários do due process of law $^{526}$.

A necessidade de garantir ao concernido e demais interessados o exercício da ampla defesa e do contraditório no processo cooperacional revela-se mais proeminente em relação às medidas suscetíveis de causar dano irreparável a bens, em especial, nas medidas cautelares patrimoniais, a merecer atenção redobrada das autoridades dos Estados requerente e requerido.

Dispondo neste sentido, RAÚl CERVINI afirma que, nas medidas cautelares patrimoniais cumpridas em assistência jurídica internacional, o concernido acaba por se ver em dupla vulnerabilidade: primeiro, o concernido desconhece, em geral, que seus bens são objeto de uma medida constritiva desta natureza, e este desconhecimento, geralmente prévio $^{527}$, pode se manter mesmo depois do cumprimento da medida; segundo, mesmo o concernido tomando ciência dos atos processuais levados a cabo no processo cooperacional, a visão da cooperação jurídica internacional como relação entre Estados pode levar os tribunais do Estado requerido a negar-lhe acesso, sob o pretexto da ausência de legitimação ativa e passiva ${ }^{528}$.

\footnotetext{
${ }^{525}$ “E, com efeito, diante do afã por uma integração entre as forças repressoras de todo o mundo para combater o bom combate, unindo esforços e trocando informaç̃̃es não só para coibir delitos financeiros como também para estancar o tráfico internacional de drogas, de armas, o terrorismo, não é de se estranhar que a proteção aos direitos individuais da pessoa humana acabe relegada a segundo plano. Todavia, os princípios constitucionais inscritos em nossa Carta da República de 1988, notadamente o direito ao contraditório e à ampla defesa, devem ter plena incidência também na tramitação dos pedidos de assistência internacional. Isto porque, em meio a interesse dos Estados em intercambiar informações, estará sempre o interesse de um ou mais indivíduos, que pode ser afetado em diferentes graus com o resultado da troca de dados entre requerente e requerido" (CORDANI, Dora Cavalcanti. A cooperação jurídica Internacional em matéria penal no Brasil: as cartas rogatórias e o auxílio direto - controle dos atos pela parte atingida, cit., p. 109).

${ }^{5260 "} \mathrm{Em}$ decorrência da natureza jurisdicional da atividade de cooperação entre os Estados, é conferido aos jurisdicionados brasileiros a possibilidade de oferecer resistência à pretensão jurídica de produção de efeitos no território nacional de atos e sentenças proferidos em foros alienígenas, como corolário às garantias constitucionais do devido processo legal, da ampla defesa e do contraditório..." (ARAÚJO, Nádia de (Coord.). Cooperação jurídica internacional no Superior Tribunal de Justiça: comentários à Resolução $n^{\circ}$ 9/2005, cit., p. 106).

${ }^{527} \mathrm{O}$ desconhecimento prévio muitas vezes é legítimo e necessário para não frustrar o sucesso da medida. Esta questão será tratada no próximo item.

${ }^{528}$ CERVINI, Raul; TAVARES, Juarez. Princípios da cooperação judicial penal internacional no Protocolo do Mercosul, cit., p. 76.
} 


\subsubsection{Contraditório prévio e diferido}

A Constituição Federal brasileira de 1988 assegura o contraditório e a ampla defesa em todos os processos judiciais e administrativos tramitados em solo nacional, além de prever o direito ao devido processo legal ${ }^{529}$.

Em aplicação de tais garantias constitucionais ao contexto da cooperação jurídica internacional, através da Resolução n. 9/2005 do Superior Tribunal de Justiça relativa aos procedimentos dos pedidos de carta rogatória e auxílio direto ativos e passivos -, assegurou-se o direito ao concernido (e outros interessados) de participar do processo cooperacional, podendo oferecer resistência à pretensão jurídica de produção de efeitos, no território nacional, de atos e sentenças representados ou proferidos por autoridades competentes de outros países ${ }^{530}$.

De acordo com o artigo $8^{\circ}$ caput da Resolução n. 9/2005 ${ }^{531}$, no procedimento referente ao juízo de delibação das cartas rogatórias passivas o interessado deverá ser citado para defender seus interesses, podendo oferecer impugnação no prazo de quinze dias. O parágrafo único do artigo $8^{\circ}$ traz exceção ao seu caput e possibilita a realização da medida solicitada mesmo sem prévia oitiva da parte interessada, "quando sua intimação prévia puder resultar na ineficácia da Cooperação Internacional”.

A ressalva feita pelo parágrafo único do artigo $8^{\circ}$ da Resolução n. 9/2005 volta-se diretamente aos pedidos de medidas cautelares patrimoniais em assistência jurídica, porque o prévio conhecimento do pedido pelo concernido pode, efetivamente, inviabilizar a eficácia da diligência. De fato, o contraditório pela parte interessada, se não puder ocorrer previamente ao cumprimento da medida cautelar, deve, então, ser exercido $a$ posteriori, o que a doutrina nacional costuma chamar de contraditório diferido ou postergado $^{532}$. Esta, aliás, é a lição de ANTÔNIO SCARANCE FERNANDES:

\footnotetext{
${ }^{529}$ Constituição Federal, artigo $5^{\circ}$, incisos LIV - “ninguém será privado da liberdade ou de seus bens sem o devido processo legal"; e LV - "aos litigantes, em processo judicial ou administrativo, e aos acusados em geral são assegurados o contraditório e ampla defesa, com os meios e recursos a ela inerentes".

${ }^{530}$ ARAÚJO, Nádia de (Coord.). Cooperação jurídica internacional no Superior Tribunal de Justiça: comentários à Resolução no 9/2005, cit., p. 106.

531 “Art. $8^{\circ}$ A parte interessada será citada para, no prazo de 15 (quinze) dias, contestar o pedido de homologação de sentença estrangeira ou intimada para impugnar a carta rogatória.

Parágrafo único. A medida solicitada por carta rogatória poderá ser realizada sem ouvir a parte interessada quando sua intimação prévia puder resultar na ineficácia da cooperação internacional".

${ }^{532}$ Em diversas oportunidades, entendeu o Supremo Tribunal Federal, embora reconhecesse o direito do concernido de exercer a ampla defesa e o contraditório no processo cooperacional, que, tratando-se de medidas cautelares patrimoniais (ou de qualquer outra medida que possa ser igualmente frustrada se o interessado tomar conhecimento prévio), o contraditório é exercido de maneira diferida: "Carta Rogatória.
} 
“(...) as medidas cautelares são, em regra, determinadas sem audiência do titular do direito restringido, de ofício ou em atenção a requerimento do Ministério Público, do ofendido ou representação da autoridade policial. As perícias são realizadas também sem a participação do investigado ou de seu advogado. A observância do contraditório, nesses casos, é feita depois, dando-se oportunidade ao suspeito ou réu de contestar a providência cautelar ou de combater, no processo, a prova pericial realizada no inquérito. Fala-se em contraditório diferido ou postergado" ${ }^{\text {533 }}$.

Embora o parágrafo único do artigo $8^{\circ}$ da Resolução n. 9/2005 diga respeito aos pedidos de carta rogatória passiva, o mesmo entendimento pode ser adotado nos procedimentos relativos a pedidos de medidas cautelares patrimoniais em auxílio direto passivo. O Juiz Federal brasileiro para quem for distribuída a representação do Ministério Público Federal poderá postergar a citação e manifestação do concernido, se verificar que o prévio conhecimento deste poderá colocar em risco a medida cautelar patrimonial solicitada. Uma vez deferida e cumprida a medida, será dada ciência ao concernido e aos demais interessados (além do próprio Ministério Público Federal, eventuais terceiros de boa-fé), para os fins e efeitos previstos na legislação processual penal brasileira.

Em suma, quanto às medidas cautelares patrimoniais penais cumpridas nos pedidos de assistência jurídica passiva, os interessados, sobretudo o concernido, têm o direito de exercer o contraditório, embora seja lícito e razoável que se dê de maneira postergada, ou seja, após o cumprimento da medida solicitada ${ }^{534}$.

Resta saber se o contraditório diferido nos pedidos de assistência para cumprimento de medidas cautelares patrimoniais penais deve ocorrer somente perante a autoridade do Estado requerido e logo após a satisfação do ato rogado, ou se deve ocorrer

\footnotetext{
Exequatur. Medida cautelar penal. Diligências para identificação e apreensão de bens. Proveito de infração penal. Ciência prévia do paciente. Inadmissibilidade. Risco de frustração das diligências. Caso de contraditório diferido, retardado ou postergado, mediante embargos ou agravo. Garantia de exercício pleno do direito de defesa. Ilegalidade inexistente. HC indeferido. Inteligência do art. $5^{\circ}$, LVI da CF e da Resolução no 9/2005, do STJ. É legítima, em carta rogatória, a realização liminar de diligências sem a ciência prévia nem a presença do réu da ação penal, quando estas possam frustrar o resultado daquelas." (STF, HC n. 89.555, Rel. Min. Cezar Peluso, j. 10.04.2007). Neste sentido, v. STF, HC n. 89.649, Rel. Min. Cezar Peluso, j. 10.04.2007; STF, HC n. 89.651, Rel. Min. Cezar Peluso, j. 10.04.2007; STF, HC n. 90.485-8, Rel. Min. Cezar Peluso, j. 10.04.2007.

${ }^{533}$ FERNANDES, Antonio Scarance. Processo penal constitucional, cit., p. 60. Especificamente, no contexto da cooperação jurídica internacional, também defende RAÚL CERVINI que, normalmente, o desconhecimento inicial do concernido "parece legítimo e necessário quando se trata de diligência cujo conhecimento prévio do indivíduo pode frustrar a eficácia da medida" (Princípios da cooperação judicial penal internacional no Protocolo do Mercosul, cit., p. 76).

${ }^{534}$ Há de se ponderar que o exercício desse contraditório no exterior não se formaria com a contraposição dialética entre concernido e seu acusador, ou seja, a mesma parte que figura no polo ativo do processo principal e, sim, com o Ministério Público do Estado requerido - quando atuar no ato. Poucos tratados, aliás, permitem que a autoridade do Estado requerente participe pessoalmente do ato no Estado requerido.
} 
também perante a autoridade do Estado requerente, assim que retorne o pedido cumprido pela autoridade estrangeira.

Pois bem, mantenha-se em mente que os pedidos de cooperação jurídica internacional são cumpridos na forma prevista no ordenamento do Estado requerido regra do locus regit actum. Consequentemente, a maneira como serão cumpridas as medidas cautelares patrimoniais nos pedidos de cooperação jurídica sempre variará de um país a outro. Por isso, o procedimento adotado para a execução dos pedidos de cooperação jurídica torna-se assunto afeto ao direito interno do Estado de execução e, assim, tratado casuisticamente ${ }^{535}$.

Ademais, dois outros aspectos merecem destaque. Primeiro, defendemos que o concernido tem o direito de exercer a ampla defesa e o contraditório no processo cooperacional, no sentido de demonstrar a improcedência da medida, revertendo-a ou modificando-a, ao comprovar, por exemplo, a origem lícita do bem (no caso de sequestro) ou mesmo oferecendo caução (art. 135, $\S 6^{\circ}$, CPP). Segundo, cuida-se de medida cautelar, portanto a medida deve ser reversível - caso contrário, estaria revestida de efetiva antecipação de pena, a violar o princípio constitucional da presunção de inocência (artigo $5^{\circ}$, LVII, CF).

Portanto, dependendo do instrumento de cooperação que é veiculado o pedido (carta rogatória ou auxílio direto), bem como do sistema processual do Estado requerido, se for permitida uma cognição plena sobre o pedido de assistência jurídica, inclusive com a possibilidade de rediscussão do mérito ${ }^{536}$, deve o juiz brasileiro solicitante da medida advertir a autoridade do Estado requerido acerca da importância de citar o concernido para, querendo, manifestar-se sobre o pedido - contando com a possibilidade de a autoridade estrangeira reverter ou alterar a medida solicitada diante dos argumentos expostos pelo concernido.

Por outro lado, permitindo-se somente uma cognição restrita do pedido pela autoridade do Estado requerido ${ }^{537}$, o exercício do contraditório restará, em parte, limitado,

\footnotetext{
${ }^{535}$ Em diversos casos, como adverte CAROLINA YUMI DE SOUZA, ao concernido torna-se impossível exercer sua defesa e contraditório durante a execução do pedido no exterior, "seja em virtude de fatores de tempo, econômicos ou, ainda, de acesso às autoridades judiciárias estrangeiras" (A defesa na cooperação jurídica internacional: reflexões preliminares, cit.).

${ }^{536}$ Por exemplo, se o pedido for recebido no Estado requerido como auxílio direto, que permite plena cognição da matéria pela da autoridade nacional - logicamente, nos países, como o Brasil, que adoram a doutrina do non-inquiry mitigado, relativa ao reconhecimento da incidência dos direitos fundamentais no processo cooperacional, desde de que previstos em tratado internacional ou nas leis internas do Estado (v. item 1.5.3.1., Capítulo I).

${ }^{537} \mathrm{Em}$ geral, o juízo de delibação nos pedidos de carta rogatória passiva não admitem cognição plena quanto
} 
uma vez que o concernido não terá meios de contestar fatos e rediscutir fatos e provas, ou seja, não poderá, por exemplo, demonstrar a licitude dos bens objeto de sequestro, apontar a inexistência dos requisitos necessários à tutela cautelar nem tampouco apontar eventual desproporcionalidade da medida.

Neste caso, entendemos que o juiz, não tendo citado o concernido quando da emissão do pedido de assistência jurídica (para não frustrar a eficácia da medida), deve fazê-lo quando da devolução do pedido pelo Estado requerido. E, para tanto, poderá o concernido se valer de todos os meio e recursos inerentes no ordenamento brasileiro. Se os argumentos e provas apresentados conduzirem à necessária reforma da decisão, a medida deverá ser revertida pela autoridade judicial competente, que também deverá emitir novo pedido de cooperação jurídica à mesma autoridade do Estado requerido, comunicando a revogação da medida com o consequente pedido de liberação dos bens constritos no exterior ${ }^{538}$.

\subsection{2. Âmbito de defesa: limites}

O âmbito de defesa dos pedidos de assistência jurídica para medidas cautelares patrimoniais penais dependerá, principalmente, do instrumento em que o pedido for veiculado no Estado requerido: carta rogatória ou auxílio direto.

No Brasil, as cartas rogatórias passivas, antes de serem cumpridas por juiz brasileiro, submetem-se ao juízo de delibação do Superior Tribunal de Justiça, pelo qual se confere à decisão estrangeira a mesma eficácia da decisão nacional. Ou seja, busca-se

a mérito da decisão estrangeira e, sim, simples análise sobre aspectos meramente formais do pedido. Ademais, há países que partilham a teoria do non-inquiry integral, que limita a análise dos tribunais do Estado requerido sobre matérias referentes à proteção dos direitos fundamentais do concernido, bastando que fossem cumpridas as regras previstas no tratado ou nos termos da promessa de reciprocidade. A esse respeito, v. ABADE, Denise Neves. Direitos fundamentais na cooperação jurídica internacional: extradição, assistência jurídica, execução de sentença estrangeira e transferência de presos, cit., p. 86-98.

${ }^{538}$ A questão sobre a reversibilidade da medida é importante, para que haja efetivo contraditório. Com efeito, muitos pedidos de cooperação são processados sem que a pessoa atingida sequer tome conhecimento. São temerárias medidas nessas circunstâncias, porque, uma vez concretizadas, trazem prejuízos irremediáveis ao concernido. Até por isso, gera-se dúvida se as medidas patrimoniais cumpridas em cooperação teriam mesmo caráter cautelar. $\mathrm{Na}$ hipótese de a medida constritiva ser revogada pelo Juiz do Estado requerente (depois que a medida já tenha sido cumprida no exterior), mesmo que novo pedido de cooperação seja expedido ao Estado onde se encontram os bens constritos, com o propósito de liberar a gravação sobre esses bens, corre-se o risco de o país requerido negá-lo, sob o argumento de violação à sua ordem pública. Argumentar-se-ia, nesse caso, que os bens constritos cautelarmente somente poderiam ser liberados mediante sentença penal absolutória, segundo o ordenamento interno do Estado requerido. Nessa hipótese, o caráter cautelar da medida se esfacelaria. 
conferir ao ato estrangeiro força obrigatória que originalmente não possuía, em razão de ter sido proferido em circunscrição judicial além dos limites territoriais brasileiros ${ }^{539}$.

Embora a Resolução n. 9/2005 preveja o direito do interessado de oferecer impugnação no procedimento de delibação das cartas rogatórias passivas, o âmbito de alegações da defesa fica reduzido à autenticidade dos documentos, à inteligência da decisão e à observância dos requisitos da Resolução (artigo $9^{\circ}{ }^{540}$ ). Pode-se, ainda, suscitar ofensa à soberania nacional, à ordem pública e aos bons costumes. A autoridade brasileira restringirá sua análise tão somente à adequação dessa decisão proferida pelo Estado estrangeiro aos preceitos básicos do ordenamento pátrio ${ }^{541}$.

Vale dizer: o sistema adotado pelo Brasil não admite novo julgamento de mérito, razão pela qual a doutrina costuma falar que o procedimento de delibação é de contenciosidade limitada, dada a restrição nas matérias de defesa ${ }^{542}$.

Desta forma, no restrito âmbito de cognição da matéria, segundo o modelo de delibação adotado pelo Brasil, o Superior Tribunal de Justiça não poderia fazer o controle da medida cautelar patrimonial solicitada quanto à proporcionalidade, referibilidade e outros requisitos imprescindíveis da tutela cautelar penal. A indagação que fica é: se a análise destes requisitos significa permitir que o STJ figure como instância revisora da decisão estrangeira, o que é vedado nos termos da Resolução, ou se esse âmbito de atuação está adstrito ao campo da ordem pública.

Reafirmamos que a defesa da ordem pública e dos bons costumes não pode ser usada como subterfúgio para a imposição do modelo processual penal pátrio a todos os países com os quais o Brasil coopera, pois inviabilizaria a manutenção dos fluxos cooperacionais, quer porque nunca haverá um modelo que se amolde integralmente ao sistema brasileiro, quer porque os demais países poderão impor semelhante restrição ao pedidos do Brasil por mera reciprocidade, deslocando o Estado brasileiro à margem da moderna cooperação jurídica internacional.

\footnotetext{
${ }^{539}$ ARAÚJO, Nádia de (Coord.). Cooperação jurídica internacional no Superior Tribunal de Justiça: comentários à Resolução nº 9/2005, cit., p. 105.

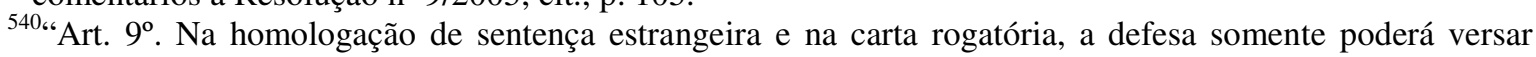
sobre autenticidade dos documentos, inteligência da decisão e observância dos requisitos desta Resolução."

${ }^{541}$ ARAÚJO, Nádia de (Coord.). Cooperação jurídica internacional no Superior Tribunal de Justiça: comentários à Resolução no 9/2005, cit., p. 112-113.

${ }^{542}$ ARAÚJO, Nádia de (Coord.). Cooperação jurídica internacional no Superior Tribunal de Justiça: comentários à Resolução nº 9/2005, cit., p. 112-113.
} 
Sem prejuízo ao quanto afirmamos acima, também defendemos, contudo, que a cláusula da ordem pública ainda é a principal porta de entrada dos direitos fundamentais nos tratados de assistência jurídica internacional em matéria penal celebrados pelo Brasil, sobretudo quando se trata de pedido de carta rogatória passiva ${ }^{543}$.

Por isso, o Superior Tribunal Federal pode - e deve - apreciar matéria relativa à violação de direitos fundamentais do concernido, tal como assegurado nos ordenamentos jurídicos, tanto do Estado requerente quanto do Estado requerido, em defesa não somente de uma ordem pública interna, mas, também, comum, internacional. A solução, a nosso ver, estaria não na diferença entre os sistemas, mas nos pontos de contato em matéria de direitos fundamentais, atendendo-se, assim, ao duplo grau de observância das garantias do concernido em matéria de assistência jurídica, que é decorrente da concepção trilateral da cooperação.

Nesse compasso, o descumprimento da decisão estrangeira sobre requisitos fundamentais da tutela cautelar penal ou de garantias fundamentais do concernido à luz do devido processo legal - assim reconhecidos por ambos os países envolvidos na cooperação, por reflexo de tratados internacionais humanitários - pode ser matéria afeta à defesa nos pedidos de carta rogatória passiva e, assim, sujeita ao juízo de delibação do Superior Tribunal de Justiça, em proteção da ordem pública nacional e internacional.

Por outro lado, sem dúvida, no auxílio direto passivo, tendo o juiz nacional cognição plena sobre o mérito do pedido, adentram no âmbito de arguição de defesa do concernido todas as matérias em direito admitidas, sobretudo ao atendimento dos requisitos à tutela cautelar penal. Isto porque, no auxílio direto, o Estado requerente aceita que o pedido seja submetido originariamente por juiz do Estado requerido, de acordo com seu ordenamento jurídico interno ${ }^{544}$.

\subsubsection{Recursos cabíveis}

Nos pedidos de carta rogatória passiva, as possibilidades de recursos estão previstas no Regimento n. 09/2005. De acordo com o artigo $9^{\circ}$, parágrafo $2^{\circ}$, havendo impugnação pelo concernido, por terceiro ou mesmo pelo Ministério Público Federal às

\footnotetext{
${ }^{543}$ ABADE, Denise Neves. Direitos fundamentais na cooperação jurídica internacional: extradição, assistência jurídica, execução de sentença estrangeira e transferência de presos, cit., p. 327.

${ }^{544}$ Como salienta DIAS TÓFFOLI et al, medidas cautelares patrimoniais, como sequestro de bens ou congelamento de valores bancários também podem ser objeto do auxílio direto. Nesse caso, "o juiz de primeiro grau que recebe o pedido tem cognição plena para apreciá-lo, estabelecendo contraditório para centralizar seu livre convencimento" (TOFFOLI, José Antonio Dias; CESTARI, Virgínia Charpinei Junger. Mecanismos da cooperação jurídica internacional no Brasil, cit., p. 27).
} 
cartas rogatórias de conteúdo decisório ${ }^{545}$, por determinação do Presidente do Superior Tribunal de Justiça os autos poderão ser distribuídos para julgamento pela Corte Especial. Do acórdão da Corte Especial, caberão somente recurso de Embargos de Declaração.

A redação do parágrafo $2^{\circ}$ do artigo $9^{\circ}$ determina que apenas nos casos em que o objeto requerido na carta rogatória seja um ato de cunho decisório, é que serão os autos redistribuídos para julgamento pela Corte Especial ${ }^{546}$, o que acaba acontecendo nos pedidos para execução, no Brasil, de medidas cautelares patrimoniais deferidas por autoridade judicial estrangeira.

Portanto, havendo impugnação, fica claramente limitado o âmbito recursal contra as decisões nas cartas rogatórias passivas quando o objeto for a execução de medidas cautelares patrimoniais, pois, uma vez decididas pela Corte Especial, ao concernido e demais interessados só restará o recurso de Embargos de Declaração. Obviamente, da decisão relativa aos Embargos, ainda poderá ser impetrada, em favor do concernido, Ordem de Habeas Corpus ao Supremo Tribunal Federal (embora não seja propriamente um recurso), com fundamento no artigo 102, inciso I, “i”547, sem prejuízo de eventual Recurso Extraordinário, se estiverem presentes os requisitos necessários (artigo 102, III, da CF).

Uma vez concedido em definitivo o exequatur pelo Superior Tribunal de Justiça, a carta rogatória é remetida para cumprimento pelo Juízo Federal competente. Dispõe o artigo 13, parágrafo $1^{\circ}$, da Resolução n. 9/2005 que, durante o cumprimento da medida, contra quaisquer atos do Juiz, os interessados ou o Ministério Público Federal poderão interpor Embargos no prazo de 10 dias, os quais serão julgados pelo Presidente do Superior Tribunal de Justiça. Da decisão que julgar os Embargos caberá Agravo Regimental (parágrafo $2^{\circ}$ ) e, novamente, eventual Ordem de Habeas Corpus ao Supremo Tribunal Federal.

\footnotetext{
545 “\$ $2^{\circ}$ Havendo impugnação às cartas rogatórias decisórias, o processo poderá, por determinação do Presidente, ser distribuído para julgamento pela Corte Especial".

${ }^{546}$ Consequentemente, o Presidente do Superior Tribunal de Justiça só poderá proferir julgamento monocrático nas cartas rogatórias que requeiram a prática de medidas de mero trâmite (ARAÚJO, Nádia de (Coord.). Cooperação jurídica internacional no Superior Tribunal de Justiça: comentários à Resolução $\mathrm{n}^{\circ}$ 9/2005, cit., p. 121).

${ }^{547}$ A Ordem de Habeas Corpus, por sua maior celeridade, mostra-se mais adequada nos procedimentos de delibação das cartas rogatórias passivas, além de admitir pedido de liminar com o objetivo de suspender a decisão de exequatur até o julgamento definitivo do writ.
} 
Já no auxílio direto passivo, como a representação para a medida cautelar patrimonial é conhecida, processada e executada perante a Justiça Federal de primeira instância, assim como ocorre originariamente em qualquer demanda nacional, compete ao concernido e demais interessados - incluindo o Ministério Público Federal - todos os meios de impugnação e de recurso previstos no ordenamento jurídico nacional às medidas cautelares patrimoniais.

Assim, a decisão que decretar o sequestro de bens poderá ser atacada por meio de Embargos (artigos 129 e 130, I e II, CPP) ${ }^{548}$ opostos perante o Juízo Federal de primeiro grau, em que o concernido poderá se defender, fazendo prova plena da licitude dos bens ou, ainda, demonstrando que a media foi decretada sem que houvesse indícios veementes da proveniência ilícita dos bens. Da decisão que julgar os Embargos, poderá ser interposto Recurso de Apelação, com fundamento no artigo 593, inciso II, CPP.

Entretanto, o julgamento dos Embargos previstos nos incisos I e II do artigo 130, CPP deverá aguardar o trânsito em julgado da sentença da ação penal condenatória, ante o teor do parágrafo único do artigo 130. Assim, instaura-se um impasse no auxílio direto: o pedido de assistência jurídica, uma vez cumprido, não pode ficar sobrestado indefinitivamente no Brasil, aguardando o trânsito em julgado da sentença penal condenatória no exterior ${ }^{549}$.Por outro lado, sendo devolvido o pedido ao Estado requerente, o julgamento dos Embargos resta prejudicado.

Por sua vez, a decisão que decretar o arresto ou registro e especialização da hipoteca legal poderá ser atacada através de Recurso de Apelação (artigo 593, II, CPP). De fato, o auxílio direto permite a contenciosidade plena, permitindo a arguição de quaisquer matérias de mérito em defesa do concernido e a interposição dos recursos cabíveis na legislação pátria. Porém, como o recurso de apelação poderá levar anos até ser julgado e, ainda, sendo cabíveis, em tese, medidas judiciais perante o Superior Tribunal de Justiça e o

\footnotetext{
${ }^{548}$ Parcela da doutrina reconhece três espécies de Embargos: a) Embargos do Terceiro, estranho ao processo (artigo 129); b) Embargos do Acusado (artigo 130, I); c) Embargos do Terceiro de Boa-fé, que adquiriu o bem do acusado (artigo 130, II). V. BADARÓ, Gustavo Henrique Righi Ivahy. Medidas cautelares patrimoniais no processo penal, cit., p. 183. Também é possível encontrar posição na doutrina no sentido de que o sequestro pode ser atacado por meio do Recurso de Apelação (artigo 593, II do CPP) ou mesmo por Mandado de Segurança. No entanto, defendemos o cabimento dos Embargos, como, aliás, está expresso no Código de Processo Penal.

${ }^{549}$ Ainda que se aguarde o trânsito em julgado da sentença condenatória no exterior, esta irradiará seus efeitos, inclusive para os fins de permitir o julgamento dos embargos pelo juiz federal brasileiro, se for submetida ao procedimento de homologação de sentença estrangeira pelo STJ.
} 
Supremo Tribunal Federal, na prática, torna-se inviável impor ao Estado requerente que aguarde o esgotamento de todos os incidentes processuais ${ }^{550}$.

Assim, embora seja aparentemente a medida mais garantista, uma vez que permite contenciosidade plena, o auxílio direto, dado o completo hiato na legislação brasileira, é a medida que mais pode gerar conflitos de ordem prática; poderá ser a medida em que o concernido terá mais dificuldade de exercitar o contraditório e a ampla defesa, colocando-o em completa situação de desigualdade em relação aos acusados em outros processos inteiramente nacionais.

Há de se questionar se tal realidade não feriria a garantia da igualdade, em sua vertente material, não somente a da igualdade entre as partes de um processo, mas, também, a da igualdade entre todos aqueles que se encontram em posição de acusado.

A despeito dessas dificuldades de ordem prática e concreta, mesmo assim entendemos que o auxílio direto, além de ter um procedimento mais célere e menos burocrático em relação à carta rogatória ${ }^{551}$, permite, em tese, maior controle do ato solicitado pelo concernido, que poderá exercer a ampla defesa e o contraditório com maior e efetiva amplitude. Trata-se, a nosso ver, do modelo de cooperação jurídica internacional que mais consegue garantir eficiência sem colocar em segundo plano os direitos fundamentais do concernido.

\footnotetext{
${ }^{550}$ De que adianta recorrer se, ao final, a decisão poderá não ser cumprida pelo Estado requerido? Neste ponto, ausente estaria o caráter provisório da medida, que, uma vez concedida, dificilmente poderia ser revogada no caso de auxílio direto (na carta rogatória, como não há análise de mérito, tal questão perde o sentido).

${ }^{551} \mathrm{O}$ auxílio direto é sem sombra de dúvidas menos burocrático, na medida em que o pedido tramita diretamente entre Autoridades Centrais e não se submete ao prévio juízo de delibação. Ser menos burocrático, contudo, não significa necessariamente ser mais rápido. A nacionalização do pedido permite maior cognição e contenciosidade estendida, cabendo às partes todos os recursos inerentes, podendo levar tempo até que a medida torne-se definitiva para ser devolvida ao Estado requerente.
} 


\section{CONCLUSÕES}

1. O estudo foi desenvolvido para abordar o tema da cooperação jurídica internacional em matéria penal sob a perspectiva do devido processo legal e, a partir desse enfoque, identificar conflitos que eventualmente surgem dos pedidos de assistência jurídica para cumprimento de medidas cautelares patrimoniais penais.

2. A globalização e o fortalecimento do sistema internacional de direitos humanos impuseram um contraponto ao tradicional conceito de soberania, que, hoje, encontra-se em processo de flexibilização. Consequentemente, ainda que haja entraves a serem superados, a soberania tende a ser mais relacional que insular, marcada menos pela capacidade de autodefesa e mais pela capacidade de os Estados agirem como players globais, participando dos regimes internacionais de cooperação.

5. Cooperação Jurídica Internacional em matéria penal pressupõe, em termos gerais, compromisso de assistência mútua - colaboração - entre diferentes Estados soberanos ou entre Estados e organismos ou tribunais internacionais, para a consecução de medidas, atos ou providências de natureza processual, extraprocessual ou de investigação, que são cumpridos no interesse de uma jurisdição - o Estado requerente - por órgãos pertencentes a outra jurisdição - o Estado requerido.

6. A cooperação jurídica internacional não representa relação de interesse meramente interestadual. Trata-se de relação processual e de caráter transnacional, porque envolve sistemas jurídico-processuais de Estados diferentes. Os instrumentos de cooperação jurídica internacional desenvolvem-se no âmbito interno dos países por meio do chamado processo cooperacional, que, como qualquer outro processo, está sujeito às balizas do due process of law.

6.1. A cooperação jurídica internacional em matéria penal está inserida no contexto do chamado Direito Processual Penal Internacional, estudo que propõe um novo enfoque ao direito processual em decorrência de sua projeção externa, além dos limites de um único Estado.

6.2. No processo cooperacional, devem ser reconhecidos como parte não apenas os Estados envolvidos na cooperação, mas também a pessoa atingida pela medida solicitada em assistência jurídica internacional: o concernido, que se vincula aos Estados 
requerente e requerido, formando uma relação processual trilateral. Os direitos fundamentais do concernido incidem no processo cooperacional da mesma maneira como incidem nos processos internos dos países.

6.3. Dois movimentos opostos impulsionam hoje o desenvolvimento da cooperação jurídica internacional, influenciando o processo cooperacional: de um lado, a necessidade de intensificar a cooperação na luta contra o crime - eficiência - e, de outro lado, a consciência de que os direitos fundamentais devem se impor como referência e limite à cooperação internacional em matéria penal - garantismo.

Esses dois movimentos desenvolvem-se através de vetores, correntes que operam no campo normativo e doutrinário internacional, impulsionando o processo cooperacional a uma maior eficiência sem desprezo das garantias fundamentais do concernido.

Eficiência e garantismo não são expressões antagônicas no processo penal, mas expressões que se somam, completam-se. Por isso, os vetores à eficiência do processo cooperacional encontram limite na medida de atuação dos vetores de garantia, atingindo-se o equilíbrio necessário, isto é, que não represente cooperar acima de qualquer custo nem permitir que a cooperação seja inviabilizada pela adoção cega às garantias do concernido.

7. Por efeito da globalização, vemos a internacionalização do Direito e do crime. Vive-se diante de uma criminalidade que não respeita fronteiras geográficas. No momento em que se mostrou difícil reprimir o crime no âmbito interno dos países, a comunidade internacional passou a perseguir, também, os efeitos e proventos do crime, através, por exemplo, do cumprimento de medidas cautelares patrimoniais para bloqueio e confisco de bens do acusado existentes no exterior. Nesse contexto, os tratados internacionais tiveram papel relevante, porque somente a partir da cooperação jurídica internacional seria possível atingir tal intento.

8. Medidas cautelares patrimoniais no processo penal asseguram resultado útil e eficaz à futura sentença penal condenatória no que toca ao efeito automático de tornar certa a obrigação de reparar o dano, bem como ao efeito de perdimento dos proventos do crime e dos bens obtidos com os proventos da infração.

Comparando o modelo de medidas cautelares patrimoniais de acordo com o direito processual penal brasileiro com o regime de medidas cautelares patrimoniais penais da Itália e Portugal, por exemplo - que são os países dos quais o Brasil mais demanda em matéria 
de cooperação jurídica e os países de onde o Brasil mais recebe pedidos de assistência internacional -, não é possível ignorar as diferentes opções de tutela cautelar penal.

Por existirem distintas opções, o estranhamento do tratamento dispensado pelo ordenamento jurídico de um Estado nessa matéria de direito processual penal pode deflagrar, perante outro Estado, argumentos contrários ao atendimento do pedido de assistência jurídica penal, inviabilizando o fluxo cooperacional. A tensão entre os diferentes sistemas jurídicos ainda hoje dificulta o cumprimento de medidas cautelares patrimoniais no âmbito da assistência jurídica em matéria penal.

Tal tensão tende a ser menos tormentosa à medida que se desenvolve a assistência jurídica internacional. Do tradicional paradigma do soberanismo ao da mútua confiança, quando menor a intolerância externa e a outros modelos processuais e a exigência por correspondência entre os modelos para a consecução dos pleitos cooperacionais, maior será a aproximação entre os sistemas, por isso, menor relevância terão eventuais diferenças de opções de medidas cautelares patrimoniais.

De qualquer maneira, como nunca existirá correspondência exata entre os sistemas jurídicos, mostra-se mais proveitoso pautar os pleitos cooperacionais em relação a medidas cautelares patrimoniais nos standards mínimos de garantia estabelecidos pelos tratados internacionais humanitários, porque fixam pontos de contato entre os sistemas.

9. Medidas cautelares patrimoniais penais em assistência jurídica são cumpridas no Brasil através dos instrumentos da carta rogatória e do auxílio direto - este último surgido mais recentemente como solução à proibição de cumprimento de cartas rogatórias de caráter executório, o que inviabilizava grande maioria dos pleitos cooperacionais por medidas cautelares recebidos pelo Brasil.

A busca, pelos Tribunais pátrios, de proteção da soberania desemboca muitas vezes em aversão a qualquer modelo estrangeiro que não se assemelhe à opção brasileira de medidas cautelares patrimoniais penais. Essa real impermeabilidade dos Tribunais Superiores frente aos pedidos de assistência jurídica é apontada pela doutrina como espécie de "xenofobia judiciária".

10. No quarto e último capítulo, vimos que existem inúmeras questões que surgem quando se desloca as medidas cautelares patrimoniais penais no contexto da cooperação jurídica internacional. Os temas mais tormentosos, analisados no capítulo, 
dizem respeito à suposta autonomia do processo cautelar e do processo estrangeiro, à referibilidade das medidas em relação à exigência de dupla incriminação, à legalidade ativa, quer para requerer assistência internacional, quer para requerer a medida cautelar patrimonial, e ao âmbito de atuação do concernido.

A partir dessas análises, é possível concluir que a ausência de uma lei geral de cooperação no Brasil dificulta - e muito - o cumprimento de medidas cautelares patrimoniais em assistência jurídica internacional. O regramento jurídico da matéria é desuniforme, consequentemente a tramitação dos pedidos de cooperação submete-se a um emaranhado de normas constitucionais e infraconstitucionais.

$\mathrm{Na}$ ausência de um regramento uniforme e definitivo, a jurisprudência dos Tribunais superiores tenta suprir a lacuna legislativa, ziguezagueando em um vai-e- -vem de posicionamentos, ora congruentes, ora desconexos e contraditórios.

O modelo de delibação adotado pelo Estado brasileiro às cartas rogatórias engessa sobremaneira o controle e a participação do concernido em relação às medidas cautelares patrimoniais penais cumpridas em cooperação passiva. Por isso, impõe-se o incentivo ao maior emprego e aceitação do auxílio direto, que permite contenciosidade plena e ampla cognição do juiz nacional em relação ao mérito do pedido, sendo, por isso, o instrumento mais garantista de cooperação.

Apesar disso, o auxílio direto ainda é medida que pode gerar muitos conflitos de ordem doutrinária e prática, dado o completo hiato legislativo quanto ao seu procedimento. Urge, portanto, ser regulamentado no Brasil, pois, desta forma, sendo mais célere e menos burocrático, garantirá real eficiência no atendimento dos pleitos cooperacionais e, por outro lado, permitirá controle ainda maior pelo concernido em relação à constrição judicial contra seus bens. 


\section{REFERÊNCIAS}

\section{Obras Citadas}

ABADE, Denise Neves. Direitos fundamentais na cooperação jurídica internacional: extradição, assistência jurídica, execução de sentença estrangeira e transferência de presos. São Paulo: Saraiva, 2013.

ACCIOLY, Hildebrando; NASCIMENTO E SILVA, G. E.; CASELLA, Paulo Borba. Manual de direito internacional público. 18. ed. São Paulo: Saraiva, 2010.

ADVOCACIA-GERAL DA UNIÃO. Disponível em: <www.agu.gov.br>. Acesso em: 14 jul. 2013.

AMICIS, Gaetano de. Cooperazione giudiziaria e corruzione internazionale: verso un sistema integrato di forme e strumenti di collaborazione tra le autorità giudiziaria. Milano: Giuffrè, 2007.

ARAS, Vladmir. O papel da autoridade central nos acordos de cooperação penal internacional. In: BALTAZAR JÚNIOR, Paulo José; LIMA, Luciano Flores de (Orgs.). Cooperação jurídica internacional em matéria penal. Porto Alegre: Verbo Jurídico, 2010.

ARAÚJO, Nádia de. As novidades da Resolução n. 9 do STJ, que dispõe sobre cartas rogatórias e sentenças estrangeiras. Disponível em: <http://www.dip.com.br>. Acesso em: jul. 2012.

(Coord.). Cooperação jurídica internacional no Superior Tribunal de Justiça: comentários à Resolução nº 9/2005. Rio de Janeiro: Renovar, 2010.

ARAÚJO JÚNIOR, João Marcelo de. Introdução à teoria geral do direito penal Internacional. In: KUEHNE, Maurício (Org.). Ciência penal: coletânea de estudos: homenagem à Alcides Munhos Netto. Curitiba: JM, 1999.

ARRUDA, Eloisa de Sousa. As medidas cautelares reais no processo penal brasileiro. MPMG Jurídico, Belo Horizonte, v. 1, n. 3, p. 52-53, dez./jan. 2005/2006.

ASSIS, Araken de. A eficácia civil da sentença penal. São Paulo: Ed. Revista dos Tribunais, 1993. 
ASSIS, Araken de. Liquidação do dano. In: MENDES, Gilmar Ferreira; STOCO, Rui (Orgs.). Atos, fatos, negócios jurídicos e bens. São Paulo: Ed. Revista dos Tribunais, 2001. (Coleção doutrinas essenciais: direito civil, parte geral; v. 4).

ASTILLEJO MANZANARES, Raquel. El nuevo tratamiento de las medidas cautelares en el proceso penal. Revista de Derecho y Proceso Penal, Navarra, v. 2, n. 26, p.13-23, 2011.

BADARÓ, Gustavo Henrique Righi Ivahy. Correlação entre acusação e sentença. 2. ed. São Paulo: Ed. Revista dos Tribunais, 2010.

Medidas cautelares patrimoniais no processo penal. In: VILARDI, Celso Sanchez; PEREIRA, Flávia Rahal Bresser; DIAS NETO, Theodomiro (Coords.). Direito penal econômico: crimes econômicos e processo penal. São Paulo: Saraiva, 2008.

Ônus da prova no processo penal. São Paulo: Ed. Revista dos Tribunais, 2003.

; BOTTINI, Pierpaolo Cruz. Lavagem de dinheiro: aspectos penais e processuais penais. São Paulo: Ed. Revista dos Tribunais, 2012.

BALTAZAR JÚNIOR, Paulo José; LIMA, Luciano Flores de (Orgs.). Cooperação jurídica internacional em matéria penal. Porto Alegre: Verbo Jurídico, 2010.

BARDAJÍ, Salvador Viada. Coordinación de procedimientos en casos conexos o cuando tengan jurisdicción distintos tribunales: transferencia de procedimientos. Revista del Ministerio Fiscal, n. 9, 2009.

BASSIOUNI, Cherif. El derecho penal internacional: historia, objeto y contenido. Anuario de Derecho Penal y Ciencias Penales, Madrid: t. 35, fasc. 1, jan./abr.1982.

BECHARA, Fábio Ramazzini. Cooperação jurídica internacional em matéria penal: eficácia da prova produzida no exterior. São Paulo: Saraiva, 2011.

; ARAÚJO, Marcilândia. Medidas de cooperação reais. In: FERNANDES, Antonio Scarance; ZILLI, Marcos Alexandre Coelho (Coord.). Direito processual penal internacional. São Paulo: Atlas, 2013.

BEDAQUE, José Roberto dos Santos. Tutela cautelar e tutela antecipada: tutelas sumárias e de sistematização. 5. ed. São Paulo: Malheiros Ed., 2009.

BITENCOURT, Cezar Roberto. Tratado de direito penal: parte geral. 16. ed. São Paulo: Saraiva, 2011. v. 1. 
BRUNO, Aníbal. Direito penal: parte geral. Rio de Janeiro: Forense, 1966. t. 3.

BUONO, Carlos Eduardo de Athayde; BENTIVOGLIO, Antônio Tomás. A reforma processual penal italiana - reflexos no Brasil: novos institutos processuais: procedimentos e ritos abreviados: a influência anglo-saxônica. São Paulo: Ed. Revista dos Tribunais, 1991.

CALAMANDREI, Piero. Introduzione allo studio sistematico dei provvedimenti cautelari. Padova: CEDAM, 1936.

CARNELUTTI, Francesco. Lecciones sobre el proceso penal. Buenos Aires: Ediciones Jurídicas Europa-América, 1950.

Principi del processo penale. Napoli: Morano, 1960.

CARO CORIA, Dino. El principio de "ne bis in idem" en la jurisprudencia del Tribunal Constitucional. Revista Brasileira de Ciências Criminais, São Paulo, ano 15, n. 66, maio/jun. 2007.

CARVALHO, Olímpio. Reparação de danos provenientes de atos ilícitos. In: MENDES, Gilmar Ferreira; STOCO, Rui (Orgs.). Atos, fatos, negócios jurídicos e bens. São Paulo: Ed. Revista dos Tribunais, 2001. (Coleção doutrinas essenciais: direito civil, parte geral; v. 4).

CASELlA, Paulo Borba. Direito internacional pós-moderno. 2006. Tese (Titular) Faculdade de Direito da Universidade de São Paulo, São Paulo, 2006.

CASSESE, Antonio. International criminal law. 2.ed. Oxford: Oxford University Press, 2007.

Lineamenti di diritto internazionale penale: diritto processuale. Bologna: Il Mulino, 2006. v. 2.

CERVINI, Raul; TAVARES, Juarez. Princípios da cooperação judicial penal internacional no Protocolo do Mercosul. São Paulo: Ed. Revista dos Tribunais, 2000.

COLOMER HERNÁNDEZ, Ignacio. Conflictos de jurisdicción, non bis in idem y litispendencia internacional en la Unión Europea. In: ARROYO ZAPATERO, Luis; NIETO MARTIN, Adán (Coord.). El principio de ne bis in idem en el derecho penal europeo e internacional. Cuenca: Universidad de Castilla-La Mancha, 2007.

CONSOLO, Claudio. Profili della litispendencia internazionale. Rivista di Diritto Internazionale, Milano, v. 80, n. 1, p. 5-77, 1997. 
CORDANI, Dora Cavalcanti. A cooperação jurídica Internacional em matéria penal no Brasil: as cartas rogatórias e o auxílio direto - controle dos atos pela parte atingida. In: SANCHEZ VILARDI, Celso; PEREIRA, Flávia Rahal Bresser; DIAS NETO, Theodomiro (Coords.). Direito penal econômico: crimes econômicos e processo penal. São Paulo: Saraiva, 2008.

CRISSIUMA, Marcos Vidigal de Freitas. A inconstitucionalidade e ilegalidade do acordo de cooperação mútua internacional firmado entre o Brasil e os Estados Unidos da América (MLAT). Boletim IBCCRIM, São Paulo, v. 17, n. 205, p. 10-11, dez. 2009.

CRUZ, Paulo Márcio. Soberania, Estado, globalização e crise. Novos Estudos Jurídicos, São Paulo, ano 3, n. 15, p. 7-24, dez. 2002.

CRUZ, Rogério Schietti Machado. A proibição de dupla persecução penal (ne bis in idem): limites no direito brasileiro. 2007. Tese (Doutorado) - Faculdade de Direito da Universidade de São Paulo, São Paulo, 2007.

DELMANTO, Celso et al. Código Penal comentado. 6. ed. atual. e ampl. Rio de Janeiro: Renovar, 2002.

DELMANTO, Fábio Machado de Almeida. Medidas substitutivas e alternativas à prisão cautelar. 2006. Tese (Mestrado) - Faculdade de Direito da Universidade de São Paulo, 2006.

DELMANTO JÚNIOR, Roberto. As modalidades de prisão provisória e seu prazo de duração. 2. ed. Rio de Janeiro: Renovar, 2001.

DELMAS-MARTY, Mireille. O direito penal como ética da mundialização. Revista Portuguesa de Ciência Criminal, Coimbra, ano 14, n. 3, jul./set. 2004.

DE SANCTIS, Fausto Martin. Crime organizado e lavagem de dinheiro: destinação de bens apreendidos, delação premiada e responsabilidade social. São Paulo: Saraiva, 2009.

DIAS, Jorge de Figueiredo. Direito processual penal. Coimbra: Coimbra Ed., 2004.

DIPP, Gilson. Cartas rogatórias e cooperação jurídica internacional. In: MANUAL de cooperação jurídica internacional e recuperação de ativos: cooperação em matéria penal. Brasília: Ministério da Justiça, 2008.

DOTTI, René Ariel. Curso de direito penal: parte geral. 2. ed. Rio de Janeiro: Forense, 2005. 
EUR-Lex. Decisão-Quadro 2003/577/JAI do Conselho de 22 de Julho de 2003. Disponível em: $<$ http://eur-lex.europa.eu/LexUriServ/LexUriServ.do?uri=OJ:L:2003:196:0045:0055:PT:PDF>. Acesso em: $21 \mathrm{dez} .2013$.

FASANO, Renata Rossini. A competência repressiva universal no direito internacional penal. 2011. Dissertação (Mestrado) - Faculdade de Direito da Universidade de São Paulo, São Paulo, 2011.

FERNANDES, Antonio Scarance. O direito processual penal internacional. In: FERNANDES, Antonio Scarance; ZILLI, Marcos Alexandre Coelho (Coords.). Direito processual penal internacional. São Paulo: Atlas, 2013.

. O equilíbrio entre eficiência e o garantismo e o crime organizado. Revista Brasileira de Ciências Criminais, São Paulo, ano 16, n. 70, p. 226-268, jan./fev. 2008.

. O papel da vítima no processo criminal. São Paulo: Malheiros Ed., 1995.

Processo penal constitucional. 6. ed. atual. rev. São Paulo: Ed. Revista dos Tribunais, 2010.

Reflexões sobre as noções de eficiência e de garantismo no processo penal. In: FERNANDES, Antonio Scarance; ALMEIDA, José Raul Gavião de; MORAIS, Maurício Zanoide de (Coords.). Sigilo no processo penal: eficiência e garantismo. São Paulo: Ed. Revista dos Tribunais, 2008.

Teoria geral do procedimento e o procedimento no processo penal. São Paulo: Ed. Revista dos Tribunais, 2005.

; ZILLI, Marcos Alexandre Coelho (Coords.). Direito processual penal internacional. São Paulo: Atlas, 2013.

FERRAJOLI, Luigi. Direito e razão: teoria do garantismo penal. Tradução Ana Paula Zomer Sica et al. São Paulo: Ed. Revista dos Tribunais, 2010.

GARCÍA SÁNCHEZ, Beatriz. La extradición en el ordenamiento interno español, internacional y comunitario. Granada: Comares, 2005.

. El principio de justicia universal en ordenamiento interno y internacional. Disponível em: <http://eciencia.urjc.es>. Acesso em: 30 ago. 2013.

GEMAQUE, Silvio Cezar Arouk. A necessária influência do processo penal internacional no processo penal brasileiro. 2010. Tese (Doutorado) - Faculdade de Direito da Universidade de São Paulo, São Paulo, 2010. 
GENRO, Tarso. A cooperação jurídica internacional e o propósito deste manual. In: MANUAL de cooperação jurídica internacional e recuperação de ativos: cooperação em matéria penal. Brasília: Ministério da Justiça, 2008.

GIMENES, Marta Cristina Cury Saad. As medidas assecuratórias do Código de Processo Penal como forma de tutela cautelar destinada à reparação do dano causado pelo delito. 2007. Tese (Doutorado) - Faculdade de Direito da Universidade de São Paulo, São Paulo, 2007.

. Propostas para a recuperação de ativos. Revista Getúlio, set. 2008.

GOMES FILHO, Antônio Magalhães. Medidas cautelares e princípios constitucionais. In: FERNANDES, Og (Coord.). Medidas cautelares no processo penal: prisões e suas alternativas - comentários à Lei 12.403, de 04.05.2011. São Paulo: Ed. Revista dos Tribunais, 2011.

Presunção de inocência e prisão cautelar. São Paulo: Saraiva, 1991.

GONÇALVES, Marianna Moura. Prisão e outras medidas cautelares pessoais à luz da proporcionalidade. 2001. Dissertação (Mestrado) - Faculdade de Direito da Universidade de São Paulo, São Paulo, 2001.

GRINOVER, Ada Pellegrini. O processo em evolução. 2. ed. Rio de Janeiro: Forense Universitária, 1998.

Processo penal transnacional: linhas evolutivas e garantias processuais. Revista Brasileira de Ciências Criminais, São Paulo, v. 3, n. 9, p. 40-83, jan./mar. 1995.

HABERLE, Peter. O Estado constitucional cooperativo. Rio de Janeiro: Renovar, 2007.

HAIDAR, Rodrigo. Réus do mensalão insistem em oitivas no exterior. Conjur, São Paulo, 16 fev. 2009. Disponível em: <http://www.conjur.com.br/2009-fev-16/reus-mensalaoinsistem-oitivas-testemunhas-exterior>. Acesso em: 27 dez. 2013.

HOUAISS, Antônio; VILLAR, Mauro Salles. Dicionário Houaiss da língua portuguesa. Rio de Janeiro: Objetiva, 2001.

HUNGRIA, Nelson. Comentários ao Código Penal. Rio de Janeiro: Forense, 1942. v. 2.

JAPIASSÚ, Carlos Eduardo Adriano. O Tribunal Penal Internacional. Rio de Janeiro: Lumen Juris, 2004. 
JESCHECK, Hans-Henrich. O objeto do direito penal internacional e sua mais recente evolução. Revista de Direito Penal, n. 6, p. 7-20, abr./jun. 1972.

JO, Hee Moon; SILVA SOBRINHO, Marcelo da. Soberania no direito internacional: evolução ou revolução? Revista de Estudos Jurídicos UNESP, Franca, v. 9, n. 13, p. 239278, jan./dez. 2004.

KALB, Luigi. La "ricostruzione orale" del fato tra "efficienza" ed "efficacia" del processo penale. Torino: G. Giappichelli, 2005.

LEITE, Larissa. Medidas patrimoniais de urgência no processo penal: implicações teóricas e práticas. Rio de Janeiro: Renovar, 2011.

LESSA, Luiz Fernando Voss Chagas. Persecução penal e cooperação internacional direta pelo Ministério Público. Rio de Janeiro: Lumen Juris, 2013.

LEWANDOWSKI, Ricardo Enrique. Globalização, regionalização e soberania. São Paulo: Juarez de Oliveira, 2003.

LIMA, Marcellus Polastri. Algumas medidas preventivas, mas não cautelares, no processo penal. In: Lima, Marcellus Polastri (Coord.). Estudos criminais em homenagem a Weber Martins Batistas. Rio de Janeiro: Lumen Juris, 2008.

LOPES JR., Aury. Direito processual penal e sua conformidade constitucional. 6. ed. Rio de Janeiro: Lumen Juris, 2010. v. 1.

Introdução crítica ao processo penal: fundamentos da instrumentalidade constitucional. 4. ed. Rio de Janeiro: Lumen Juris, 2006.

LYRA, Roberto. Comentários ao Código Penal. Rio de Janeiro: Forense, 1942. v. 2.

MACHADO, Antônio Cláudio da Costa. Considerações sobre a função cautelar: tertium genus, "direito substancial de cautela" e preventividade cautelar. Revista EPD, São Paulo, v. 2, n. 3, p. 13-26, out./nov. 2006.

MACHADO, Fábio Guedes de Paula. Prescrição penal: prescrição funcionalista. São Paulo: Ed. Revista dos Tribunais, 2000.

MACHADO, Maíra Rocha. Cooperação penal internacional e o intercâmbio de informações bancárias: as decisões do STF sobre quebra de sigilo em cartas rogatórias. In: MACHADO, Maíra Rocha; REFINETTI, Domingos Fernando (Orgs.). Lavagem de dinheiro e recuperação de ativos: Brasil, Nigéria, Reino Unido e Suíça. São Paulo: Quartier Latin, 2006. 
MACHADO, Maíra Rocha; REFINETTI, Domingos Fernando (Orgs.). Lavagem de dinheiro e recuperação de ativos: Brasil, Nigéria, Reino Unido e Suíça. São Paulo: Quartier Latin, 2006.

MADRUGA, Antenor. O Brasil e a jurisprudência do STF na Idade Média da cooperação jurídica internacional. In: MACHADO, Maíra Rocha; REFINETTI, Domingos Fernando (Orgs.). Lavagem de dinheiro e recuperação de ativos: Brasil, Nigéria, Reino Unido e Suíça. São Paulo: Quartier Latin, 2006.

MAIA, Rodolfo Tigre. O princípio do ne bis in idem e a Constituição brasileira de 1988. Boletim Científico - Escola Superior do Ministério Público da União, Brasília, ano 4, n. 16, p. 11-75, jul./set. 2005.

MANUAL de cooperação jurídica internacional e recuperação de ativos: cooperação em matéria penal. Brasília: Ministério da Justiça, 2008.

MARQUES, José Frederico. Elementos de direito processual penal. Campinas: Bookseller, 2002. v. 1.

MARQUES, Silvio Antônio. Cooperação jurídica com a Suíça. In: BALTAZAR JÚNIOR, Paulo José; LIMA, Luciano Flores de (Orgs.). Cooperação jurídica internacional em matéria penal. Porto Alegre: Verbo Jurídico, 2010.

MENDES, Gilmar Ferreira; STOCO, Rui (Orgs.). Atos, fatos, negócios jurídicos e bens. São Paulo: Ed. Revista dos Tribunais, 2001. (Coleção doutrinas essenciais: direito civil, parte geral; v. 4).

MINISTÉRIO DA JUSTIÇA. Disponível em: <http://portal.mj.gov.br >. Acesso em: 05 jul.; 24 ago. 2013.

MORO, Sérgio Fernando. Cooperação jurídica internacional em casos criminais: considerações gerais. In: BALTAZAR JÚNIOR, Paulo José; LIMA, Luciano Flores de (Orgs.). Cooperação jurídica internacional em matéria penal. Porto Alegre: Verbo Jurídico, 2010.

MOURA, Maria Thereza Rocha de Assis. Justa causa para a ação penal: doutrina e jurisprudência. São Paulo: Ed. Revista dos Tribunais, 2001.

NORONHA, Edgard Magalhães. Direito penal. 14. ed. São Paulo: Saraiva, 1977. v. 1.

NUCCI, Guilherme de Souza. Código Penal comentado. São Paulo: Ed. Revista dos Tribunais, 2000. 
PIOVESAN, Flavia. Direitos humanos e o direito constitucional internacional. 5. ed. São Paulo: Max Limonad, 2002.

; GOMES, Flávio (Coords.). O sistema interamericano de proteção dos direitos humanos e o direito brasileiro. São Paulo: 2000.

PISANI, Mario. Ne bis in idem y cooperación judicial europea. In: ARROYO ZAPATERO, Luis; NIETO MARTIN, Adán (Coord.). El principio de ne bis in idem en el derecho penal europeo e internacional. Cuenca: Universidad de Castilla-La Mancha, 2007. et al. Manuale di procedura penale. Bologna: Monduzzi, 1994.

REALE JÚNIOR, Miguel. Instituições de direito penal: parte geral. 3. ed. Rio de Janeiro: Forense, 2009.

RITTA, Cristiano Ribeiro. Aspectos da competência jurisdicional penal internacional. Prismas: direito, políticas públicas e mundialização. Brasília, v. 3, n.1, p. 125-147, jan./jun. 2006.

ROSA, Alexandre Morais da. Garantismo jurídico e controle de constitucionalidade material. Rio de Janeiro: Lumen Juris, 2005.

SÁNCHEZ RIOS, Rodrigo. Da limitada utilização do arresto cumulado com medida de especialização de hipoteca legal no processo penal pátrio. Revista do Curso de Mestrado em Direito, Presidente Prudente, v. 2, n. 2, p. 317-329, dez. 2001.

SATZGER, Helmut; ZIMMERMANN, Frank. Dos modelos tradicionais de cooperação judicial ao princípio do reconhecimento mútuo: novos desdobramentos do verdadeiro paradigma da Cooperação Europeia em matéria penal. In: BALTAZAR JÚNIOR, Paulo José; LIMA, Luciano Flores de (Orgs.). Cooperação jurídica internacional em matéria penal. Porto Alegre: Verbo Jurídico, 2010.

SCHUNEMANN, Bernd. As bases do processo penal transnacional. Revista Brasileira de Ciências Criminais, São Paulo, v. 19, n. 90, p. 189-209, maio/jun. 2011.

SENADO FEDERAL. Disponível em: <www.senado.gov>. Acesso em: 14 jul. 2013.

SILVA, Ricardo Perlingeiro Mendes da. Cooperação jurídica internacional e auxílio direto. Revista CEJ, Brasília, n. 32, p. 75-79, jan./mar. 2006.

SILVA SANCHÉZ, Jesus-Maria. El derecho penal ante la globalización y la integración supranacional. Revista Brasileira de Ciencias Criminais, São Paulo, v. 6, n. 24, p. 65-78, out./dez. 1998. 
SLAUGHTER, Anne-Marie. Sovereighty and power in a networked world order. Stanford Journal of International Law, v. 40, p. 283-327, 2004.

SOARES, Mário Lúcio Quintão. Mercosul, direitos humanos, globalização e soberania. 2. ed. Belo Horizonte: Del Rey, 1999.

SOUZA, Carolina Yumi de. Os caminhos percorridos no combate ao crime. Revista Getúlio, set. 2008.

Cooperação jurídica internacional em matéria penal: considerações práticas. Revista Brasileira de Ciências Criminais, São Paulo, v. 16, n. 71, p. 297-325, mar./abr. 2008.

A defesa na cooperação jurídica internacional: reflexões preliminares. Boletim IBCCRIM, São Paulo, v. 18, n. 214, p. 14-15, set. 2010.

SOUZA, Solange Mendes de. Cooperação jurídica penal no Mercosul: novas possibilidades. Rio de Janeiro: Renovar, 2001.

STEINER, Sylvia Helena de Figueiredo. A Convenção Americana sobre Direitos Humanos e sua integração ao processo penal brasileiro. São Paulo: Ed. Revista dos Tribunais, 2000.

SUPERIOR TRIBUNAL DE JUSTIÇA. Disponível em: <www.stj.jus.br>. Acesso em: 07 set. 2013.

TARZIA, Giuseppe. Procedimenti cautelari. Padova: Casa Editrice Dott. Antonio Milano, 1990.

THEODORO JÚNIOR, Humberto. Processo cautelar. 19. ed. São Paulo: Livr. e Editora Universitária de Direito, 2000.

TOFFOLI, José Antonio Dias; CESTARI, Virgínia Charpinei Junger. Mecanismos da cooperação jurídica internacional no Brasil. In: MANUAL de cooperação jurídica internacional e recuperação de ativos: cooperação em matéria penal. Brasília: Ministério da Justiça, 2008.

TONINI, Paolo. Manuale breve diritto processuale penale: tutto il programma d'esame con domande e risposte commentate. Milano: Giuffrè, 2009.

TORNAGHI, Hélio. Instituições de processo penal. 2. ed. São Paulo: Saraiva, 1978. v. 3. 
TOURINHO FILHO, Fernando da Costa. Processo penal. 34. ed. São Paulo: Saraiva, 2012. v. 2.

TROTTA, Sandro Brescovit; FERREIRA, Luciano Vaz. Da obrigatoriedade de cooperar e os recursos cabíveis em casos de descumprimento de tratado internacional. In: BALTAZAR JÚNIOR, Paulo José; LIMA, Luciano Flores de (Orgs.). Cooperação jurídica internacional em matéria penal. Porto Alegre: Verbo Jurídico, 2010.

TUCCI, Rogério Lauria. Direitos e garantias individuais no processo penal brasileiro. 2. ed. São Paulo: Ed. Revista dos Tribunais, 1993.

; DELMANTO JÚNIOR, Roberto. Sistematização das medidas cautelares processuais penais. Revista do Advogado, São Paulo, v. 24, n. 78, p. 111-122, set. 2004.

VERGUEIRO, Luiz Fabricio Thaumaturgo. Apontamentos gerais sobre a cooperação jurídica internacional e suas modalidades. In: FERNANDES, Antonio Scarance; ZILLI, Marcos Alexandre Coelho (Coord.). Direito processual penal internacional. São Paulo: Atlas, 2013.

Implementação da cooperação jurídica internacional vertical. 2012. Tese (Doutorado) - Faculdade de Direito da Universidade de São Paulo, São Paulo, 2012.

VERVAELE, John A.E. El principio ne bis idem en Europa: el Tribunal de Justicia y los derechos fundamentales en el espacio judicial europeo. Nueva Doctrina Penal, Buenos Aires, n. 1, p. 287-308, 2005.

VIEIRA, Oscar Vilhena; LUZ FILHO, José Francisco Sieber. Soberania e direitos humanos: reflexos do caso Pinochet I. Revista do ILANUD, São Paulo, n. 17, 2001.

VILARDI, Celso Sanchez; PEREIRA, Flávia Rahal Bresser; DIAS NETO, Theodomiro (Coords.). Direito penal econômico: crimes econômicos e processo penal. São Paulo: Saraiva, 2008.

VILARES, Fernanda Regina. Cooperação internacional em matéria penal e a recuperação de ativos. In: FERNANDES, Antonio Scarance; ZILLI, Marcos Alexandre Coelho (Coord.). Direito processual penal internacional. São Paulo: Atlas, 2013.

WEBER, Patrícia Nuñez. A cooperação jurídica internacional em medidas processuais penais. Porto Alegre: Verbo Jurídico, 2011.

YAÑEZ M. Juan. Medidas cautelares reales. In: ALVEAR V., María Soledad (Coord.). El nuevo proceso penal chileno. Concepción: Impresos Andalién, 2000. 
ZAFFARONI, Eugenio Raúl; PIRANGELI, José Henrique. Manual de direito penal brasileiro - parte geral. 2. ed. São Paulo: Ed. Revista dos Tribunais, 1999.

ZILLI, Marcos Alexandre Coelho. Os caminhos da internacionalização do processo penal. In: In: FERNANDES, Antonio Scarance; ZILLI, Marcos Alexandre Coelho (Coord.). Direito processual penal internacional. São Paulo: Atlas, 2013.

. Cooperação e auxílio com o Tribunal Penal Internacional. Boletim IBCCRIM, São Paulo, v. 162, maio 2006.

\section{Obras Consultadas}

ABADE, Denise Neves. Persecução penal contemporânea dos crimes de colarinho branco: os crimes contra o sistema financeiro nacional e a assistência legal internacional. In: ROCHA, João Carlos de Carvalho; HENRIQUES FILHO, Tacísio Humberto Parreiras; CAZETTA, Ubiratan (Orgs.). Crimes contra o Sistema Financeiro Nacional: 20 anos da Lei n. 7.492/86. Belo Horizonte: Del Rey, 2006. p. 129-172.

ABBOTT, Kenneth W.; SNIDAL, Duncan. pathways to international cooperation. In: BENVENISTI, Eyal; HIRSCH, Moshe (Eds.). The impact of international law on international cooperation: theoretical perspectives. Cambridge University Press, 2004.

ALMEIDA, Carlota Pizarro de. A cooperação judiciária internacional. In: PALMA, Maria Fernanda (Coord.). Jornadas de Direito Processual Penal e Direitos Fundamentais. Lisboa: Almedina.

AMBOS, Kai. Cooperação judiciária penal na Europa. In: BALTAZAR JÚNIOR, Paulo José; LIMA, Luciano Flores de (Org.). Cooperação jurídica internacional em matéria penal. Porto Alegre: Verbo Jurídico, 2010.

A nova Corte Internacional. O difícil equilíbrio entre uma persecução penal eficiente e a realpolitik. Boletim IBCCRIM. São Paulo, v. 70, setembro-esp, 1998.

Es el procedimiento penal internacional "adversarial", "inquisitivo" o mixto? Revista Brasileira de Ciências Criminais, São Paulo, n. 57, nov./dez. 2005.

. Processo penal europeu: preservação das garantias e direitos individuais. Rio de Janeiro: Lumen Juris, 2008.

AMODIO, Ennio. Processo penale, diritto europeo e common law: dal rito inquisitorio al giusto processo. Milano: Giuffrè, 1982. 
ANSELMO, Márcio Adriano. Cooperação internacional em matéria penal no âmbito do Mercosul: autonomia do Protocolo de San Luis. In: BALTAZAR JÚNIOR, Paulo José; LIMA, Luciano Flores de (Org.). Cooperação jurídica internacional em matéria penal. Porto Alegre: Verbo Jurídico, 2010.

ARAÚJO, Nádia de. A importância da cooperação jurídica internacional para a atuação do estado brasileiro no plano interno e internacional. In: MANUAL de cooperação jurídica internacional e recuperação de ativos: cooperação em matéria penal. Brasília: Ministério da Justiça, 2008.

; SALLES, Carlos Alberto; ALMEIDA, Ricardo R. Cooperação interjurisdicional no Mercosul: cartas rogatórias, homologação de sentenças e laudos arbitrais e informação do Direito Estrangeiro. In: BASSO, Maristela (Org.). Mercosul: seus efeitos jurídicos, econômicos e políticos nos Estados-membros. Porto Alegre: Livr. do Advogado, 1997.

ARAÚJO JÚNIOR, João Marcelo de. Introdução à teoria geral do direito penal internacional. Ciência Penal, Curitiba, 1999.

BARCELOS, Andrea Beatriz Rodrigues de. Cooperação internacional para recuperação de ativos provenientes de lavagem de capitais. De Jure: Revista Jurídica do Ministério Público de Minas Gerais, Belo Horizonte, n. 7, jul./dez. 2006.

BEDAQUE, José Roberto dos Santos Efetividade do processo e técnica processual: tentativa de compatibilização (diretrizes para aplicação da técnica processual e superação dos óbices aos escopos do processo). Tese (Titular) - Faculdade de Direito da Universidade de São Paulo, São Paulo, 2005.

BRIGGS, Arthur. Cartas rogatórias internacionais. Rio de Janeiro: Imprensa Nacional, 1913.

CASSESE, Antonio. Existe um conflito insuperável entre soberania dos Estados e justiça penal internacional? In: CASSESE, Antonio; DELMAS-MARTY, Mireille (Orgs.). Crimes internacionais e jurisdições internacionais. Barueri, SP: Manole, 2004.

DALLARI, Dalmo de Abreu. Elementos de teoria geral do Estado. 29. ed. São Paulo: Saraiva, 2010.

DAMASKA, Mirjan R. The faces of justice and state authority: a comparative approach to the legal process. Yale University Press, 1986. 
DELMAS-MARTY, Mireille. Comparative criminal law as a necessary toll for the application of international criminal law. In: CASSESE, Antonio. The Oxford companion to international criminal justice. Oxford: Oxford University Press, 2009.

DIAS, Augusto Silva. Que direito penal precisamos nós europeus? Um olhar sobre algumas propostas recentes de constituição de um direito penal comunitário. Revista Portuguesa de Ciência Criminal, Lisboa, n. 14, 2004.

ESTELLITA, Heloisa. Integração regional e direito penal. Tese (Doutorado) - Faculdade de Direito da Universidade de São Paulo, São Paulo, 2004.

FERNANDES, Antonio Scarance; ALMEIDA, José Raul Gavião; MORAIS, Maurício Zanoide de (Coord.). Crime organizado: aspectos processuais. São Paulo: Ed. Revista dos Tribunais, 2009.

FERRAJOLI, Luigi. A soberania no mundo moderno: nascimento e crise do Estado Nacional. São Paulo: Martins Fontes, 2007.

FLETCHER, George P. The influence of the common law and civil law traditions on international criminal law. In: CASSESE, Antonio. The Oxford companion to international criminal justice. Oxford: Oxford University Press, 2009.

GASPAR, Rena Alves. O Protocolo Mercosurenho sobre medidas cautelares e o sistema jurídico brasileiro: uma pequena apreciação. Revista Brasileira de Direito Constitucional, RBDC, n. 15, jan./jun. 2010.

GOMES, Rodrigo Carneiro. O crime organizado na visão da Convenção de Palermo. 2. ed. Belo Horizonte: Del Rey, 2009.

GRINOVER, Ada Pellegrini. A iniciativa instrutória do juiz no processo penal acusatório. In: GRINOVER, Ada Pellegrini. A marcha do processo. Rio de Janeiro: Forense Universitária, 2000.

A marcha do processo. Rio de Janeiro: Forense Universitária, 2000.

HERRERA PETRUS, Christian. La obtención Internacional de pruebas: asistencia jurisdiccional en Europa. Bolonia: Publicaciones del Real Colegio de España, 2005.

HERT, Paul de. Legal procedures at the International Criminal Court: a comparative law analysis of procedural basic rights. In: HAVEMAN, Roelof; KAVRAN, Olga; NICHOLLS, Julian (Eds.). Supranational criminal law: a system sui generis. New York: Intersentia, 2003. 
IBARRA PRIETO, Félix Geraldo. Soberanía y supranacionalidad: un análisis desde la perspectiva de la integración. In: CASELLA, Paulo Borba; RAMOS, André de Carvalho. Direito internacional: homenagem a Adherbal Meira Mattos. São Paulo: Quartier Latan, 2009.

KOH, Harold Hongju. Transnational public law litigation, 1991. Faculty Scholarship Series, paper 2076. Disponível em: <http://digitalcommons.law.yale.edu>. Acessao em: 11 jul.2012.

LADEIA, André Luiz Cosme. A relativização da soberania em face da preservação dos direitos e garantias fundamentais. In: ANUARIO de Derecho Constitucional Latinoamericano. Montevideo: Fundación Konrad Adenauer, 2009.

LEWANDOWSKI, Ricardo Enrique. Direito Comunitário e soberania: algumas reflexões. Revista da Faculdade de Direito-USP, São Paulo, v. 92, 1997.

LIMA, José Antonio Farah Lopes de. Direito penal europeu. Leme: Mizuno, 2007.

LOWE, Vaughan. Jurisdiction. In: EVANS, Malcolm D. International law. $1^{\text {st }}$ ed. New York: Oxford University Press, 2003.

MACHADO, Fábio Guedes de Paula. Prescrição penal: prescrição funcionalista. São Paulo: Ed. Revista dos Tribunais, 2000.

MACHADO, Maíra Rocha. Cooperação penal internacional no Brasil: as cartas rogatórias passivas. Revista Brasileira de Ciências Criminais, São Paulo, v. 13, n. 53, p. 98-118, mar./abr. 2005.

MARTINS, Fátima Adélia. Cooperação judiciária internacional em matéria penal: a Rede Judiciária Europeia (RJE). Revista do Ministério Público de Lisboa, Lisboa, n. 100, v. 25, 2004.

MARTINS, Teresa Alves; ROMA, Mônica Quintas. Cooperação internacional no processo penal: relatório português ao congresso internacional de direito processual (Taormina, Itália, 10-17 de setembro de 1995). Revista Portuguesa de Ciência Criminal, ano 5, jul./dez. 1996.

MOTA, José Luís Lopes da. A nova lei de cooperação judiciaria internacional em matéria penal. Revista do Ministério Público, Lisboa, ano 21, n. 84, Lisboa, out./dez. 2000.

OLIVEIRA, Roberto da Silva. A dignidade da pessoa humana, a razoável duração do processo e a cooperação jurídica internacional penal: a experiência luso-brasileira. In: MIRANDA, Jorge; SILVA, Marco Antonio Marques da (Coord.). Tratado luso-brasileiro da dignidade humana. 2. ed. São Paulo: Quartier Latin, 2009. p. 549-566. 
PEREIRA NETO, Pedro Barbosa. Cooperação penal internacional nos delitos econômicos. Revista Brasileira de Ciências Criminais, São Paulo, v. 13, n. 54, p.153-168, maio/jun. 2005.

PERRONE-MOISÉS, Claudia. A relação entre tribunais nacionais e tribunais penais internacionais. Boletim IBCCRIM, São Paulo, v. 8, n. 91, p. 13-14, jun. 2000.

PERUCHIN, Marcelo Caetano Guazzelli. Legitimação ativa do cidadão envolvido em atos de cooperação judicial penal internacional. In: WUNDERLICH, Alexandre (Coord.). Política criminal contemporânea: criminologia, direito penal e direito processual penal; homenagem do Departamento de Direito Penal e Processual Penal pelos 60 anos da Faculdade de Direito da PUC/RS. Porto Alegre: Livr. do Advogado, 2008. p. 319-331.

PRADO, Geraldo. Excepcionalidade da prisão provisória. In: FERNANDES, Og (Coord.). Medidas cautelares no processo penal: prisões e suas alternativas - comentários à Lei 12.403, de 04.05.2011. São Paulo: Ed. Revista dos Tribunais, 2011.

RÁO, Vicente. O direito e a vida dos direitos. 5.ed. São Paulo: Ed. Revista dos Tribunais, 1999.

SANCHEZ, Rodrigo Elian. Onze de setembro: relevância da cooperação judiciária internacional. Revista da Faculdade de Direito-USP, São Paulo, v. 97, p. 481-497, 2002.

SHIMURA. Sérgio Seiji. Arresto cautelar. 2. ed. rev. atual. São Paulo: Ed. Revista dos Tribunais, 1997.

SOARES, Mário Lúcio Quintão. A metamorfose da soberania em face da mundialização. In: PIOVESAN, Flavia. Direitos humanos, globalização econômica e integração regional: desafios do direito constitucional internacional. São Paulo: Max Limonad, 2002.

TUMA JÚNIOR, Romeu. Autoridade central e seu papel na cooperação jurídica internacional. In: MANUAL de cooperação jurídica internacional e recuperação de ativos: cooperação em matéria civil. 2. ed. Brasília: Ministério da Justiça, 2009. p.15-19.

VÁZQUEZ, Adolfo Roberto. Soberanía, supranacionalidad e integración: la cuestión en los países del Mercosul. In: ANUARIO de Derecho Constitucional Latinoamericano, Montevideo: Fundación Konrad Adenauer, 2001.

VERVAELE, John A.E. O Mercosul e a Integração Regional na América do Sul. In: BALTAZAR JÚNIOR, Paulo José; LIMA, Luciano Flores de (Org.). Cooperação jurídica internacional em matéria penal. Porto Alegre: Verbo Jurídico, 2010. 
WERLE, Gerard. Tratado de derecho penal internacional. Valencia: Tirant to Blanch, 2005.

ZILLI, Marcos Alexandre Coelho. Legem habemus. Boletim IBCCRIM, São Paulo, v. 20, n. 230, p. 4-5, jan. 2012.

; GHIDALEVICH, Fabiola Girão Monteconrado. Não existe pecado debaixo da linha do equador? Boletim IBCCRIM, São Paulo, n. 173, abr. 2007.

; MOURA, Maria Thereza Rocha de Assis; PITOMBO, Cleonice Valentim. As

anotações sobre o Seminário Internacional: a implementação do Estatuto de Roma no Direito Interno e outras questões de direito penal internacional. Boletim IBCCRIM, São Paulo, v. 139, jun. 2004. 